\title{
ANNOTATED LIST OF ORCHIDACEAE TYPES OF THE BENNETT COLLECTION AT THE FORESTRY HERBARIUM MOL
}

\author{
Delsy Trujillo
}

\author{
Research Associate, Herbario MOL, Facultad de Ciencias Forestales, Universidad Nacional Agraria \\ La Molina. Av. La Universidad s/n. La Molina. Apartado 12-056 - Lima, Perú \\ delsytrujillo@lamolina.edu.pe
}

\begin{abstract}
An annotated list of the original material of 183 Orchidaceae species of the Bennett's collection at the Forestry herbarium of the University Agraria La Molina is presented. The annotated list includes collection data, information on locations of the type material in other herbaria and the currently accepted name for each species. Seventy two lectotypes are designated; and a new species and a new combination are validated under the current code of nomenclature (International Code of Nomenclature -Melbourne Code).

Resumen. Se presenta una lista anotada del material original de 183 especies de Orchidaceae de la colección Bennett en el Herbario Forestal de la Universidad Agraria La Molina. La lista anotada incluye los datos de colecta de los especímenes, información sobre la ubicación del material tipo en otros herbarios y el nombre actual aceptado para cada especie. Setenta y dos lectotipos son designados, y una nueva especie y una nueva combinación son validadas de acuerdo al código de nomenclatura vigente (Código Internacional de Nomenclatura-Código de Melbourne).
\end{abstract}

KeY words: Orchidaceae, types, Peru, herbarium MOL

Introduction. During the past three decades, David E. Bennett Jr. (1923-2009) was one of the major contributors to the knowledge of the Peruvian orchids. He was born in the United States, and lived in Peru since 1946. He married a Peruvian, Aurora Pastorelli, with whom he shared his interest in orchids and collected numerous orchids during their trips around Peru. He was an agricultural engineer. Before he became interested in orchids, he worked initially in Peru as a Manager of an American Company that manufactured agrochemical products.

Bennett kept a diverse living orchid collection in Lima. He gathered plants from various collectors (orchid hobbyists and botanists), and from his own field trips. Bennett asked different artists to prepare black and white line drawings, as well as color drawings from his living specimens. By 2009, he had amassed around 1600 orchid illustrations. He also had his own personal collection (Herbarium Bennettianum) of both flowers in spirit and pressed specimens prepared mainly from his living collection.

Bennett was co-author of various orchid publications mainly based on specimens from his own collection. Starting in 1989, he published line drawings and descriptions of more than 900 Peruvian species; including 259 new ones. The most remarkable publications were the four volumes of his selfpublished book Icones Orchidacearum Peruviarum that he co-authored with Eric A. Christenson (19562011).

According to Bennett's publications, many herbarium specimens (including types) from which he based his orchid descriptions were deposited at AMES, FLAS, K, USM, MO, MOL and NY. However; many of them were not located in any of those herbaria (Dalström 2012, Dalström and Ruíz-Pérez 2012, Roque \& León 2007). Regarding of the specimens cited by him at USM, they indeed were initially deposited at that herbarium. However, Bennett later asked that the specimens be returned to him (Christenson 2008). Nonetheless, a few remain at USM.

In 2001, Bennett transferred all his collection to the forestry herbarium of the University Agraria La Molina - MOL. This set comprises 1677 herbarium specimens, and 1209 specimens preserved in spirit. However, the few botanists that have checked the Bennett collection at MOL could not confirm that there were many type specimens there (Roque \& 
León 2007). Some of the challenges to relocate those specimens have been the disappearance of Bennett's Accession Book and of a checklist of the specimens donated to MOL. Additionally; the specimens in spirit only had the collector (abbreviation) and number or plate number in the jar; but not the species name or any other data. Moreover, he rarely updated the species determination on the herbarium specimens or wrote a note to indicate if the specimen was a type. It is noteworthy that in the herbarium specimens, the collection data were written on folders, instead of labels glued to the mounting sheets.

The importance of type specimens as permanent vouchers for the application of botanical names is completely recognized today, and the numerous initiatives of herbaria to make type specimens information available on the Internet underline the importance of types. Curatorial work of the Bennett collection at MOL was started in the middle of 2010. Among others objectives, the work was aimed at evaluating and preparing a list of types kept in the collection, and creating a digital gallery of the type specimens, including the flowers in spirit.

Evaluation of the type collection follows the current code of nomenclature (ICN-Melbourne Code, 2012). As mentioned above, sorting material by collecting number revealed several problems. Challenges for the evaluation included: a) discordance date between the protologue and collecting data written on the folders (labels), b) more than one "duplicate" of the type specimen, with different dates of preparation; and c) the collecting number of some specimens have additionally suffix numbers (e.g. Bennett 3154-1, Bennett 3154-2) not cited in the protologue.

A search at his home for his accession book or a digital file proved to be unsuccessful. However, two additional sources of information were found: a table of records with the illustrated specimens indicating the plate number, and field work reports of Marco León M et al.. (one of the botanists who provided specimens to Bennett). These sources of information together with a careful revision of the collecting data and publications led to understand the way he prepared specimens, managed his collection, and cited the specimens in his manuscripts.

Bennett used an Accession Book and, later, a digital file or files (he annotated many labels: "see Acc. Book" or "see Computer" for additional collection data) where he copied the collecting data of the specimen either collected by himself or by another person. If there was a living specimen it was labeled with his number, and then placed in cultivation in his nursery. On flowering, a plant was illustrated and a herbarium specimen was prepared either from a complete plant or from some flowers. Usually only a dissected flower was preserved in spirit, but, exceptionally, he also preserved a complete plant in spirit (particularly in the case of miniature orchids). It also seems that he sometimes forgot to preserve either pressed or spirit specimens; and therefore this would explain why some holotypes are considered "lost", e.g. Cochlioda chasei D.E. Benn. \& Christenson (Dalström 2012).

When Bennett published a new species, he cited a collecting date for the type that actually refers the date when the plant was collected in the field (according to his lost Accession Book); but do not always refers the date when the types were prepared from cultivated specimens.

In many cases, he prepared more than one herbarium or spirit specimen, but on different dates since the plant in cultivation flowered many times. These apparent duplicates were labeled with the same number of his earlier type collection. Thus, he not only neglected to indicate in the publication the date of the preparation ("collection") of the holotype; he also failed to designate which of the prepared specimens was the holotype. Sometimes, he considered these "duplicates" as isotypes, although they were prepared on different dates than the holotype.

In his nursery, Bennett also had clones of some specimens; the result of the vegetative propagation of the original plant. To differentiate these clones he added a suffix number after the collection number. Thus, herbarium and/or spirit specimens were prepared from the clones. Here again; when he described a new species, he failed to indicate which specimen was chosen as the type, as well its preparation date. Sometimes, he indicated the suffix number in the illustration voucher but not when designating the holotypes or paratypes.

Bennett also used this system of "suffixes" to label two or more plants of a species gathered in a given 
time or when another collector provided him with more than one plant of a species; for instance, the type material of Stenia jarae D.E. Benn. consists of Bennett 4711-3 (holotype), Bennett 4711-1 (paratype) and Bennett 4711-2 (paratype). These specimens were originally collected by E. Jara at different localities; therefore, in this case the suffix numbers are not clones or duplicates.

It is unknown why he did not deposit some specimens in the herbaria that he indicated in the protologue. It seems that he did not deposit all his type specimens at USM (before asking for their return). For instance some specimens of Moises Cavero were kept in newspaper sheets until the curatorial work began at MOL. Also, some specimens that according to the protologue were deposited at USM have been located at NY. Since the status of the material of the collection at MOL is unclear in terms of nomenclatural types, that is whether they represent holotypes, isotypes or paratypes; this annotated list presents an evaluation of Bennett's specimens at this herbarium.

Materials and methods. For this evaluation, other Bennett's specimens at AMES, FLAS, K, NY and SEL, were searched via personal communication with the respective curators. Specimens at MO were accessed through Tropicos.org. The author looked for the specimens at USM herself. If no holotype was located, a lectotype was designated; following the current code of nomenclature (ICN-Melbourne Code, McNeill et al. 2012).

Additionally, new species or combinations based on a Bennett specimen are validated here when they were not validly published under the criteria of the International Code of Nomenclature for algae, fungi, and plants. Finally, photographs of holotypes, lectotypes and a neotype of (only) spirit preparations are provided as Supplementary Material.

\footnotetext{
Alphabetical list of type specimens and other original material. In the Bennett collection at MOL, there are original material of 183 orchid species described based on Bennett's specimens (species included here are those published until August 2013 by different authors besides David Bennett and co-authors). The total number of type specimens in the Bennett Collection is 239; of which 85 are holotypes, 35 isotypes, 9
}

paratypes, 63 lectotypes, 46 isolectotypes (26 are from Sobralia ruparupaensis) and 1 neotype. Many of the type specimens are only in spirit preparations (probably Bennett forgot to prepare pressed specimens after the illustration of the specimen), which consist of dissected flowers.

Nine Bennett specimens deposited at herbaria other than MOL are also designated here as lectotypes (species described by Bennett and co-authors).

In the present manuscript the information is presented as follow:

For each species listed below, the full name of the species is indicated, including the publication where it was described. The complete type specimen designation follows as cited in the protologue; i.e., exact locality, altitude and date of collection and/or preparation of the specimen and the repository herbaria of the type specimen (s). Corrections or additional information for the protologue are added in square brackets "[ ]", for instance correcting elevation data or adding the date of preparation of the specimen (that was not cited in the protologue). There are also annotations concerning the depository herbaria. If the protologue indicates that the specimen was deposited at Herb. Bennettianum and is now at MOL, the following phrase is used: "originally deposited at .., now at..". But if the protologue indicates that the type specimen was deposited in a herbarium different from Herb Bennettianum and is now at MOL, the following phrase is used: "according to the protologue at ..., now deposited at...".

For those species where new types (i.e., lectotype) were designated, the locality data and date of preparation is provided (when those data are provided on the label of the specimen), followed by the lectotypification.

The currently accepted name for each species, if different from that published one, is also included. These are listed at the end of each section and preceded by either "Basionym of" or "Synonym of" followed by its place of publication.

Finally, comments concerning the original material found at MOL and other herbaria and about the lectotype designation are provided.

Checklists of the lectotypes designated in the manuscript, and the type specimens of the Bennett Collection at MOL, are provided in Tables 1 and 2. 


\section{ANNOTATED LIST}

Ackermania hajekii D.E. Benn. \& Christenson, Icon. Orchid. Peruv.: t. 602. 2001.

TYPE: Peru, Pasco, Oxapampa, between Villa Rica and Cacazu, ca. $1400 \mathrm{~m}$, [between Cacazu and Puerto Bermudez, ca $1200 \mathrm{~m}$, in error], Hort. C. Hajek, flowering in cultivation 10 Mar 1999 [9 Mar 1999, in error], Bennett 7890 . Holotype: originally deposited at Herb. Bennettianum, now at MOL.

Basionym of: Benzingia hajekii (D.E.Benn. \& Christenson) Dressler, Lankesteriana 9: 527. 2010.

Bennett 7890 found in the Bennett collection at MOL was collected between Villa Rica and Cacazu at $1400 \mathrm{~m}$ and prepared on March 10, 1999; and not between Cacazu and Puerto Bermudez at $1200 \mathrm{~m}$ and prepared on March 9, 1999, as was cited in the protologue. However, this specimen has a Bennett's annotation indicating that it is the holotype of Ackermania hajekii. Therefore, the collection data cited in the protologue is erroneous and here is corrected.

Ackermania jarae D.E.Benn. \& Christenson, Brittonia 47: 182. 1995.

TYPE: Peru, Huanuco, Leoncio Prado, above Cueva de las Pavas, 1200 m, 17 Apr 94, E.Jara P.ex D. Bennett 6578. Holotype NY; Isotype: according to the protologue at USM, now deposited at MOL[-spirit]. Paratype: Peru, Huanuco, Leoncio Prado, Cueva de las Pavas, 1000 m, 6 Feb 1987, E. Jara P. ex D. Bennett 4215. Paratype: MO?.

Basionym of: Benzingia jarae (D.E.Benn. \& Christenson) Dressler, Lankesteriana 9: 527. 2010.

Two additional herbarium specimens (only flowers) of E.Jara P. ex D. Bennett 6578 were found in the Bennett collection at MOL; they were prepared on April 26, 1995 and June 14, 1995 respectively. The second specimen is not part of the original material because it was prepared after June 2, 1995; the date of species publication.

A pressed specimen with the same number that the Paratype; i. e., Bennett 4215 was also found in the Bennett Collection. However it has a different date of preparation and elevation: February 16, 1988 and 950 $\mathrm{m}$.
Ada peruviana D.E.Benn. \& Christenson, Icon. Orchid. Peruv.: t. 603. 2001.

TYPE: Peru, Junin, Chanchamayo, Pichinaki, San Alejandro sector, $1700 \mathrm{~m}, O$. del Castillo ex Bennett 7770. Holotype: originally deposited at Herb. Bennettianum, now at MOL.

Basionym of: Brassia davidii Senghas, Die Orchideen 2801. 2001.

Ada rolandoi D.E. Benn. \& Christenson, Brittonia 46: 228. 1994.

TYPE: Peru, Pasco, Oxapampa, Villarica, in the Yanachaga-Chemellin National Park, Jul 1991, I. Rolando, ex Bennett 5304. Holotype: USM, lost. Leстотуре here designated: Peru, Pasco, Oxapampa, in mountain above Villarica, 1800m, 4 Nov 1991, J. Campoverde ex Bennett 5304 (MOL).

Basionym of: Brassia rolandoi (D.E.Benn. \& Christenson) M.W.Chase, Phytotaxa 20: 28. 2011.

The holotype was not found in any Peruvian herbarium. The original material of Ada rolandoi found in the Bennett collection at MOL consists of two specimens of Bennett 5304: one in spirit and one pressed. The specimen in spirit consists of an intact flower and has no date of preparation. The pressed specimen comprises a plant with an inflorescence (four flowers) prepared on November 4, 1991; however the date disagrees with that given in the protologue. The data written on the label also indicates that the specimen was collected by J. Campoverde (not by I. Rolando as was cited in the protologue).

As there is no holotype, the lectotype is designated here from among the specimens that comprise the original material (ICN. Art. 9.2, 9.12). The specimen chosen as lectotype is the most complete pressed specimen.

Brassia aurorae D.E.Benn., Lindleyana 7: 87. 1992.

TYPE: Peru, Department of Pasco, Province of Pasco, Yuncan, 1900 m, 9 May 1987, D. \& A. Bennett 3811. Holotype: USM, lost. LectotyPE here designated: Peru, [Department of Pasco, Province of Pasco], above Yuncan, 1950 m. 1 Mar 1989, D. Bennett 3811 (USM 277244). 
The holotype was not found in any Peruvian herbarium. The original material comprises five pressed specimens of Bennett 3811; three at USM and two at MOL. However, the locality data and dates of preparation of these specimens disagree with that given in the protologue. At USM, one specimen (accession number: 277244) has three labels indicating different collecting data. Two labels have the Bennett handwriting indicating that the specimen was prepared on March 1, 1989; in one label is also written: "above Yuncan, $1950 \mathrm{~m}$ " and in the other: "Brassia nov sp". The third label on the herbarium sheet of this specimen, made at FLAS, indicates this collection data: "Pasco, Yaupi alto, 1900 m, January 6 1988"; however this is not the original label of this specimen, but corresponds to the others specimens at USM.

The labels of other two specimens at USM (accession number: 168460 and 277243) indicate that the specimens were collected in Yaupi Alto at $1900 \mathrm{~m}$ and prepared on January 6, 1988. One specimen has two labels: one made by Bennett and the other by FLAS. The other specimen has a single label, made by Bennett.

The two specimens found at MOL were prepared on June 12, 1988 and March 1, 1989; only the first specimen has locality data:" Pasco, above Yaupi, 1900 m".

In absence of the holotype, a lectotype is designated here (ICN. Art. 9.2). The specimen at USM with the Accession Number "277244" is here chosen as lectotype; which consist of a pressed plant with an inflorescence that has Bennett's handwriting notes indicating “Brassia nov sp.” (ICN. Art. 9.12, 9A.3).

Brassia pascoensis D.E.Benn. \& Christenson, Icon. Orchid. Peruv.: t. 608. 2001.

TYPE: Peru, Pasco, Villarica, below Cacazu near Los Angeles bridge, $780 \mathrm{~m}$, August 1988, Bennett et al. 4373. Holotype: Herb. Bennettianum [now at MOL], lost. Lectotype here designated: Peru, Dept. Pasco, Prov. Oxapampa, below Cacazu, 16 Jun 1989 D. Bennett \& A. Bennett 4373 (MOL).

The holotype was not found in the Bennett collection at MOL.

Living specimens of Bennett 4373 were cultivated in Lima by David Bennett and at the University of Florida. Two herbarium specimens prepared from the living specimen cultivated in Lima were found in the Bennett Collection at MOL. They were prepared on different dates: June 16, 1989 and March 24, 1994 (the specimen prepared on this date has not locality information). The dates of preparation of both specimens disagree with that given in the protologue; however they represent the original material. The specimen chosen as lectotype is the most complete specimen that has locality information on the label (ICN. Art. 9.12).

The pressed specimens prepared from the living plant cultivated at the University of Florida are conserved at FLAS (x2) and at USM (x1).

Brassia transamazonica D.E.Benn. \& Christenson, Icon. Orchid. Peruv.: t. 609. 2001.

TYPE: Peru, Pasco, Oxapampa, Puerto Bermudez, near Pichis River, 250 m, 10 Jan 1991, O. del Castillo ex Bennett 4937. Holotype: Herb. Bennettianum [now at MOL], lost. Lectotype here designated: Peru, without locality data [probably same as in the protologue] ex Bennett 4937 (MOL-spirit; Fig. S1).

The holotype was not found in the Bennett collection at MOL. The original material of Brassia transamazonica found in the Bennett collection at MOL consists of three specimens of Bennett 4937: one in spirit and two pressed. The specimen in spirit consists of three flowers (one dissected) that agree with the illustration of the original publication. The two pressed specimens (just inflorescence) were prepared on different dates: July 9, 1991 and July 20, 1992, respectively. However, none of them agrees with the date of preparation given in the protologue. The specimen chosen as lectotype is the specimen in spirit, which was probably used for the species illustration (ICN. Art. 9.12, 9A.3).

Buesiella suarezii D.E.Benn. \& Christenson, Icon. Orchid. Peruv.: t. 611. 2001.

TYPE: Peru, Huancavelica, Tayacaja, Huachocolpa district, 2800-3000, May 1999, R. Suarez \& G. Alegría ex Bennett 7911. Holotype: Herb. Bennettianum [now at MOL] lost [see below]. LECTOTYPE here designated: Peru, without locality data [probably same as in the protologue] ex Bennett 7911 (MOL-spirit; Fig. 2).

Comment. - The holotype was not found at MOL. 
The original material of Buesiella suarezii found in the Bennett Collection at MOL comprises two specimens of Bennett 7911; one pressed and one in spirit. The pressed specimen (sterile) was prepared on June 12, 1999; however the date disagrees with that given on the protologue. The specimen in spirit consists of part of an inflorescence with some flowers (two dissected) that agree with the illustration of the original publication. The illustration was prepared on June 9, 1999; probably the date that specimen in spirit was prepared.

In absence of the holotype, a lectotype is designated here from among the specimens that comprise the original material (ICN. Art. 9.2, 9.12). The specimen chosen is the specimen in spirit.

Bulbophyllum machupicchuense D.E.Benn. \& Christenson, Icon. Orchid. Peruv.: t. 612. 2001.

TYPE: Peru, Cusco, Urubamba, km 87 along the railroad line to Machu Picchu, 2500 m, 29 Jan 1999 , León \& Collantes 2854. Holotype: originally deposited at Herb. Bennettianum, now at MOL[-spirit] (Fig. 3); Isotype: MOL, not found.

León \& Collantes 2854 in spirit was found in the Bennett Collection at MOL, but no pressed preparation was located. The (few) flowers in the spirit collection agree with the illustration of the protologue, and here it is therefore regarded as the holotype.

\section{Campylocentrum huebnerioides D.E.Benn. \&} Christenson, Icon. Orchid. Peruv.: t. 408. 1998.

TYPE: Peru, Junin, Chanchamayo, 1600 m, 18 Apr 1996 [1966, in error], O. del Castillo ex Bennett 7503. Holotype: USM, lost. LeCtotype here designated: Peru, Junin, Chanchamayo, 2700 m, 22 Apr 1996, O. del Castillo ex Bennett 7503 (MOL).

The holotype was not found at USM. The protologue erroneously indicates that the type specimen was collected on 1966. del Castillo provided specimens to David Bennett in the 1990s and not in the 1960s.

Two preparations of Bennett 7503 are in the Bennett Collection at MOL: one pressed and one in spirit. The data written on the label of the herbarium specimen indicates that the specimen was collected at $2700 \mathrm{~m}$ of elevation and prepared on April 22, 1996. The date of preparation (day and month) and elevation disagree with that given on the protologue. The specimen in spirit consists of an inflorescence with intact flowers, but it does not have date of preparation.

In absence of the holotype, a lectotype is designated here (ICN. Art. 9.2). The specimen chosen as lectotype is the most complete (pressed) specimen.

Catasetum adremedium D.E.Benn. \& Christenson, Icon. Orchid. Peruv.: t. 409. 1998.

TYPE: Peru, Loreto, Ucayali, km 84 along road between Tingo Maria and Pucallpa, ca. 400 m, 9 Sept 1991, E. Jara P. ex Bennett 5295. Holotype: AMES, lost. Leстотуре here designated: Peru, Loreto: Ucayali, km 84 Tingo Maria toward Pucallpa, $400 \mathrm{~m}$, 24 Feb 1992, E. Jara P. ex Bennett 5295-15 (MOL, part in spirit).

The holotype was not found at AMES (G. A. Romero, pers. comm.). The specimen found in the Bennett Collection at MOL has the suffix " 15 "; i.e. Bennett 5295-15 and a different date of preparation; however it represents the original material and it is here chosen as lectotype (ICN. Art. 9.12).

Catasetum cotylicheilum D.E.Benn. \& Christenson, Icon. Orchid. Peruv.: t. 410. 1998.

TYPE: Peru, Huanuco, Leoncio Prado, 20 kms from Tingo Maria along road to Pucallpa in abandoned rubber grove, 1 Apr 1988, ca. 900 m, E. Jara P. ex Bennett 4306. Holotype: USM, lost. LectotyPe here designated: Peru, Huanuco, Leoncio Prado 20 $\mathrm{km}$ from Tingo Maria, towards Pucallpa in an old rubber plantation, $600 \mathrm{~m}$, Bennett 4306-14 (MOLspirit; Fig. 4).

The holotype of Catasetum cotylicheilum was not found in any Peruvian herbarium. Four specimens of Bennett 4306 with different suffixes are in the Bennett Collection at MOL: Bennett 4306-14 (one pressed and two in spirit) and Bennett 4306-16 (pressed with part in spirit). Only the pressed specimen of Bennett 4306-14 has collection data on the label. The specimen chosen here as lectotype is Bennett 4306-14 in spirit made up of two flowers (one dissected) which were probably used for the species illustration (ICN. Art. 9.12, 9A.3). 
Because it is uncertain if the other two specimens of Bennett 4306-14 were prepared on the same date as the lectotype, they are not designated here as isolectotypes.

Catasetum purusense D.E.Benn. \& Christenson, Icon. Orchid. Peruv.: t. 417. 1998.

TYPE: Peru, Ucayali, Coronel Portillo, Puerto Esperanza, along Rio Purus, 200 m, 12 Nov 1997, J. Graham and J. Schunke V. 310 ex Bennett 7811. Holotype: USM, lost. LectotyPE here designated: Peru, Ucayali, Coronel Portillo, Puerto Esperanza, along Rio Purus, 200-250 m, 16 Dec 1997, J. Graham and J. Schunke V. sn ex Bennett 7811-1 (MOL).

The holotype of Catasetum purusense was not found at USM.

James Graham collected a living plant (sterile) of this species and gave it to David Bennett (without a collection number) on November 1997 (J. Graham, pers. comm.). David Bennett incorporated this living specimen into his nursery as Bennett 7811 . When the plant bloomed, it was illustrated (on December $15,1997)$ and pressed and in spirit specimens were prepared.

The original material of Catasetum purusense found in the Bennett collection at MOL includes two specimens in spirit and one pressed. One specimen in spirit consists of two flowers and the other of three flowers. Both specimens in spirit are labeled as Bennett 7811 . They do not have date of preparation but agree with the description of the species. The pressed specimen is labeled as: J. Graham \& J. Schunke s.n. ex Bennett 7811-1, it consists of a pressed inflorescence prepared on December 16, 1997.

In absence of the holotype, a lectotype is designated here from among the specimens that comprise the original material (ICN. Art. 9.12). The specimen here chosen as lectotype is the most complete herbarium specimen.

Chaubardiella delcastilloi D.E.Benn. \& Christenson, Icon. Orchid. Peruv.: t. 423. 1998.

TYPE: Peru, Cusco, Quillabamba, Quirimbiri district, San Pantuari, 26 Sept 1995, 900 m, O. del Castillo ex Bennett 7309. Holotype: according to the protologue at USM-spirit, now deposited at MOL-spirit (Fig. 5).

The dissected flower in spirit found in the Bennett collection at MOL agrees with the illustration of the original publication.

Chaubardiella serrulata D.E.Benn. \& Christenson, Icon. Orchid. Peruv.: t. 424. 1998.

TYPE: Peru, Cuzco, Quillabamba, Quirimbiri District, San Pantuari (a native community), 909 m, 26 Sept 1995, O. del Castillo ex Bennett 7307. Holotype: according to the protologue at USM, now deposited at MOL-[spirit] (Fig. 6).

Bennett 7307 in spirit was found in the Bennett Collection at MOL; however, a pressed preparation was not located in any Peruvian herbarium. The specimen is a dissected flower that agrees with the illustration of the original publication. Therefore the specimen in spirit is the holotype.

Chondrorhyncha plicata D.E.Benn. \& Christenson, Brittonia 46: 24. 1994.

TYPE: Peru, Junin, Kivinaki, N margin of Rio Perene, 1700 m, 26 Mar 1992, O. del Castillo s.n. ex D. Bennett 5507. Holotype: according to the protologue at USM, now deposited at MOL[-spirit] (Fig. 7). Paratype: Peru, Dept. Piura, Prov. Ayabaca, Ruinas de Aypate, below summit, $1950 \mathrm{~m}, J$. Campoverde ex D. Bennett 5723. Paratype: NY? [see below].

Basionym of: Chondroscaphe plicata (D.E.Benn. \& Christenson) Dressler, Orquideologia 22: 22. 2001.

Bennett 5507 in spirit was found in the Bennett Collection at MOL; however, a pressed preparation was not located in any Peruvian herbarium. The spirit specimen is a dissected flower that agrees with the illustration of the original publication. Therefore the specimen in spirit is the holotype.

Bennett \& Christenson (1994) designated the specimen Bennett 5723 deposited at NY as the paratype of Chondrorhyncha plicata. However; a year later, the same authors cited the same collection -but a specimen deposited at USM as Chondrorhyncha viridisepala Senghas (Icon. Orchid. Peruv: t. 219, 1995). The specimen that is conserved at NY has the suffix number "4" (Bennett 5723-4, paratype?). No specimen of Bennett 5723 was found at USM. However, Bennett 5723-1 was found in the Bennett's spirit collection at MOL. Further research is necessary 
in order to know the true identities of Bennett 5723-4 and Bennett 5723-1.

Cycnoches christensonii D.E. Benn., Icon. Orchid. Peruv.: t. 430. 1998.

TYPE: Peru, Huanuco, Leoncio Prado, Bejucal, 1400 $\mathrm{m}$, E. Jara P. ex Bennett 7351. Holotype: according to the protologue at USM, now deposited at MOL, part in spirit; [Isotypes: MOL (x3)].

Cycnoches cooperi subsp ayacuchoensis D.E. Benn. \& Christenson, Icon. Orchid. Peruv.: t. 431. 1998.

TYPE: Peru, Ayacucho, San Miguel, Ayna, sector Macheate, 1365 m, 26 Sept 1995, O. del Castillo ex Bennett 7275. Holotype: USM, lost. LeCTOTYPE here designated: Peru, Ayacucho, San Miguel, Ayna, Macheate, 1365 m, 9 Feb 1997, O. del Castillo ex Bennett 7275 (MOL).

The holotype of Cycnoches cooperi subsp ayacuchoensis was not located in any Peruvian herbarium. However, five specimens of Bennett 7275 are in the Bennett Collection at MOL: three pressed and two in spirit. They represent the original material. Two specimens have pistillate flowers: one in spirit and one pressed (the latter prepared on April 13, 1996). And three specimens have staminate flowers: one in spirit and two pressed specimens with different dates of preparation: February 9, 1997 and June 10, 1998 (this specimen consists of two sheets; and does not have locality data on the label). None of the specimens found at the Bennett Collection has the same date of preparation given in the protologue nor have an annotation that indicates that it is the holotype. However, in two specimens (one staminate and one pistillated) David Bennett wrote: "sp nov". Therefore, the specimen here chosen as lectotype is the one with a staminate flower with the Bennett's annotation (ICN. Art. 9.12, 9A.3).

\section{Cycnoches farnsworthianum D.E.Benn.}

$\&$ Christenson, Icon. Orchid. Peruv.: t. 619. 2001.

TYPE: Peru, Ucayali, Purus, Rio Curanjo, vicinity of Colombiana, native community, $10^{\circ} 03^{\prime} 66^{\prime \prime} \mathrm{S}$, 7106'04'W, 300-350 m [250 m, in error], $24 \mathrm{Feb}$ 2000, J. Graham (\#1110) \& J. Schunke ex Bennett 7957.
Holotype: originally deposited at Herb. Bennettianum, now at MOL.

An unmounted pressed specimen of Cycnoches was found in the Bennett Collection at MOL. It was between newspaper sheets, without a label but with two annotations on the sheet: "1110" and "unicate". During the preparation of the present manuscript; the specimen was shown to James Graham (the original collector of the type specimen); and he recognized the specimen and the handwritten notes on the sheet (that were written by J. Schunke Vigo, the co-collector of the specimen). A careful review of the specimen and the protologue, together with the information provided by J. Graham, confirm that this specimen is the holotype of Cycnoches farnsworthianum.

The protologue indicates that the type specimen was collected at $250 \mathrm{~m}$; however, the collection data provided by J. Graham indicates that it was found at $300-350 \mathrm{~m}$. Therefore, the elevation data in the protologue is erroneous and is here corrected.

Cycnoches quatuorcristis D.E.Benn., Lindleyana 7: 83. 1992.

TYPE: Peru, Department of Junin, Province of Satipo, District of Paratushiali, $700 \mathrm{~m}$, Feb 1990, $R$. Fernandez 23, [89368, in error], Holotype USM, lost [See below]. Lectotype here designated: Peru, Department of Junin, Province of Satipo, District of Paratushiali, 700 m, 14 Feb 1990, R. Fernandez 23, ex Bennett 4568 (USM 167755).

Bennett stated in the original publication: "Male flowers of the type specimen are at FLAS under Bennett 4568" (page 87). This specimen was found at FLAS!; it was prepared by Mark Whitten after flowering in cultivation on January 2, 1991 (the label says: "Plant collected in 1990 by Ricardo Fernandez and exported by David E. Bennett Jr as Bennett 4568, coll. Mark Whitten 3834"). But the preparation date of this specimen disagrees with that given in the type designation in the protologue.

In the Bennett collection at MOL there is a specimen of Bennett 4568 in spirit. It consists of two dissected staminate flowers that agree with the species description. But it has no collection data or type's annotation on the label.

There are two specimens with staminate flowers 


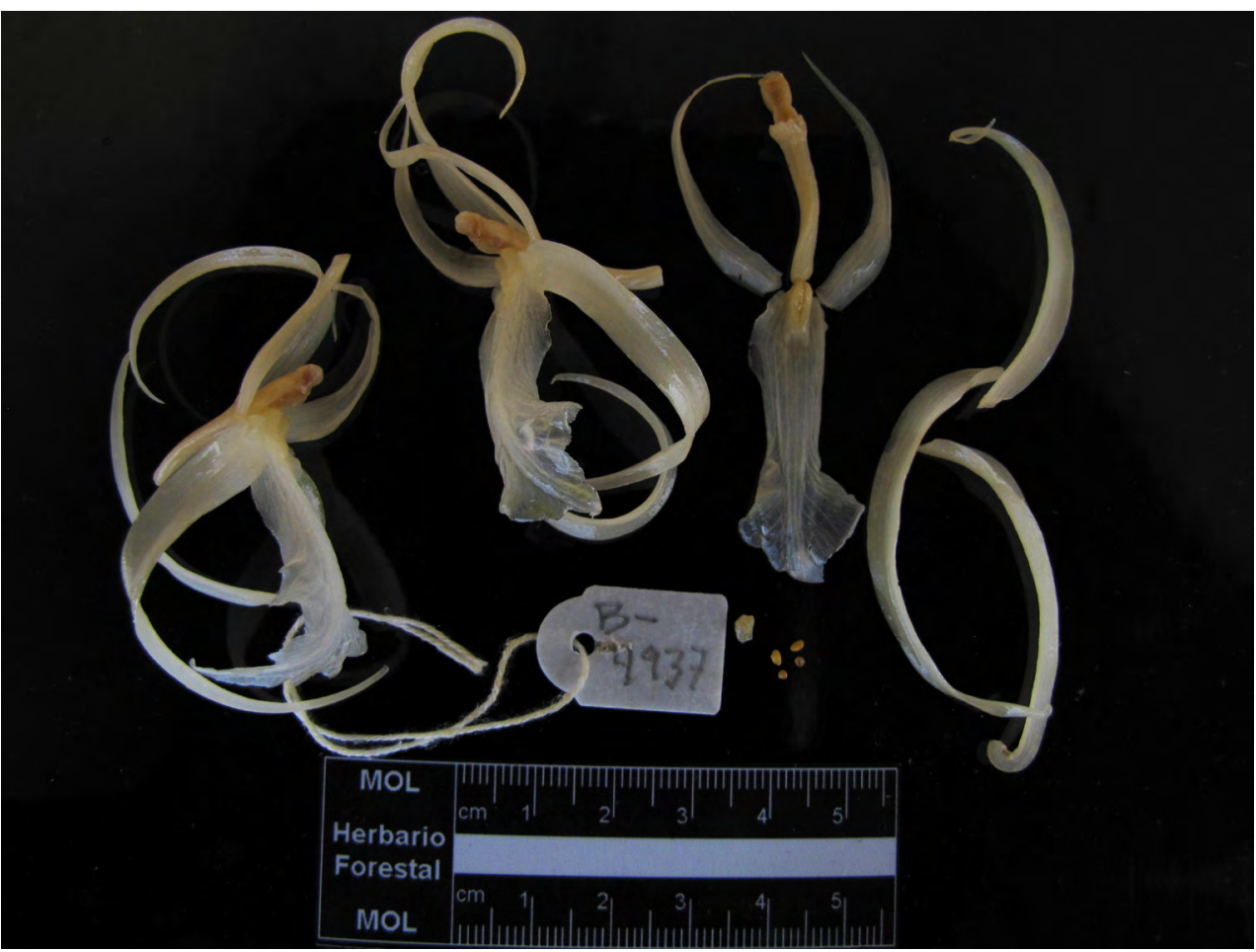

Figure 1. Brassia transamazonica D.E.Benn. \& Christenson. Lectotype at MOL (Bennett 4937 in spirit). Photo: D. Trujillo.

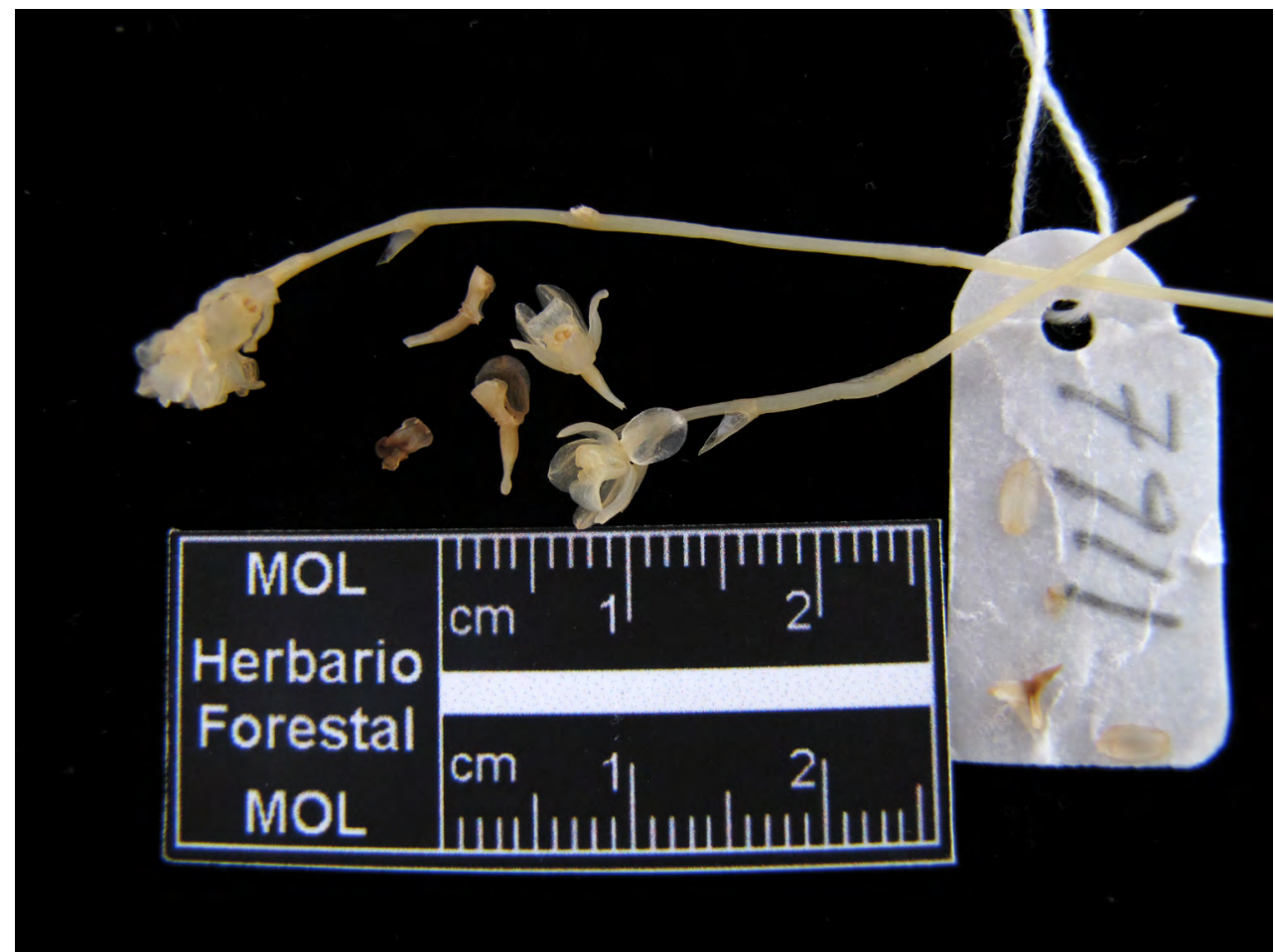

Figure 2. Buesiella suarezii D.E.Benn. \& Christenson. Lectotype at MOL (Bennett 7911 in spirit). Photo: D. Trujillo. 




Figure 3. Bulbophyllum machupicchuense D.E.Benn. \& Christenson. Holotype at MOL (M. León 2854 in spirit). Photo: D. Trujillo.

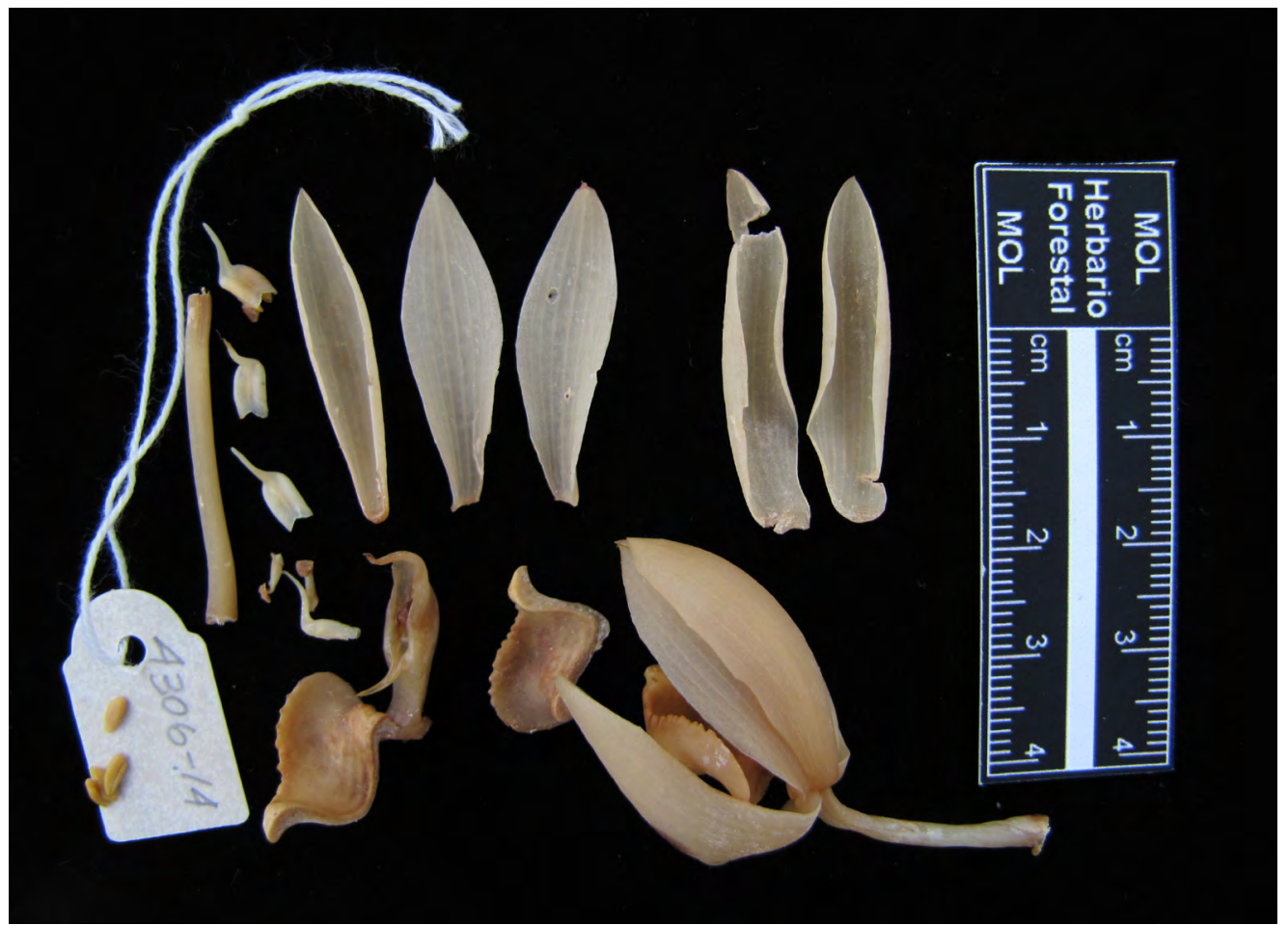

FiguRE 4. Catasetum cotylicheilum D.E.Benn. \& Christenson. Lectotype at MOL (Bennett 4306-14 in spirit). Photo: D. Trujillo. LANKESTERIANA 14(1), April 2014. (C) Universidad de Costa Rica, 2014. 


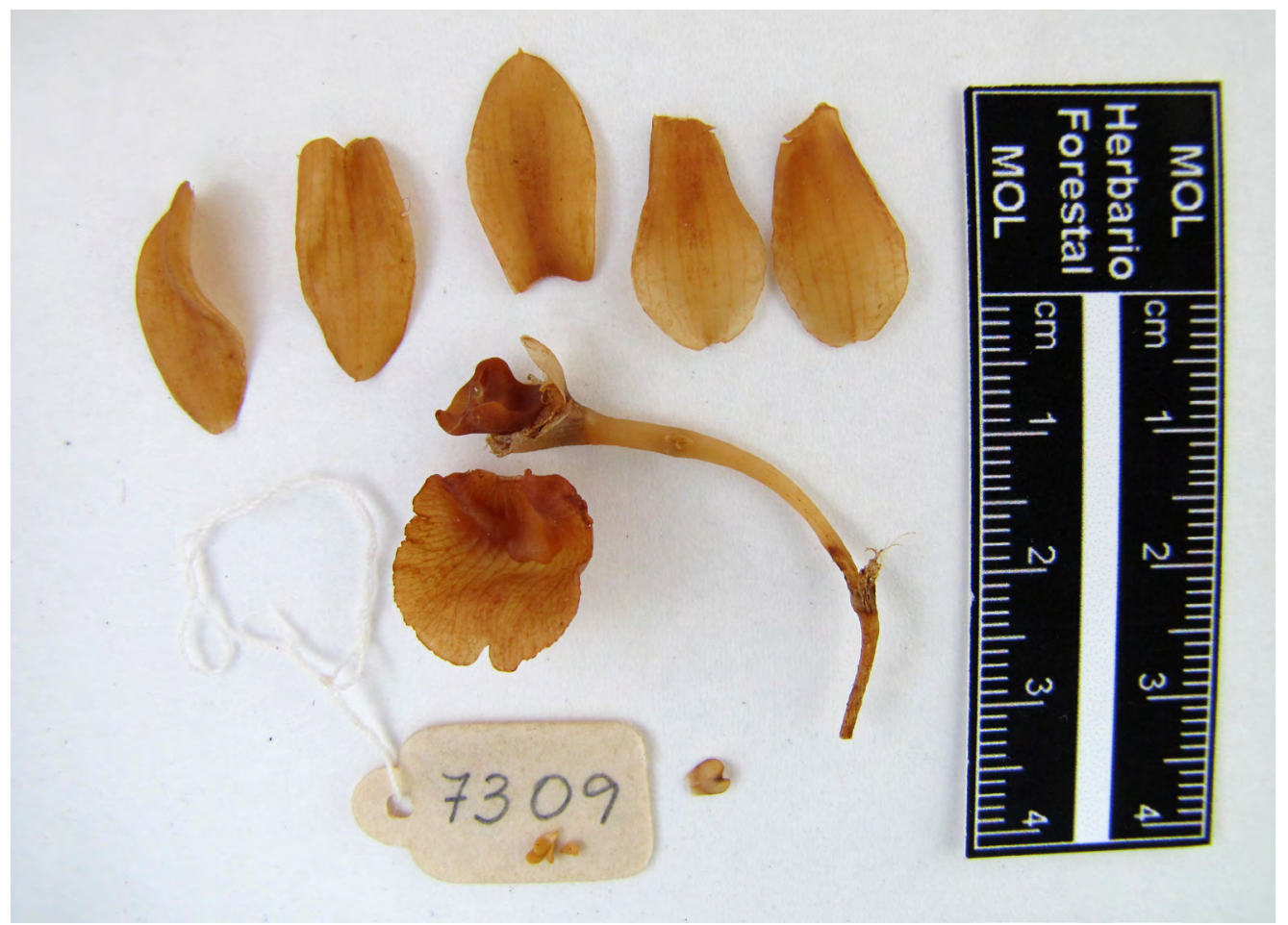

FiguRE 5. Chaubardiella delcastilloi D.E.Benn. \& Christenson. Holotype at MOL (Bennett 7309 in spirit). Photo: D. Trujillo.

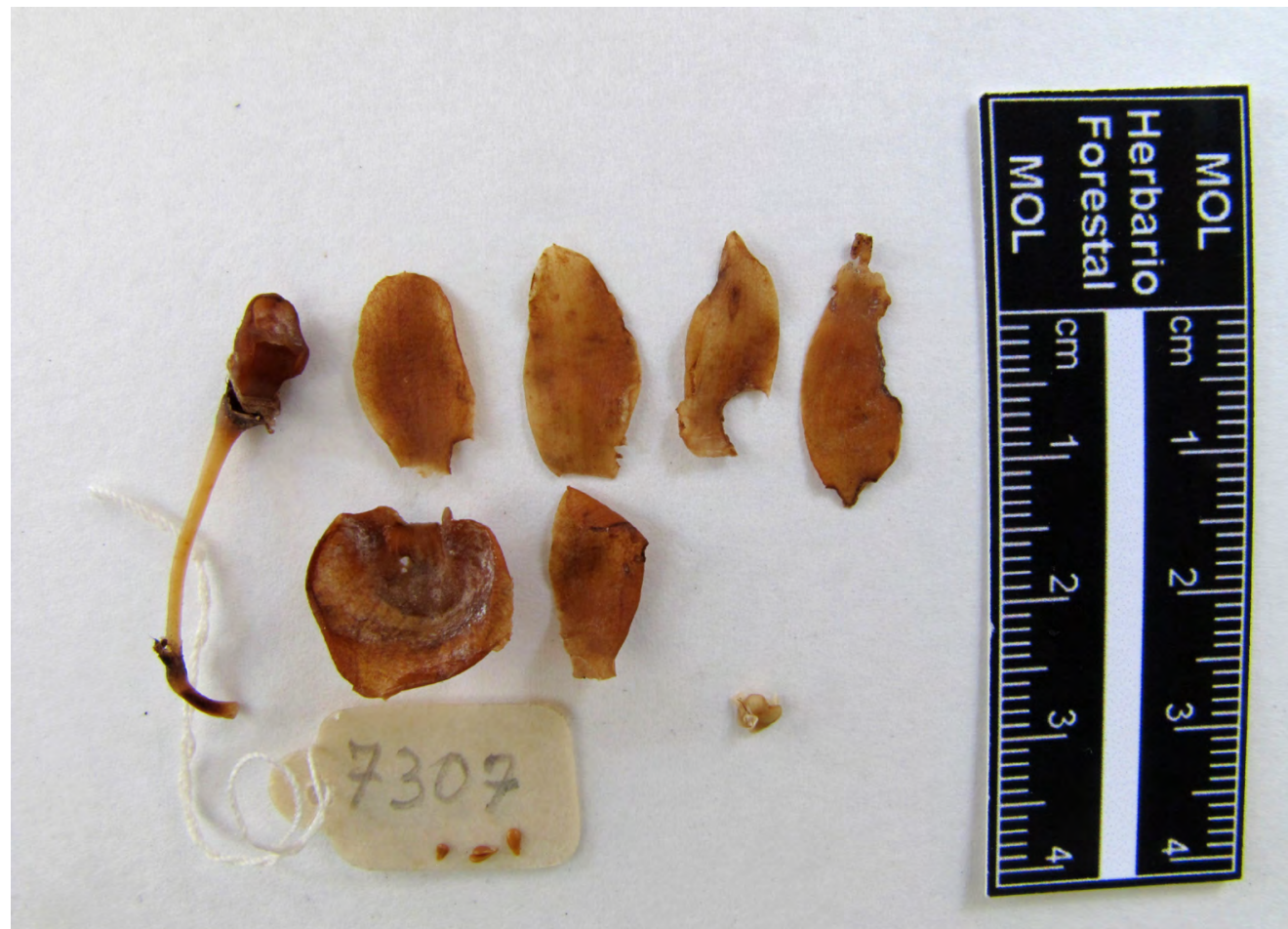

FiguRE 6. Chaubardiella serrulata D.E.Benn. \& Christenson. Holotype at MOL (Bennett 7307 in spirit). Photo: D. Trujillo. 


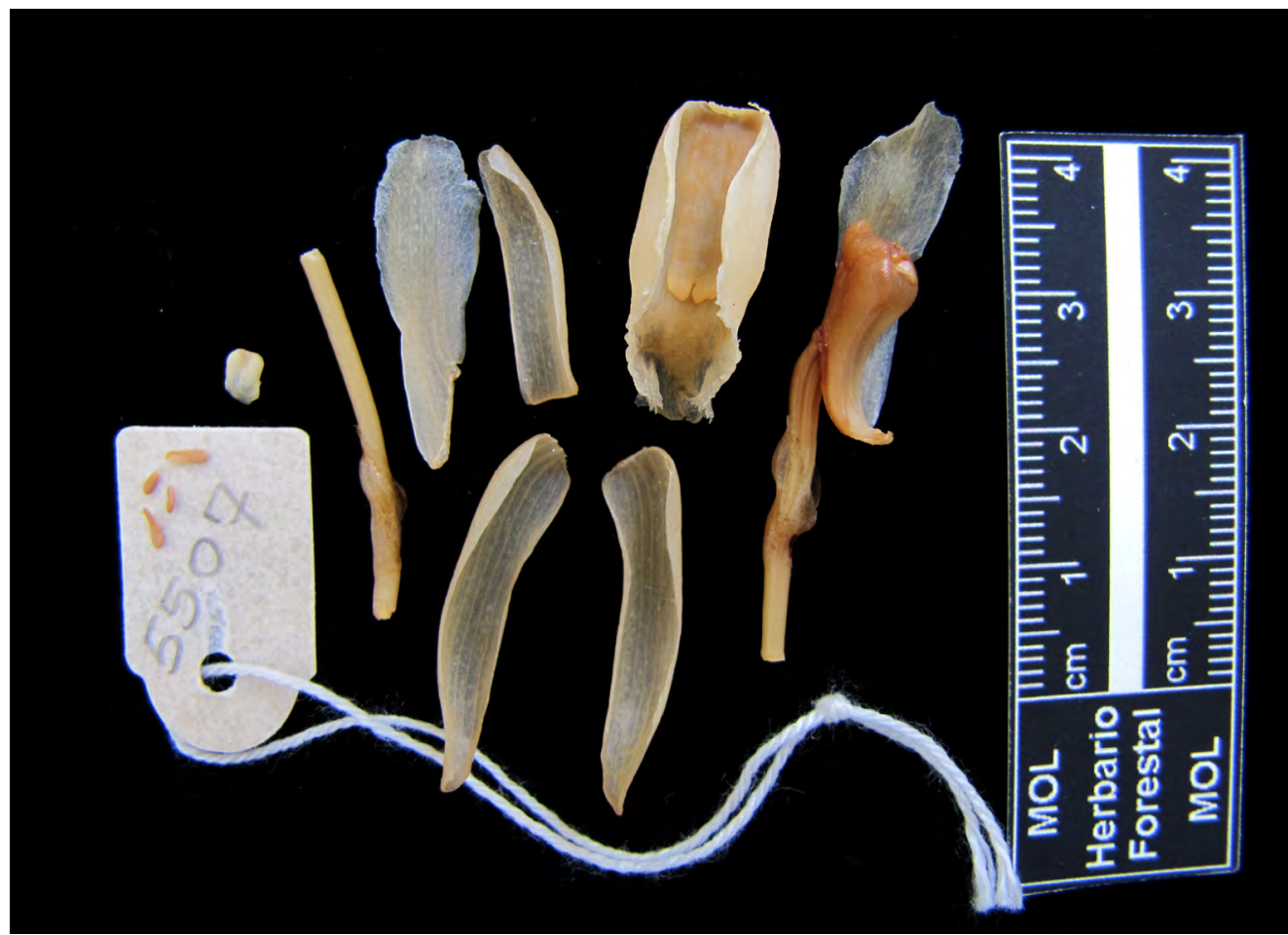

FiguRE 7. Chondrorhyncha plicata D.E.Benn. \& Christenson. Holotype at MOL (D. Bennett 5507 in spirit). Photo: D. Trujillo.
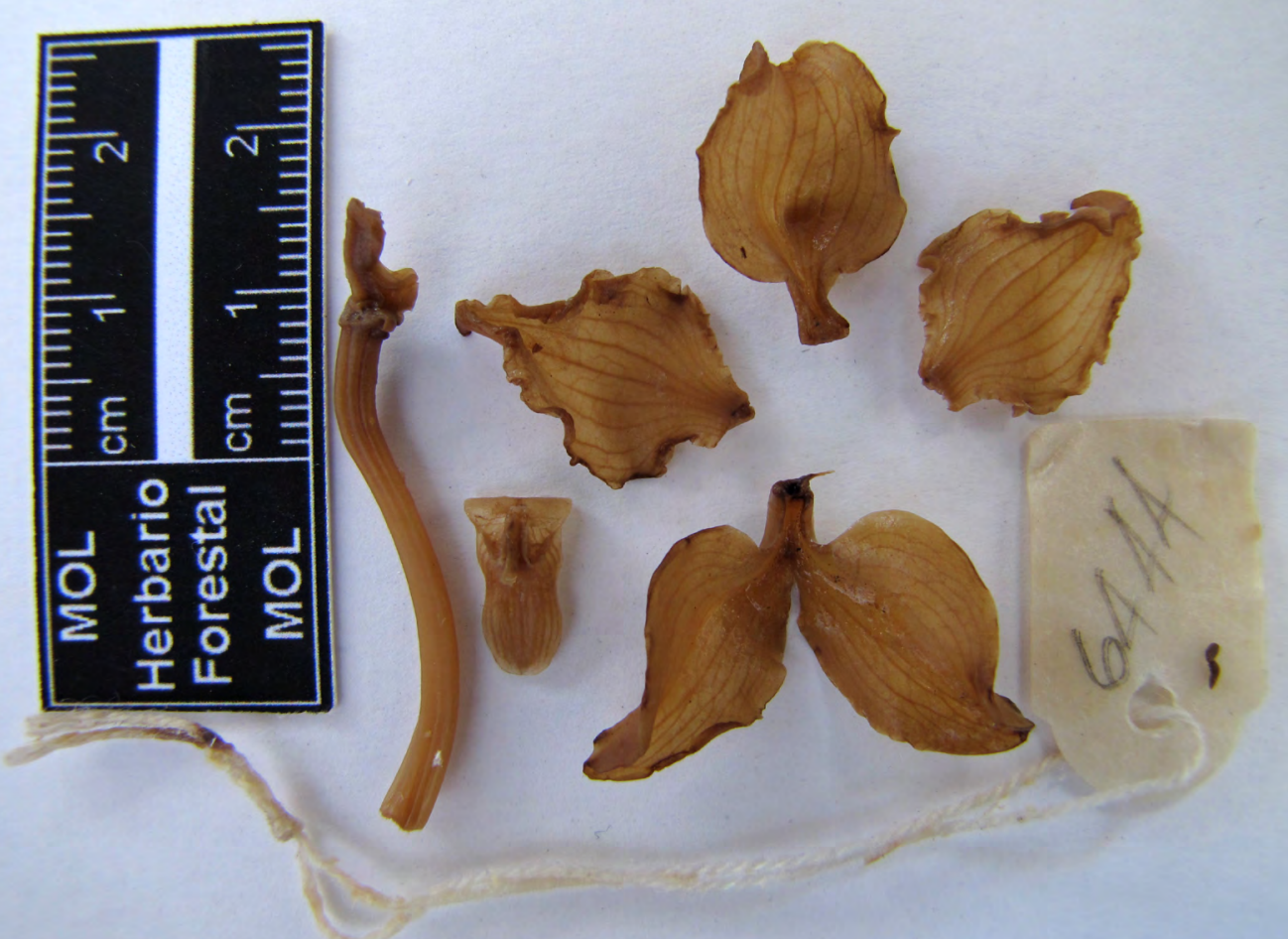

Figure 8. Cyrtochilum stegasaurum D.E.Benn. \& Christenson. Lectotype at MOL (Bennett 6444 in spirit). Photo: D. Trujillo. 
at USM; they have the same locality and date of preparation that is given in the protologue; however with a different collection number: "Ricardo Fernandez 23, ex Bennett 4568" (instead of R. Fernandez 89369). The collection number cited in the protologue is not R. Fernandez's number (pers. comm); therefore the original type citation in the protologue is erroneous and here is corrected.

Both specimens at USM have a printed label of the FLAS Herbarium that indicates that the specimens flowered in cultivation at the University of Florida. One specimen (USM-167755) has an additional label of Bennett's personal herbarium. However, neither of them has an annotation that indicates that it is the holotype. As there is not a clear holotype, a lectotype is designated here (ICN. Art. 9.2, 9A.3). The specimen chosen is the herbarium specimen at USM that has the Bennett's label.

Cyrtochilum mezae D.E.Benn. \& Christenson, Icon. Orchid. Peruv.: t. 623. 2001.

TYPE: Peru, Amazonas, Chachapoyas, 1800 m, [8] May 1992, J. Meza T. ex Bennett 5565. Holotype: originally deposited at Herb. Bennettianum, now at MOL; Isotype: MOL- spirit.

David Bennett wrote on the label of the herbarium specimen: "sp. nov"; but did not indicate that the flower in spirit was part of the same specimen. Therefore the specimen in spirit is an isotype (ICN. Art 8.3).

\section{Cyrtochilum plurituberculatum D.E.Benn. \&} Christenson, Icon. Orchid. Peruv.: t. 624. 2001.

TYPE: Peru, Amazonas, Chachapoyas, exact locality uncertain, J. Meza T. ex Bennett 5090. Holotype: originally deposited at Herb. Bennettianum, now at MOL, part in spirit.

Cyrtochilum stegasaurum D.E.Benn. \& Christenson, Icon. Orchid. Peruv.: t. 625. 2001.

TYPE: Peru, Huanuco, Leoncio Prado, $6 \mathrm{~km}$ SE Tingo Maria, 1000-1150 m, 28 Aug 1993, E. Jara P. ex Bennett 6441. Holotype: originally deposited at Herb. Bennettianum, [now at MOL], lost [see below]. Lестотуре here designated: Peru, [Piura, Huancabamba, 15-20 km NE from Huancabamba city,
3000 m, 22 Sept 1993, J. Campoverde s.n.,] ex Bennett 6444 (MOL-spirit; Fig. 8).

In the protologue Bennett 6441 was cited as holotype of Cyrtochilum stegasaurum. However, the specimen labeled Bennett 6441 found in the Bennett collection at MOL is an Oncidium species. This specimen has not locality data on the label, only the date of preparation: September 23, 1993. The Table Records of the illustrated Bennett's specimens indicates that Bennett 6441 is Oncidium retusum Lindl. Two specimens of Cyrtochilum collected from Huancabamba (Deptartment of Piura) by Jose Campoverde and labeled as Bennett 6444 are at MOL: one pressed and the other in spirit. The herbarium specimen consists of part of an inflorescence with just one flower and was prepared on September 22, 1993. The specimen in spirit is a dissected flower (without date of preparation) that agrees with the illustration of Cyrtochilum stegasaurum of the original publication. Although, Bennett 6444 was not found on the Table of Records of the illustrated Bennett's specimens; it seems that Bennett 6444 is the type of Cyrtochilum stegasaurum and the type designation in the protologue is erroneous.

The two specimens of Bennett 6444 (found at MOL) and the original illustration represent the original material of Cyrtochilum stegasaurum (ICN. Art. 9.3). In absence of the holotype, the specimen chosen here as lectotype is the dissected flower in spirit (ICN. Art. 9.12, 9A.3).

Cyrtochilum tricornis Dalström \& Ruíz-Pérez, Lankesteriana 12: 151. 2012.

TYPE: Peru, Cusco, Quillabamba, Rio Chullapi Reserva, 2000-2200 m, field collected by Luis Valenzuela and his team from the Cusco University, with J. Sönnemark and S. Dalström, 9 Dec. 2002, S. Dalström et al. 2699. Holotype: CUZ.

Bennett \& Christenson (1998) recognized Bennett 7672 as Oncidum saltabundum Rchb.f. in Icon. Orchid. Peruv.: t. 533 (1998). Dalström and Ruíz-Pérez (2012) during their research at herbaria collections did not find any preserved specimen of Bennett 7672 . Therefore, in the protologue of Cyrtochilum tricornis, they designated the published illustration (prepared on December 21, 1996) based on Bennett 7672 as 
paratype. However; during the present study, two specimens of Bennett 7672 were found in the Bennett Collection at MOL: one pressed and one in spirit. These specimens at MOL are not paratypes, because Dalström and Ruíz-Pérez (2012) did not definitely designate as types (ICN. Art 7 Ex.9).

Dichaea alcantarae D.E.Benn. \& Christenson, Lindleyana 13: 31. 1998.

TYPE: Peru, Pasco, Oxapampa, Villarica, $10 \mathrm{~km} \mathrm{SE} \mathrm{of}$ Canal de Piedra, 2000 m, Jan 1993, leg. O. del Castillo, Bennett 6060. Holotype: according to the protologue at USM, now deposited at MOL[-spirit] (Fig. 9).

Bennett 6060 in spirit was found in the Bennett Collection at MOL; however, a pressed preparation was not located in any Peruvian herbarium. The specimen consists of flowers that agree with the illustration of the original publication. Therefore the specimen in spirit is the holotype.

Dichaea caveroi D.E.Benn. \& Christenson, Icon. Orchid. Peruv.: t. 629. 2001.

TYPE: Peru, Amazonas, Condorcanqui, from area closely surrounding the Border Guard Post "Alfonso Ugarte" PV-3, 1300 m, Aug 1994, M. Cavero B. 1660 ex Bennett 6725. Holotype: Herb. Bennettianum [now at MOL], lost [see below]. Lectotype here designated: Peru, Amazonas, Condorcanqui, Puesto de Vigilancia PV-3, 1200 m, 30 Aug 1994, M. Cavero B. sn ex Bennett 6725 (MOL).

Two specimens of Bennett 6725 are in the Bennett Collection at MOL: one pressed and one in spirit. The herbarium specimen was prepared on August 30, 1994; the data on the label indicates that the specimen was collected at $1200 \mathrm{~m}$ and not at $1300 \mathrm{~m}$ as was cited in the protologue. The label also indicates the illustration number of the specimen (LAM-1059); but did not indicate that the specimen in spirit is part of the same specimen. The specimen in spirit consists of a dissected flower that agrees with the illustration of the original publication. The illustration was prepared on August 26, 1994; probably on this date the specimen in spirit was prepared. Both specimens at MOL represent the original material of Dichaea caveroi; however neither of them has an annotation that indicates it is the holotype. Therefore, as there is not a clear holotype, a lectotype is designated here from among the specimens that comprise the original material (ICN. Art. 9.12); the specimen chosen is the most complete pressed specimen.

Dichaea delcastilloi D.E.Benn. \& Christenson, Lindleyana 13: 33. 1998.

TYPE: Peru, Junin, Chanchamayo, Santa Cruz, 15 km SE of San Ramon, 2200 m, leg. O. del Castillo, Jan 1993, flowered in cultivation 11 Sept 1993 [1997 in error], Bennett 6106. Holotype: NY, lost; [Isotype: MOL-spirit, here designated as LectotyPe] (Fig. 10).

The holotype was not found at NY (T. Zanoni, pers. comm.). The protologue cites that the date of preparation of the holotype was on September 11, 1997; however it is erroneous. The correct date is September 11, 1993; which is also the same date when the specimen was illustrated.

Two specimens of Bennett 6106 are in the Bennett Collection at MOL: one in spirit and one pressed. The specimen in spirit consists of two flowers (one dissected) that agree with the illustration of the original publication. The date of preparation is not indicated on the label of this specimen; however, this was probably prepared on same date of the illustration (and the holotype). Therefore, the specimen in spirit represents the isotype. The herbarium specimen was prepared on September 12, 1993; which disagrees with the date given in the protologue.

In absence of the holotype, the extant isotype in spirit found in the Bennett Collection at MOL is here chosen as lectotype (ICN. Art. 9.12).

Dichaea longipedunculata D.E.Benn. \& Christenson, Icon. Orchid. Peruv.: t. 435. 1998.

TYPE: Peru, Cusco, Quillabamba, District of Quirimbiri, sector Qirimbiri river, $842 \mathrm{~m}, 26$ Sept 1995, O. del Castillo ex Bennett 7254. Holotype: USM, lost. LeCtotyPE here designated: Peru, without locality data [probably same as in the protologue], 11 Oct 1995, O. del Castillo ex Bennett 7254 (MOL).

Three specimens of Bennett 7254 were found in the Bennett Collection at MOL: one specimen in spirit 
(a dissected flower) and two pressed specimens with different dates of preparation; October 11, 1995 (this specimen lacks locality data) and November 27, 1995 (sterile), respectively. However, neither of the dates agree with that given in the protologue nor is there an annotation on the labels that indicates which one is the holotype. Therefore, as there is no holotype, a lectotype is designated here from among the specimens that comprise the original material (ICN. Art. 9.12); the specimen chosen is the most complete herbarium specimen.

Dichaea peruviensis D.E.Benn. \& Christenson, Icon. Orchid. Peruv.: t. 631. 2001.

TYPE: Peru, [Junin, Chanchamayo], without exact locality [prepared on 25 June 1994], Hort. E. Edwards ex Bennett 6605. Holotype: originally deposited at Herb. Bennettianum, now at MOL.

The label of the specimen indicates that even though the exact locality is unknown, the plant comes from Chanchamayo, Dpto. Junin; and the specimen was prepared on June 25, 1994.

\section{Dressleria bennettii H.G.Hills \& Christenson,} Brittonia 47: 184. 1995.

TYPE: Peru, Junin, Chanchamayo, $\mathrm{N}$ side of Rio Perené up the Ubiriki Valley, 3 hour walk by natives, 950 m, O.del Castillo ex D. Bennett 5064. Holotype: NCU; Isotypes: FLAS-spirit, NY, SEL-spirit, USM [isotypes not found].

Harold G. Hills (2012) in his taxonomic revision of Dressleria provided the following information for the type material: "Peru, Depto. de Junin, Chanchamayo, Ubiriki Valley, north side of Rio Perene, Oliveros del Castillo [Oliveras, in error], 6 June 1991, ex hort 23 June 1991, D.E. Bennett Jr. 5064-2. Holotype: NCU; isotypes: NY, K spirit”. Until now, only the holotype was found.

A pressed specimen of Dressleria bennettii: Bennett 5064-2 is in the Bennett Collection at MOL. This specimen was prepared on July 8, 1991 and assigned as isotype by David Bennett. However; this is not a duplicate (isotype) of the holotype because they were not made as a single gathering (ICN. Art. $8.2)$.
Elleanthus caveroi D.E.Benn. \& Christenson, Lindleyana 13: 33. 1998.

TYPE: Peru, Amazonas, Condorcanqui, surrounding area near PV-3 (border guard post), Aug 1994, 1300 m, M. Cavero B. et al. 1614. Holotype: MOL; Isotype: USM, [not there] [Syntypes, see below]. Lectotype here designated: Peru, without collection data [probably same as in the protologue], M. Cavero B. et al. 1614 (MOL; Isolectotype: MOL, MOL-spirit).

Type specimens were deposited at MOL by David Bennett seven years after their collection (in 2001) and never at USM. However, three specimens of $M$. Cavero 1614 were found in the Bennett collection at MOL: one in spirit and two pressed. The herbarium specimens were in separated sheets, un-mounted and lacking labels; only an annotation with the collection number. None of the specimens has an annotation that indicates which one is the holotype or that they constitute a single specimen. Therefore the three specimens found in the Bennett collection represent syntypes (ICN. Art. 40 Note 1). As there is not a clear holotype, a lectotype is designated here (ICN. Art. 9.2). The specimen chosen here as lectotype is the most complete pressed specimen.

Encyclia bennettii Christenson, Brittonia 46: 29. 1994.

TYPE: Peru, Dept. Huanuco, Prov. Huanuco, near Carpish Pass on Huanuco side, 2350 m, 31 Aug 1985, D. \& A. Bennett 3490. Holotype: according to the protologue at USM, now deposited at MOL[-spirit] (Fig. 11).

Basionym of: Prosthechea bennettii (Christenson) W.E.Higgins, Phytologia 82: 376 (1997 publ. 1998).

Bennett 3490 in spirit was found in the Bennett Collection at MOL; however, a pressed preparation was not located in any Peruvian herbarium. The specimen in spirit consists of three dissected flowers that agree with the illustration of the original publication. Therefore this specimen represents the holotype.

Epidendrum albifloroides D.E.Benn. \& Christenson, Icon. Orchid. Peruv.: t. 445. 1998.

TYPE: Peru, Huanuco, Leoncio Prado, Corazon de Jesus, $5 \mathrm{~km} \mathrm{~S}$ from Cueva de Las Pavas, $1500 \mathrm{~m}, E$. 
Jara P. ex Bennett 7322. Holotype: according to the protologue at USM, now deposited at MOL[-spirit] (Fig. 12).

Bennett 7322 in spirit was found in the Bennett collection at MOL; however, a pressed preparation was not located in any Peruvian herbarium. The specimen consists of three flowers (one dissected) that agree with the illustration of the original publication. Therefore the specimen in spirit is the holotype.

Epidendrum amplum D.E.Benn. \& Christenson, Lindleyana 13: 36. 1998.

TYPE: Peru, Pasco, Oxapampa, along road from Oxapampa to Pozuzo, 1400 m [1350 m, in error], [24] Aug 1988, D. Bennett \& A. Bennett 4362. Holotype: NY, lost; Isotype: according to the protologue at USM, now deposited at MOL, here designated as LECTOTYPE.

The holotype was not found at NY (T. Zanoni, pers. comm.). However, three specimens of Bennett 4362 are in the Bennett collection at MOL: one in spirit and two pressed. One of the herbarium specimens was prepared on August 24, 1988, which is the same date given in the protologue ("Aug 1988"). This is the isotype and it is here chosen as lectotype (ICN. Art. 9.12). The other pressed specimen found at MOL was prepared on August 29, 1989; this date of preparation disagrees with that given in the protologue.

The specimen in spirit consists of a part of an inflorescence (an incomplete branch) and a dissected flower which agrees with the illustration of the original publication. The illustration was prepared on September 25, 1995; probably this specimen was prepared on that date. Therefore, the specimen in spirit is not an isotype.

Epidendrum apaganoides D.E.Benn. \& Christenson, Icon. Orchid. Peruv.: t. 450. 1998.

TYPE: Peru, Pasco, Oxapampa, District of Villarica, lower elevations of Cerro Bocaz, 900-1000 m, Dec 1994, J. Campoverde ex Bennett 6820. Holotype: according to the protologue at USM, now deposited at MOL[-spirit] (Fig. 13); Isotype: NY? [see below].

Bennett 6820 (holotype) found in the Bennett Collection at MOL consist of a dissected flower in spirit that agrees with the illustration of the original publication. The illustration was prepared on December 7, 1994; probably on the date (day) that the specimen was prepared.

A herbarium specimen recently designated as isotype of Epidendrum apaganoides, was found at NY; however it is not an isotype because the collection number (that has the suffix " $A$ ") and elevation data of the specimen disagree with that given in the protologue: ex Bennett 6820-A and $2000 \mathrm{~m}$. Additionally, this specimen was prepared on December 12, 1994, five days later that the illustration (and the holotype).

Epidendrum azulense D.E.Benn. \& Christenson, Icon. Orchid. Peruv.: t. 452. 1998.

TYPE: Peru, Huanuco, Leoncio Prado, Cordillera Azul, 1450 m, 3 Nov 1986, [1480 m, 16 Nov 1986, in error], D. \& A. Bennett \& M. Arias 3726. Holotype: according to the protologue at USM, now deposited at MOL, part in spirit.

Bennett 3726 found in the Bennett collection at MOL consists of a pressed and a spirit preparations (a note on the label of the herbarium specimen indicates that the flower in spirit is part of the same specimen). The label also indicates that the specimen was collected (or prepared) on November 3, 1986 at 1450 $\mathrm{m}$ of elevation; which disagrees with the data given in the protologue. However, this specimen represents the holotype because both preparations agree with the illustration of the original publication; which was prepared nine years later (on October 26, 1995). Therefore the data cited in the protologue is erroneous and is here corrected.

Epidendrum bicirrhatum D.E.Benn. \& Christenson, Icon. Orchid. Peruv.: t. 453. 1998.

TYPE: Peru, Huanuco, Leoncio Prado, San Juan de Supte near Tingo Maria, $800 \mathrm{~m}$. Nov 1991, E. Jara P. ex Bennett 5393. Holotype: USM, lost; Isotype: NY, lost. Lectotype here designated: Peru, Huanuco, Leoncio Prado, San Jorge de Supte, 800 m, 20 Mar 1993. E. Jara P. ex Bennett 5393 (MOL).

No type specimen was found at USM or at NY (T. Zanoni, pers. comm.). However, five specimens of Bennett 5393 are in the Bennett collection at MOL: two in spirit and three pressed. The herbarium specimens 
have different dates of preparation: February 2, 1992, March 20, 1993 and August 14, 1993. None of these dates agrees with that given in the protologue. In absence of the holotype, a lectotype is designated here (ICN. Art. 9.2). The specimen chosen here as lectotype is the one that appears to be one of the branches illustrated in the original publication.

Epidendrum bidens D.E.Benn. \& Christenson, Icon. Orchid. Peruv.: t. 634. 2001.

TYPE: Peru, Huanuco, Leoncio Prado, Cueva de Las Pavas, ca 1000 m, 1992 [prepared on 16 Feb 2001], E. Jara P. ex Bennett 5706. Holotype: originally deposited at Herb. Bennettianum, now at MOL.

Four specimens of Bennett 5706 are in the Bennett collection at MOL: two in spirit and two pressed prepared on different dates: July 15, 1999 and February 16,2001 . The last was designated as holotype by David Bennett (handwriting on the label).

Epidendrum burtonii D.E.Benn. \& Christenson, Icon. Orchid. Peruv.: t. 635. 2001.

TYPE: Peru, Junin, Satipo, Calabazas, along road to Huancayo, 1700 m, 3 Mar 1990 [31 July 1987, in error], Bennett et al. 3987-1 [3987, in error]. Holotype: originally deposited at Herb. Bennettianum, now at MOL.

Five specimens of Bennett 3987 with and without suffix numbers that represent two different species are in the Bennett collection at MOL. The herbarium specimen labeled as Bennett 3997-1 and prepared on March 3, 1990 agrees with the illustration of Epidendrum burtonii in the original publication; therefore it is the holotype. The original type citation in the protologue is erroneous and is here corrected.

The other specimens found in the Bennett collection are: Bennett 3987 (two in spirit and one pressed) and Bennett 3987-2 (a pressed specimen); both correspond to Epidendrum goodspeedianum A.D.Hawkes (Icon. Orchid. Peruv.: t. 047 (1993).

Epidendrum caveroi D.E.Benn. \& Christenson, Lindleyana 13: 36. 1998.

TYPE: Peru, Amazonas, Condorcanqui, Meseta de Cerro Machinaza, 2100 m, Aug 1994, M. Cavero B. et al. 1625. Holotype: according to the protologue at USM, now deposited at MOL, part in spirit; Isotype: MOL [there is not isotype; see below].

Type specimens were deposited at MOL by David Bennett seven years later (in 2001) and never at USM. Two preparations of M. Cavero 1625 are in the Bennett collection at MOL: a pressed plant and flowers in spirit. The herbarium specimen was un-mounted and lacked a label; but with the collection number and an annotation that indicate: "unicato" [i.e. unicate]; which means that only one specimen was prepared. A careful examination of original illustration and both preparations of M. Cavero 1625 indicate that the flowers in spirit are part of the pressed preparation. As both preparations are now deposited in the same herbarium, they represent a single specimen; i.e. the holotype (ICN. Art. 8.2, Art. 8.3-Ex.5).

Epidendrum compressibulbum D.E. Benn. \& Christenson, Lindleyana 13: 36. 1998.

TYPE: Peru, Huanuco, Leoncio Prado, near Cueva de las Pavas, 1000 m, leg. E. Jara P. Sept 1991, flowered in cultivation Sept 1992, Bennett 5332. Holotype: NY, lost; Isotype: USM, lost. LeCTOTYPE here designated: Peru, without exact locality [probably same as in the protologue], 02 Feb 1992, Bennett 5332 (MOL, part in spirit).

The type specimens were not found at NY ( $\mathrm{T}$. Zanoni, pers. comm.) nor at USM. The extant original material found in the Bennett Collection at MOL is designated here as lectotype (ICN. Art. 9.12). This specimen lacks locality data on the label.

Epidendrum cryptotropis Hágsater, Collantes \& E.Santiago, Icon. Orchid. 14: t. 1420. 2013.

TYPE: Peru, Huancavelica, Bosque Amaru, 3200 m [2500-2700 m in error], September 1999, Reden Suárez \& Gissela Alegría ex Bennett 7945. Holotype: MOL.

The holotype, located at MOL, consists of two plants; that were originally unmounted, but placed inside a folder with collection data written on it. During the curation work at MOL the specimen was mounted on two sheets. The protologue indicates an erroneous elevation data (the right elevation is 3200 m) that is corrected here. 
Epidendrum delcastilloi D.E.Benn. \& Christenson, Lindleyana 13: 39. 1998.

TYPE: Peru, Pasco, Oxapampa, Puerto Bermudez, 250 m, 21 Aug 1991. Leg. O. del Castillo, flowered in cultivation Sept 1992, Bennett 5247. Holotype: USM, lost. Leстотуре here designated: Peru, Pasco, Oxapampa, Puerto Bermudez, 250 m, 14 Oct 1992, O. del Castillo ex D. E. Bennett 5247. Lectotype: NY!.

The holotype was not located in any Peruvian herbarium. Two specimens in spirit of Bennett 5247 were found in the Bennett collection at MOL: one is an intact flower and the other just an anther with two pollinia. Additionally, a herbarium specimen of Bennett 5247 at NY was annotated as isotype (by David Bennett?); however its date of preparation disagrees with that given in the protologue.

The specimens in spirit at MOL and the herbarium specimen at NY represent the original material of Epidendrum delcastilloi. In absence of the holotype, a lectotype is designated here from among the specimens that comprise the original material (ICN. Art. 9.2, 9.12). The specimen chosen as lectotype is the most complete specimen kept at NY.

\section{Epidendrum dialychilum subsp. peruvianum} D.E.Benn. \& Christenson, Lindleyana 13: 42.1998.

TYPE: Peru, Amazonas, Condorcanqui, in the inmediate vicinity of the Peruvian border guard station "Alfonso Ugarte" PV-3, 1250, Aug 1994, leg. M. Cavero et al., Bennett 6702. Holotype: NY!; Isotype: according to the protologue at USM, now deposited at MOL[-spirit].

Basionym of: Epidendrum rhopalostele Hágsater \& Dodson, Icon. Orchid. 4: t. 481. 2001.

Epidendrum frechetteanum D.E.Benn. \& Christenson, Icon. Orchid. Peruv.: t. 637. 2001.

TYPE: Peru, Huancavelica, Tayacaja, Cedroyoc, 2400 m, 15 Feb 1999, M. León M. et al. 2990. Holotype: originally deposited at Herb. Bennettianum, now at MOL [Syntypes, see below]. Lectotype here designated: Peru, Huancavelica, Tayacaja, Cedroyoc, 2400 m, 15 Feb 1999, M. León et al. 2990. Lectotype: MOL-spirit (Fig. 14); Isolectotype: MOL-spirit. Neotype here superseded: Peru, Pasco: Prov. Oxapampa. Dist. Huancabamba. Parque Nacional
Yanachaga Chemillen. Abra Yanachaga, 3000 - 3100 m, 20 Feb 2005; Edwin Becerra et al. 862; Neotype (proposed by Collantes \& Hágsater in Icon. Orchid. 14: t.1429. 2013): HOXA; Neoisotypes: MO, USM.

The field work report of M. León et al. indicates that specimens of M. León et al. 2990 were collected on February 15, 1999. The collection consisted of living plants and pressed and in spirit preparations.

Three specimens of M. León et al. 2990 were found in the Bennett collection at MOL: one pressed and two in spirit. The herbarium specimen was prepared latter on June 5, 1999 by David Bennett (from the living specimen collected by M. León); this date of preparation disagrees with the date given in the protologue.

One specimen in spirit comprises of a whole plant with a dissected flower; the other specimen in spirit comprises a stem with two flowers. These two specimens in spirit were prepared by M. León et al. Therefore their dates of preparation agree with that given in the protologue. However, none of the specimens has an annotation that indicates which one is the holotype or that they constitute a single specimen. Therefore both specimens represent syntypes (ICN. Art. 40 Note 1). As there is not a clear holotype, a lectotype is designated here (ICN. Art. 9.2). The specimen here chosen as lectotype is the most complete specimen in spirit that seems was the one used for preparing the illustration. (The collection data cited above for the lectotype was taken from the field work report of M. León et al.).

The lectotypification of Epidendrum frechetteanum based on original material supersedes the neotype proposed by Collantes \& Hágsater (2013) (ICN. Art. 9.13, 9.19(a)).

Epidendrum fujimorianum D.E.Benn. \& Christenson, Icon. Orchid. Peruv.: t. 459.1998.

TYPE: Peru, Huanuco, Leoncio Prado, along old road from Carpish to Tingo Maria, 2400 m, 31 Oct 1986 [30 Oct 1986, in error], D. Bennett et al. 3665. Holotype: according to the protologue at USM, now deposited at MOL, part in spirit.

The data written on the label indicates that the specimen was collected on October 31, 1986 not; on October 30, 1986, as cited in the protologue. 

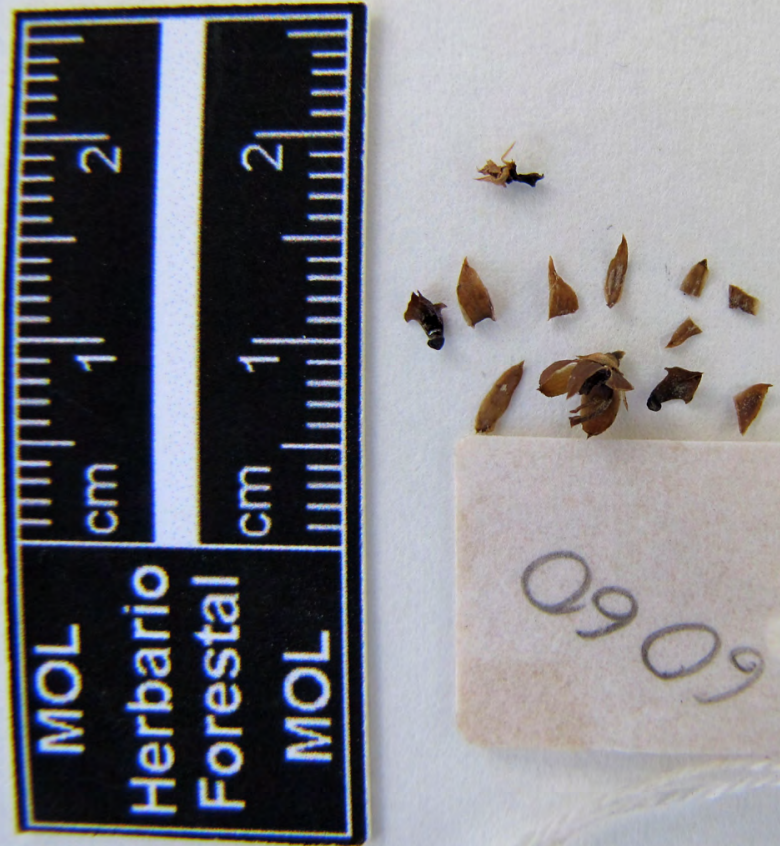

FIGURE 9. Dichaea alcantarae D.E.Benn. \& Christenson. Holotype at MOL (Bennett 6060 in spirit). Photo: D. Trujillo.

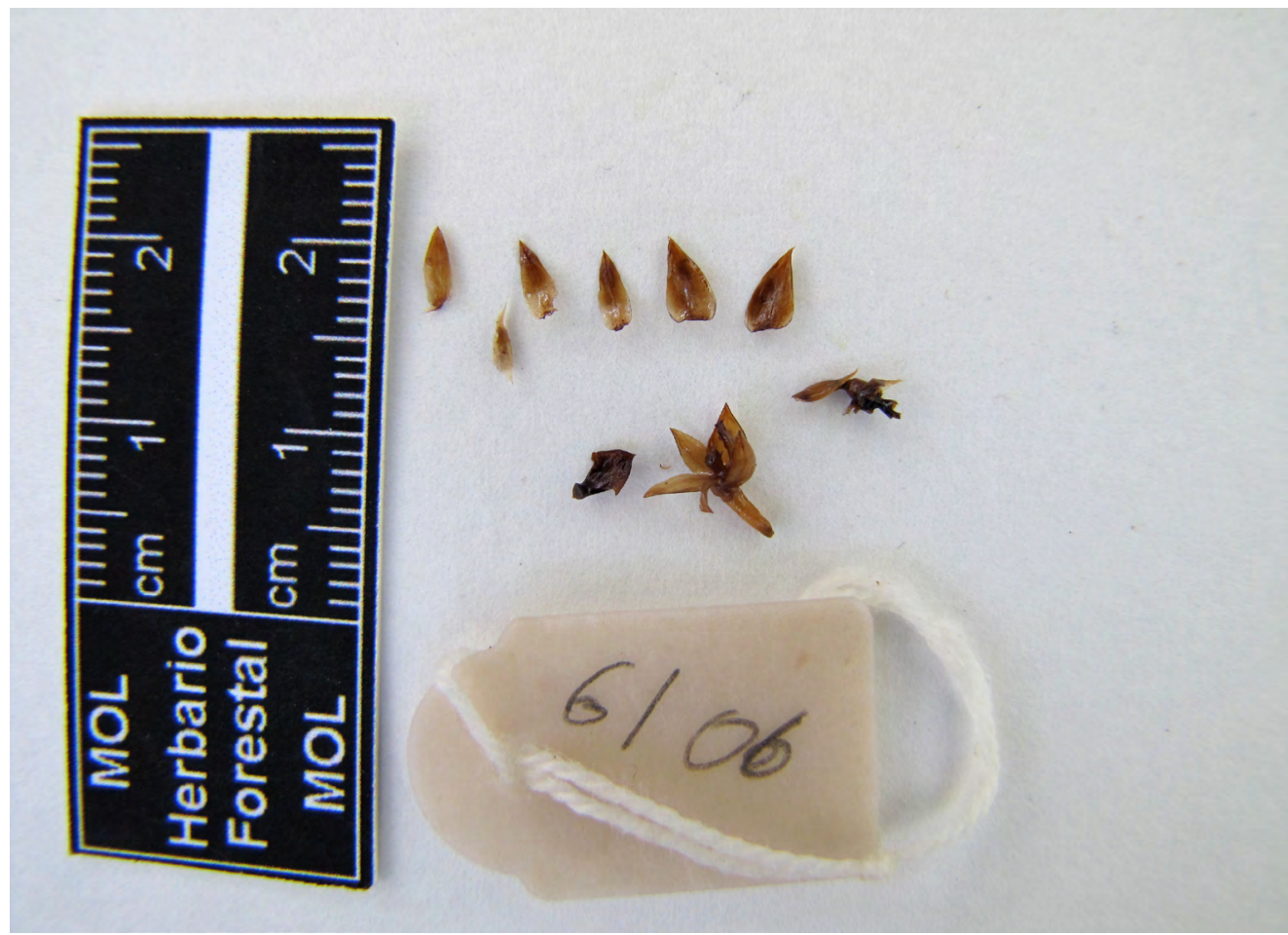

Figure 10. Dichaea delcastilloi D.E.Benn. \& Christenson. Lectotype at MOL (Bennett 6106 in spirit). Photo: D. Trujillo. LANKESTERIANA 14(1), April 2014. (C) Universidad de Costa Rica, 2014. 


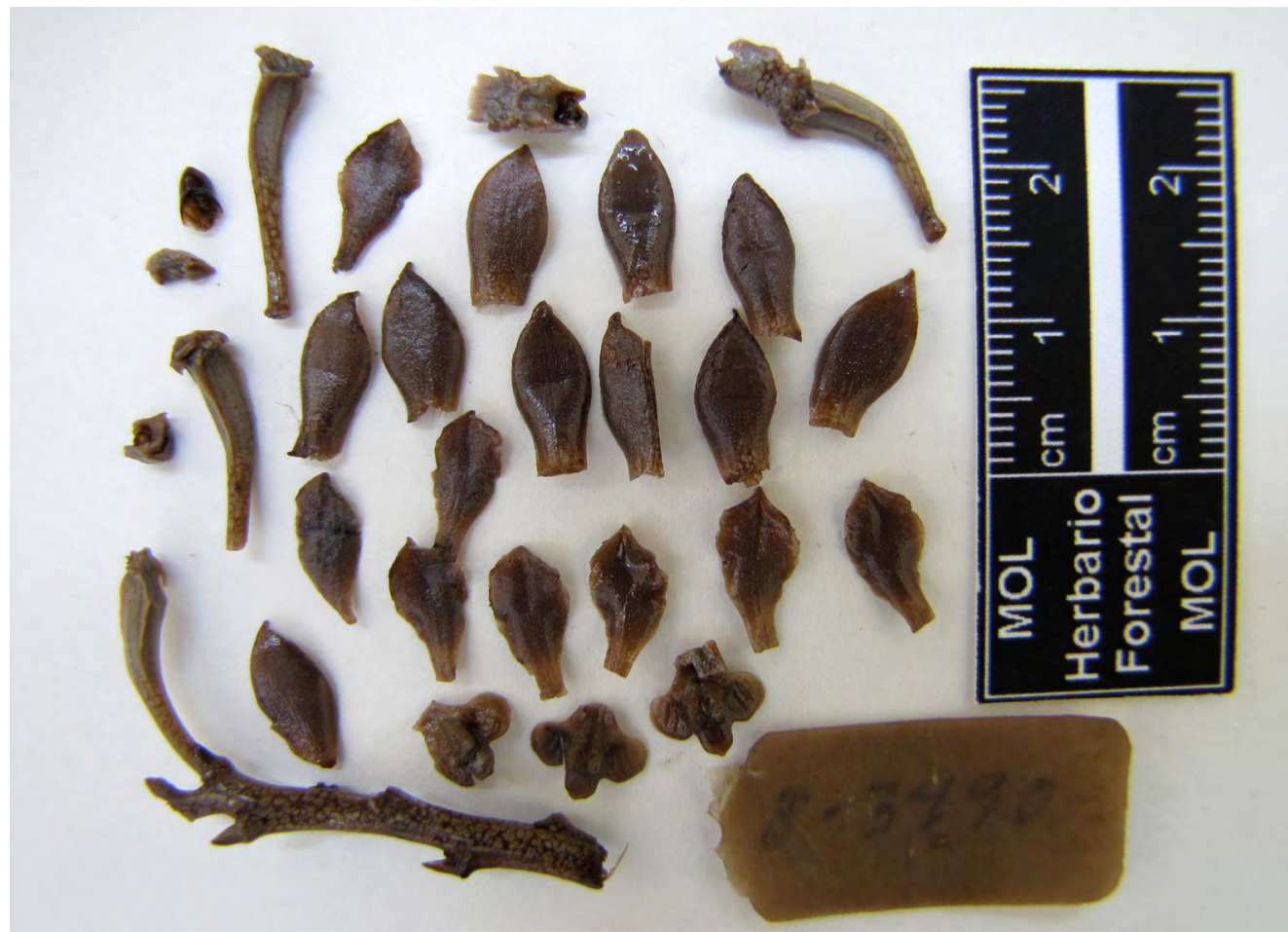

Figure 11. Encyclia bennettii Christenson. Holotype at MOL (Bennett 3490 in spirit). Photo: D. Trujillo.

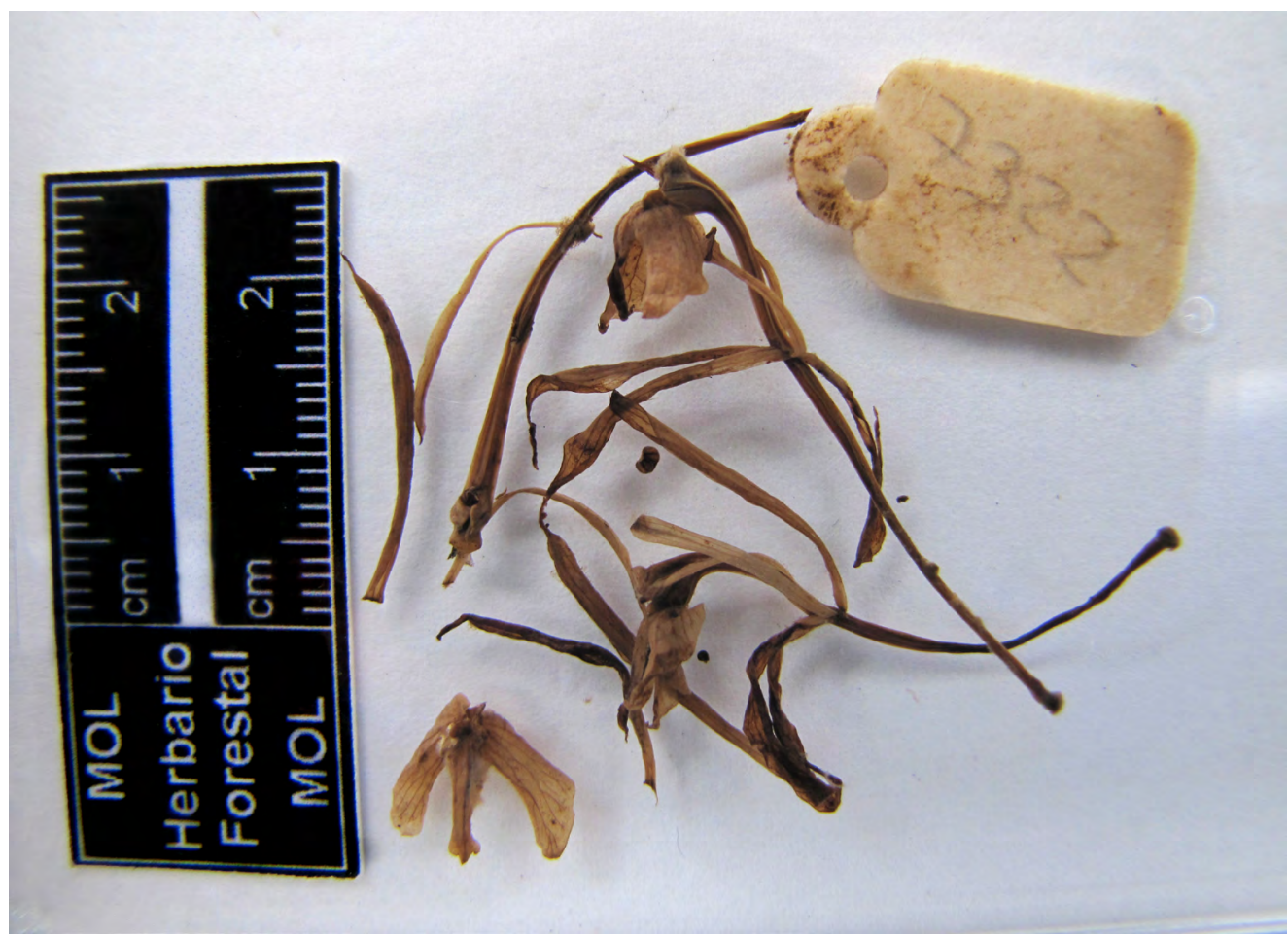

Figure 12. Epidendrum albifloroides D.E.Benn. \& Christenson. Holotype at MOL (Bennett 7322 in spirit). Photo: D. Trujillo. LANKESTERIANA 14(1), April 2014. (c) Universidad de Costa Rica, 2014. 


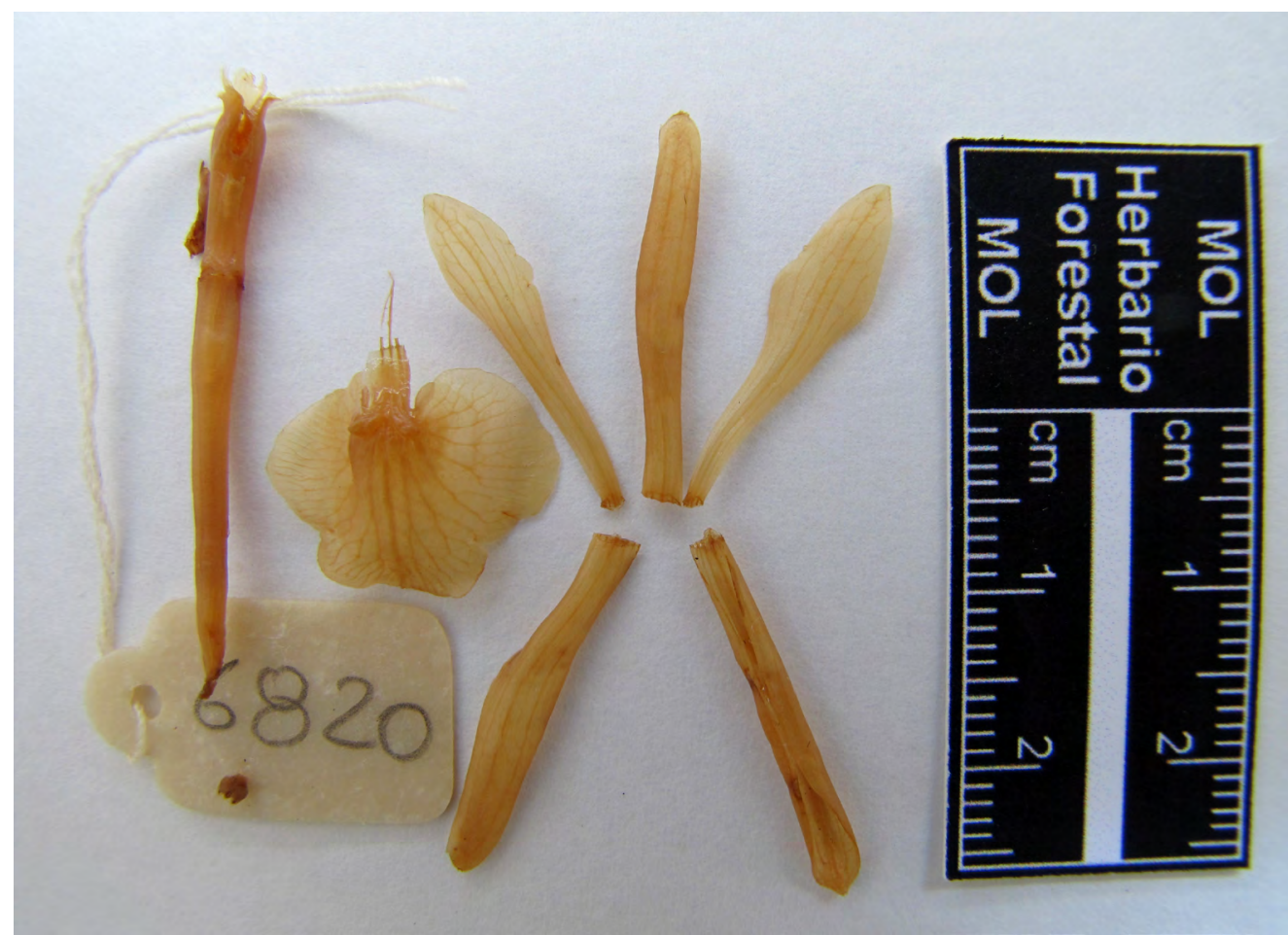

Figure 13. Epidendrum apaganoides D.E.Benn. \& Christenson. Holotype at MOL (Bennett 6820 in spirit). Photo: D. Trujillo.

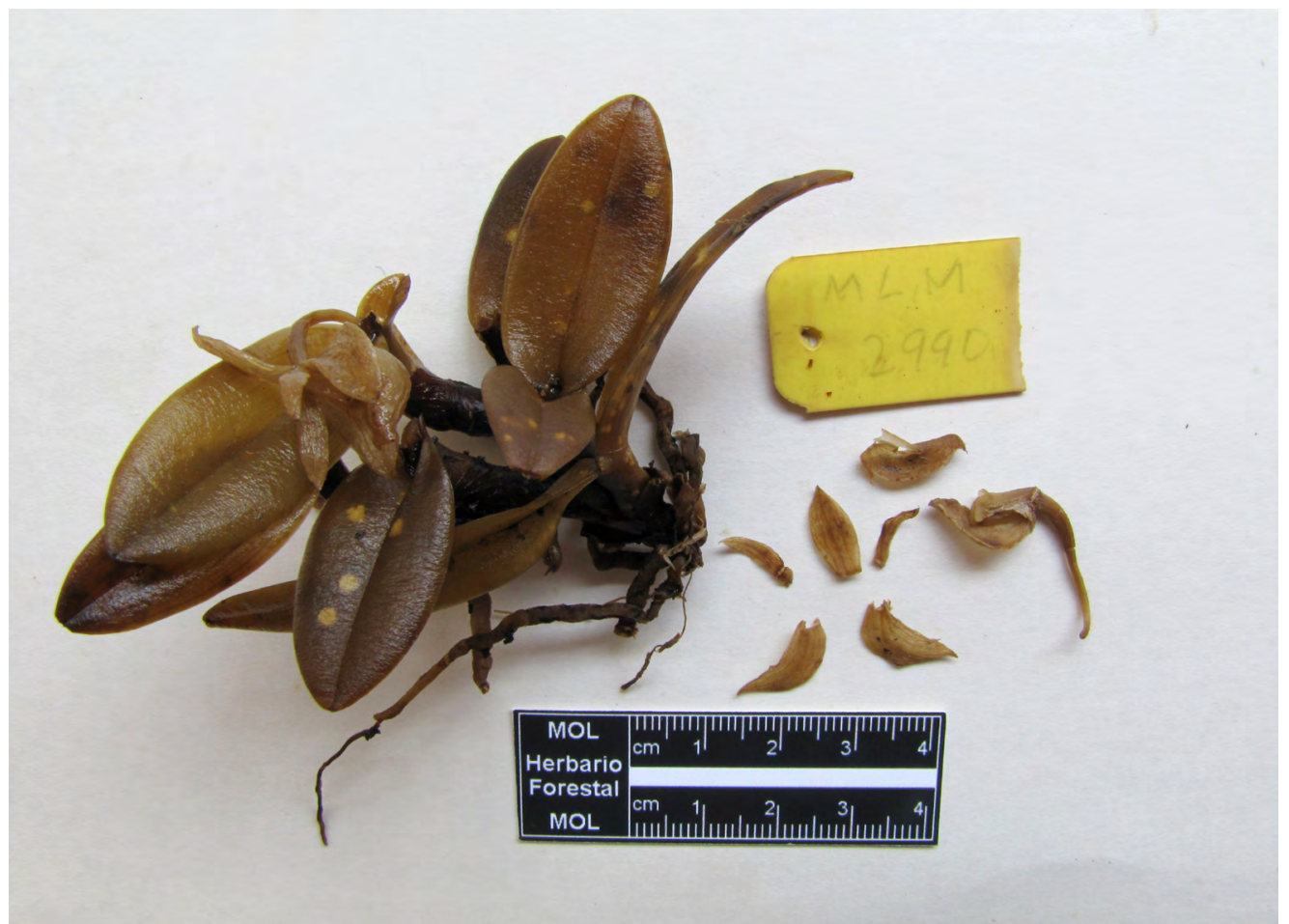

FiguRE 14. Epidendrum frechetteanum D.E.Benn. \& Christenson. Lectotype at MOL (M. León 2990 in spirit). Photo: D. Trujillo. 


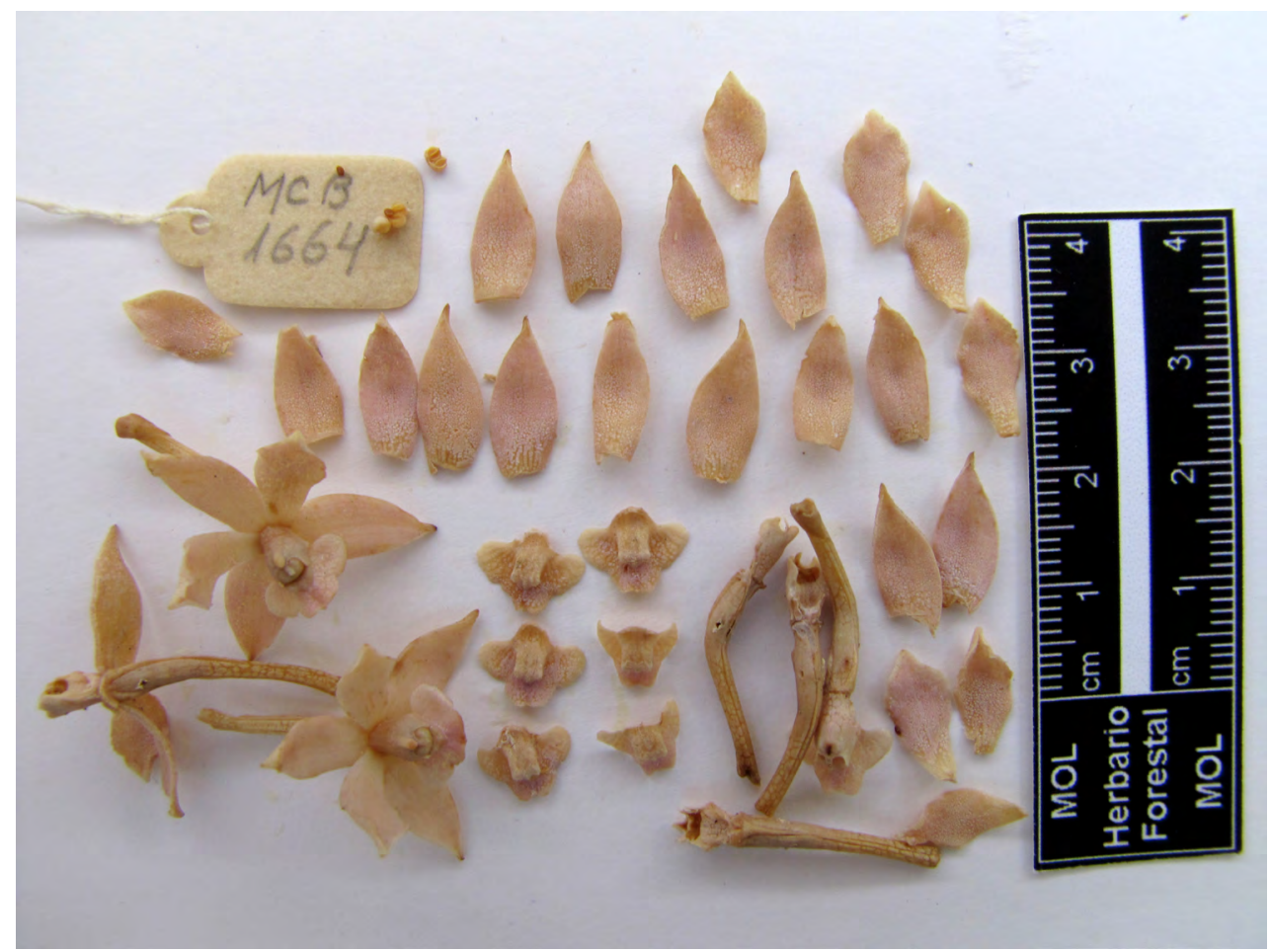

Figure 15. Epidendrum fuscum Schltr. Neotype at MOL (M. Cavero 1664 in spirit). Photo: D. Trujillo.

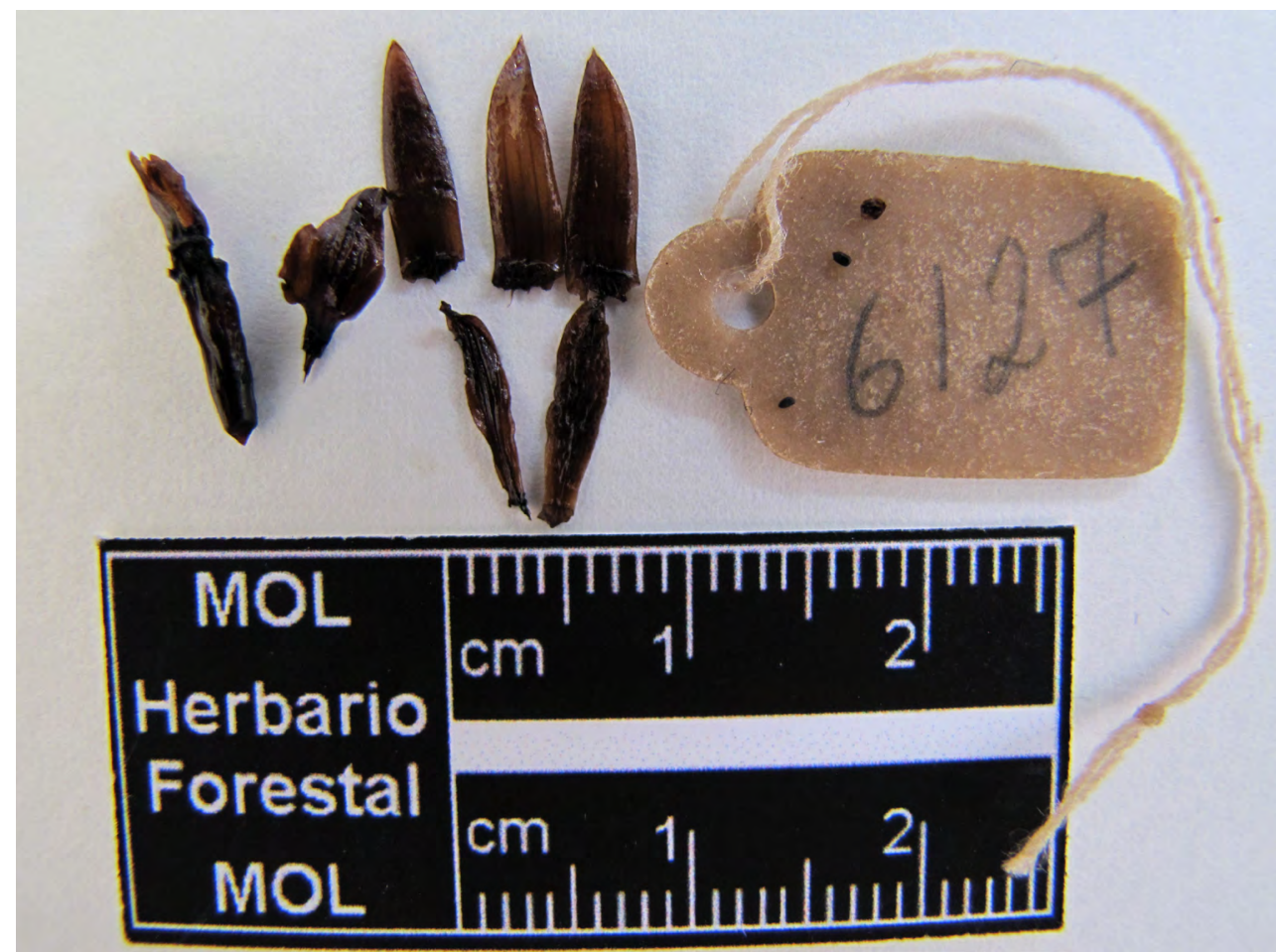

Figure 16. Epidendrum leonii D.E.Benn. \& Christenson. Lectotype at MOL (Bennett 6127 in spirit). Photo: D. Trujillo. LANKESTERIANA 14(1), April 2014. (C) Universidad de Costa Rica, 2014. 
The illustration published with the original publication of the species does not correspond to Epidendrum fujimorianum; as was already pointed out by Hágsater in Icon. Orchid. 8: t. 834 (2006).

Epidendrum fuscum Schltr., Repert. Spec. Nov. Regni Veg. Beih. 9: 84. 1921.

TYPE: Peru, Cajamarca, Easterns shelf of the Cordillera above Tabaconas, $2400 \mathrm{~m}$, May 1912, Weberbauer 6301. Holotype: B, destroyed. NEOTYPE (designated by Bennett \& Christenson in Icon. Orchid. Peruv.: t. 442. 1998): Peru, Cusco, Cusco, road to Quillabamba, ca. 2500 m, May 1995, M. Cavero \& J. León G. 1664 (according to the protologue at USM, now deposited at MOL[-spirit] (Fig. 15); Isoneotype: MOL, lost.

Basionym of: Prosthechea fusca (Schltr.) D.E.Benn. \& Christenson, Icon. Orchid. Peruv.: t. 750. 2001.

M. Cavero \& J. León G. 1664 in spirit was found in the Bennett collection at MOL; however, a pressed preparation was not located in any Peruvian herbarium. The specimen consists of flowers (some dissected) that agree with the illustration of the original publication.

The isoneotype was not found at MOL (not Bennett collection).

Epidendrum jarae D.E. Benn. \& Christenson, Icon. Orchid. Peruv.: t. 639. 2001.

TYPE: Peru, Huanuco, Leoncio Prado, San Jorge de Supte, about $3 \mathrm{kms}$ from Tingo Maria, ca $800 \mathrm{~m}$. Feb 1992, E. Jara P. ex Bennett 5396. Holotype: originally deposited at Herb. Bennettianum, now at MOL; [Isotypes: MOL-in spirit (x2)].

Two additional specimens of Bennett 5396 in spirit (isotypes) were found in the Bennett collection at MOL.

Epidendrum laxicaule D.E.Benn. \& Christenson, Lindleyana 13: 42.1998.

TYPE: Peru, Junin, Chanchamayo, Puerto Yurinaki, $1050 \mathrm{~m}, 200 \mathrm{~m}$ above the shoreline of Rio Perene, leg. O. del Castillo, 7 Jul 1991, flowered in cultivation Dec 1992, Bennett 5106. Holotype: according to the protologue at USM, now deposited at NY!; [Isotypes: MOL-spirit (x2)].

The holotype was found at NY. Two specimens of Bennett 5106 in spirit (isotypes) were found in the Bennett collection at MOL.

Epidendrum leonii D.E.Benn. \& Christenson, Lindleyana 13: 42. 1998.

TYPE: Peru, Pasco, Oxapampa, below Cacazu near Los Angeles bridge, $800 \mathrm{~m}$, leg. O. del Castillo, Feb 1993, flowered in cultivation Sept 1995, Bennett 6127. Holotype: NY, lost; Isotype: according to the protologue at USM, now deposited at MOL[-spirit], here designated as LeCTOTYPE (Fig. 16).

The holotype was not found at NY (T. Zanoni, pers. comm.). An extant isotype in spirit found in the Bennett collection at MOL is chosen here as lectotype (ICN. Art. 9.2, 9.12).

Epidendrum llactapataense D.E.Benn. \& Christenson, Icon. Orchid. Peruv.: t. 641. 2001.

TYPE: Peru, Huancavelica, Tayacaja: Llactapata, 2600 m, 14 Feb 1999 [prepared on 11 Mar 1999], M. León M. et al. 2967 [2966, in error] [ex Bennett 7891]. Holotype: originally deposited at Herb. Bennettianum, now at MOL.

The protologue cites M. León et al. 2966 as the type specimen of Epidendrum llactapataense. However, the field work report of M. León et al. indicates " $M L M$ 2966 " as Neodryas sp. (type of Neodryas acuminata D.E. Benn. \& Christenson (MOL!)) and the "MLM2967" as Epidendrum sp. Therefore the original type designation in the protologue is erroneous and is here corrected. The report of M. León et al. also indicates that they collected living plant(s) and prepared specimens in spirit and pressed of MLM-2967 on February 14, 1999.

Two specimens of Epidendrum llactapataense are in the Bennett Collection at MOL: one in spirit and one pressed. The specimen in spirit consists of an inflorescence with intact flowers. The herbarium specimen was prepared on March 11, 1999 by David Bennett (from the living specimen collected by $\mathrm{M}$. León et al.); it was incorrectly labeled as M. León 2966 (as it was cited in the protologue) and Bennett 
assigned his own collection number: Bennett 7891 . The herbarium specimen is the holotype.

An additional herbarium specimen of M. León 2967 was deposited by the collector to MOL; it was mounted specimen without a label. This specimen was not used by Bennett for the species description.

Epidendrum microcattleyioides D.E.Benn. \& Christenson, Icon. Orchid. Peruv.: t. 644. 2001.

TYPE: Peru, Huancavelica, Tayacaja, Huachocolpa, 3000 m, 28 Aug 1999, R. Suarez G. \& G. Alegria T. ex Bennett 7939. Holotype: originally deposited at Herb. Bennettianum, now at MOL[-spirit] (Fig. 17).

Bennett 7939 in spirit was found in the Bennett Collection at MOL; however, a pressed preparation was not located. The spirit specimen, consisting of a dissected flower that agrees with the illustration of the original publication is the holotype.

Epidendrum miradoranum Dodson \& D.E.Benn., Icon. Pl. Trop., II, 1: t. 66. 1989.

TYPE: Peru, Huanuco, Leoncio Prado, $10 \mathrm{~km}$ above Mirador, $20 \mathrm{~km}$ northeast of Carpish on road to Tingo Maria, 2400 to 2600 m, 8 Nov.1987. D. \& A. Bennett \& M. Arias 3679. Holotype: MO?.

Three specimens of Bennett 3679 were found in the Bennett collection at MOL: one in spirit and two pressed. The latter were prepared on: October 31, 1986 (two sheets) and November 3, 1986, respectively.

Epidendrum pseudapaganum D.E.Benn. \& Christenson, Icon. Orchid. Peruv.: t. 468. 1998.

TYPE: Peru, Cajamarca, San Ignacio District, San Ignacio sector, $2650 \mathrm{~m}, O$. del Castillo ex Bennett 6392. Holotype: USM, lost.

LeCTOTYPE here designated: Peru, without collection data, Bennett 6392-2 (MOL-spirit; Fig. 18).

The holotype was not located in any Peruvian herbarium. A specimen of Bennett 6392-2, in spirit in the Bennett collection at MOL, consists of four flowers that agree with the species description. In absence of the holotype, this specimen (original material) is here designated as lectotype (ICN. Art. 9.2, 9.12).
Epidendrum pseudoalbiflorum D.E.Benn. \& Christenson, Icon. Orchid. Peruv.: t. 467. 1998.

TYPE: Peru, Amazonas, Condorcanqui, Meseta de Cerro Machinaz, 2100, August 1994, M. Cavero B. et al.1628. Holotype: according to the protologue at USM, now deposited at MOL, part in spirit.

The holotype was deposited at MOL by Bennett in 2001 and never at USM. The pressed specimen was un-mounted and lacked a label; only an annotation with the collection number.

Epidendrum pseudoanceps D.E. Benn. \& Christenson, Lindleyana 13: 46. 1998.

TYPE: Peru, Huanuco, Leoncio Prado, below El Mirador, 1800 m, 10 Aug 1966, Bennett 2333. Holotype: AMES, lost. Paratype: Peru, Dept. Huanuco, Prov. Leoncio Prado, along road above Cueva de Pavas, 1400 m. 10 Nov 1991. D. Bennett \& A. Bennett 5354. Paratype: USM, lost. LectotyPe here designated: Peru, Huanuco, Leoncio Prado, Monzon, 850 m, 13 Dec 1991. Bennett 5354-3 (MOL).

Synonym of: Epidendrum forcipatum C. Schweinf. proposed by Hágsater \& Sanchez. Icon. Orchid. 12: t. 1243. 2009.

Bennett 2333; holotype of Epidendrum pseudoanceps, was not found at AMES (G. A. Romero, pers. comm.). Hágsater \& Sanchez (2009) indicate that there is a specimen in SEL with the same collection number of the holotype; however this specimen was collected in Tarma (Junin) on March 6, 1967. Therefore, it is not part of the original gathering.

The original material of Epidendrum pseudoanceps found in the Bennett collection at MOL consists of two specimens of Bennett 5354 with different suffixes; representing gatherings from cultivated plants and used for describing this species (ICN. Art. 9.3). They have different dates of preparation: Bennett 5354-3 prepared on December 13, 1991 and Bennett 5354-2 on April 1, 1992 (this specimen has no locality data on the label). As uncited specimens exist, the lectotype is chosen from among them (ICN. Art. 9.12). The specimen chosen here as lectotype is Bennett 5354-3; which was probably used for another illustration of the species prepared on December 5, 1991 and published by Bennett \& Christenson in the Icon. Orchid. Peruv.: t. 469 (1998). 
Epidendrum pseudogramineum D.E.Benn. \& Christenson, Icon. Orchid. Peruv.: t. 648. 2001.

TYPE: Peru, Cusco, Urubamba, Historic Santuary of Machu Picchu, 3200 m, 13 Sept 2000, M. León M. \& B. Collantes M. 4035. Holotype: CUZ?; Isotype: Herb. Bennettianum, lost [see below].

The date of preparation of M. León M. \& B. Collantes M. 4035 found in the Bennett collection at MOL disagrees with that given in the protologue: October 4, 2000 (on this date was also prepared the illustration). This specimen is not a duplicate (isotype) of the holotype because they were not made as a single gathering (ICN. Art. 8.2).

Epidendrum pseudopolystachyum D.E.Benn. \& Christenson, Icon. Orchid. Peruv.: t. 649. 2001.

TYPE: Peru, Junin, Chanchamayo, Chipes sector, near San Vicente mine, $1800 \mathrm{~m}, 10$ Sept 1992, $O$. del Castillo ex Bennett 5982. Holotype: originally deposited at Herb. Bennettianum, now at MOL[-spirit] (Fig. 19).

Bennett 5982 in spirit was found in the Bennett collection at MOL; however, a pressed preparation was not located. The spirit specimen, consisting of two flowers (one dissected) that agree with the illustration of the original publication is the holotype.

Epidendrum ruizlarreanum D.E.Benn. \& Christenson, Icon. Orchid. Peruv.: t. 651. 2001.

TYPE: Peru, Cusco, Convencion, Shell Corporation helipad \#29, $12^{\circ} 22^{\prime} 6.6$ "S, $73^{\circ} 12^{\circ} 42.97^{\prime \prime} \mathrm{W}$, mountain ridge, $1300 \mathrm{~m}$, Nov 1998, M. Cavero B. ex Bennett 7833. Holotype: originally deposited at Herb. Bennettianum, now at MOL[-spirit] (Fig. 20).

Bennett 7833 in spirit was found in the Bennett collection at MOL; however, a pressed preparation was not located. The spirit specimen, consisting of two flowers (one dissected) that agree with the illustration of the original publication is the holotype.

A herbarium specimen with the suffix "1"; i.e. Bennett 7833-1 was also found at MOL; this specimen was prepared on December 3, 1998. This specimen is part of the original material.
Epidendrum schizoclinandrium D.E.Benn. \& Christenson, Icon. Orchid. Peruv.: t. 653. 2001.

TYPE: Peru, Pasco, Oxapampa, along road to Pozuzo, 1840 m, 25 Aug 1978, D. \& A. Bennett \& A. Vargas $P$. 4473. Holotype: originally deposited at Herb. Bennettianum, now at MOL[-spirit] (Fig. 21).

Bennett 4473 in spirit was found in the Bennett collection at MOL; however, a pressed preparation was not located. The spirit specimen, consisting of six flowers (one dissected) that agree with the illustration of the original publication is the holotype.

Epidendrum schunkei D.E.Benn. \& Christenson, Lindleyana 13: 48. 1998.

TYPE: Peru, Tumbes, Zarumilla, El Caucho, leg. J. Schunke., 17 Sept 1966 [May 1977, flowered in cultivation Apr. 1970, in error], Bennett 3154. Holotype: AMES!; Isotype: UC?.

The dates of collection and preparation of the type specimen in the protologue are erroneous; because (according to the protologue) the plant flowered in cultivation (April 1970) before being collected (May 1977). The label on the holotype specimen at AMES (HUH-00287649) indicates that the specimen was collected on September 17, 1966.

Two specimens (clones) of Bennett 3154 with suffixes are in the Bennett Collection at MOL; a herbarium specimen of Bennett 3154-1 prepared on August 1985 and a specimen in spirit (an intact flower) with two labels: Bennett 3154-1 and Bennett 3154-2.

Epidendrum semiteretifolium D.E.Benn. \& Christenson, Brittonia 47: 187. 1995.

TYPE: Peru, Pasco, Oxapampa, near crossroad junction of Puerto Bermudez and Iscosan, 650 m, 16 Apr 1991, O. del Castillo ex Bennett 5033. Holotype: according to the protologue at NY, now deposited at MOL, [Isotype: MOL-spirit].

The holotype never was sent to NY. The herbarium specimen found in the Bennett collecition at MOL has an annotation that indicates that it is the holotype. Bennett 5033 in spirit (part of an inflorescence) was also found in the same collection (isotype). 
Epidendrum septumspinae D.E.Benn. \& Christenson, Icon. Orchid. Peruv.: t. 655. 2001.

TYPE: Peru, Huanuco, Leoncio Prado, Cueva de Las Lechuzas. $1000 \mathrm{~m}$ [Junin, Chanchamayo, SE of San Ramon near Rio Los Siete Espinas, 1200 m, in error], 26 Mar 1992, E. Jara sn [S. Castro, in error], ex Bennett 5485. Holotype: originally deposited at Herb. Bennettianum, now at MOL, part in spirit.

Bennett 5485 found in the Bennett collection at MOL agrees with the description of Epidendrum septumspinae. However, the data on the label of Bennett 5485 indicates that the specimen was collected by "E. Jara, in Cueva de las Lechuzas, Leoncio Prado, Dpto. Huanuco". Therefore the collection data cited in the protologue are erroneous and are corrected here.

Epidendrum avicula Lindl published in Icon. Orchid. Peruv.: t. 239 (1995); was based on S. Castro ex Bennett 5489; and this specimen has the locality data that erroneously was cited for the type of $E$. septumspinae.

Epidendrum uncinatum D.E.Benn. \& Christenson, Icon. Orchid. Peruv.: t. 473. 1998.

TYPE: Peru, Huanuco, Leoncio Prado, near Cueva de Las Pavas, 1000 m, 7 July 1992, E. Jara P. ex Bennett 5711. Holotype: according to the protologue at USM, now deposited at MOL[-spirit] (Fig. 22). Paratype: Peru, Oxapampa, District of Huancabamba, Caserio (villaje) Culebramarca, $2160 \mathrm{~m}$ [2610 m, in error], [28] Nov 1995, O. del Castillo ex Bennett 7381. Paratype: according to the protologue at USM, now deposited at MOL, part in spirit.

Bennett 5711 in spirit was found in the Bennett collection at MOL; however, a pressed preparation was not located in any Peruvian herbarium. The spirit specimen, consisting of two flowers (one dissected) that agree with the illustration of the original publication is the holotype.

Galeottia peruviana D.E.Benn. \& Christenson, Lindleyana 13: 48. 1998.

TYPE: Peru, Junin, Chanchamayo, 2 hour walk up the course of Rio Yurinaki, 1220 m, leg. O. del Castillo, Aug 1991, flowered in cultivation Jan 1992, Bennett
5179. Holotype: according to the protologue at USM, now deposited at MOL.

Gongora cruciformis Whitten \& D.E.Benn., Brittonia 46: 230. 1994.

TYPE: Peru, Pasco, Oxapampa, Puerto Bermudez near the Fundo of Jesus Saldaña, flowered in cultivation at FLAS 3 Mar 1993, Bennett 4696-5. Holotype: USM!; Isotypes: FLAS!, NY!, SEL, [AMES!, USM!]. Paratype: Peru, Huanuco, Leoncio Prado, 5-8 km along road to Carpish above Tingo Maria, E. Jara ex Bennett 4049. Paratypes: FLAS!, [USM(x2)!].

Two herbarium specimens of Bennett 4049 are in the Bennett collection at MOL; respectively prepared on October 18, 1987 and February 18, 1990. However these specimens at MOL are not paratypes because they have different dates of preparation than the type specimens (the paratypes were prepared on June 5, 1991).

Gongora erecta Whitten \& D.E.Benn., Brittonia 50: 186. 1998.

TYPE: Peru, Pasco, Oxapampa, $4 \mathrm{~km} \mathrm{~S}$ of Puerto Bermudez, on fundo of Celestino Ollero, $350 \mathrm{~m}$, leg. O. del Castillo, flowered in cultivation at FLAS, 14 Jul 1994, Bennett 4700-1. Holotype: USM!; Isotypes: FLAS!, NY!, [MOL].

In addition to the isotype; four specimens of Bennett 4700-1 are in the Bennett Collection at MOL: one specimen in spirit and three herbarium specimens prepared on different dates: July 15, 1991, August 13, 1991 and September 28, 1991; these specimens are part of the original material.

Ida hajekii D.E.Benn. \& Oakeley, Orchid Digest 67: 16. 2003.

TYPE: Peru, Pasco, Oxapampa, below Villarica 600$800 \mathrm{~m}$, towards Puerto Bermudez, 1998, cult. C. Hajek [prepared on 20 Mar 1999], R. Monterrey in Bennett 7895. Holotype: according to the protologue in K, now deposited at MOL; Isotypes: originally deposited at Herb. Bennettianum, now at MOL, [MOL-spirit].

Synonym of: Ida diastasia (D.E.Benn. \& Oakeley) A.Ryan \& Oakeley according to H. Oakeley 2008, 


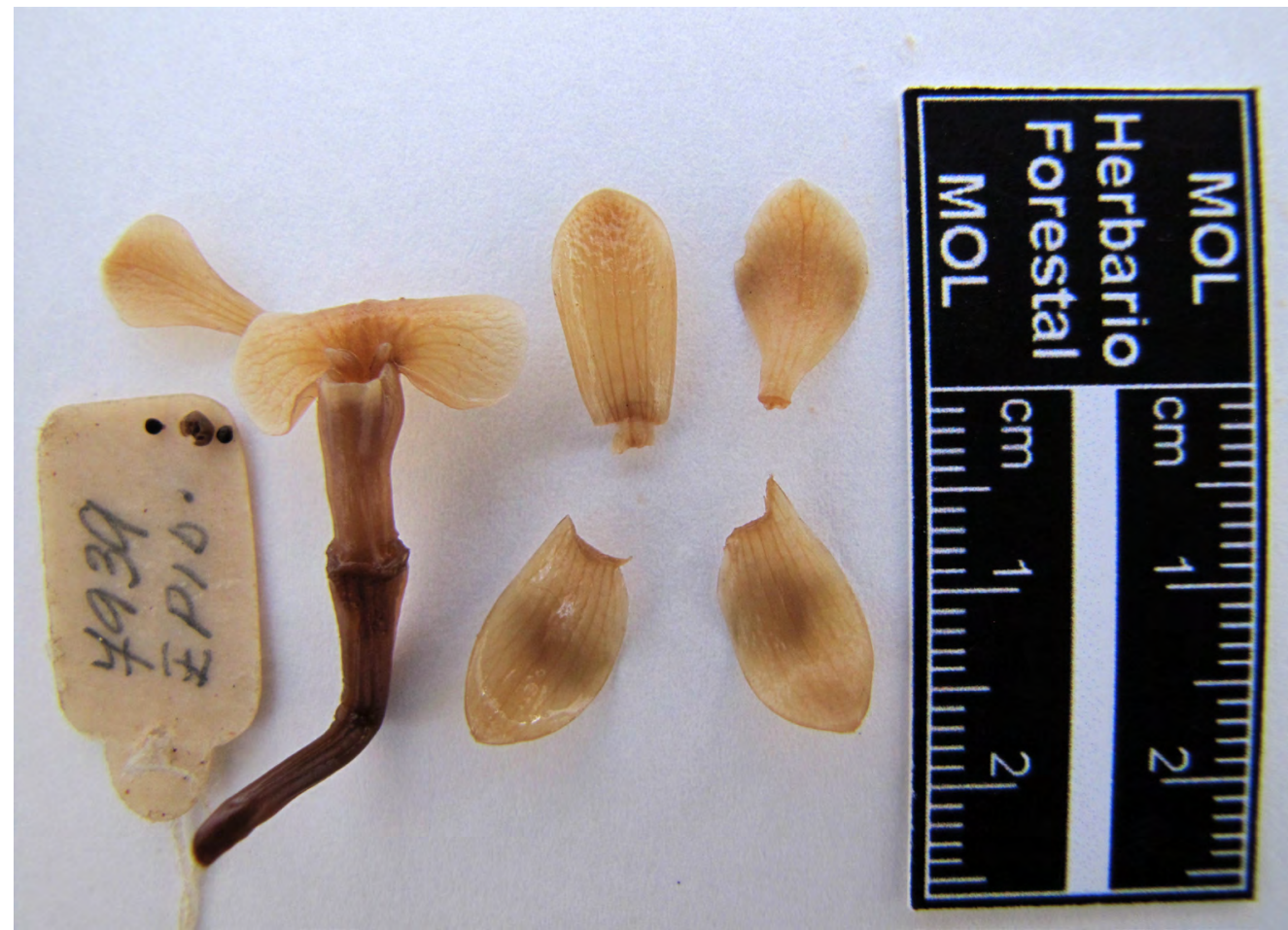

Figure 17. Epidendrum microcattleyioides D.E.Benn. \& Christenson. Holotype at MOL (Bennett 7939 in spirit). Photo: D. Trujillo.

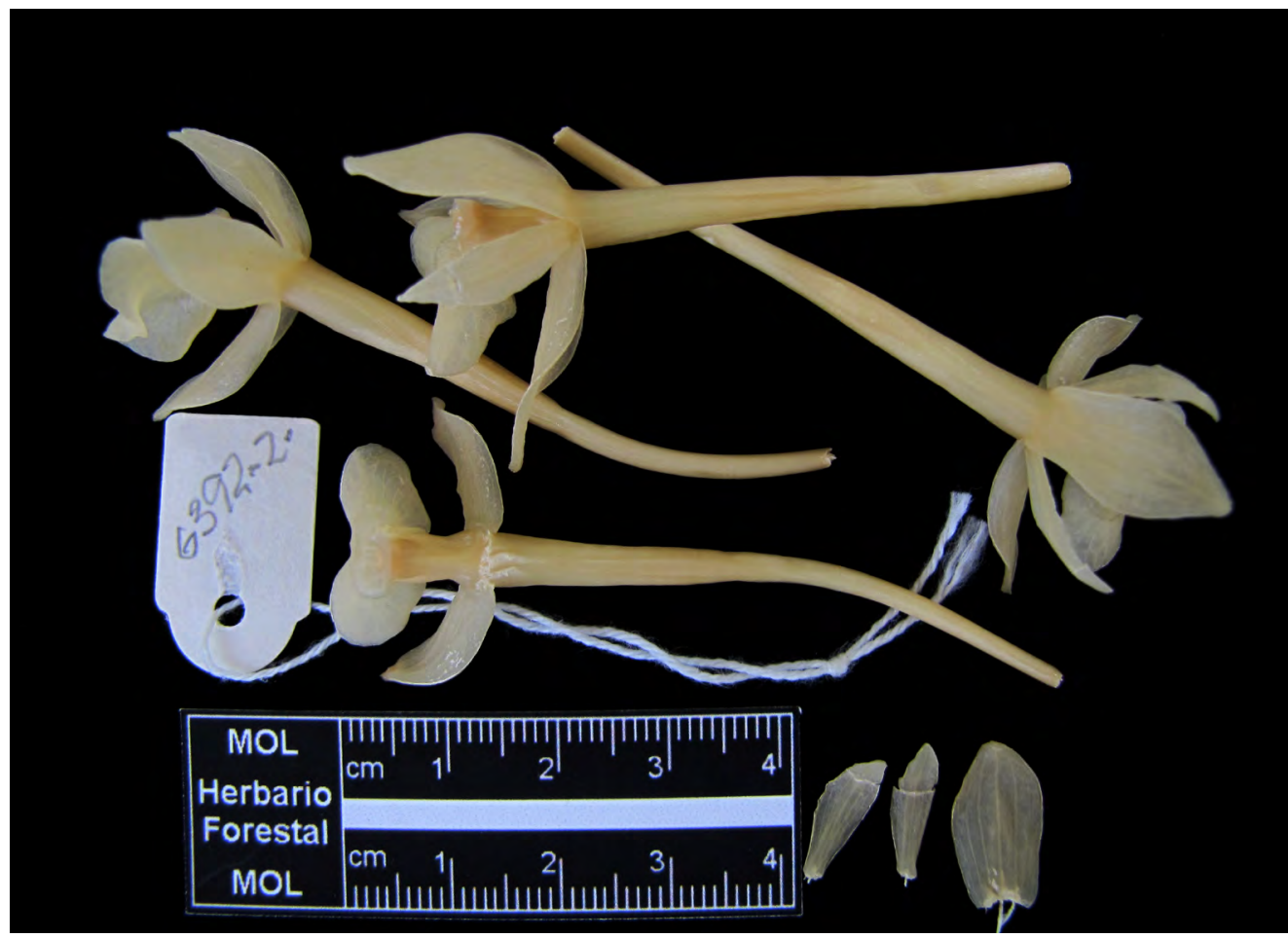

Figure 18. Epidendrum pseudapaganum D.E.Benn. \& Christenson. Lectotype at MOL (Bennett 6392-2 in spirit). Photo: D. Trujillo. 


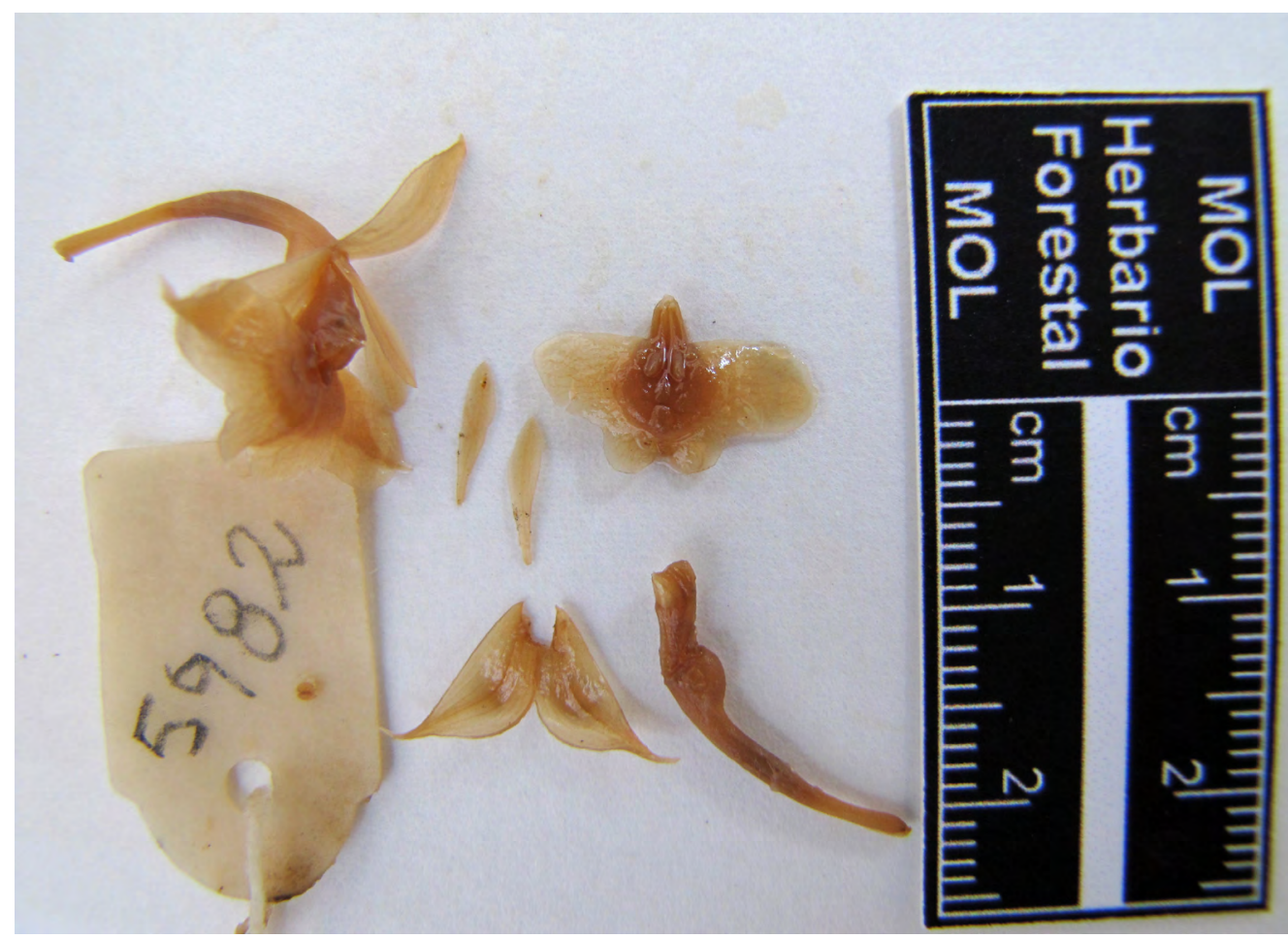

Figure 19. Epidendrum pseudopolystachyum D.E.Benn. \& Christenson. Holotype at MOL (Bennett 5982 in spirit). Photo: D. Trujillo.

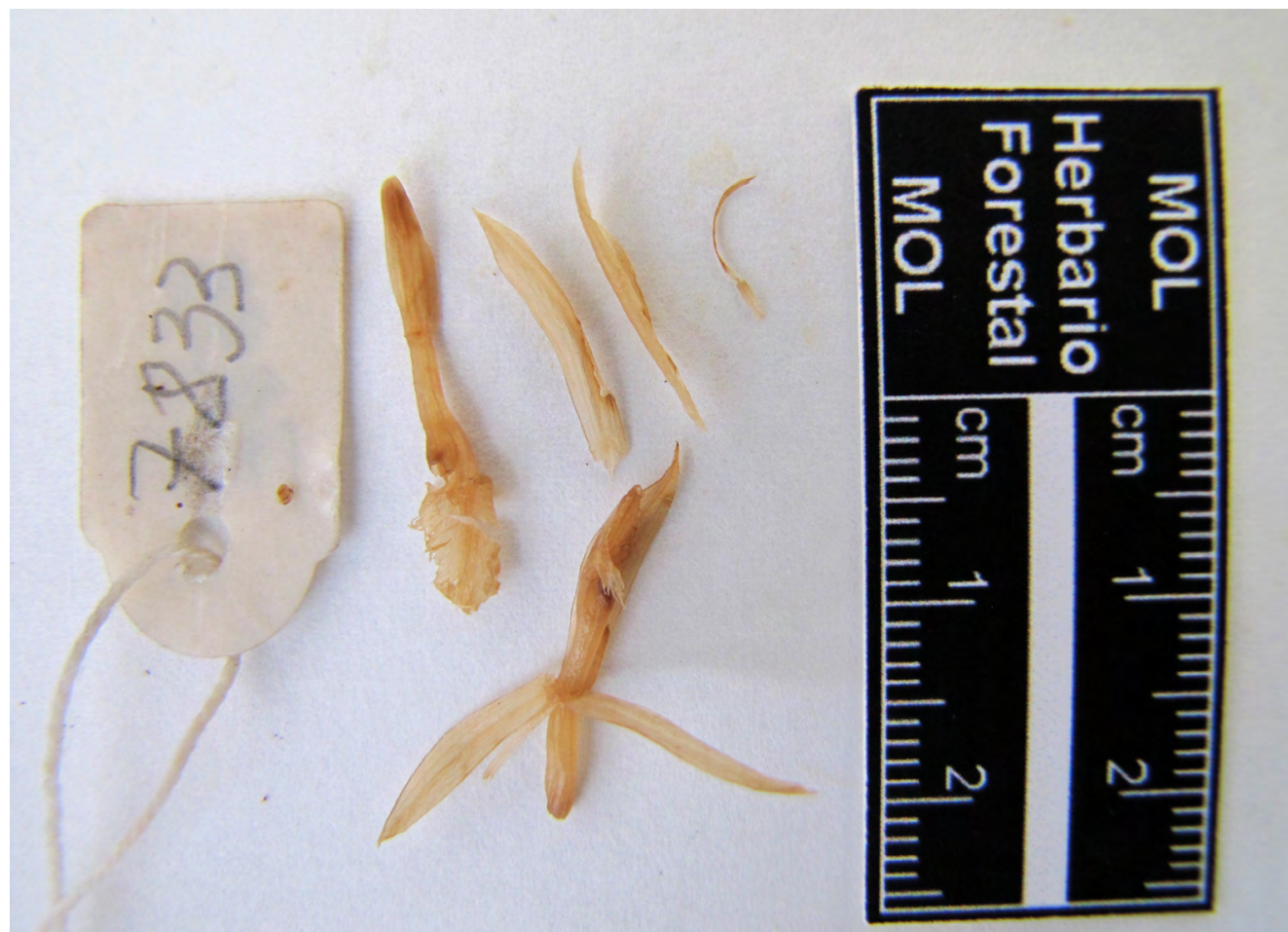

Figure 20. Epidendrum ruizlarreanum D.E.Benn. \& Christenson. Holotype at MOL (Bennett 7833 in spirit). Photo: D. Trujillo. LANKESTERIANA 14(1), April 2014. (C) Universidad de Costa Rica, 2014. 


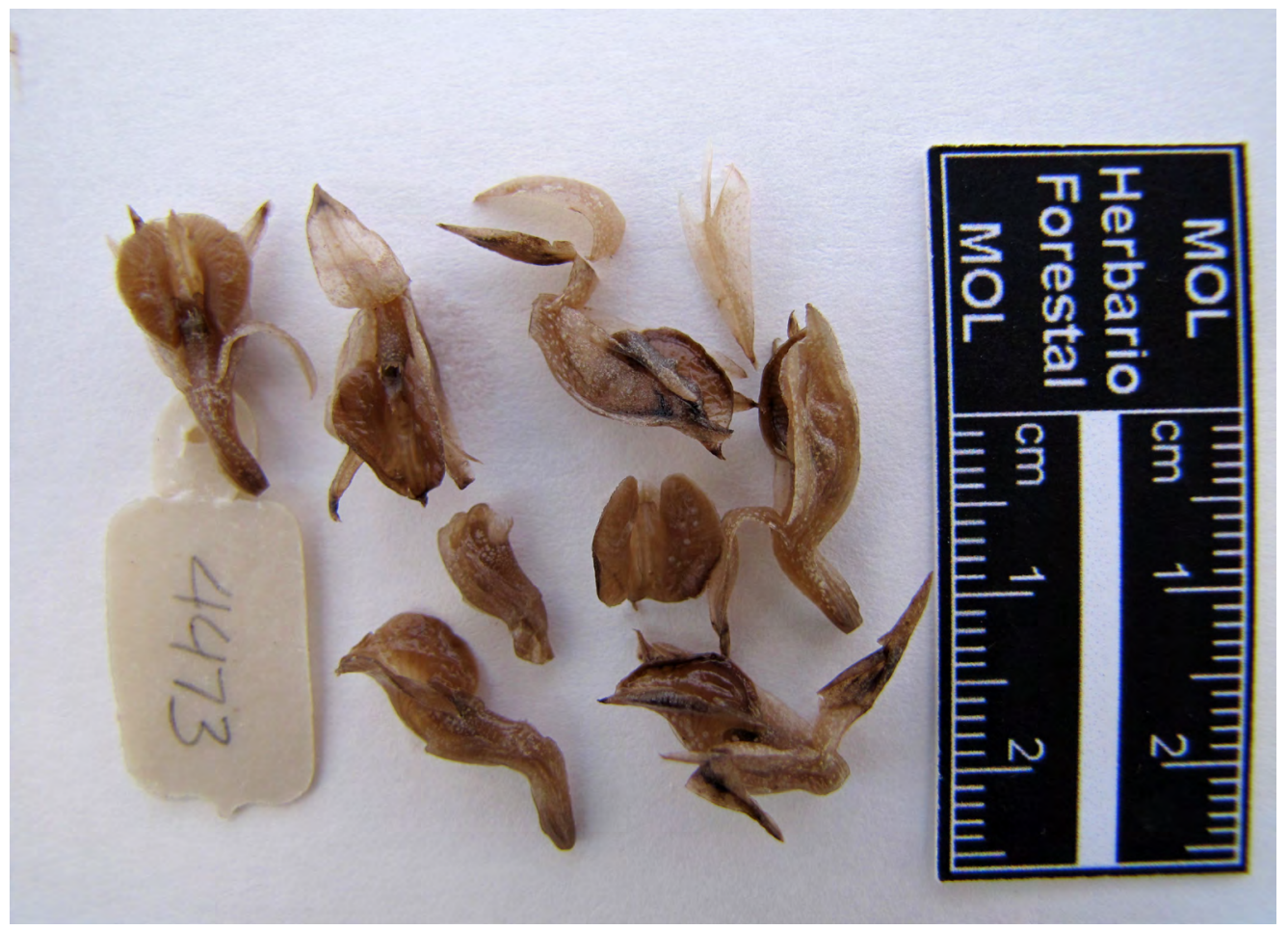

FIGURE 21. Epidendrum schizoclinandrium D.E.Benn. \& Christenson. Holotype at MOL (Bennett 4473 in spirit). Photo: D. Trujillo.

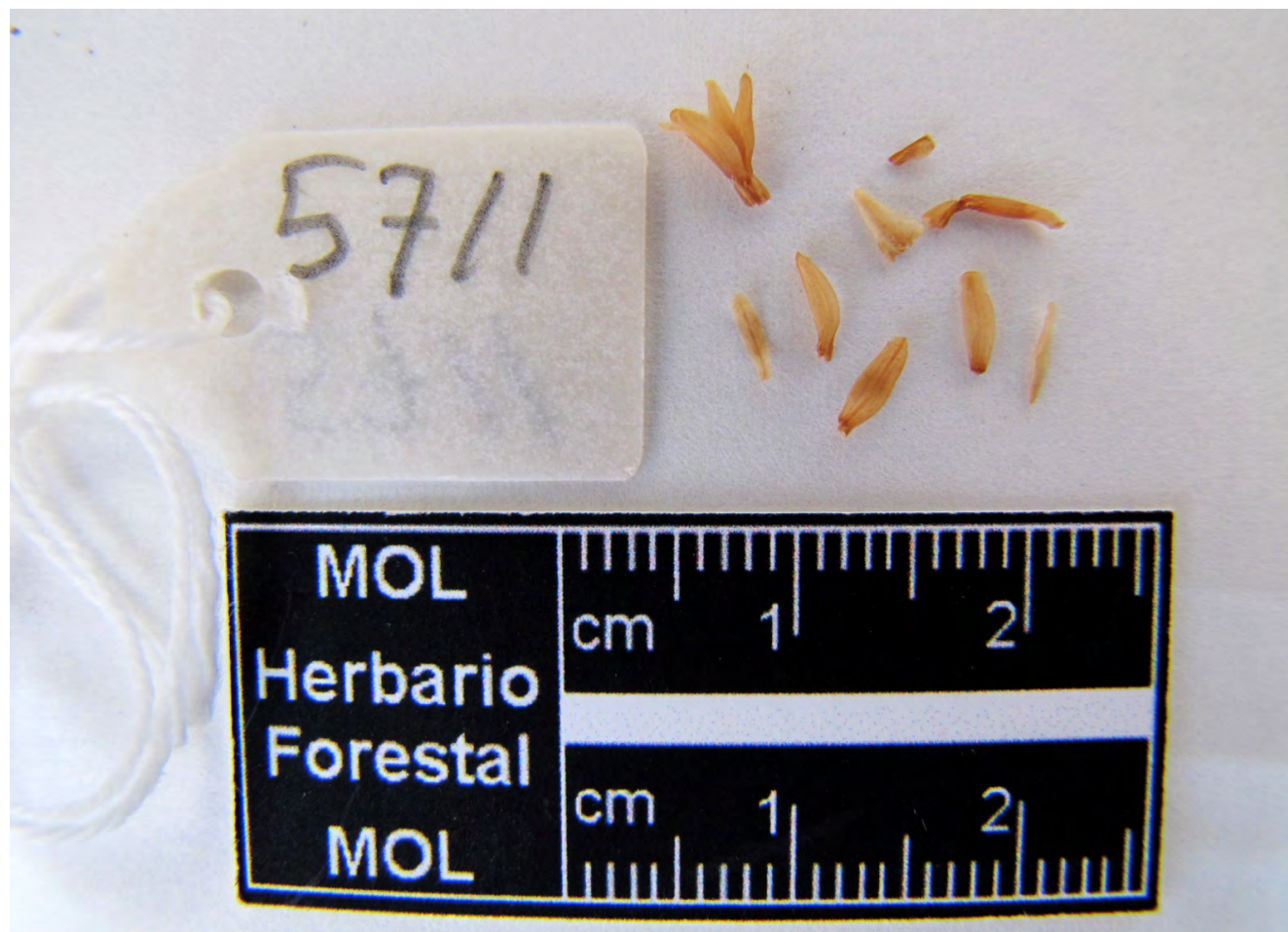

FiguRE 22. Epidendrum uncinatum D.E.Benn. \& Christenson. Holotype at MOL (Bennett 5711 in spirit). Photo: D. Trujillo. 


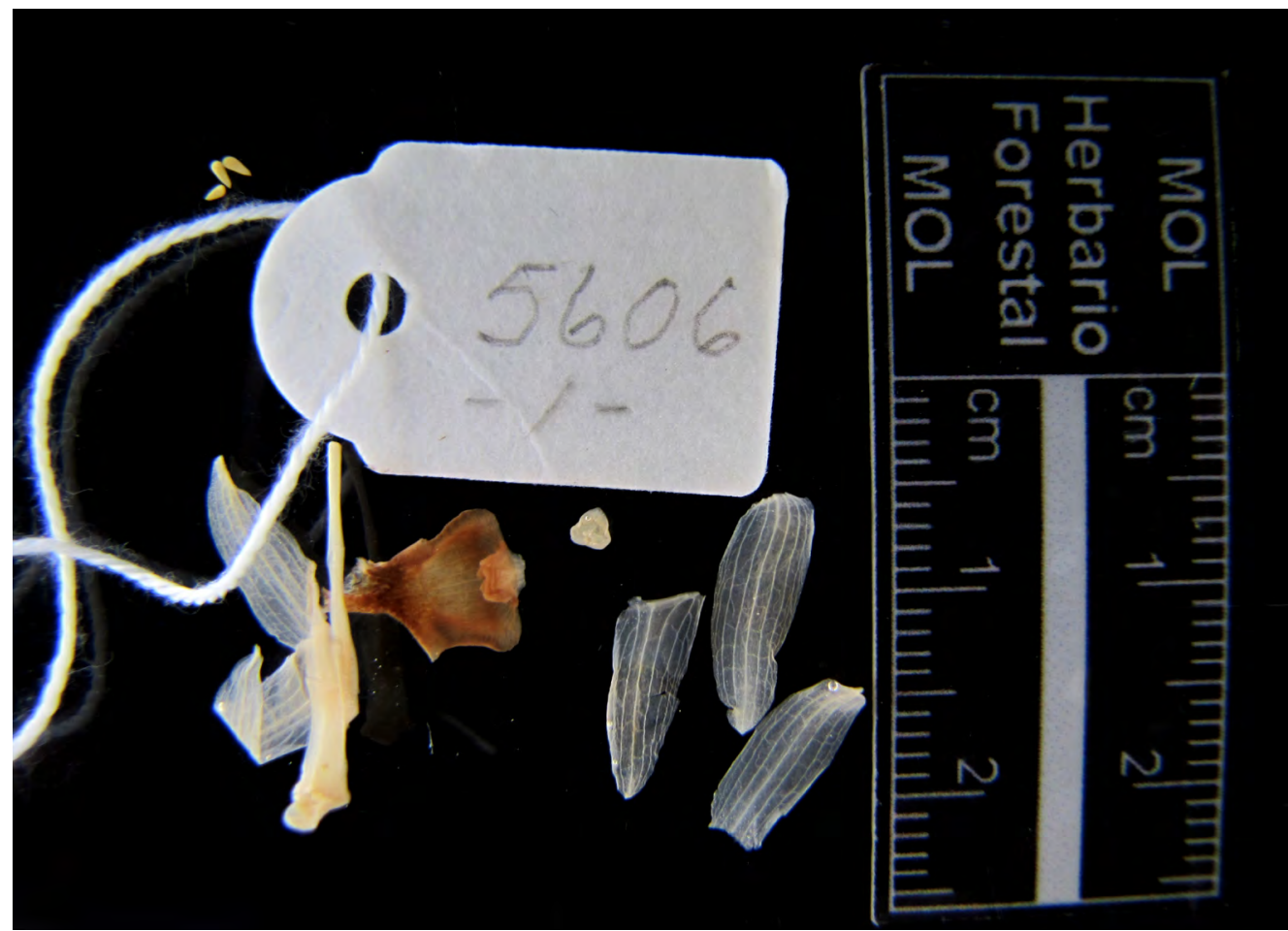

FiguRE 23. Kefersteinia benvenathar D.E.Benn. \& Christenson. Lectotype at MOL (Bennett 5606-1 in spirit). Photo: D. Trujillo.

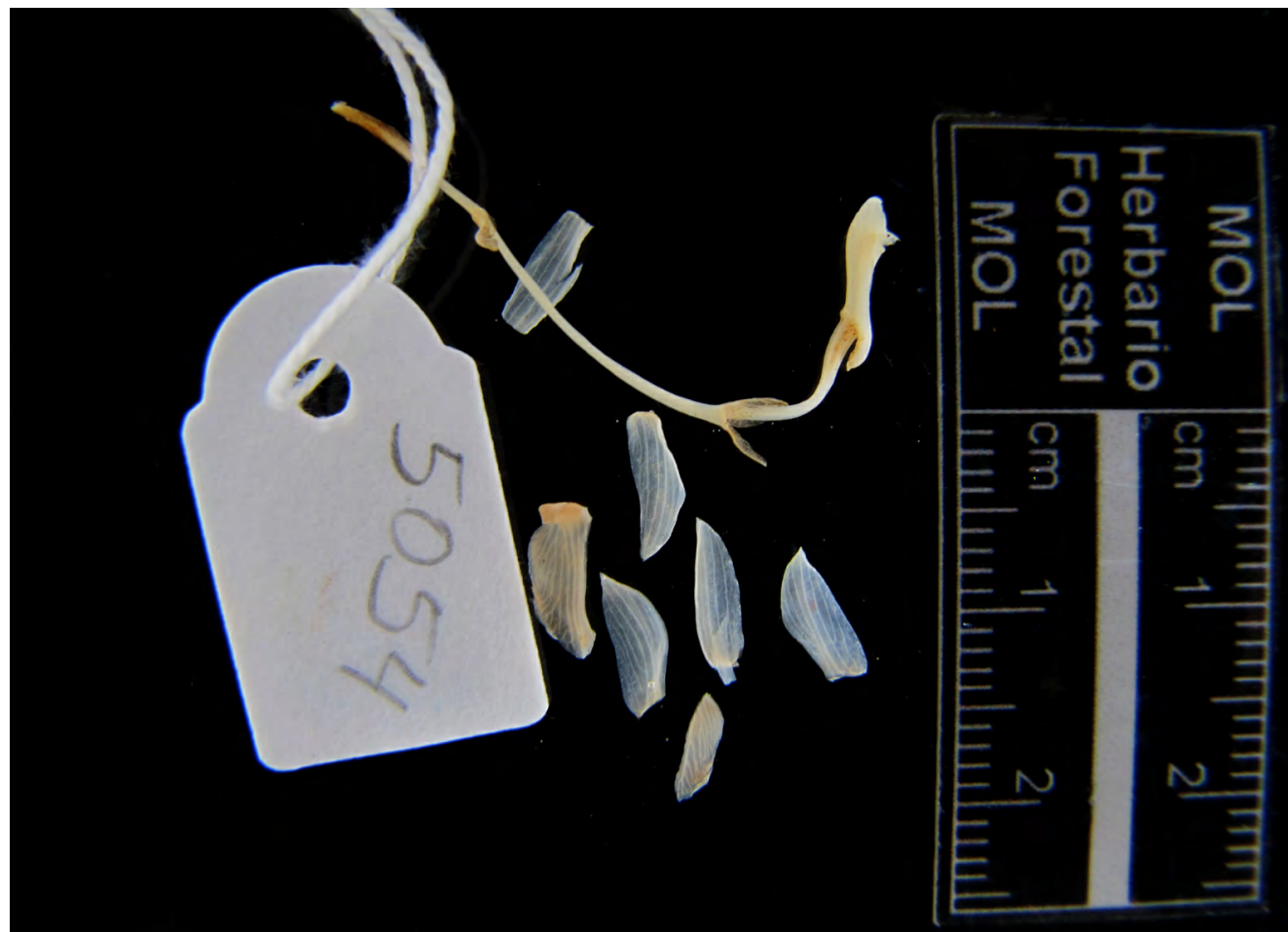

Figure 24. Kefersteinia licethyae D.E.Benn. \& Christenson. Lectotype at MOL (D. Bennett 5054 in spirit). Photo: D. Trujillo. LANKESTERIANA 14(1), April 2014. (c) Universidad de Costa Rica, 2014. 
now Sudamerlycaste diastasia (D.E.Benn. \& Oakeley) Archila.

The holotype was deposited at MOL by Bennett on 2001 and never at K. The type specimens were prepared on March 20, 1999.

Kefersteinia aurorae D.E.Benn. \& Christenson, Brittonia 46: 233. 1994.

TYPE: Peru, Junin, Chanchamayo, Kivinaki, N slope above Rio Perene, 1 Sep 1993, O. del Castillo ex Bennett 5516. Holotype: NY!; [Isotype: MOL-spirit (in part), see below]. Paratype: Peru, Junin, Tarma, Contaypaccha, 22 Apr 1992, O. del Castillo ex Bennett 5550. Paratype: according to the protologue at USM, now deposited at MOL-spirit (mixed), [see below].

Flowers of Bennett 5516 and Bennett 5550 mixed in a single jar were found in the Bennett's spirit collection at MOL; i.e., the isotype and paratype specimens are mixed. In the jar there are two dissected flowers and one intact flower. The illustration of $K$. aurorae for the original publication was prepared based on Bennett 5516; therefore the dissected flowers correspond to the isotype.

Kefersteinia benvenathar D.E.Benn. \& Christenson, Brittonia 46: 235. 1994.

TYPE: Peru, Pasco, Oxapampa, Puerto Bermúdez, Río Lorenzo, 4 Jun 1992, O. del Castillo ex Bennett Bennett 5606. Holotype: USM, lost. LeCTOTYPE here designated: Peru, without locality data [probably same as in the protologue], Bennett 5606-1 (MOLspirit; Fig. 23).

The holotype was not found in any Peruvian herbarium. Bennett 5606-1 in spirit in the Bennett collection at MOL consists of a dissected flower. The Table Records of the illustrated Bennett's specimens indicates that the plate of Kefersteinia benvenathar (LAM-789) was based on Bennett 5606-1. However this specimen is not cited in the protologue. As no cited specimen exists, Bennett 5606-1 in spirit is chosen here as the lectotype (ICN. Art. 9.12).

Kefersteinia candida D.E.Benn. \& Christenson, Brittonia 46: 238. 1994.
TYPE: Peru, Junin, Tarma, District of Huasahuasi, Caserio Santa Rosa, 21 Dec 1992 [28 Nov 1992, in error], O. del Castillo ex Bennett 5922. Holotype: according to the protologue at USM, now deposited at: NY!. Paratype: Peru, Junin, Jauja, Dist. Monobamba, Sector Cedrulla, 20 Sep 1993, Bennett 6316-4. Paratypes: NY!, [MOL-spirit].

Kefersteinia delcastilloi D.E.Benn. \& Christenson., Brittonia 46: 32. 1994.

TYPE: Peru, Dept. Junin, Prov. Chanchamayo, above Puerto Yurinaki, 1050 m, 7 July 1991, O. del Castillo ex D. Bennett 5113. Holotype: NY!.

The illustration voucher of Kefersteinia delcastilloi in the original publication is based upon Bennett 5113-1 (see legend of Fig. 6 on page 33). However this specimen was not cited in the text. A herbarium specimen of Bennett 5113-1; prepared on February 29, 1992, was located at NY (this specimen was erroneously designated as the holotype). A dissected flower in spirit of Bennett 5113-1 was located at MOL.

Kefersteinia licethyae D.E.Benn. \& Christenson, Brittonia 46: 34. 1994.

TYPE: Peru, Pasco, Oxapampa, Caserio Eneñas, between Villarica and Cacazu, 1200 m, 16 April 1991, O. del Castillo ex D. Bennett 5054. Holotype: NY, lost; [Isotype: MOL-spirit, here designated as LECTOTYPE]. (Fig. 24).

The holotype was not found at NY (T. Zanoni, pers. comm.). An extant isotype in spirit found in the Bennett collection at MOL is chosen here as lectotype (ICN. Art. 9.12).

Kefersteinia salustianae D.E.Benn. \& Christenson, Brittonia 46: 37. 1994.

TYPE: Peru, Junin, Chanchamayo, Tirol, $7 \mathrm{~km}$ E of San Ramon, 1200 m, 15 Mar 1992, S. Castro ex D. Bennett 5455. Holotype: NY!.

Two additional specimens of Bennett 5455 are in the Bennett collection at MOL: one pressed and one in spirit. The herbarium specimen was prepared on April 28, 1993; which disagrees with the date given in the protologue; therefore it is not an isotype. The specimen 
in spirit, consisting of a dissected flower, does not have the date of preparation on the label.

An additional herbarium specimen Bennett 5455 found at NY was prepared on May 9, 1992 and was also erroneously designated as the holotype.

Kefersteinia villenae D.E.Benn. \& Christenson, Brittonia 46: 241. 1994.

TYPE: Peru, San Martin, Moyobamba, near Pacaysapa, 31 Oct 1992, R. Villena \& B. Collantes ex Bennett 5699-1 [Bennett 5699, in error]. Holotype: NY!; Isotype: according to the protologue at USM, now deposited at MOL-spirit (x2).

The labels of the type specimens indicate that the correct collection number is Bennett 5699-1. Therefore the original type citation in the protologue is erroneous and here is corrected.

Kefersteinia villosa D.E.Benn. \& Christenson, Lindleyana 13: 51. 1998.

TYPE: Peru, Junin, Chanchamayo, Arcopunco, above Quebrada Seca, 2500 m, Leg. O del Castillo, 20 June 1992, flowered in cultivation 28 Aug 1993, Bennett 5609. Holotype: NY, lost; Isotype: USM, lost. Lectotype here designated: Peru, Junin, Prov. Chanchamayo, Cerro Arcopunco, 2500 m, 5 Sept 1992, O. del Castillo, D. Bennett 5609-3 (NY; Isolectotype: MOL-spirit).

No type specimen was found at NY (T. Zanoni, pers. comm.) nor at USM. However, three specimens (original material) of Kefersteinia villosa with two different suffixes (clones) were found in two herbaria. A herbarium specimen of Bennett 5609-3 is at NY with the following annotation: "sp. nov.?". Two specimens in spirit are in the Bennett collection at MOL: Bennett 5609-3 and Bennett 5609-4. The Table Records of the Bennett's illustrated specimens indicates that the illustration of the Kefersteinia villosa was based on Bennett 5609-4. However, neither Bennett 5609-3 nor Bennett 5609-4 is cited in the protologue.

As no cited specimens exist, the lectotype is chosen from among uncited specimens (ICN. Art. 9.12). The specimen here chosen as lectotype is the herbarium specimen of Bennett 5609-3.
Lepanthes caveroi D.E.Benn. \& Christenson, Icon. Orchid. Peruv.: t. 670. 2001.

TYPE: Peru, Amazonas, Condorcanqui, near border post PV-3, $1200 \mathrm{~m}$, M. Cavero B. 1645. Holotype: originally deposited at Herb. Bennettianum, now at MOL.

Bennett kept the herbarium specimen of $M$. Cavero B. 1645 unmounted in his personal collection between newspaper sheets with the collection number written on them.

Lepanthes leonii D.E.Benn. \& Christenson, Icon. Orchid. Peruv.: t. 673. 2001. nom. illeg., non Lepanthes leonii C.Schweinf. Contr. Ocas. Mus. Hist. Nat. Colegio “'De Le Salle” 8: 362.1946.

TYPE: Peru, Ayabaca, $20 \mathrm{kms}$ SE of the city of Ayabaca near Olleros, Comunidad Cujaca in the quebrada Mangos, 1500 m, Dec 1993 [date of preparation 11 Oct 1994], M. León M. ex Bennett 6577. Holotype: originally deposited at Herb. Bennettianum, now at MOL.

The living specimen of M. León M. ex Bennett 6577 was collected on December 1993, but the herbarium specimen was prepared on October 11, 1994.

Lepanthes oxapampaensis D.E. Benn. \& Christenson, Icon. Orchid. Peruv.: t. 675. 2001.

TYPE: Peru, Pasco, Oxapampa, Villarica, Villarica, Canal de Piedra, 24 Aug 1994 [date of preparation 7 Nov 1994], O. del Castillo ex Bennett 6736. Holotype: originally deposited at Herb. Bennettianum, now at MOL.

The living specimen was collected on August 24, 1994 and bloomed from September to November (as indicated in the protologue). The herbarium specimen was prepared on November 7, 1994.

Lockhartia genegeorgei D.E.Benn. \& Christenson, Lindleyana 13: 53. 1998.

TYPE: Peru, Huanuco, Leoncio Prado, 3 kms SW of Cueva de Pavas, alturas de Huachipa, leg. E. Jara P., Sept 1992, Bennett 5199. Holotype: NY, lost; Isotype: USM, lost. Paratype: Peru, Huanuco, Leoncio Prado, same general locality as the type, leg. E. Jara P. Oct. 
1995, Bennett 7321. Patatype: USM, lost, [MOLspirit, here designated as LeCTOTYPE] (Fig. 25).

Six herbarium specimens of Bennett 5199 (collection number designated as holotype in the protologue) with different suffixes and dates of preparation were found at four herbaria. None of them agrees with the date given in the protologue. They are: Bennett 5199-6 prepared on September 12, 1992 (NY!), Bennett 5199-13 prepared on October 23, 1991 (AMES), Bennett 5199-13 prepared on January 5, 1992 (NY!), Bennett 5199-19 prepared on December 20, 1991 (FLAS), Bennett 5199-24 prepared on January 5, 1992 (NY!) and Bennett 5199-24 prepared on March 8, 1992 (MOL). These specimens are not duplicates (isotypes) of the holotype because they were not made as a single gathering (ICN. Art. 8.2). However, they constitute part of the original material. When an isotype is not extant, the lectotype must be chosen from among the paratypes (ICN. Art. 9.12). The specimen here chosen as lectotype is Bennett 7321; the paratype in spirit found in the Bennett collection at MOL.

Lockhartia lepticaula D.E.Benn. \& Christenson, Icon. Orchid. Peruv.: t. 678. 2001.

TYPE: Peru, Huanuco, Leoncio Prado, above Cueva de Las Pavas, 950 m, 10 Nov 1991, E. Jara P. ex Bennett 5326. Holotype: Herb. Bennettianum, lost. Lectotype here designated: Peru, without collection data [probably same as in the protologue], Bennett 5326-2 (MOL-spirit, in part) [see below] (Fig. 26).

The holotype was not found in the Bennett collection at MOL. However, (three) flowers in spirit of Bennett 5326-1 and Bennett 5326-2 mixed in a single jar were found. One of the flowers is dissected. The Table Records of the illustrated Bennett's specimens indicates that the illustration of Lockhartia lepticaula was prepared based on Bennett 5326-2. After comparing with the illustration, the dissected flower is interpreted to represent Bennett 5326-2. However, neither Bennett 5326-2 nor Bennett 5326-1 is cited in the protologue.

As no cited specimen exists, the lectotype is chosen from among uncited specimens (ICN. Art. 9.12). The specimen here chosen as lectotype is Bennett 5326-2.
Lockhartia schunkei D.E.Benn. \& Christenson, Icon. Orchid. Peruv.: t. 486. 1998.

TYPE: Peru, Tumbes, Zarumilla, $10 \mathrm{~km}$ East of El Caucho, Bosque Nacional de Tumbes, 580 m, 15 Mar 1993, M. Cavero B. 314 ex Bennett 6563. Holotype: MOL, lost; Isotype: USM, lost, [MOL-spirit, here designated as LECTOTYPE] (Fig. 27).

The type specimen was not found at MOL (not in the Bennett collection) nor at USM. An extant isotype in spirit found in the Bennett's spirit collection (now at MOL) is here designated as lectotype.

Lockhartia tuberculata D.E.Benn. \& Christenson, Brittonia 46: 241. 1994.

TYPE: Peru, Junin, Chanchamayo, headwaters of Rio Toro near Puente San Felix, 29 Feb 1992, O. del Castillo ex Bennett 5403. Holotype: USM, lost; [Isotypes: NY, here designated as LECTOTYPE; Isolectotype: MOLspirit].

The holotype was not found at any Peruvian herbarium However, two specimens of Bennett 5403 (isotypes) were found at different herbaria; a herbarium specimen at NY and a specimen in spirit in the Bennett collection at MOL. In absence of the holotype, a lectotype is designated here (ICN. Art. 9.2). The most complete isotype specimen deposited at NY is here designated as lectotype (ICN. Art. 9.12).

Lycaste diastasia D.E.Benn. \& Oakeley, Brittonia 46: 243. 1994.

TYPE: Peru, Huanuco, Leoncio Prado, along road to Monzon, 10 Jul 1987, E. Jara P. ex Bennett 3797. Holotype: USM, lost. Paratype: Peru, San Martin, San Martin, along road to Lamas, 12 Jul 1989, R. Villena ex D. Bennett 4548 Paratype: USM, lost [see below]. LECTOTYPE here designated: Peru, Huanuco, Leoncio Prado, uncertain locality, 750-950, 23 June 1990, E. Jara sn, D. Bennett 3797 (MOL).

Basionym of: Sudamerlycaste diastasia (D.E.Benn. \& Oakeley) Archila, Revista Guatemal. 5: 79. 2002.

The holotype was not found in any Peruvian herbarium. Two herbarium specimens of Bennett 3797 (same collection number that the holotype) were found in the Bennett collection at MOL. They were prepared: 
February 20, 1987 and June 23, 1990, respectively. However neither of the dates of preparation agrees with the date given in the protologue.

A herbarium specimen of Bennett 4548 (same collection number that the paratype) prepared on July 13, 1996 was also found in the same collection at MOL; but the date of preparation also disagrees with the date given in the protologue.

As no cited specimens exist, the lectotype is chosen from among uncited specimens (ICN. Art. 9.12). The specimen here chosen as lectotype is the herbarium specimen of Bennett 3797 prepared on Jun 23, 1990; that agrees with the species description.

Lycaste jarae D.E.Benn. \& Christenson, Orchid Digest 60: 14. 1996.

TYPE: Peru, Huanuco, Leoncio Prado, $6 \mathrm{~km}$ SE of Tingo Maria, 1100 m, 28 Aug. 1993, E. Jara P. ex Bennett 6433. Holotype: USM, lost; Isotype: NY, lost. Lectotype here designated: Peru, Huanuco, Leoncio Prado, National Park La Bella Durmiente, 1000 m, 4 Sept 1993, E. Jara s.n. ex D. Bennett 6433 (NY).

Synonym of: Sudamerlycaste peruviana (Rolfe) Archila, proposed by Archila, Revista Guatemal. 6: 4 2003.

The holotype was not found at USM. Three specimens of Bennett 6433 were found in the Bennett collection at MOL: two in spirit and one pressed prepared on October 13, 1994. The locality data of the herbarium specimen agrees with that given in the protologue, but not the date of preparation.

An additional herbarium specimen of Bennett 6433 prepared on September 4, 1993 was found at NY. This specimen was designated as the holotype; however the date of preparation and locality disagrees with that given in the protologue.

In absence of the holotype, a lectotype is designated here among the original material found at NY and MOL (ICN. Art. 9.12). The specimen here chosen as lectotype is the pressed specimen conserved at NY.

Macroclinium aurorae Dodson, Icon. Pl. Trop., II, 1: t. 97.1989.

TYPE: Peru, Junin, Satipo, along road to Huancayo, 750 m, Bennett 3479. Holotype: MO, not found;
[Isotype: MOL-spirit, here designated as LectoTyPe] (Fig. 28).

The holotype was not found at MO. An extant isotype, a whole plant is preserved in spirit found in the Bennett collection at MOL, is here chosen as lectotype.

Macroclinium christensonii D.E. Benn., Brittonia 46: 249. 1994.

TYPE: Peru, Junin: Chanchamayo, Gran Playa Centro, 4 Aug 1991, O. del Castillo ex Bennett 5160: Holotype: NY!; [Isotype: MOL-spirit].

Macroclinium villenarum D.E.Benn., Lindleyana 7: 80. 1992.

TYPE: Peru, Department of San Martin, Prov. of Moyobamba: below the city along the Mayo River in low trees, 820 m, 15 Mayo 1990, R. and M. Villena sub Bennett 4978. Holotype: according to the protologue at USM, now deposited at MOL[-spirit] (Fig. 29).

The whole plant is preserved in spirit.

Masdevallia mijahuangae D.E. Benn., Publ. Mus. Hist. Nat. Univ. Nacion. Mayor San Marcos, Bot. 37: 1. 1993.

TYPE: Peru, Junín, Prov. Tarma, heights above Huasahuasi, ca. 3000 m. 3 Aug. 1992, F. Mijahuanga s.n. ex Bennett 5678. Holotype: USM, lost [See below]. Lectotype here designated: Peru, Junin, Prov. Tarma, 3000 m. 12 Aug. 1992, F. Mijahuanga s.n. ex Bennett 5678 (MOL).

Synonym of: Masdevallia cyclotega Königer, proposed by Luer in Monogr. Syst. Bot. Missouri Bot. Gard. 87: 815. 2002.

The holotype was not found at USM. Two specimens of Bennett 5678 are in the Bennett collection at MOL: one pressed and one in spirit. The herbarium specimen consists of a whole plant (with a flower) prepared on August 12, 1992, but this date disagrees with that given in the protologue. The specimen in spirit consists of a dissected flower that agrees with the illustration of the original publication, but the label does not indicate its date of preparation.

Both specimens at MOL represent the original 
material of Masdevallia mijahuangae; however neither of them has an annotation that indicates it is the holotype. Therefore, as there is not a clear holotype, a lectotype is designated here from among the specimens that comprise the original material (ICN. Art. 9.12); the specimen chosen is the most complete herbarium specimen.

Masdevallia oxapampaensis D.E. Benn. \& Christenson, Icon. Orchid. Peruv.: t. 684. 2001.

TYPE: Peru, Pasco, Oxapampa, Yanachaga-Chemillen [Llanachaga-Chemellin, in error], Rio Alberto sector, 1900-2000 m, 1 Feb 1995, O. del Castillo ex Bennett 6979. Holotype: originally deposited at Herb. Bennettianum, now at MOL[-spirit] (Fig. 30).

Bennett 6979 in spirit was found in the Bennett Collection at MOL; however, a pressed preparation was not located. The spirit specimen, a dissected flower that agrees with the illustration of the original publication is the holotype.

Maxillaria aurorae D.E.Benn. \& Christenson, Brittonia 47: 189. 1995.

TYPE: Peru, Huanuco, Leoncio Prado, Brunas, 1000 m, J. Guerra ex Bennett 5668. Holotype: NY, lost; [Isotype: MOL-spirit, here designated as LECTOTYPE] (Fig. 31).

The holotype was not found at NY (T. Zanoni, pers. comm.). An extant isotype in spirit found in Bennett's collection at MOL is here designated as lectotype (ICN. Art. 9.12).

A herbarium specimen of Bennett 5668-1 without locality data prepared on September 10, 1993 was also found in Bennett's collection at MOL. This specimen was cited as the illustration voucher of Maxillaria aurorae in the original publication (Fig. 5 on page 190).

Maxillaria azulensis D.E.Benn. \& Christenson, Icon. Orchid. Peruv.: t. 687. 2001.

TYPE: Peru, Huanuco, Leoncio Prado, Cordillera Azul, 1400 m, E. Jara P. ex Bennett 5368. Holotype: originally deposited at Herb. Bennettianum, now at MOL.

The specimen was prepared on December 14, 1991.
There is not locality data on the label of the specimen.

Maxillaria bennettii Christenson, Brittonia 47: 189. 1995.

TYPE: Peru, Huanuco, Carpish Pass, 31 Oct 1986 [1 Nov 1986, in error], Bennett et al. 3657. Holotype: according to the protologue at USM, now deposited at MOL, part in spirit.

The label indicates that the specimen was collected on October 31, 1986.

Maxillaria bocazensis D.E.Benn. \& Christenson, Icon. Orchid. Peruv.: t. 689. 2001.

TYPE: Peru, Pasco, Oxapampa, District of Villarica, Cerro Bocaz, 1100 m, Nov 1994, J. Campoverde ex Bennett 6858. Holotype: Herb. Bennettianum [now at MOL], lost. Lectotype here designated: Peru, Pasco, Oxapampa, District of Villarica, 2000 m, 5 Dec 1994, J. Campoverde sn. (LAM-1102). Lectotype: MOL.

The type collection was not found in the Bennett collection at MOL. However, two specimens of a Maxillaria species collected by J. Campoverde labeled as "LAM-1102" were found: one pressed and one in spirit.

The Table Records of the illustrated Bennett's specimens indicates that the plate or Lamina "1102" was made based on the specimen Bennett 6858. Both specimens labeled as "LAM-1102" agrees with the description of Maxillaria bocazensis. The specimen in spirit is a dissected flower that agrees with the illustration of the original publication. The illustration was prepared on December 3, 1994, probably on this date the specimen in spirit was prepared. The pressed specimen was prepared on December 5, 1994, but this date disagrees with that given in the protologue.

Both specimens of "LAM 1102" represent the original material; however neither of them has an annotation that indicates it is the holotype. In absence of the Holotype, a lectotype is designated here (ICN. Art. 9.2). The specimen chosen as lectotype is the most complete (pressed) specimen.

Maxillaria burtonii D.E.Benn. \& Christenson, Icon. Orchid. Peruv.: t. 691. 2001.

TYPE: Peru, Pasco, Villarica, 5 kms S of Alto Ñaguza, 
1950 m, Jan 1993, J. Campoverde ex Bennett 6049. Holotype: originally deposited at Herb. Bennettianum, now at MOL[-spirit] (Fig. 32).

Bennett 6049 in spirit was found in the Bennett collection at MOL; however, a pressed preparation was not located. The spirit specimen, a dissected flower that agrees with the illustration of the original publication, represents the holotype.

Maxillaria caveroi D.E.Benn. \& Christenson, Lindleyana 13: 64. 1998.

TYPE: Peru, Amazonas, Condorcanqui, Meseta de Cerro Machinaz, 2100 m, Aug 1994, M. Cavero B. et al. 1639. Holotype: NY!; Isotypes: according to the protologue at USM, now deposited at $\operatorname{MOL}(\mathrm{x} 2)$, MOL-spirit.

The isotypes were deposited at MOL by Bennett in 2001 and were never at USM, the herbarium specimens were between newspaper sheets with the collection number written on them.

Maxillaria christensonii D.E.Benn., Brittonia 50: 187. 1998.

TYPE: Peru, Pasco, Oxapampa, 14 km W of Puerto Bermudez on rd. to Cerro San Matias, 1200 m, 27 Sep 1992, leg. O. del Castillo, in Bennett 5754. Holotype: NY, lost Lectotype here designated: Peru, Pasco, Oxapampa, Pto. Bermudez $14 \mathrm{~km}$ west, on Cerro San Matias, 1200 m. $11 \mathrm{Jul}$ 1994, leg. O. del Castillo, in Bennett 5754 (MOL).

The holotype was not found at NY (T. Zanoni, pers. comm.). The extant original material in the Bennett collection at MOL is here designated as lectotype (ICN. Art. 9.12). However its date of preparation disagrees with that given in the protologue.

Maxillaria edwardsii D.E.Benn. \& Christenson, Lindleyana 13: 68. 1998.

TYPE: Peru, Junin, Chanchamayo, exact locality not given, leg. O. del Castillo, Mar 1995, cultivated by E. Edwards, Bennett 7050. Holotype: according to the protologue at USM, now deposited at MOL[-spirit] (Fig. 33).

Synonym of: Maxillaria argyrophylla Poepp. \&
Endl. proposed by M.A. Blanco in Selbyana 31: 54. 2013.

Bennett 7050 in spirit was found in the Bennett collection at MOL; however, a pressed preparation was not located in any Peruvian herbarium. The spirit specimen, a dissected flower that agrees with the illustration of the original publication, represents $s$ the holotype.

Maxillaria foetida D.E.Benn. \& Christenson, Richardiana 9(2): 54-55. 2009.

TYPE: Peru, Cuzco, La Convención, District of Echarate, Cumpirusiato river basin, Shell Corporation helipad \# 23, 1245m, Oct 1998, M. Cavero ex Bennett 7847. Holotype: MOL[-spirit] (Fig. 34).

Basionym of: Inti foetida (D. Bennett \& Christenson) M.A. Blanco. Selbyana 31: 53. 2013.

Bennett 7847 in spirit was found in the Bennett collection at MOL. However, a pressed preparation was not located in any Peruvian herbarium. The flowers in spirit agree with the species description; therefore the specimen represents the holotype.

Bennett \& Christenson; in the protologue of Maxillaria foetida, stated: "We illustrated this species for Peru earlier as M. chartacifolia (Icon. Orchid. Peruv. pl. 97. 1993)"; and they published again that cited illustration. However, they did not indicate the voucher for the illustration.

In the publication of Maxillaria chartacifolia Ames \& C. Schweinf. in the Icon. Orchid. Peruv. pl. 97. 1993, the illustration voucher is Bennett 4130; however, this specimen is not cited among the specimens examined. For examined specimens; Bennett 4064 is cited, but this specimen represent a different species (flowers in spirit were located in the Bennett collection at MOL). A herbarium specimen of Bennett 4130 was found at MOL and agrees with the illustration.

Maxillaria frechettei D.E.Benn. \& Christenson, Icon. Orchid. Peruv.: t. 694. 2001.

TYPE: Peru, Huanuco, Huanuco, below Carpish Pass on the drier side of the pass, $2400 \mathrm{~m}, 2$ Nov 1986, $D$. Bennett, A. Bennett \& M. Arias 3678 [3876, in error]. Holotype: Herb. Bennettianum [now at MOL] lost. LECTOTYPE here designated: Peru, without locality 


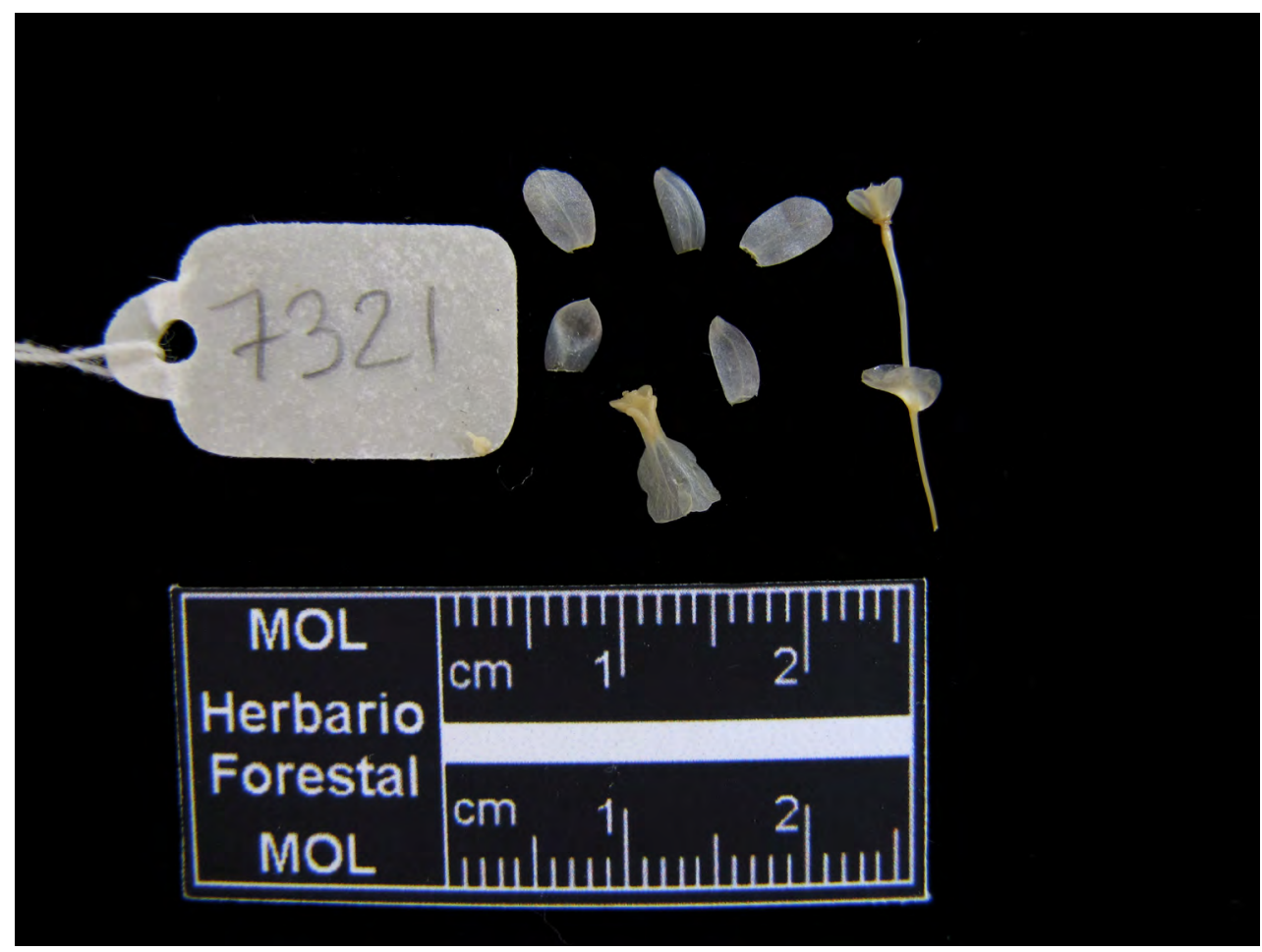

FiguRE 25. Lockhartia genegeorgei D.E.Benn. \& Christenson. Lectotype at MOL (Bennett 7321 in spirit). Photo: D. Trujillo.

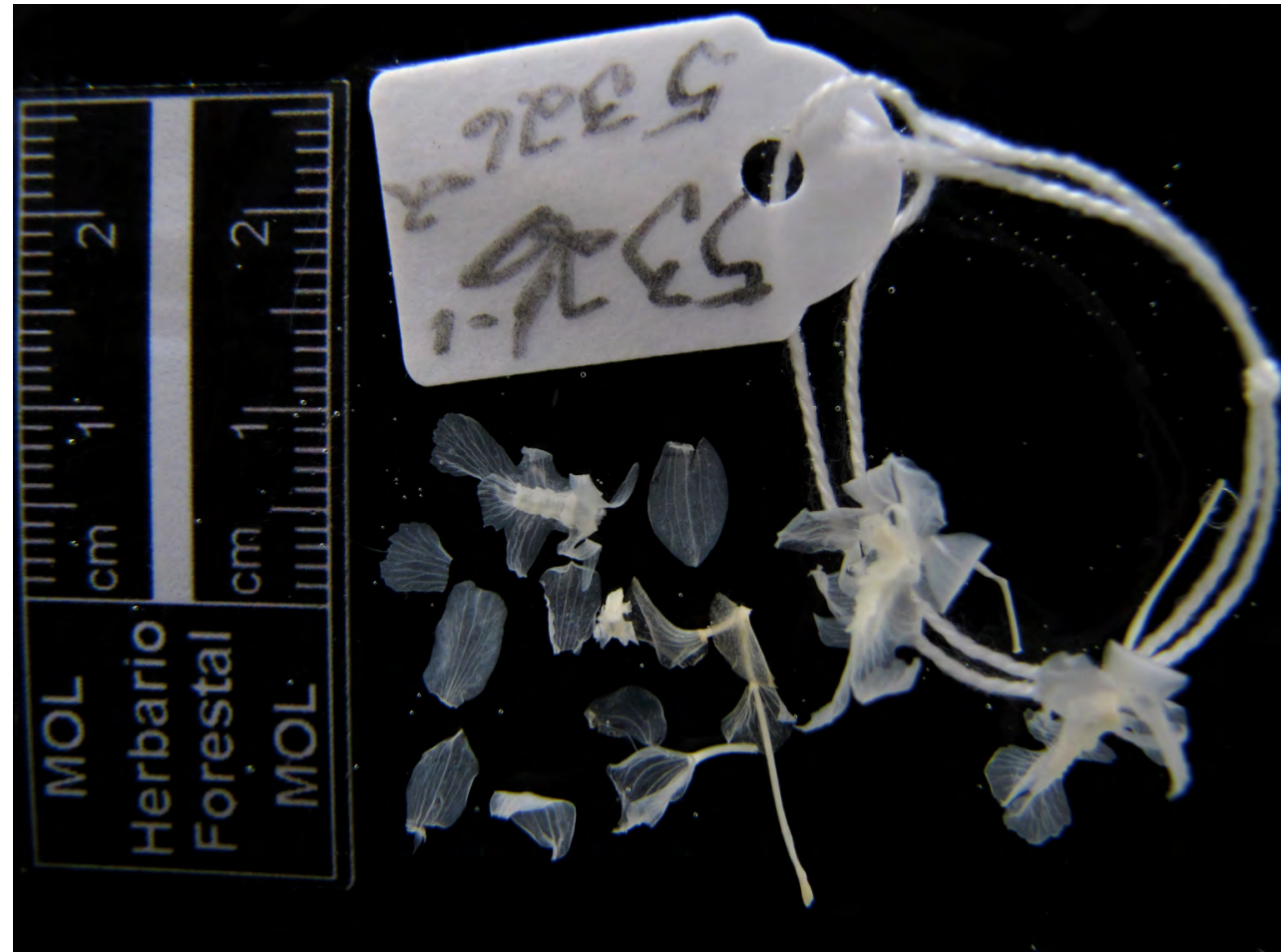

FIgure 26. Lockhartia lepticaula D.E.Benn. \& Christenson. Lectotype at MOL (dissected flower, Bennett 5326-2 in spirit). Photo: D. Trujillo. 


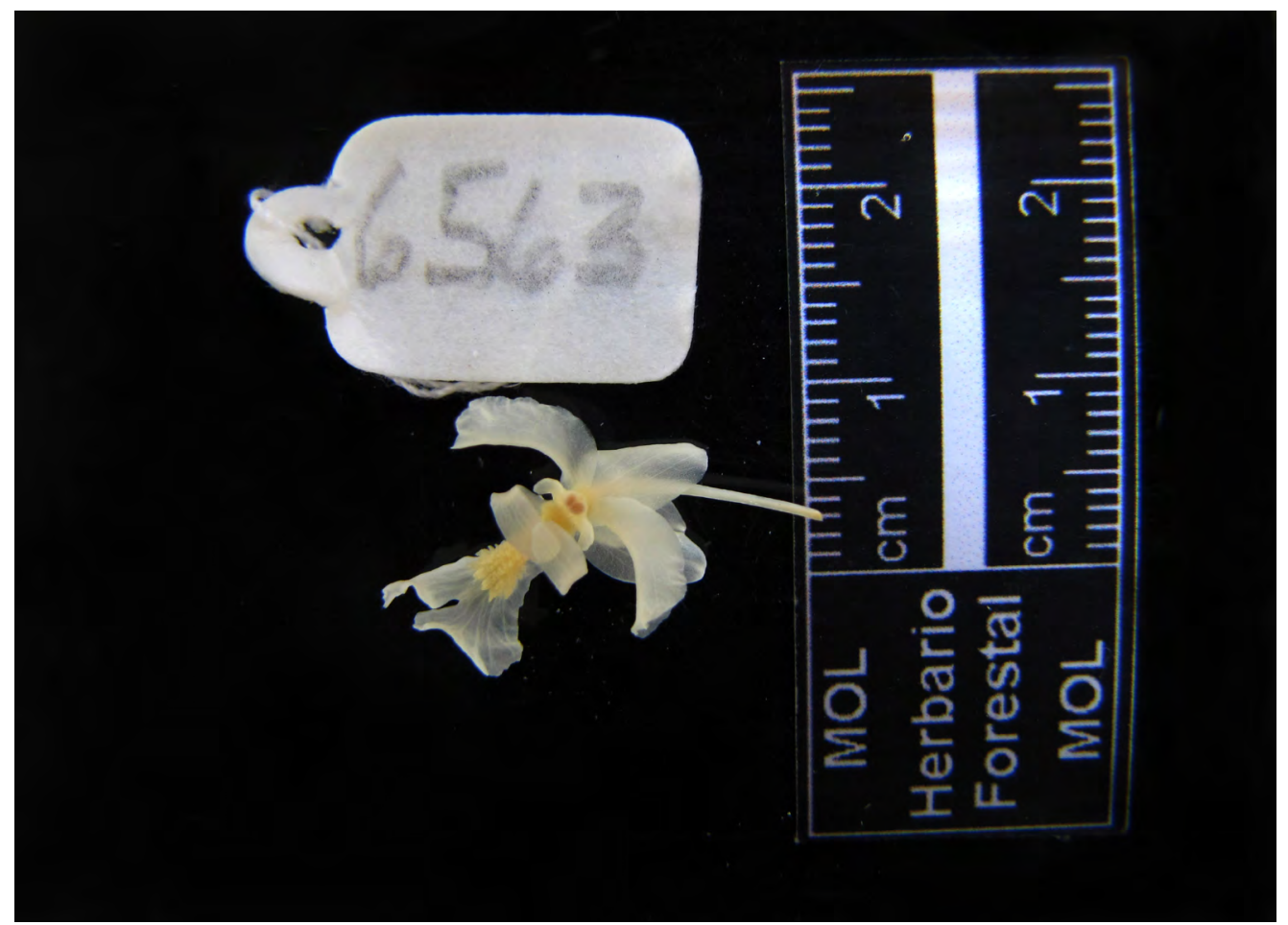

Figure 27. Lockhartia schunkei D.E.Benn. \& Christenson. Lectotype at MOL (Bennett 6563 in spirit). Photo: D. Trujillo.

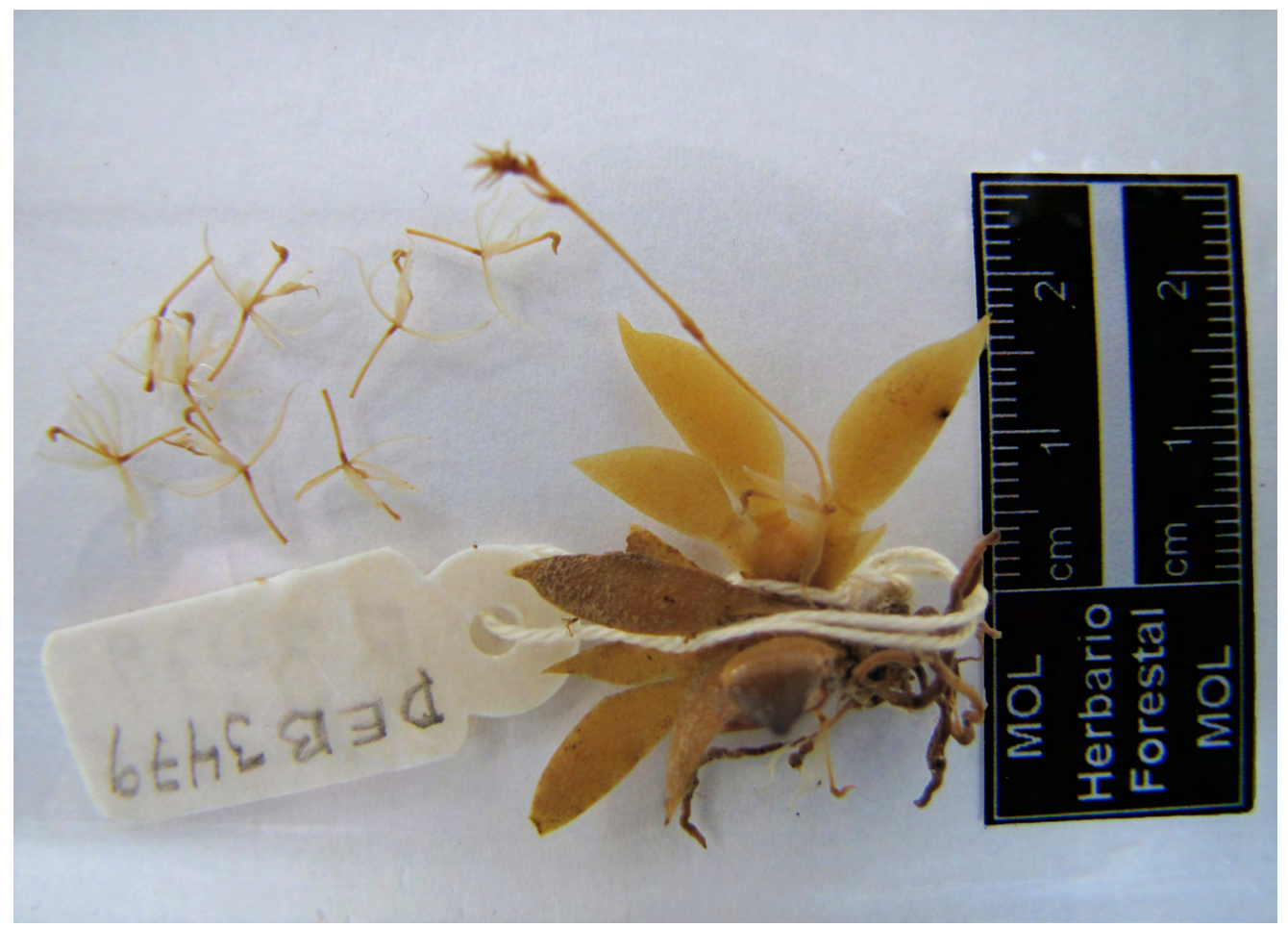

FiguRE 28. Macroclinium aurorae Dodson. Lectotype at MOL (Bennett 3479 in spirit). Photo: D. Trujillo. 


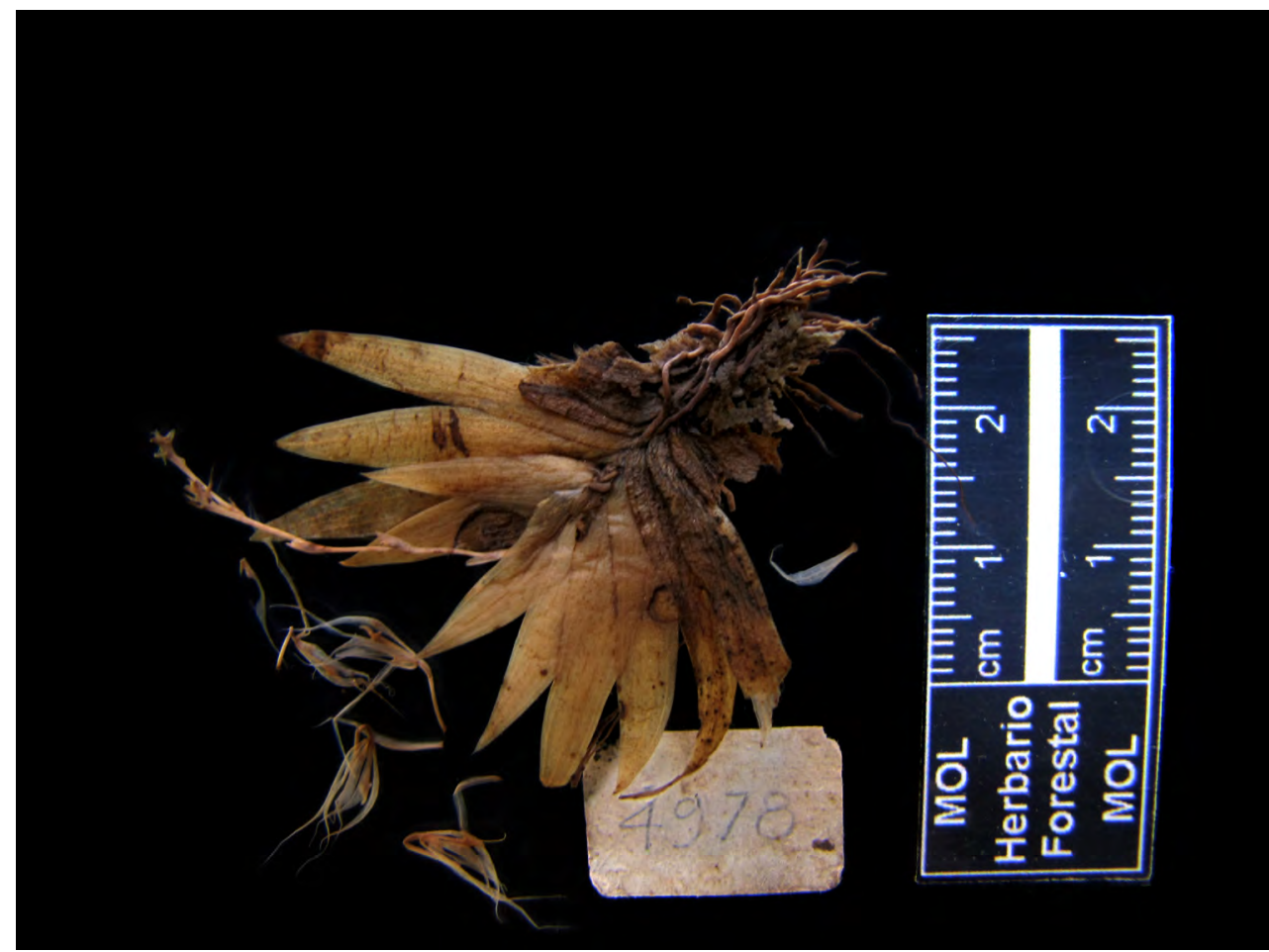

Figure 29. Macroclinium villenarum D.E.Benn. Holotype at MOL (Bennett 4978 in spirit). Photo: D. Trujillo.

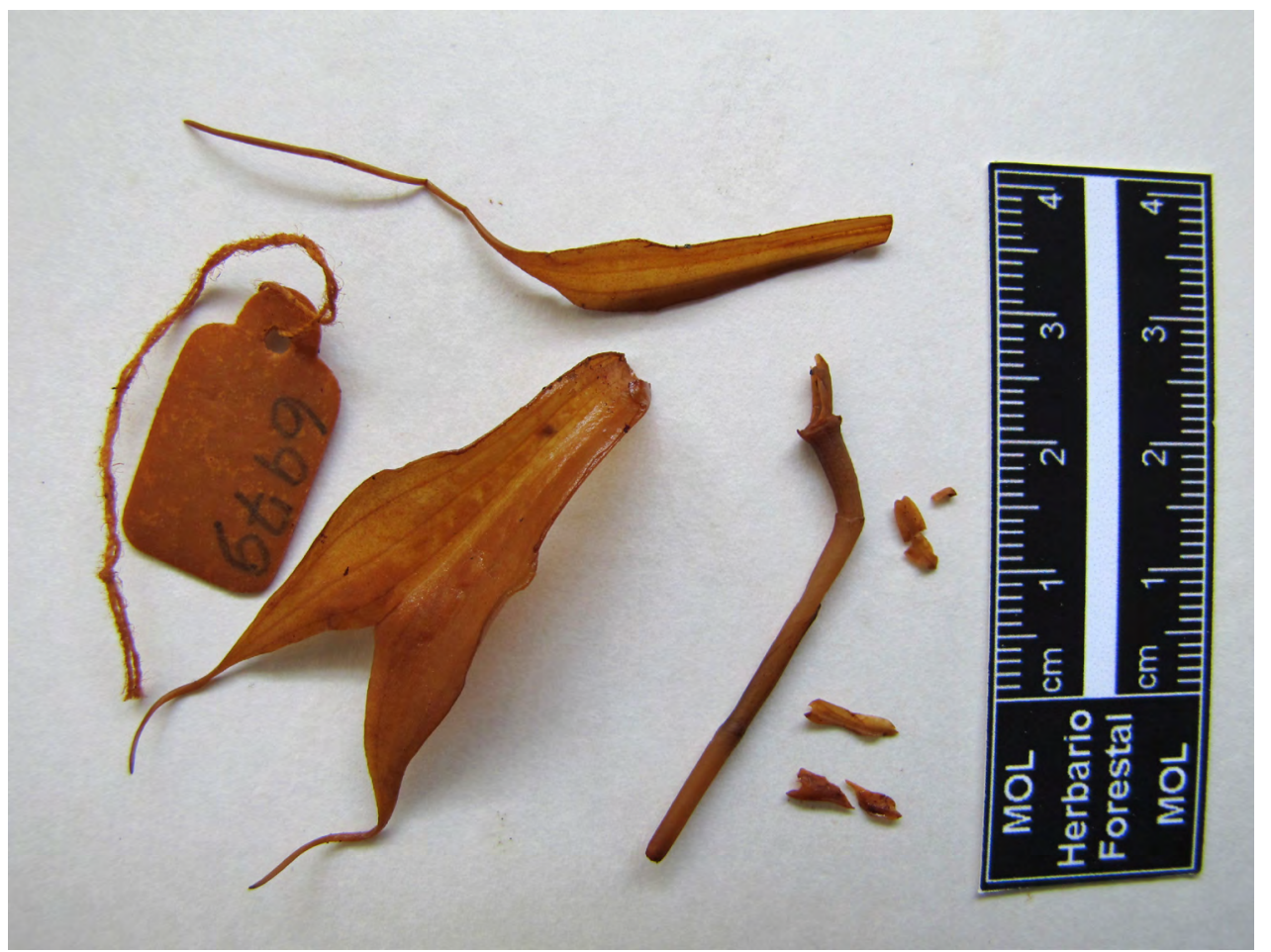

Figure 30. Masdevallia oxapampaensis D.E. Benn. \& Christenson. Holotype at MOL (Bennett 6979 in spirit). Photo: D. Trujillo. 


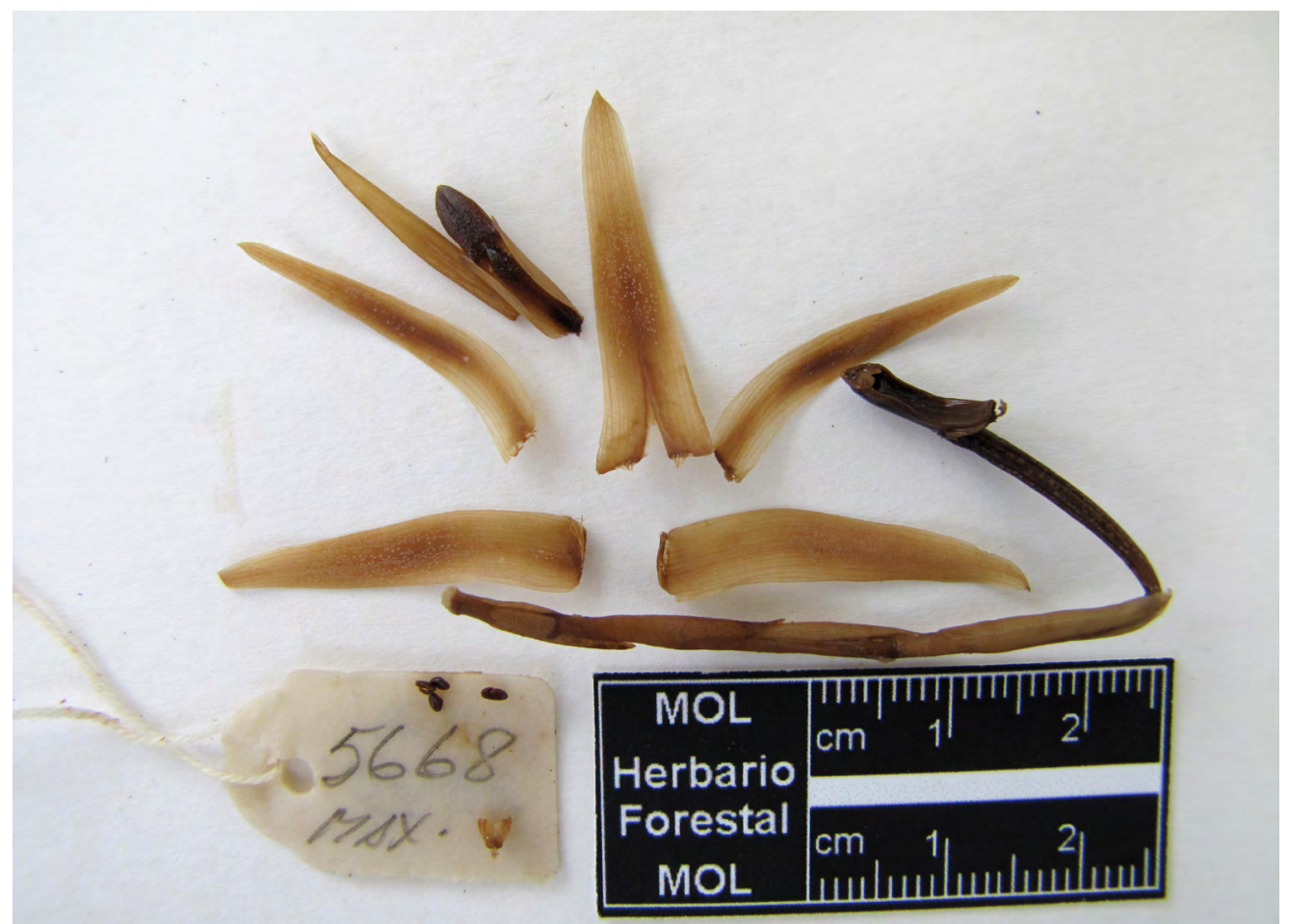

Figure 31. Maxillaria aurorae D.E.Benn. \& Christenson. Lectotype at MOL (Bennett 5668 in spirit). Photo: D. Trujillo.

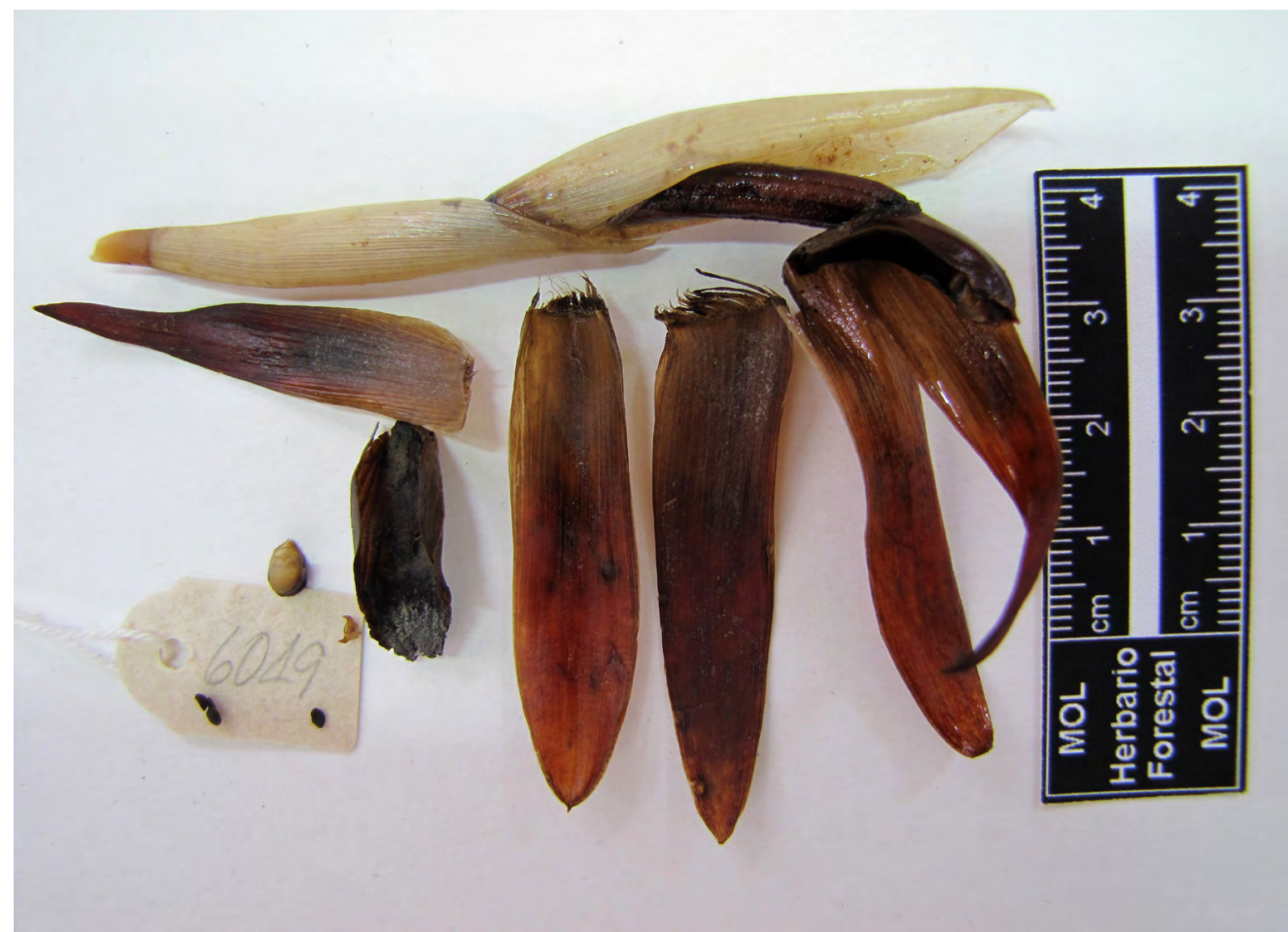

FiguRE 32. Maxillaria burtonii D.E.Benn. \& Christenson. Holotype at MOL (Bennett 6049 in spirit). Photo: D. Trujillo. LANKESTERIANA 14(1), April 2014. (C) Universidad de Costa Rica, 2014. 


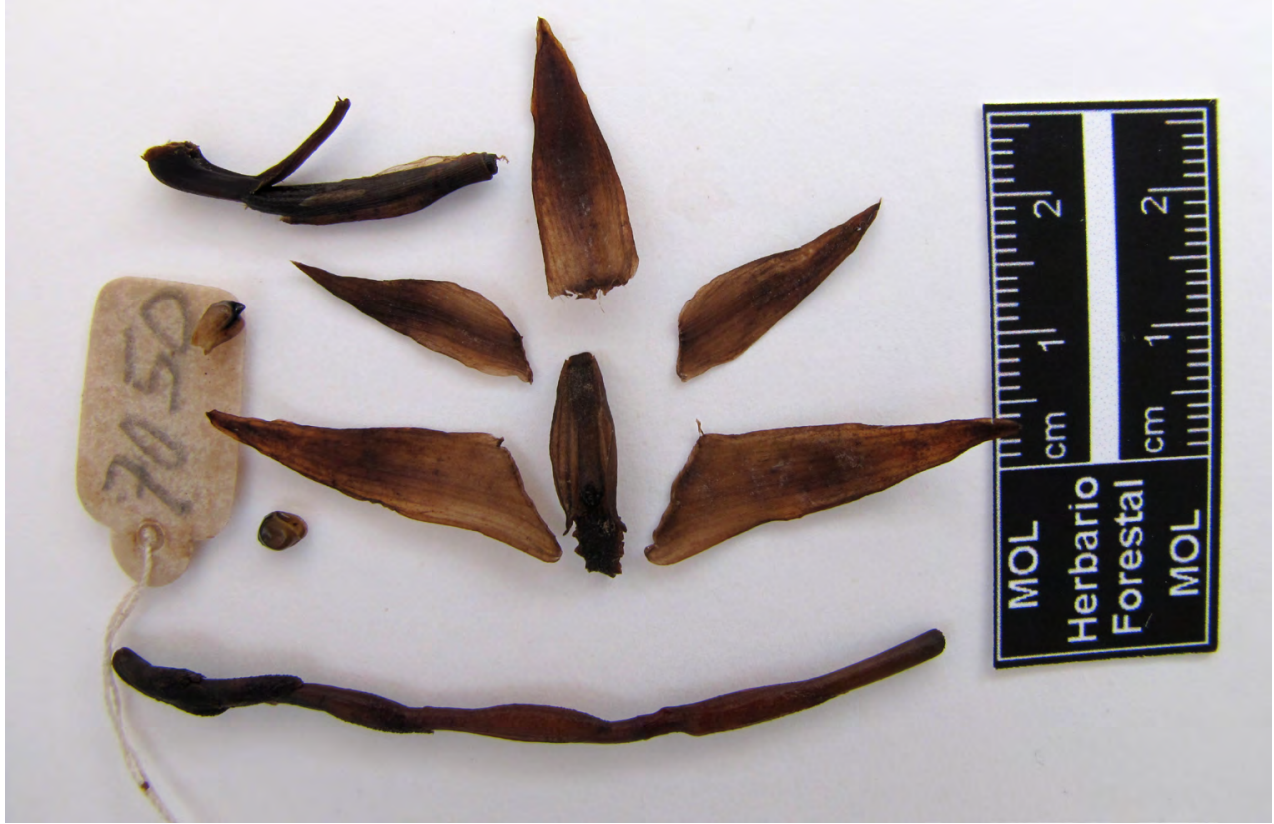

Figure 33. Maxillaria edwardsii D.E.Benn. \& Christenson. Holotype at MOL (Bennett 7050 in spirit). Photo: D. Trujillo.

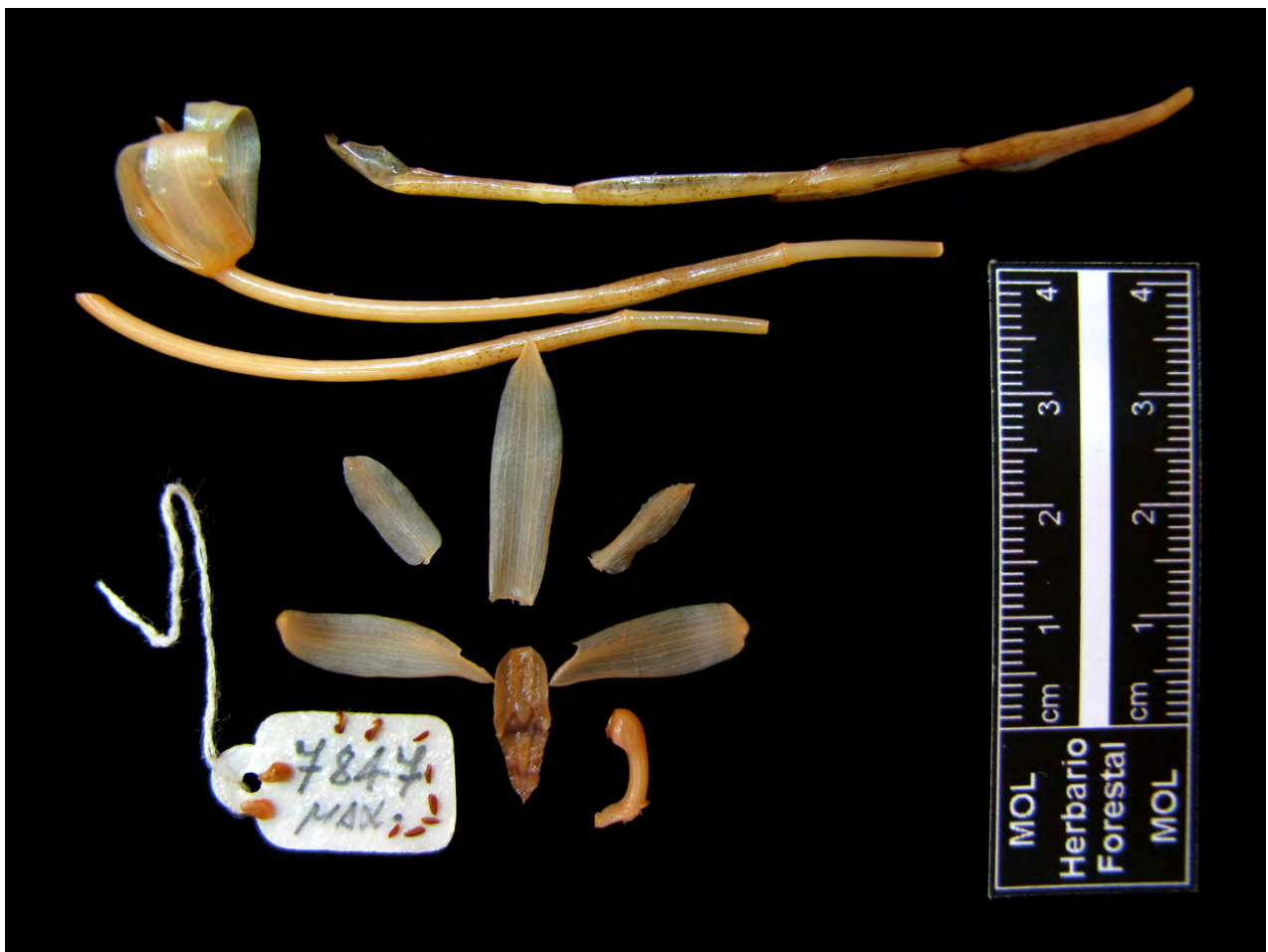

Figure 34. Maxillaria foetida D.E.Benn. \& Christenson. Holotype at MOL (Bennett 7847 in spirit). Photo: D. Trujillo. 


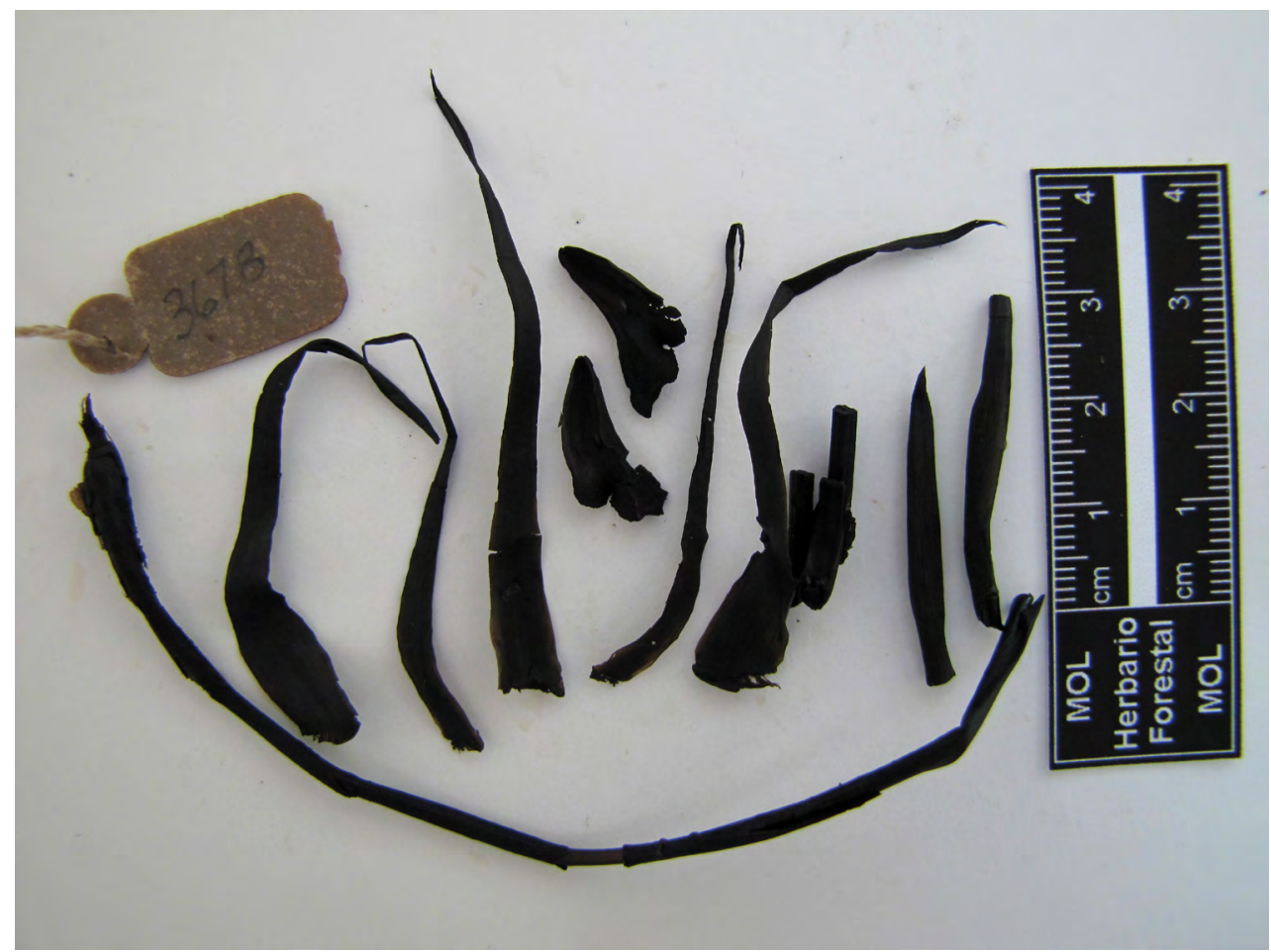

Figure 35. Maxillaria frechettei D.E.Benn. \& Christenson. Lectotype at MOL (Bennett 3678 in spirit). Photo: D. Trujillo.

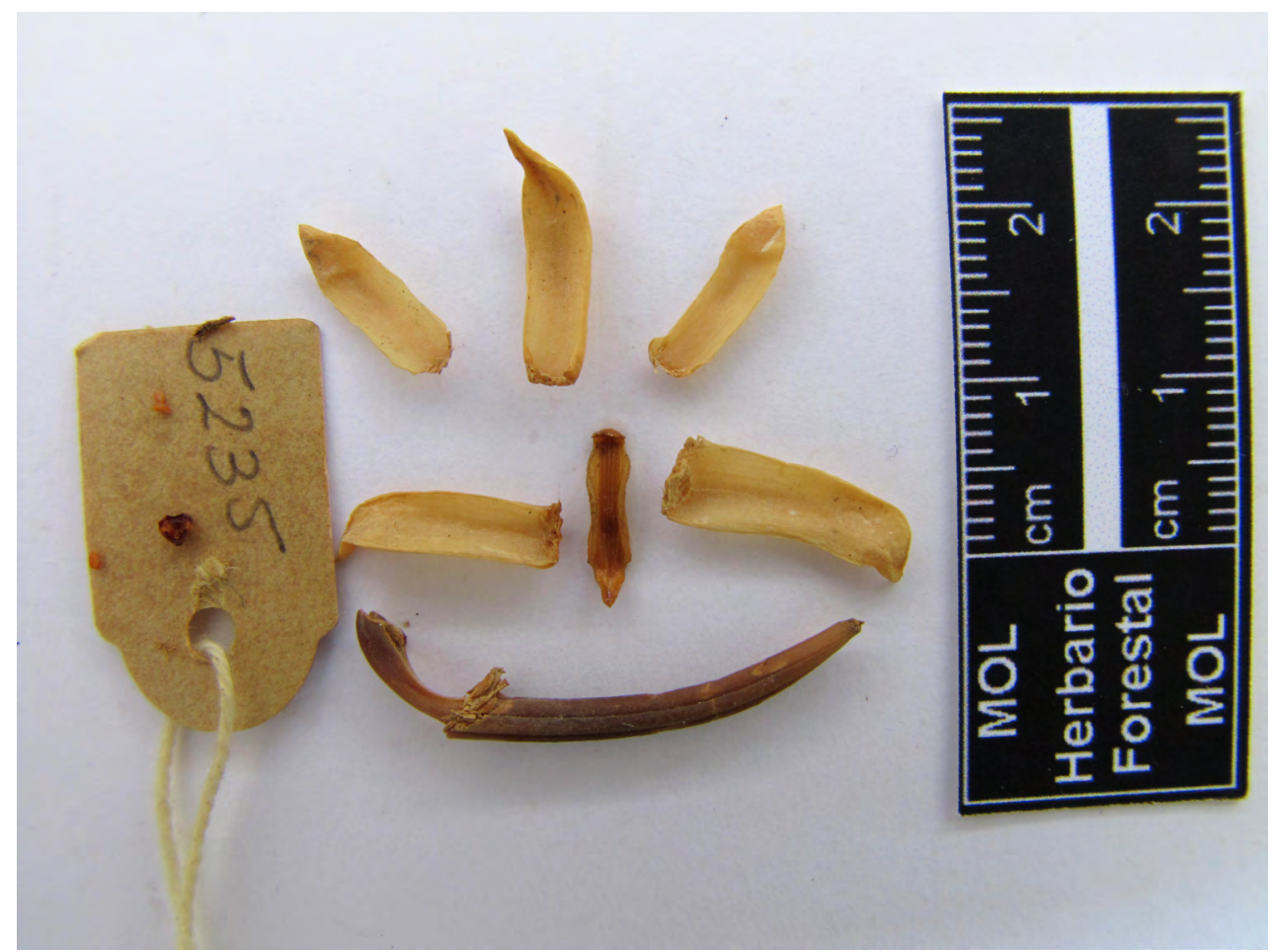

Figure 36. Maxillaria garayi D.E.Benn. \& Christenson. Holotype at MOL (Bennett 5235 in spirit). Photo: D. Trujillo. LANKESTERIANA 14(1), April 2014. (C) Universidad de Costa Rica, 2014. 
data [probably same as in the protologue] Bennett 3678 (MOL-spirit; Fig. 35).

The protologue indicates that the holotype is Bennett et al. 3876; however the illustration voucher is given as Bennett 3678. Two specimens of Bennett 3678 are in the Bennett collection at MOL: one in spirit and one pressed; both agree with the description of the species. Therefore the original type citation in the protologue is erroneous and is corrected here.

The specimen in spirit consists of a dissected flower that agrees with the illustration of the original publication. The herbarium specimen consists of a whole plant (with flowers) but does not have collection data on the label. There is no annotation that indicates that both preparations represent a single sample; nor which one is the holotype. Therefore, as there is no a clear holotype, a lectotype is designated here from among the specimens that comprise the original material (ICN. Art. 9.12); the specimen chosen is the specimen in spirit that was probably used for the species illustration (ICN. 9A.2).

Maxillaria garayi D.E.Benn. \& Christenson, Brittonia 47: 192. 1995.

TYPE: Peru, Pasco: Puerto Bermudez, 250 m, 21 Aug 1992, O. del Castillo ex Bennett 5235. Holotype: according to the protologue at USM, now deposited at MOL[-spirit] (Fig. 36).

Bennett 5235 in spirit was found in the Bennett collection at MOL; however, a pressed preparation was not located in any Peruvian herbarium. The spirit specimen, a dissected flower that agrees with the illustration of the original publication, represents the holotype.

Maxillaria geckophora D.E.Benn. \& Christenson, Icon. Orchid. Peruv.: t. 695. 2001.

TYPE: Peru, Junin, Chanchamayo, Sector Eneñas, $1350 \mathrm{~m}$ along the Pichis trail, O. del Castillo ex Bennett 6475. Holotype: Herb. Bennettianum [now at MOL], lost [see below]. LectotyPE here designated: Peru, without locality data [probably same as in the protologue] Bennett 6475 (MOL-spirit; Fig. 37).

The original material found in the Bennett collection at MOL consists of two specimens of Bennett 6475: one in spirit and one pressed. The specimen in spirit is a dissected flower that agrees with the illustration of the original publication. The illustration was prepared on July 27, 1994; probably on this date the specimen in spirit was prepared. The herbarium specimen was prepared on July 28, 1994. However neither of them has an annotation that indicates it is the holotype. Therefore, a lectotype is designated here from among the specimens that comprise the original material (ICN. Art. 9.12); the specimen chosen is the specimen in spirit that was probably used for the species illustration (ICN. 9A.2).

Maxillaria gigantea subsp. condorensis D.E.Benn. \& Christenson, Lindleyana 13: 68. 1998.

TYPE: Peru, Amazonas, Condorcanqui, Cordillera del Condor, Meseta de Machinaza, 2200 m, Aug 1994, M. Cavero B. et al. 1649. Holotype: according to the protologue at USM, now deposited at MOL, [SYNTYPES, see below]. Lectotype here designated: without collection data [probably same as in the protologue], M. Cavero B. et al. 1649 ( MOL; Isolectotype: MOL [x2], MOL-spirit).

Type specimens were deposited at MOL by Bennett seven years later (in 2001) and were never at USM.

Four specimens of M. Cavero 1649 were found in the Bennett collection at MOL: one in spirit and three pressed. The pressed specimens were in separate folders, un-mounted and lacking labels; but with collection number. None of the specimens has an annotation that indicates that it is the holotype (or isotype). Therefore the four specimens found in the Bennett collection represent syntypes (ICN. Art. 40 Note 1). As there is not a clear holotype, the lectotype is designated here (ICN. Art. 9.2). The specimen here chosen as lectotype is the most complete pressed specimen.

Maxillaria granditenuis D.E.Benn. \& Christenson, Lindleyana 13: 71. 1998.

TYPE: Peru, Pasco, Oxapampa, Dist. of Villarica, Canal de Piedra, 1830 m, leg. O. del Castillo, 24 Aug 1994, Bennett 6750. Holotype: NY, lost. LectotyPE here designated: Peru, Pasco, Oxapampa, Dist. of Villarica, Canal de Piedra, 1830 m, 3 Sept 1994, O. del Castillo in Bennett 6750 (MOL, part in spirit). 
The holotype was not found at NY (T. Zanoni, pers. comm.). The extant original material in the Bennett Collection at MOL is here designated as lectotype (ICN. Art. 9.12). However its date of preparation disagrees with that given in the protologue.

Maxillaria hirsutilabia D.E.Benn. \& Christenson, Brittonia 47: 192. 1995.

TYPE: Peru, Junin, Jauja, District of Monobamba, Sector Cedrulla, 2300 m, 6 Aug 1993, O. del Castillo ex Bennett 6324. Holotype: NY, lost; Isotype: USM, lost. Leстотуре here designated: Peru, Junin, Jauja, above of Monobamba, Cedrulla, 2300 m, 8 Sep 1993, O. del Castillo ex Bennett 6324 (MOL; Isolectotype: MOL-in spirit).

No type specimen was found at NY (T. Zanoni, pers. comm.) neither at USM. The original material found in the Bennett collection at MOL consists of two preparations of Bennett 6324: one pressed and one in spirit. The pressed preparation consists of two plants (with flowers) mounted on a single sheet. This preparation and the illustration were prepared on September 8,1993; which disagrees with the date given in the protologue. The preparation in spirit (a dissected flower) agrees with the illustration of the original publication; therefore this specimen was also prepared on the same date as the pressed one. However, as there is no annotation that indicates that they represent a single specimen, they are treated as duplicates (ICN. Art. 8.3).

In absence of the holotype, a lectotype is designated here from among the specimens that comprise the original material (ICN. Art. 9.12). The specimen chosen here is the most complete (pressed) specimen.

Maxillaria huanucoensis D.E.Benn. \& Christenson, Icon. Orchid. Peruv.: t. 696. 2001.

TYPE: Peru, Huanuco, Quebrada Diez Canseco, 2550 m, 31 Oct 1986, D. Bennett, A. Bennett \& M. Arias 3708. Holotype: originally deposited at Herb. Bennettianum, now at MOL[-spirit] (Fig. 38).

Bennett 3708 in spirit was found in the Bennett collection at MOL; however, as pressed preparation was not located in any Peruvian herbarium. The specimen in spirit, a dissected flower that agrees with the illustration of the original publication, represents the holotype.

Maxillaria leucopurpurea D.E.Benn. \& Christenson, Phytotaxa 1: 31. 2009.

TYPE: Peru, Huanuco, Leoncio Prado, Cueva de Las Pavas, 1000 m, 19 Jan 1988, leg. E. Jara P., D. Bennett 4247. Holotype: MOL, lost [see below]. Lectotype here designated: Peru, Huanuco, Leoncio Prado, above Tingo Maria, 950 m, 28 Jan 1988, E. Jara sn, D. Bennett 4247 (MOL; Isolectotype: MOL-spirit).

The original material found in the Bennett collection at MOL consists of two preparations of Bennett 4247: one pressed and one in spirit. The herbarium specimen consists of a whole plant (with flowers); this preparation and the illustration were prepared on January 28, 1988; which disagrees with the date given in the protologue. The preparation in spirit, consisting of two dissected flowers, agrees with the illustration of the original publication; therefore this specimen was also prepared on the same date as the pressed one. However as there is not annotation that indicates that both preparation represent a single specimen, they are duplicates (ICN. Art. 8.3). Also, none of the specimens has an annotation that indicates it is the holotype.

In absence of the holotype, a lectotype is designated here from among the specimens that comprise the original material (ICN. Art. 9.12). The specimen chosen here is the most complete (pressed) specimen.

Maxillaria liliputana D.E.Benn. \& Christenson, Brittonia 47: 195. 1995.

TYPE: Peru, Pasco, Oxampampa. District of Villarica, Canal de Piedra, 1800 m, 29 Aug 1993, J.

E. Campoverde ex Bennett 6401. Holotype: NY, lost; Isotype: USM, lost. LeCTOTYPE here designated: Peru, without exact locality [probably same as in the protologue], Bennett 6401-1 (MOL-spirit; Fig. 39).

Type specimens were not found at NY (T. Zanoni, pers. comm.) or at USM. Two specimens of Bennett 6401 with different suffix numbers are in the Bennett collection at MOL: Bennett 6401-1 in spirit and a pressed specimen of Bennett 6401-2 prepared on August 31, 1993 (without locality data). The Table 
Records of the illustrated Bennett's specimens indicates that the illustration of Maxillaria liliputana was based on Bennett 6401-1 (LAM-911). However, neither Bennett 6401-1 nor Bennett 6401-2 is cited in the type designation of the protologue.

As not cited specimens exist, the lectotype is chosen from among uncited specimens (ICN. Art. 9.12). The specimen chosen here as lectotype is Bennett 6401-1 in spirit that agrees with the illustration of the original publication (ICN. 9A.2).

Maxillaria machinazensis D.E.Benn. \& Christenson, Lindleyana 13: 71. 1998.

TYPE: Peru, Amazonas, Meseta de Cerro Machinaz, 2100 m, August 1994, M. Cavero B. et al. 1642. Holotype: NY!; Isotypes: according to the protologue at USM, now deposited at MOL (x3), MOL-spirit.

Basionym of: Ornithidium machinazense (D.E.Benn. \& Christenson) M.A.Blanco \& Ojeda, Lankesteriana 7: 532. 2007.

The isotypes were deposited at MOL by Bennett on 2001 and were never at USM. The pressed specimens were between newspaper sheets with the collection number written on the sheets.

Maxillaria microiridifolia D.E.Benn. \& Christenson, Icon. Orchid. Peruv.: t. 699. 2001.

TYPE: Peru, Puno, Sandia, Candamo river valley, 550 m, 15 Sept 1998, [flowered in cultivation 3 Sept 1999], M. Cavero B. ex Bennett 7823-2 [Bennett 7823, in error]. Holotype: originally deposited at Herb. Bennettianum, now at MOL, part in spirit; Isotype: NY, lost.

Basionym of: Heterotaxis microiridifolia (D.E.Benn. \& Christenson) Ojeda \& Carnevali, Novon 15: 580. 2005.

In the Bennett's collection at MOL there are two specimens of Bennett 7823 with different suffix numbers and different dates of preparation: Bennett 7823-2 prepared on September 3, 1999 and Bennett 7823-1 on September 21, 1999. Bennett designated those specimens as holotype and isotype respectively (handwritten annotation). However, Bennett 7823-1 is not a duplicate (isotype) of the holotype because they were not made as a single gathering (ICN. Art. 8.2).
Maxillaria minutiflora D.E.Benn. \& Christenson, Icon. Orchid. Peruv.: t. 700. 2001.

TYPE: Peru, Pasco, Oxapampa, 8.5 km below Villarica toward Paucartambo, 1550, 15 Nov 1987 [prepared on 23 Feb 1988], Bennett et al. 4151. Holotype: originally deposited at Herb. Bennettianum, now at MOL, part in spirit.

Basionym of: Ornithidium minutiflorum (D.E.Benn. \& Christenson) M.A.Blanco \& Ojeda, Lankesteriana 7: 533. 2007.

The living specimen was collected on November 15, 1987 and bloomed during January to March (as indicated in the protologue). The herbarium specimen was prepared on February 23, 1988.

Maxillaria purpureolabia D.E.Benn. \& Christenson, Icon. Orchid. Peruv.: t. 702. 2001.

TYPE: Peru, Piura, Ayabaca, between Yanchala and Olleros, 1300 m, 28 Nov 1992, J. Campoverde ex Bennett 5948. Holotype: originally deposited at Herb. Bennettianum, now at MOL[-spirit] (Fig. 40).

Basionym of: Ornithidium purpureolabium (D.E.Benn. \& Christenson) Senghas, Schlechter Orchideen 1/C(44-45): 2776. 2001.

Bennett 5948 in spirit was found in the Bennett collection at MOL; however, a pressed preparation was not located in any Peruvian herbarium. The spirit specimen, consisting of two dissected flowers that agree with the illustration of the original publication is the holotype.

Maxillaria pyhalae D.E.Benn. \& Christenson, Icon. Orchid. Peruv.: t. 703. 2001.

TYPE: Peru, Huancavelica, Tayacaja, Llactapata, 2600 m, 14 Feb 1999, M. León M. et al. 2975. Holotype: originally deposited at Herb. Bennettianum, now at MOL[-spirit] (Fig. 41); Isotype: MOL.

The field work report of M. León et al. indicates that specimens of M. León et al. 2975 were collected on February 14, 1999. The collection consisted of a living plant and pressed and spirit preparations.

The original material of Maxillaria pyhalae located in the Bennett collection at MOL comprises three specimens: two in spirit and one pressed. One of the 
specimens in spirit consists of four intact flowers; and the other is a dissected flower. The pressed specimen and the dissected flower in spirit (that is part of the pressed material) were prepared by Bennett (from the living specimen collected by M. León et al.) on March 5,1999 . Bennett assigned these two preparations his collection number: Bennett 7873.

The specimens prepared by Bennett disagree with the date of preparation given in the protologue, nor was any designated as holotype. But the specimen in spirit, comprising four flowers that was prepared by M. León et al. agrees with the date indicated in the type designation of the protologue, is the holotype.

An additional pressed specimen of M. León et al. 2975 was deposited by the collector at MOL; it is a mounted specimen lacking a label. Although this specimen was not used by Bennett for the species description; it is the pressed specimen prepared by $\mathrm{M}$. León et al. on February 14, 1999. Therefore it is an isotype.

Maxillaria scandens D.E.Benn. \& Christenson, Icon. Orchid. Peruv.: t. 707. 2001.

TYPE: Peru, Cusco, Urubamba, Historic Sanctuary of Machu Picchu, M. León \& B. Collantes 4027. Holotype: CUZ?; Isotype: originally deposited at Herb. Bennettianum, now at MOL.

Basionym of: Ornithidium scandens (D.E.Benn. \& Christenson) M.A.Blanco \& Ojeda, Lankesteriana 7: 5332007.

Bennett assigned the number: "Bennett 7969", to the (isotype) specimen of M. León \& B. Collantes 4027 that he kept in his personal collection.

Maxillaria trigona subsp. amaroensis D.E.Benn. \& Christenson, Icon. Orchid. Peruv.: t. 708. 2001.

TYPE: Peru, Huancavelica, Tayacaja, Amaro, 2400 m, 15 Feb 1999, M. León et al. 2999. Holotype: originally deposited at Herb. Bennettianum, now at MOL[-spirit] (Fig. 42).

Basionym of: Sauvetrea trigona subsp. amaroensis (D.E.Benn. \& Christenson) M.A.Blanco, Lankesteriana 7: 535. 2007.

The field work report of M. León et al. indicates that specimens of M. León et al. 2999 were collected on February 15, 1999. The collection consisted of specimens: in spirit and living plant(s).

The original material of Maxillaria trigona subsp. amaroensis located in the Bennett collection at MOL consists of: two pressed specimens and two specimens in spirit. One specimen in spirit seems to be prepared by Bennett because the label bears his handwriting. The other specimen in spirit has the label of M. León; therefore was prepared by him on the same date cited on the protologue; therefore this is the holotype.

The pressed specimens were prepared by Bennett (from the living specimen collected by M. León et al.) on different dates: March 12, 1999 and April 6, 1999, respectively. He gave to these his number: Bennett 7877 .

Maxillaria trilobulata D.E.Benn. \& Christenson, Brittonia 47: 197. 1995.

TYPE: Peru, Huanuco, Huanuco, along old road below Carpish, 2300 m, 10 Oct 1986, D. Bennett \& A. Bennett 3737. Holotype: according to the protologue at USM, now deposited at MOL[-spirit] (Fig. 43).

Bennett 3737 in spirit was found in the Bennett collection at MOL; however, a pressed preparation was not located in any Peruvian herbarium. The specimen in spirit, a dissected flower that agrees with the illustration of the original publication, represents the holotype.

Maxillaria tuerosii D.E.Benn. \& Christenson, Icon. Orchid. Peruv.: t. 709. 2001.

TYPE: Peru, Huancavelica, Tayacaja, Inquilpata, 2700 m, 16 Feb 1999 [15 Feb 1999, in error] [prepared on 20 Feb 1999], M. León M. et al. 3013 [ex Bennett 7874]. Holotype: originally deposited at Herb. Bennettianum, now at MOL, part in spirit.

The field work report of M. León et al. indicates that they only collected a living specimen of León et al. 3013 on February 16, 1999 (not February 15, 1999 as was cited in the protologue). Based on this living material David Bennett prepared the type specimen on February 20, 1999, and assigned to it his number: Bennett 7874. The specimen, consisting of a pressed preparation with a flower in spirit (the flower in spirit carries a label with the numbers León and Bennett), represents the holotype. 


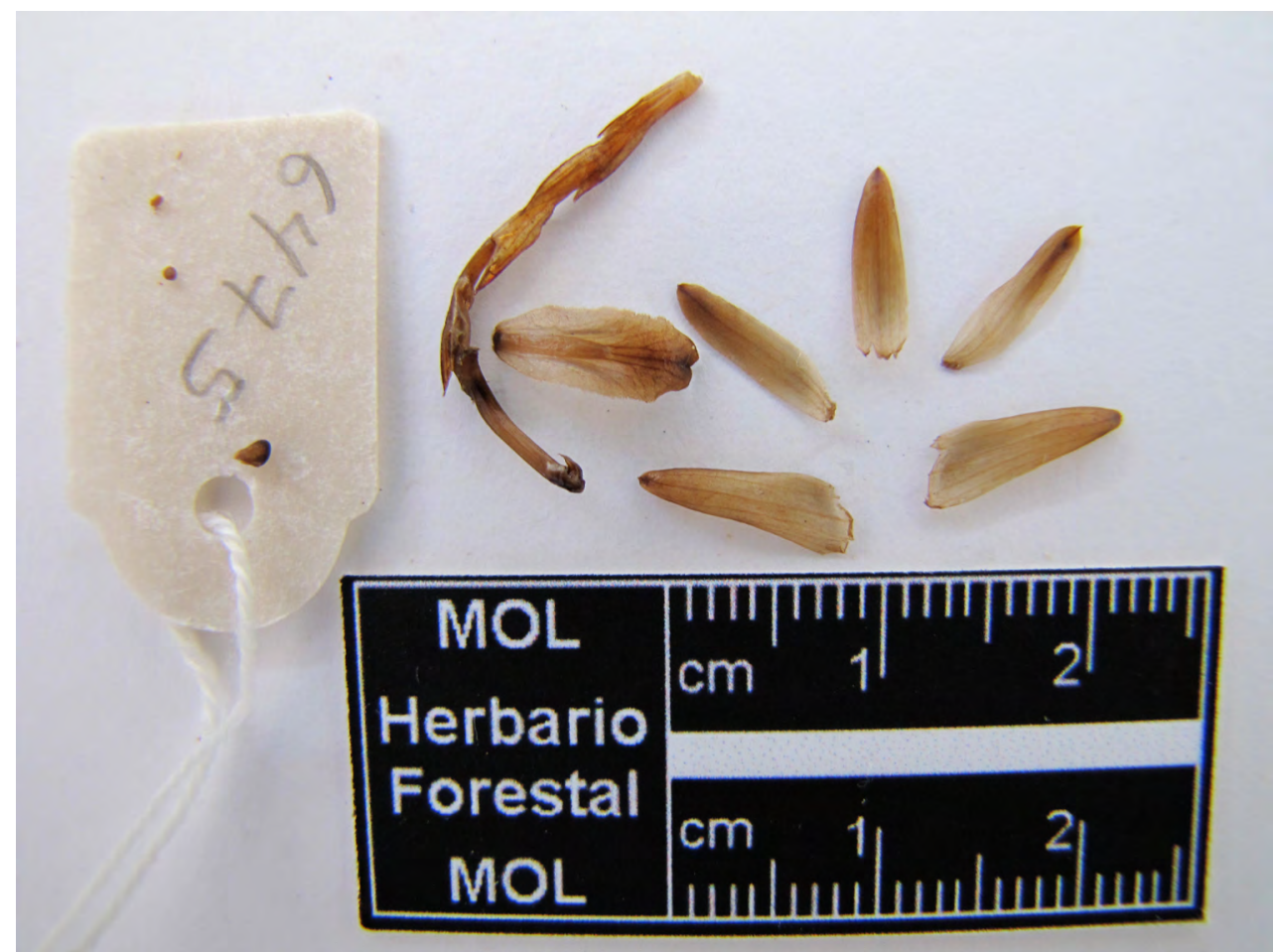

FiguRE 37. Maxillaria geckophora D.E.Benn. \& Christenson. Lectotype at MOL (Bennett 6475 in spirit). Photo: D. Trujillo.

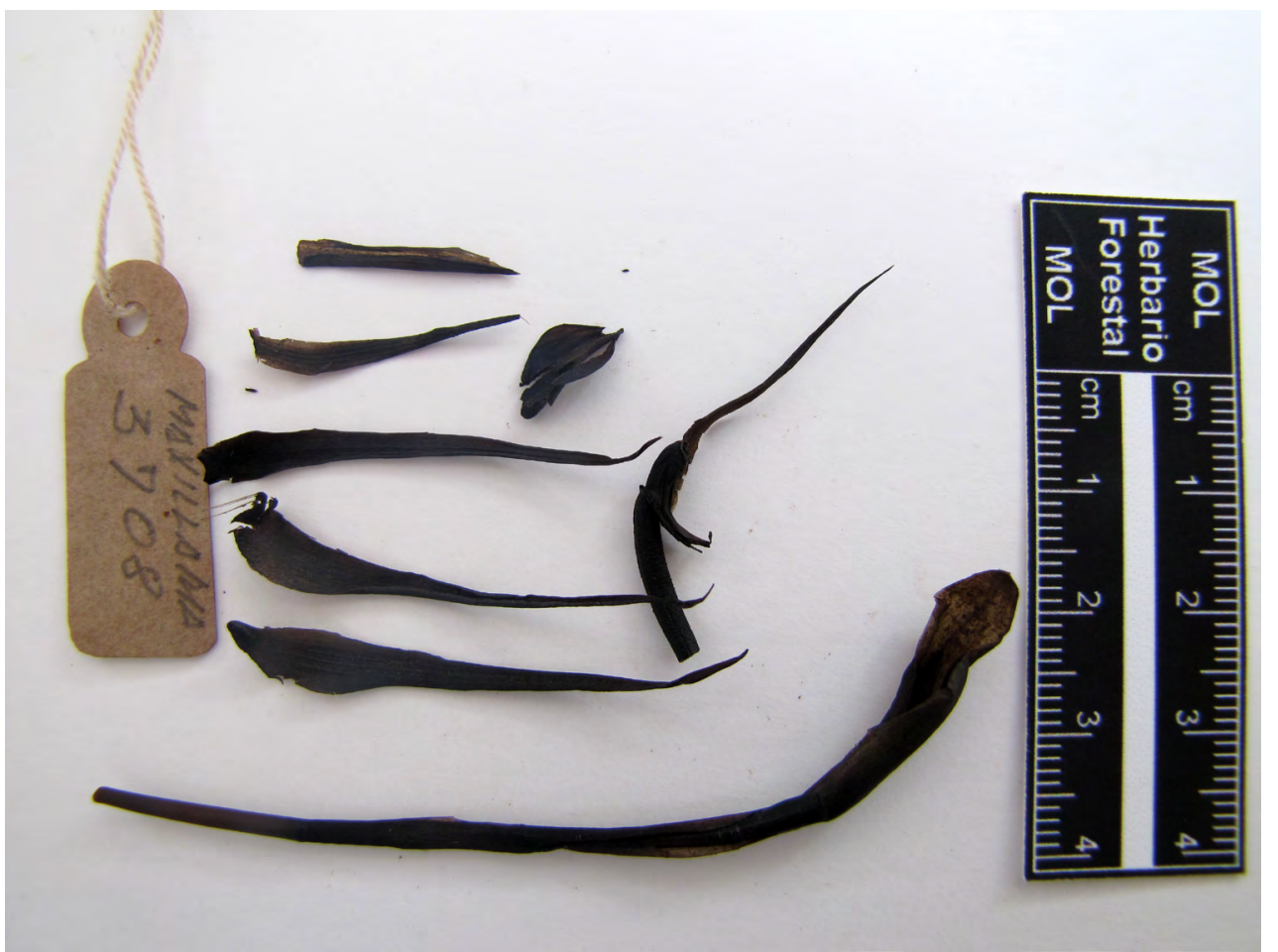

Figure 38. Maxillaria huanucoensis D.E.Benn. \& Christenson. Holotype at MOL (Bennett 3708 in spirit). Photo: D. Trujillo. 


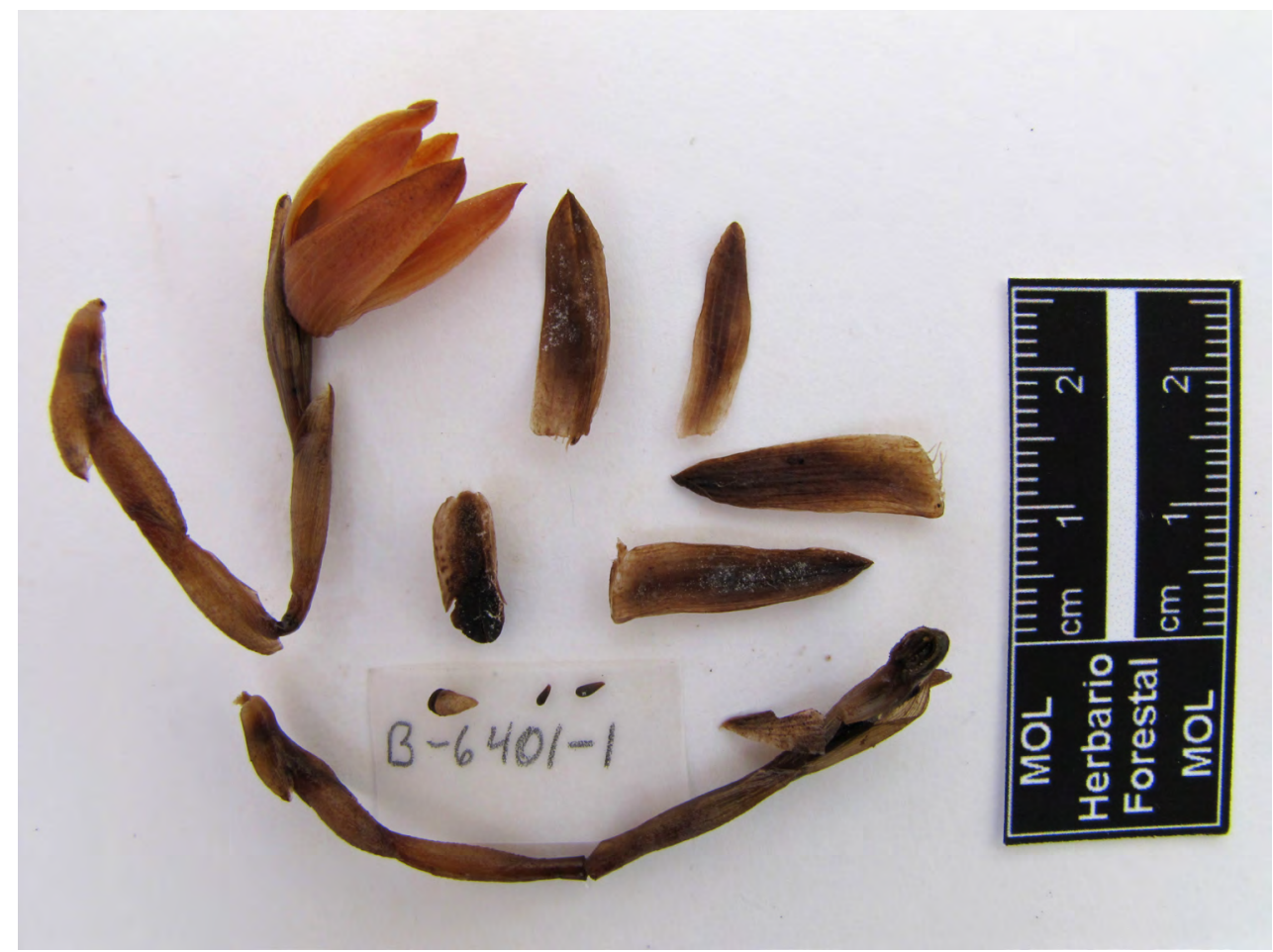

Figure 39. Maxillaria liliputana D.E.Benn. \& Christenson. Lectotype at MOL (Bennett 6401-1 in spirit). Photo: D. Trujillo.

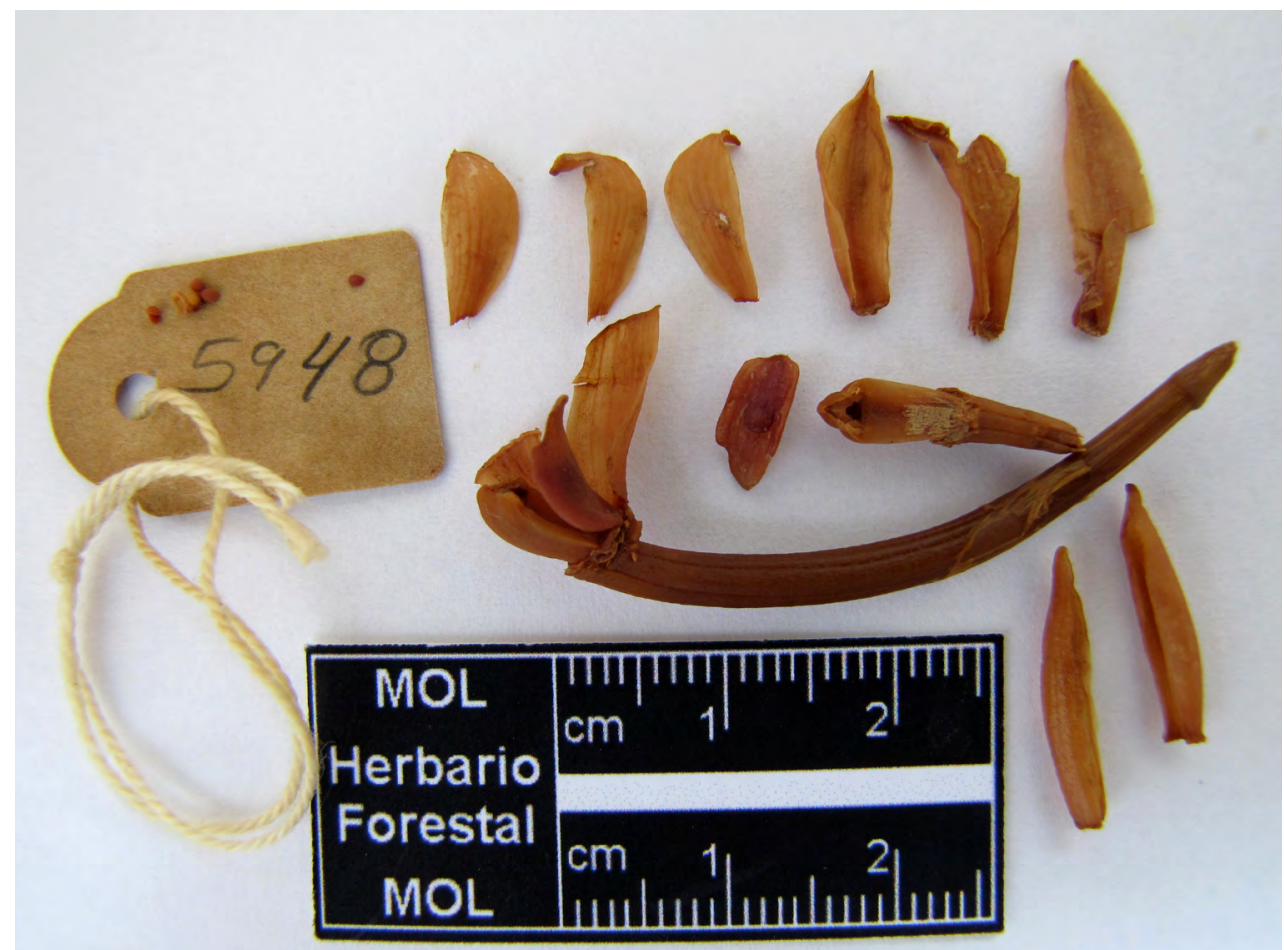

Figure 40. Maxillaria purpureolabia D.E.Benn. \& Christenson. Holotype at MOL (Bennett 5948 in spirit). Photo: D. Trujillo. LANKESTERIANA 14(1), April 2014. (c) Universidad de Costa Rica, 2014. 


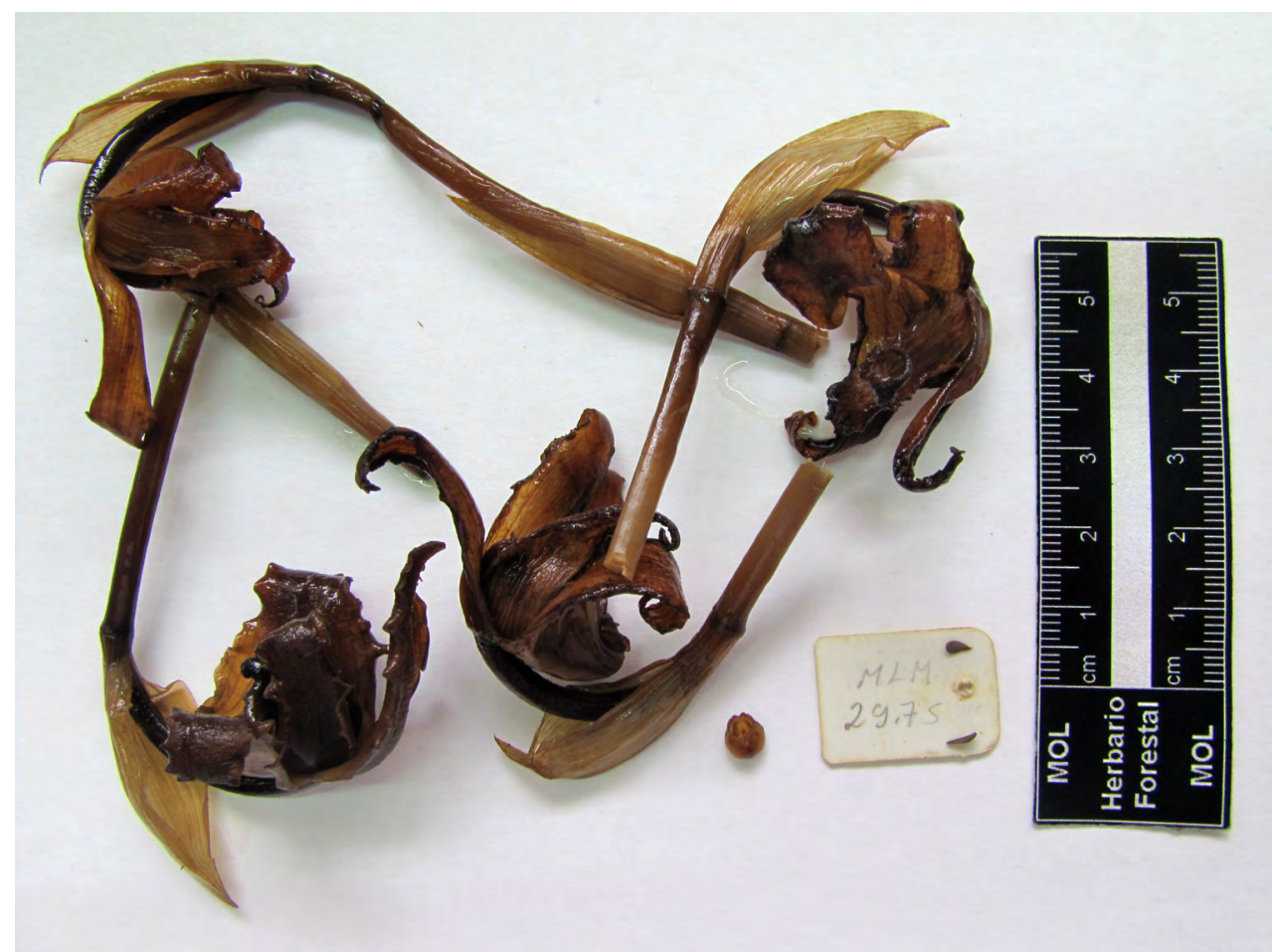

FiguRe 41. Maxillaria pyhalae D.E.Benn. \& Christenson. Holotype at MOL (M. León 2975 in spirit). Photo: D. Trujillo.

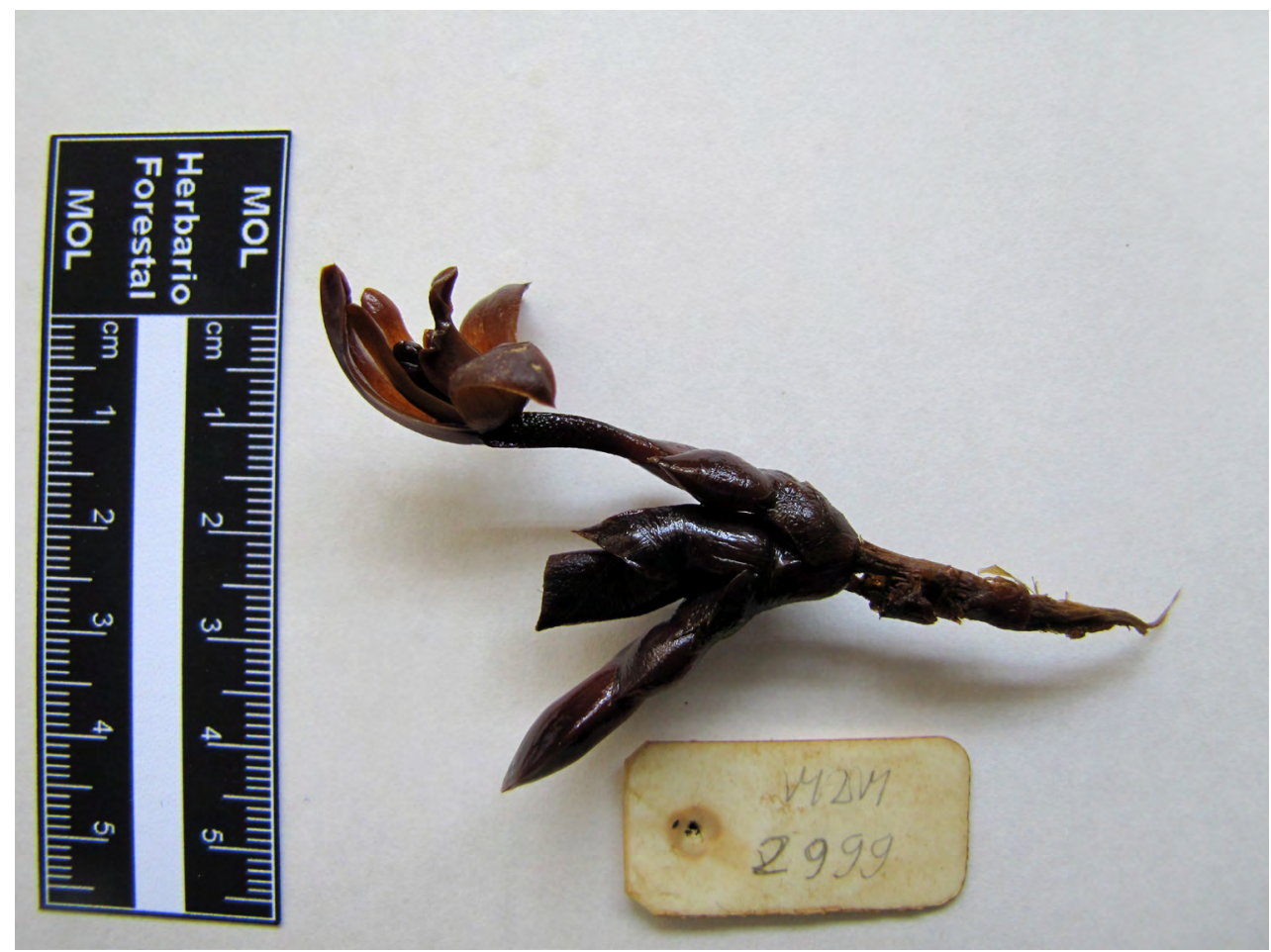

FIguRE 42. Maxillaria trigona subsp. amaroensis D.E.Benn. \& Christenson. Holotype at MOL (M. León 2999 in spirit). Photo: D. Trujillo. 


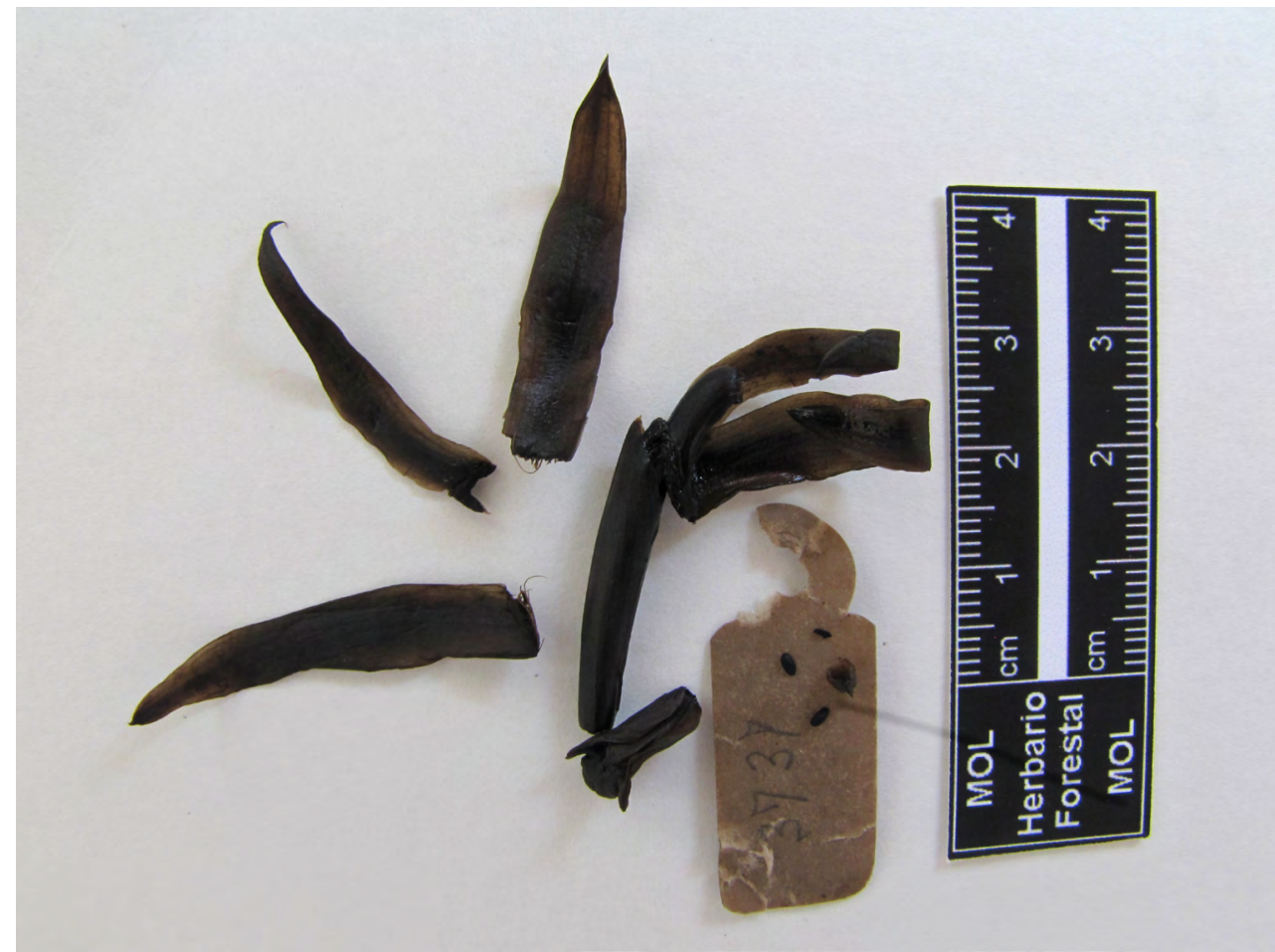

FiguRE 43. Maxillaria trilobulata D.E.Benn. \& Christenson. Holotype at MOL (Bennett 3737 in spirit). Photo: D. Trujillo.

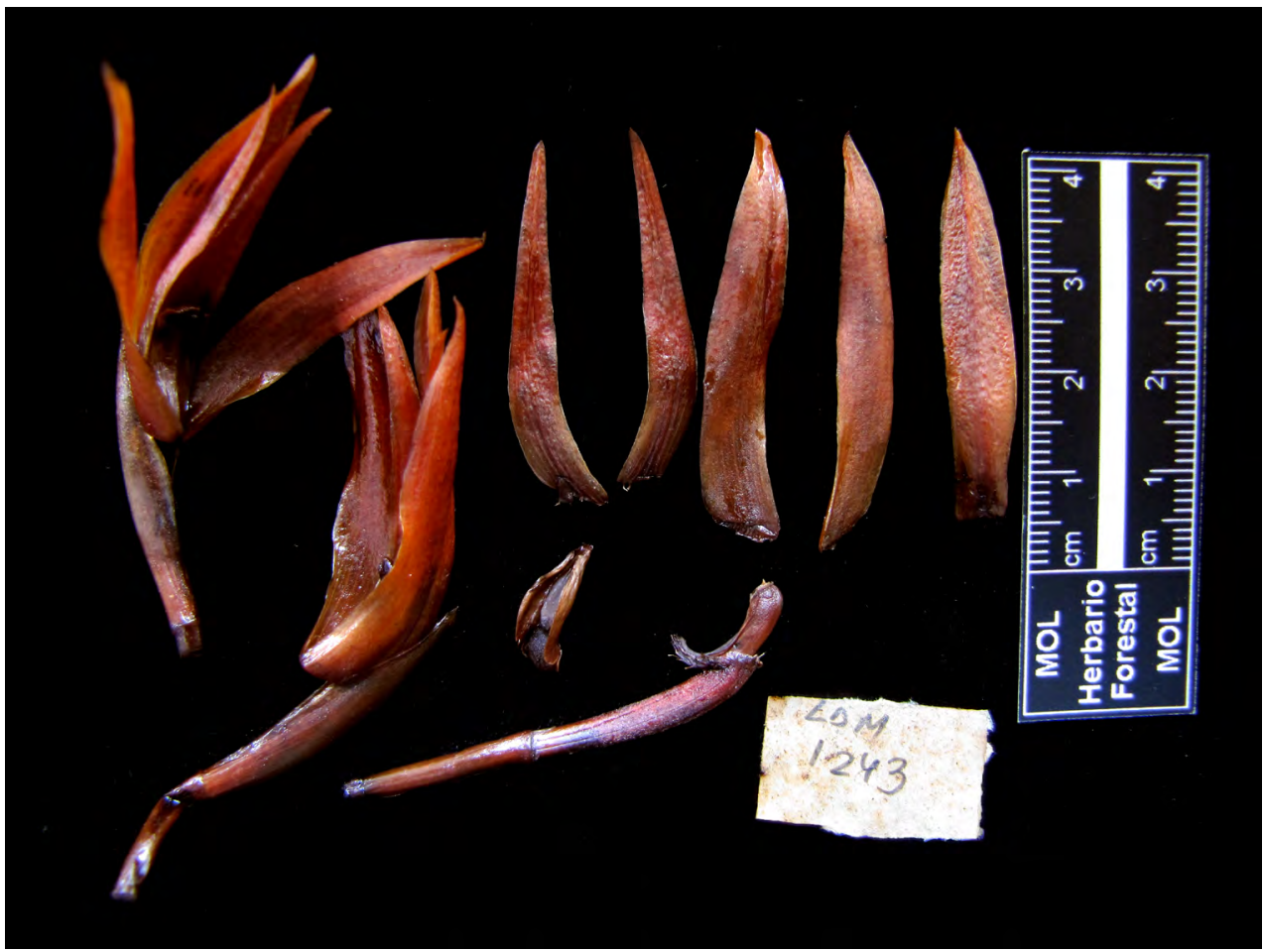

Figure 44. Maxillaria valleculata D.E.Benn. \& Christenson. Lectotype at MOL (Bennett 7423 (LAM 1243) in spirit). Photo: D. Trujillo.. LANKESTERIANA 14(1), April 2014. (C) Universidad de Costa Rica, 2014. 
Maxillaria valleculata D.E.Benn. \& Christenson, Icon. Orchid. Peruv.: t. 711. 2001.

TYPE: Peru, Pasco, Oxapampa, district of Huancabamba, 2010 m, Dec 1995, O. del Castillo ex Bennett 7423. Holotype: Herb. Bennettianum, lost? [see below]. Lестотуре here designated: without locality data [probably same as in the protologue] 12 Dec 1995, Bennett 7423 (LAM 1243) (MOL-spirit; Fig. 44).

When Bennett \& Christenson (2001) published this Maxillaria, they designated as the holotype $O$. del Castillo ex Bennett 7423 prepared on "Dec 1995" and deposited at Herb. Bennettianum. However, in the Herb. Bennettianum -now at MOL- I have found two pressed specimens of $O$. del Castillo ex Bennett 7423 prepared on "Dec 1995" but on different days. One was prepared on December 13, 1995 and the other on December 14, 1995, therefore they represent two different gatherings. Both specimens agree with the species description; however neither is annotated as the holotype.

A specimen in spirit comprising of three flowers (one dissected) labeled as "LAM 1243" was found in the Bennett collection at MOL. The Table Records of the illustrated Bennett's specimens indicates that the plate or Lamina number " 1243 " corresponds to the specimen Bennett 7423 (Maxillaria valleculata). The flowers agree with the illustration of the original publication. The illustration was prepared on December 12,1995 ; probably the specimen in spirit was prepared on that date.

As there is not a clear holotype; the specimen in spirit used for the species illustration is designated here as the Lectotype (ICN. Art. 9.12, 9A.2).

Mesadenella variegata D.E. Benn. \& Christenson, Icon. Orchid. Peruv.: t. 713. 2001.

TYPE: Peru, Piura, Ayabaca, along mule trail above Yanchala to Laguna Prieta, 3000 m, 8 Nov 1992, D.E.Bennett \& J. Campoverde 5838. Holotype originally deposited at Herb. Bennettianum, now at MOL[-spirit] (Fig. 45).

Three specimens of Bennett 5838; that represent different species, were found in the Bennett collection at MOL; one in spirit and two pressed. The specimen in spirit, consisting of a dissected flower that agrees with the illustration of the original description is the holotype of Mesadenella variegata.

The two pressed specimens were prepared on different dates. One was prepared on March 16, 1993 , but has no locality data on the label and has lost the flowers. The remaining part of the specimen that still is preserved more and less agrees with the illustration; but the size of the leaves and the scape disagrees with the description (they are much shorter). It was not possible to identify the specimen; however it belongs to the subtribe Spiranthinae. The other pressed specimen was prepared on November 15, 1992 and is Cyclopogon sp.

Mormolyca aurorae D.E.Benn. \& Christenson, Lindleyana 13: 74. 1998.

TYPE: Peru, Junin, Chanchamayo, Nueva Italia, 1890 m, leg O. del Castillo, 17 Dec 1993, flowered in cultivation Apr 1994, Bennett 6532. Holotype: according to the protologue at USM, now deposited at MOL[-spirit] (Fig. 46).

Bennett 6532 in spirit was found in the Bennett collection at MOL; however, a pressed preparation was not located in any Peruvian herbarium. The specimen in spirit, a dissected flower that agrees with the illustration of the original publication, represents the holotype.

Neodryas acuminata D.E.Benn. \& Christenson, Icon. Orchid. Peruv.: t. 718. 2001.

TYPE: Peru, Huancavelica, Tayacaja, Llactapata, 2500-2600 m, 14 Feb 1999, M. León M. et al. 2966. Holotype: originally deposited at Herb. Bennettianum, now at MOL [Syntypes, see below] Lectotype here designated: Peru, Huancavelica, Tayacaja, Llactapata, 2500-2600 m, 14 Feb 1999, M. León M. et al. 2966 (MOL-spirit (Fig. 47); Isolectotype: MOL, MOLspirit).

The field work report of M. León et al. indicates that specimens of M. León et al. 2966 were collected on February 14, 1999. The collection consisted of living plant(s) and pressed and spirit preparations. The living specimen was wrongly labeled as " $M L M-2967$ " by M. León.

The original material of Neodryas acuminata 
located in the Bennett collection at MOL is comprises one pressed specimen and two specimens in spirit. The pressed specimen was prepared by Bennett from the living specimen collected by M. León et al. on March 3, 1999. He gave it his collection number: Bennett 7872. The date of preparation of this pressed specimen disagrees with the date given in the protologue. One specimen in spirit consists of a whole plant and an inflorescence; and the other specimen in spirit consists of six intact flowers. Both specimens were prepared by M. León (the collection number on the labels bear his handwriting). Therefore the collection or preparation date of the specimen agrees with the date cited in the type designation of the protologue. However, none of the specimens has an annotation that indicates it is the holotype. Therefore both specimens in spirit are syntypes (ICN. Art. 40 Note 1). The specimen here chosen as lectotype is the most complete specimen in spirit.

An additional pressed specimen of M. León 2966 was deposited by the collector to MOL; it was a mounted specimen without a label. Although it was not used by Bennett for the species' description; this is the pressed specimen prepared by M. León et al. on February 14, 1999. Therefore it is a duplicated of the lectotype.

Neodryas llanachagaensis D.E. Benn. \& Christenson, Icon. Orchid. Peruv.: t. 720. 2001.

TYPE: Peru, Pasco, Oxapampa, Yanachaga-Chemillen [Llanachaga-Chemellin, in error] National Cloud Forest Reserve, Rio Alberto Sector, 1800-2100 m, 1 Feb 1995, O. del Castillo ex Bennett 6977. Holotype: originally deposited at Herb. Bennettianum, now at MOL[-spirit] (Fig. 48).

Bennett 6977 in spirit was found in the Bennett collection at MOL; however, a pressed preparation was not located in any Peruvian herbarium. The spirit specimen, comprising of some flowers (three dissected) agrees with the illustration of the original publication and is the holotype.

Neokoehleria delcastilloi D.E.Benn. \& Christenson, Icon. Orchid. Peruv.: t. 519. 1998.

TYPE: Peru, Junin, Chanchamayo, Gran Playa Centro, farm of Sr. Nestor Montes, 2 Aug 1991, O. del Castillo ex Bennett 5162. Holotype: according to the protologue at USM, now deposited at MOL [see below].

Synonym of: Comparettia oliverosii (Königer) M.W.Chase \& N.H.Williams, Orchid Rev. 118 (1291, Suppl.): 61. 2010.

A pressed specimen of Bennett 5162 (determined as Neokoehleria equitans) was found in the Bennett collection at MOL; however the collection data on the label ("Junin, Chanchamayo, near Yurinaki at $1680 \mathrm{~m}$, 9 August 1991, E. Jara s.n. ex Bennett 5162") disagree with that given in the protologue. The collector on the label could be erroneous; because E. Jara only collected orchids in the Departments of Huanuco or Ucayali, but not Junin. Further study is necessary to check identity of the Bennett 5162 found at MOL.

Neokoehleria papillosa D.E.Benn. \& Christenson, Icon. Orchid. Peruv.: t. 520. 1998.

TYPE: Peru, Junin, Chanchamayo, Gran Playa Centro, farm of Sr. Nestor Montes, 1680 m, 2 Aug 1991, O. del Castillo ex Bennett 5163. Holotype: according to the protologue at USM, lost. LECTOTYPE here designated: Peru, without exact locality [probably same as in the protologue], 23 Aug 1991, Bennett 5163 (MOL).

Basionym of: Comparettia papillosa (D.E.Benn. \& Christenson) M.W.Chase \& N.H.Williams, Lindleyana 21: 29. 2008.

The holotype was not found at USM. A pressed specimen of Bennett 5163 prepared on August 23, 1991 was found in the Bennett collection at MOL; however its date of preparation disagrees with that given in the protologue. The specimen consists of an incomplete inflorescence. The label of the specimen provides color features of the flower (which agree with the original description), indicating that it was drawn; but lacks locality data.

In absence of the holotype, the extant specimen found at MOL is here designated as lectotype (ICN. Art. 9.12).

Notylia punoensis D.E. Benn. \& Christenson, Icon. Orchid. Peruv.: t. 722. 2001.

TYPE: Peru, Puno, Sandia, Yanamayo, 1200 m, 22 Nov 1995, M. León \& B. Collantes 674. Holotype: Herb. Bennettianum [now at MOL], lost [see below]. 
Lectotype here designated: Peru, without exact locality [probably same as in the protologue], M. León \& B. Collantes 674 (MOL-spirit; Fig. 49).

Marco León et al. collected a living specimen of M. León \& B. Collantes 674 and gave it to Bennett for cultivation. The specimen flowered in December (as indicated in the protologue) and then two specimens were prepared by Bennett: one in spirit and one pressed. The specimen in spirit consists of five flowers (two dissected) that agree with the illustration of the original publication. The illustration was prepared on December 9, 1996; probably on the date that specimen in spirit was prepared. The pressed specimen was prepared on December 14, 1996; this specimen was also labeled with the number: Bennett 7714 . However it has not an annotation that indicates it is the holotype. Therefore, as there is not a clear holotype, a lectotype is designated here from among the specimens that comprise the original material (ICN. Art. 9.2, 9.12); the specimen chosen is the specimen in spirit that was probably used for the species illustration (ICN. 9A.2).

Odontoglossum contaypacchaense D.E.Benn. \& Christenson, Icon. Orchid. Peruv.: t. 726. 2001.

TYPE: Peru, Junin, Tarma, District Contaypaccha, Quebrada Seca, 1890 m, 22 Apr 1992, O. del Castillo ex Bennett 5557. Holotype: Herb. Bennettianum [now at MOL], lost [see below]. Lectotype here designated: Peru, Junin, Tarma, District Contaypaccha, 1900 m, 21 Dec 1992, O. del Castillo ex Bennett 5557 (MOL).

Basionym of: Oncidium contaypacchaense (D.E.Benn. \& Christenson) M.W.Chase \& N.H.Williams, Lindleyana 21: 24. 2008.

The living plant of $O$. del Castillo ex Bennett 5557 was collected on April 22, 1992 and flowered during November to December (as indicated in the protologue) and then two specimens were prepared: one pressed and one in spirit. The pressed specimen was prepared on December 21, 1992 with a label that indicates that the illustration of the species was prepared on December 20, 1992; but without indicating if the preparation in spirit is part of the same specimen. The specimen in spirit consists of six flowers (two dissected) that agree with the illustration of the original publication; thus this specimen was prepared on December 20, 1992. Neither of the specimens has an annotation that indicates it is the holotype. Therefore, as there is not a clear holotype, a lectotype is designated here from among the specimens that comprise the original material (ICN. Art. 9.2, 9.12); the specimen chosen is the pressed specimen.

Odontoglossum llanachagaense D.E. Benn. \& Christenson, Icon. Orchid. Peruv.: t. 729. 2001.

TYPE: Peru, Pasco, Oxapampa, Sector Rio Alberto, Yanachaga-Chemillen [Llanachaga-Chemellin, in error] 1900-2100 m, 1 Feb 1995, O. del Castillo ex Bennett 6978. Holotype: originally deposited at Herb. Bennettianum, now at MOL[-spirit] (Fig. 50).

Basionym OF: Oncidium llanachagaense (D.E.Benn. \& Christenson) M.W.Chase \& N.H.Williams, Lindleyana 21(3): 25. 2008.

Bennett 6978 in spirit was found in the Bennett collection at MOL; however, a pressed preparation was not located. The specimen in spirit which consists of two flowers (one dissected) that agrees with the illustration of the original publication is the holotype.

Odontoglossum machupicchuense D.E.Benn. \& Christenson, Icon. Orchid. Peruv.: t. 730. 2001.

TYPE: Peru, Cusco, Urubamba, Historic Sanctuary of Machu Picchu, 13 Sep 2000, M. León \& B. Collantes 4034. Holotype: originally deposited at Herb. Bennettianum, now at MOL[-spirit] (Fig. 51).

Basionym of: Oncidium machupicchuense (D.E.Benn. \& Christenson) M.W.Chase \& N.H.Williams, Lindleyana 21: 25. 2008.

M. León \& B. Collantes 4034 in spirit was found in the Bennett collection at MOL; however, a pressed preparation was not located in any Peruvian herbarium. The specimen in spirit, comprising three flowers (one dissected) that agree with the illustration of the original publication is the holotype.

Odontoglossum pseudomelanthes D.E. Benn. \& Christenson, Icon. Orchid. Peruv.: t. 733. 2001.

TYPE: Peru, Amazonas, Condorcanqui, Meseta de Machinaza, $2200 \mathrm{~m}$, M. Cavero B. et al. 1616. Holotype: originally deposited at Herb. Bennettianum, now at MOL [Syntypes, see below]. LectotyPe here designated: Peru, without collection data [but same as 
the cited in the protologue], M. Cavero B. et al. 1616 (MOL; Isolectotype: MOL [x3], MOL-spirit).

Synonym of: Cyrtochilum melanthes (Rchb.f. \& Warsz.) Kraenzl., Notizbl. Bot. Gart. Berlin-Dahlem 7: 98. 1917.

Five specimens of M. Cavero et al. 1616 were found in the Bennett collection at MOL: one in spirit and four pressed. The pressed specimens were in separate folders, un-mounted and without labels; only an annotation with the collection number. None of the specimens has an annotation that indicates that it is the holotype. Therefore the five specimens found in the Bennett collection represent syntypes (ICN. Art. 40 Note 1). In absence of the holotype, a lectotype is designated here (ICN. Art. 9.2). The specimen here chosen as lectotype is the most complete pressed specimen.

Odontoglossum rubrocallosum D.E.Benn. \& Christenson, Icon. Orchid. Peruv.: t. 734. 2001.

TYPE: Peru, Pasco, Oxapampa, exact locality not recorded, [prepared on 27 May 1996], Hort. E. Edwards, J. Campoverde ex Bennett 7524. Holotype: originally deposited at Herb. Bennettianum, now at MOL.

Basionym of: Oncidium rubrocallosum (D.E.Benn. \& Christenson) M.W.Chase \& N.H.Williams, Lindleyana 21: 26. 2008.

The specimen and the illustration of the species were prepared on May 27, 1996.

Oncidium aurorae D.E. Benn. \& Christenson, Lindleyana 13: 76. 1998.

TYPE: Peru, Piura, Ayabaca, leg. V. Vizquerra, Bennett 3547. Holotype: MO?, [Isotype: MOL].

An isotype of Oncidium aurorae was found in the Bennett collection at MOL. The specimen was prepared on November 9, 1985.

Oncidium ayabacanum D.E. Benn. \& Christenson, Lindleyana 13: 78. 1998.

TYPE: Peru, Piura, Ayabaca, along mule trail to Laguna Prieta Negra, 3200 m, 10 nov 1992, flowered in cultivation 3 Nov 1994 [1993, in error], D. Bennett et al. 5910. Holotype: according to the protologue at
USM, now deposited at MOL[-spirit] (Fig. 52).

The protologue cites that the date of preparation of the holotype was on November 3, 1993; however it is erroneous. The correct date is November 3, 1994; which is also the same date when the specimen was illustrated.

Two specimens of Bennett 5910 are in the Bennett collection at MOL: one in spirit and one pressed. The specimen in spirit consists of a dissected flower that agrees with the illustration of the original publication. The date of preparation is not indicated on the label of this specimen; however, this was probably prepared on same date of the illustration. Therefore, the specimen in spirit is the holotype. The pressed specimen consists of a sterile sample prepared on November 4, 1994. This date of preparation does not agree with the date given in the protologue.

Oncidium bennettii Christenson, Brittonia 47: 200. 1995.

TYPE: Peru, Cuzco, Quillabamba, Inca Tambo, ca. 3000 m, 24 Jun 1990, C. Inchaustegui [J. Perez C, in error] ex Bennett 4641. Holotype: NY, lost. LeCTOTYPE here designated: Peru, without locality data [probably same as in the protologue], Bennett 4641 (MOL-spirit; Fig. 53).

The holotype was not found at NY (T. Zanoni, pers. comm.). The original material of Oncidium bennettii found in the Bennett collection at MOL consists of two specimens of Bennett 4641: one pressed and one in spirit. The pressed specimen consists of an incomplete inflorescence prepared on March 25, 1992; this date disagrees with that given in the protologue. The specimen in spirit consists of three flowers (two dissected) that agree with the illustration of the original publication. The illustration was prepared on March 12, 1992; probably the date that the specimen in spirit was prepared. In absence of the holotype, the lectotype is designated here from among the specimens that comprise the original material (ICN. Art. 9.12). The specimen chosen is the specimen in spirit that was probably used for the species illustration (ICN. 9A.2).

The data written on the label of the pressed specimen indicates that Bennett 4641 was originally collected by Carlos Inchaustegui and not by J. Perez C. as was cited in the protologue. Therefore the original type citation in 


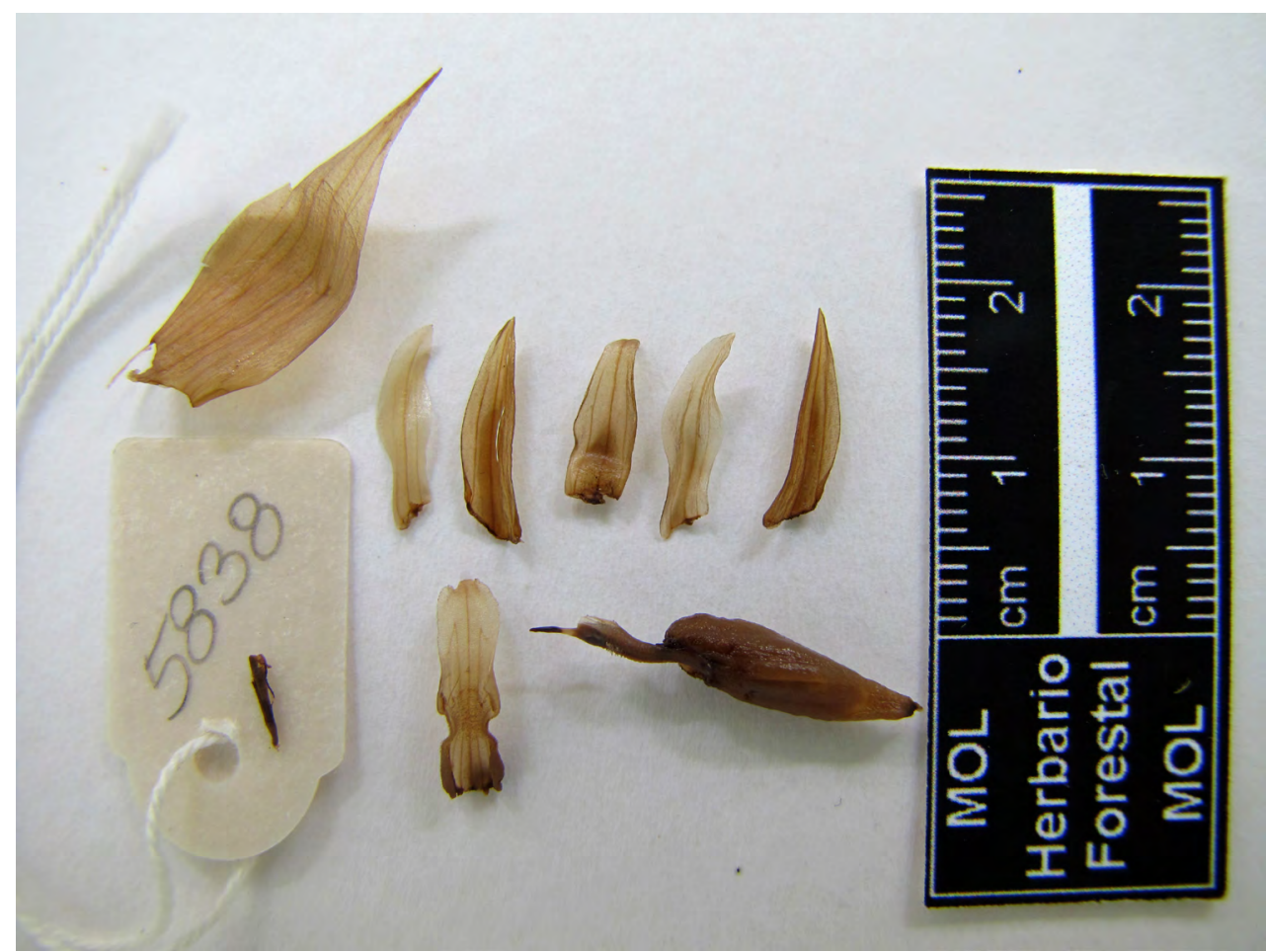

Figure 45. Mesadenella variegata D.E. Benn. \& Christenson. Holotype at MOL (Bennett 5838 in spirit). Photo: D. Trujillo.

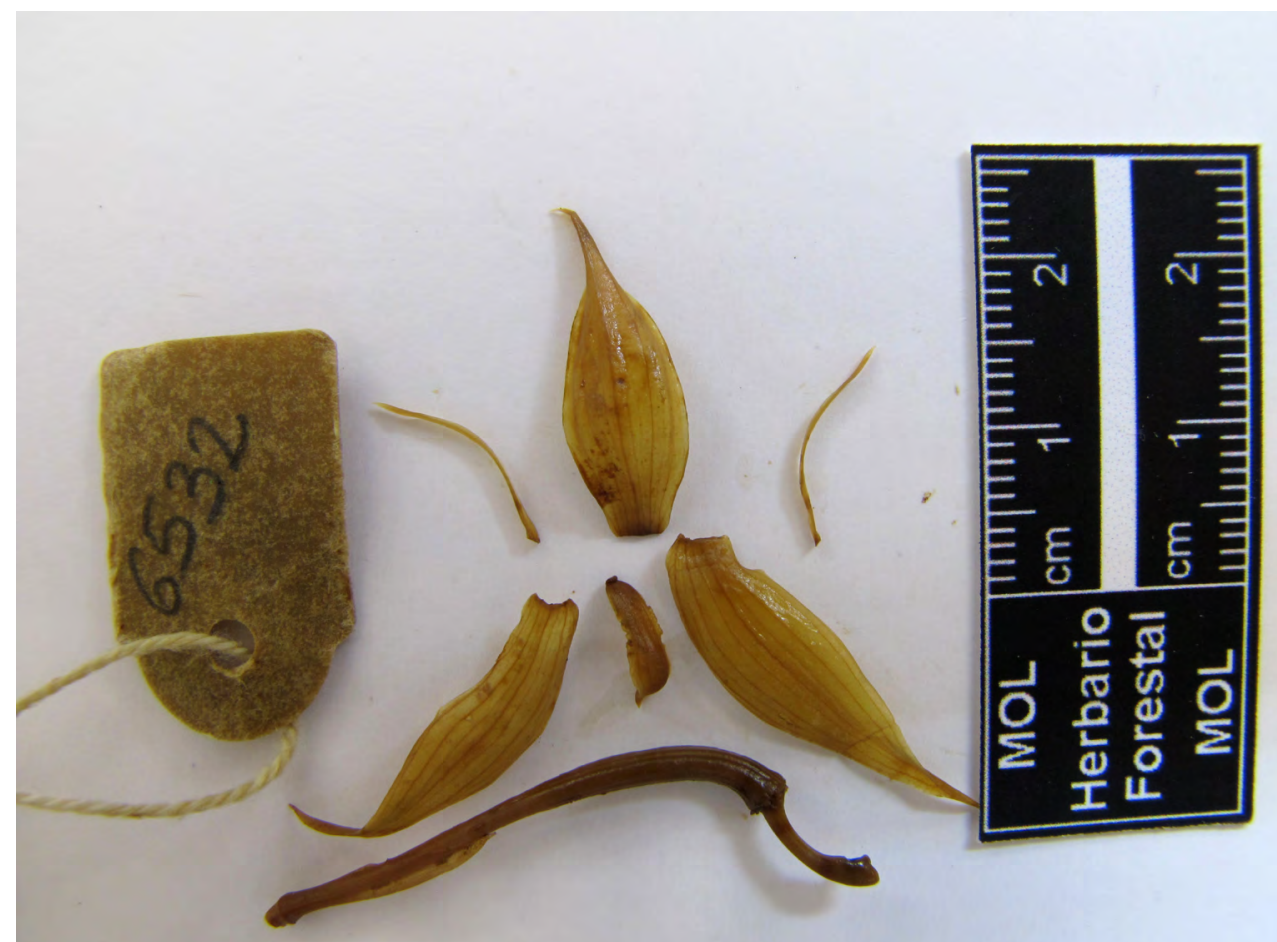

FiguRe 46. Mormolyca aurorae D.E.Benn. \& Christenson. Holotype at MOL (Bennett 6532 in spirit). Photo: D. Trujillo. LANKESTERIANA 14(1), April 2014. (C) Universidad de Costa Rica, 2014. 


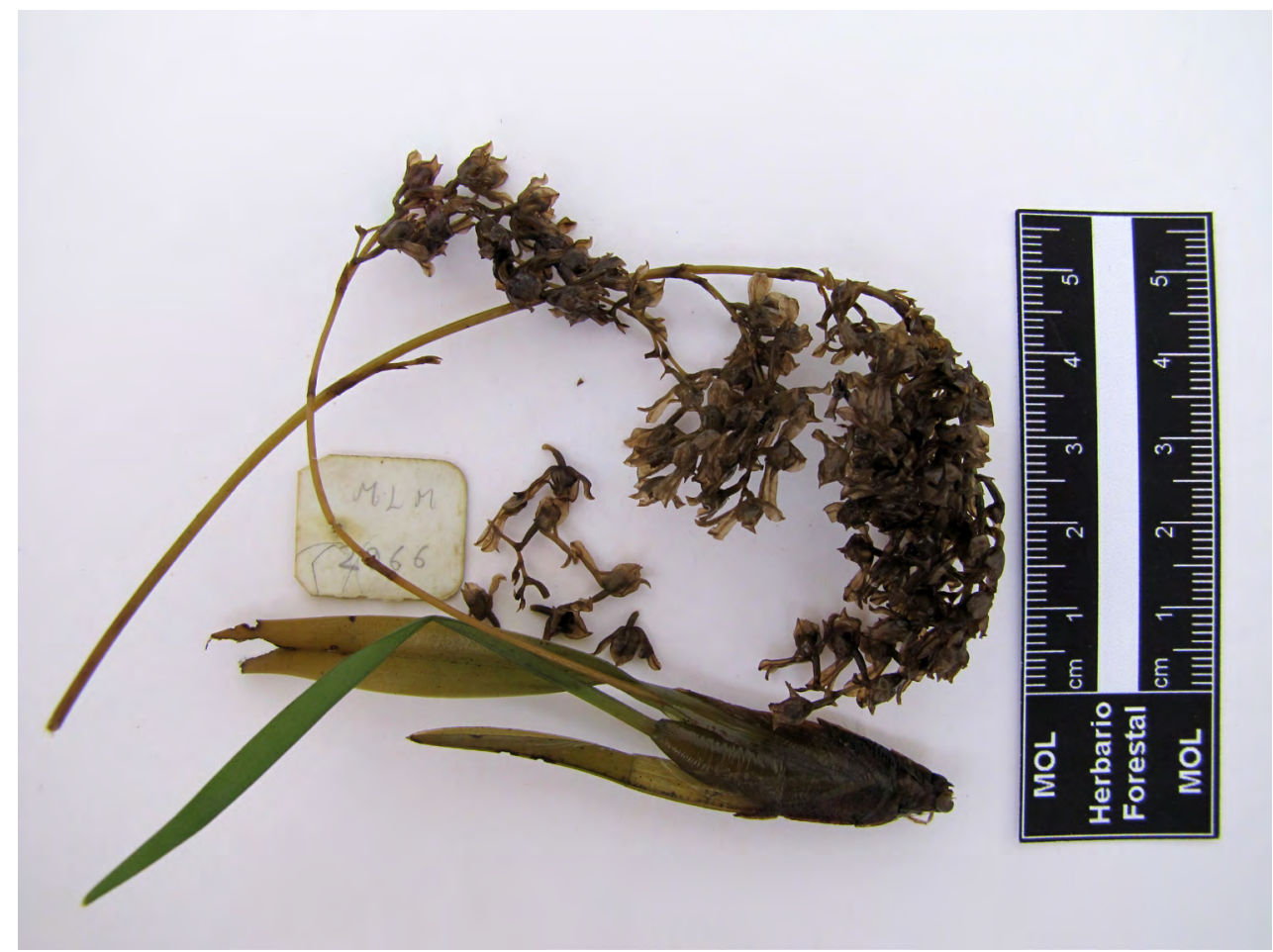

FiguRE 47. Neodryas acuminata D.E.Benn. \& Christenson. Lectotype at MOL (M. León M. 2966 in spirit). Photo: D. Trujillo.

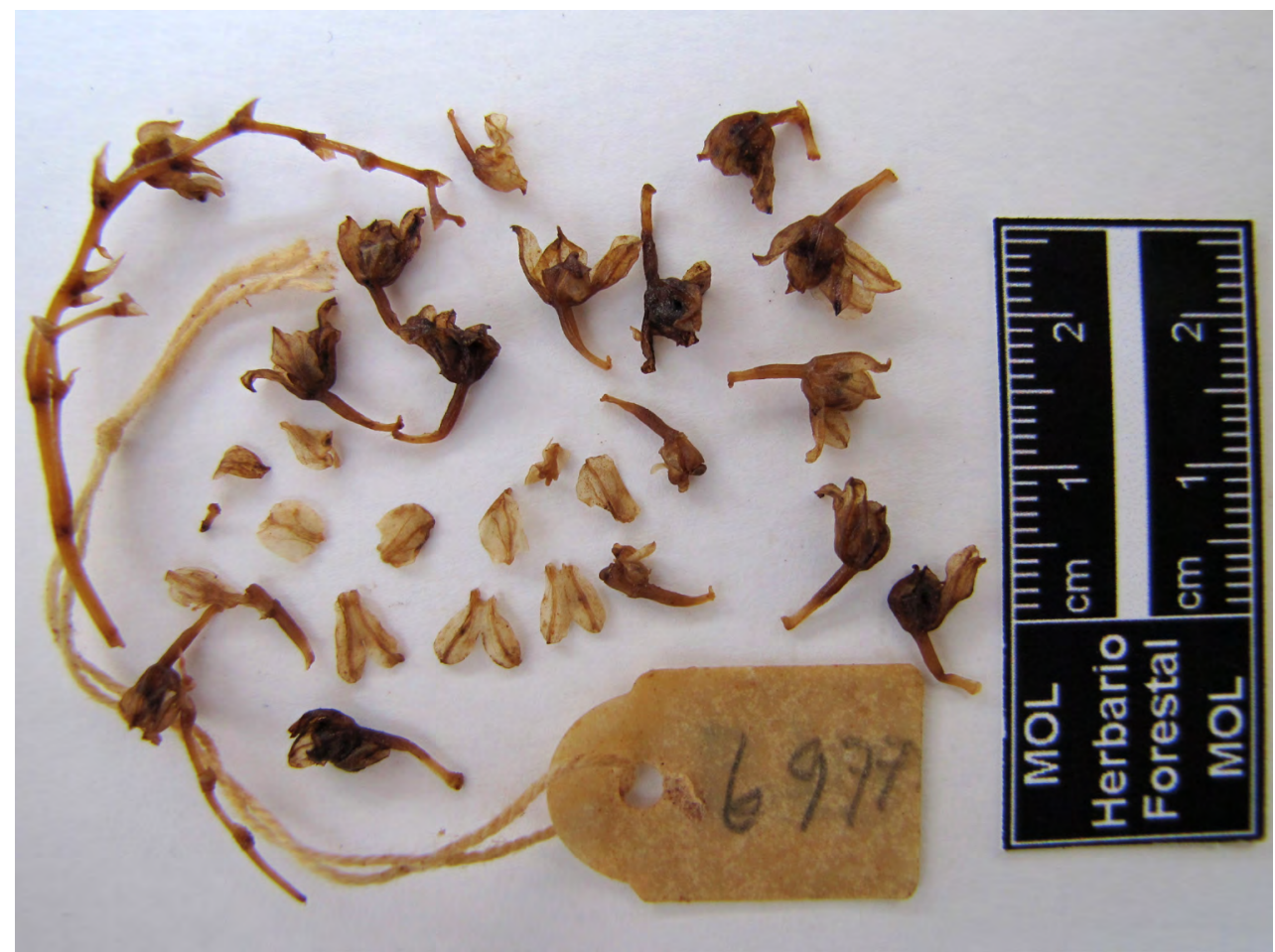

Figure 48. Neodryas llanachagaensis D.E. Benn. \& Christenson. Holotype at MOL (Bennett 6977 in spirit). Photo: D. Trujillo. LANKESTERIANA 14(1), April 2014. (C) Universidad de Costa Rica, 2014. 


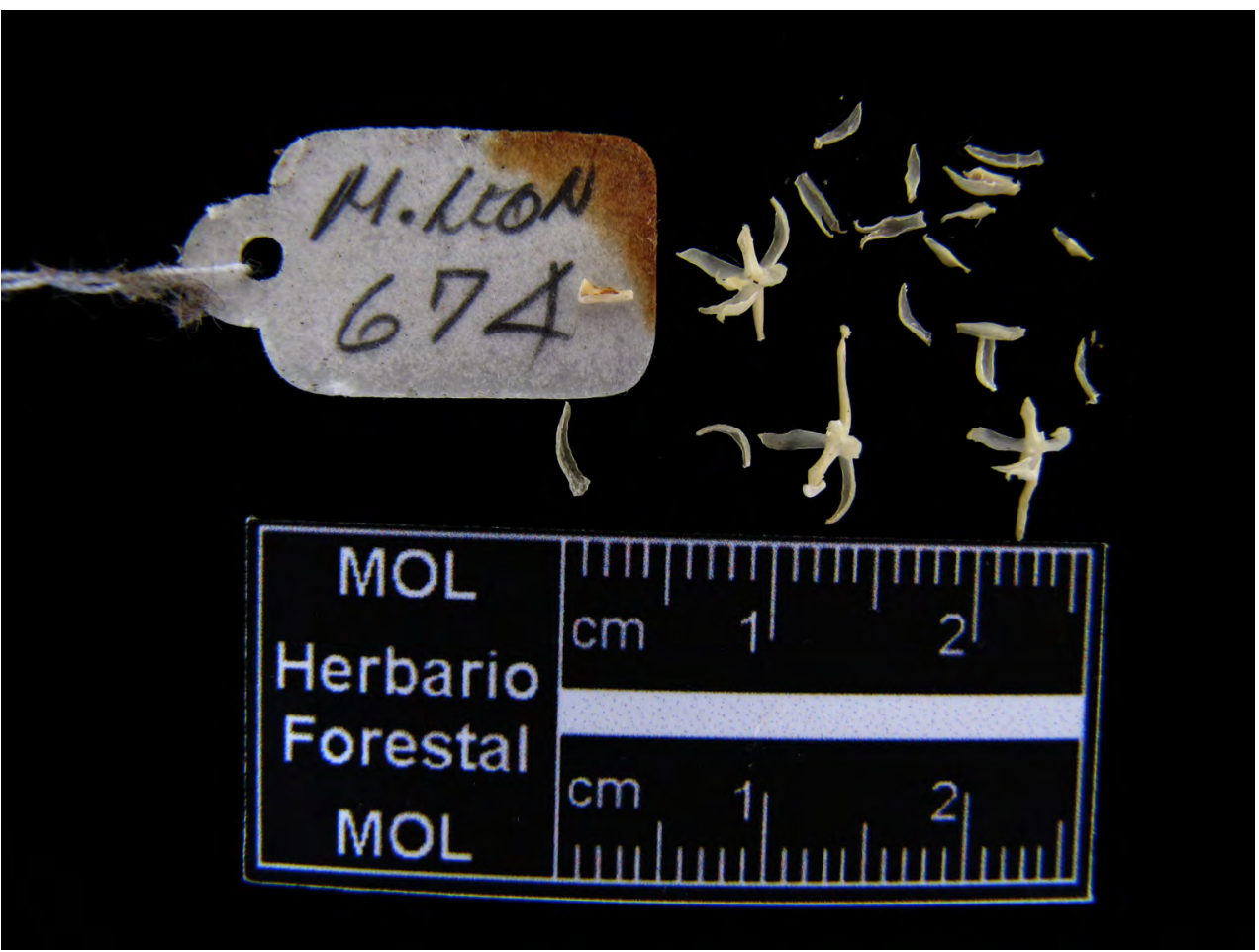

FIGURE 49. Notylia punoensis D.E. Benn. \& Christenson. Lectotype at MOL (M. León 674 in spirit). Photo: D. Trujillo.

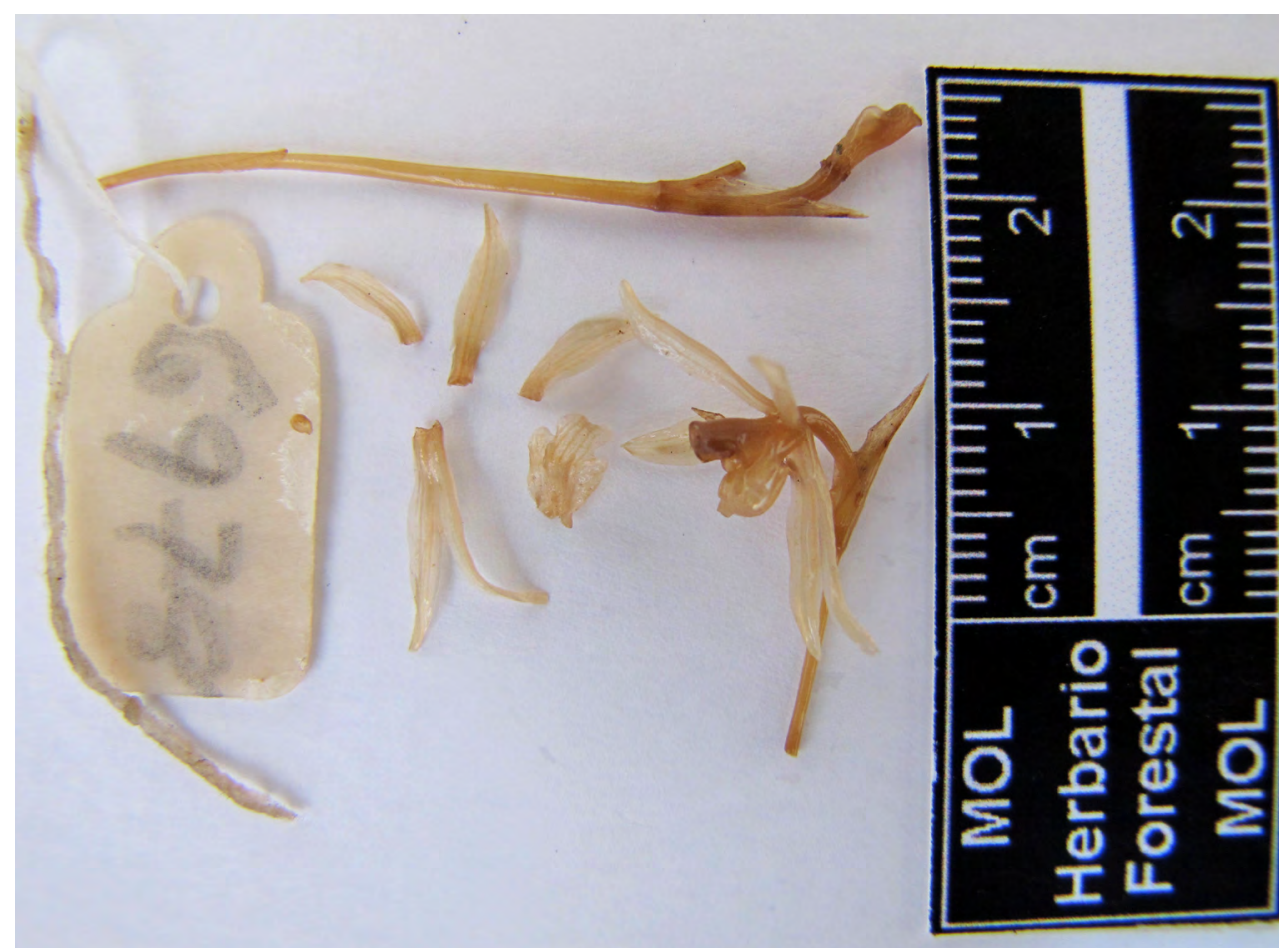

FiguRE 50. Odontoglossum llanachagaense D.E. Benn. \& Christenson. Holotype at MOL (Bennett 6978 in spirit). Photo: D. Trujillo. 


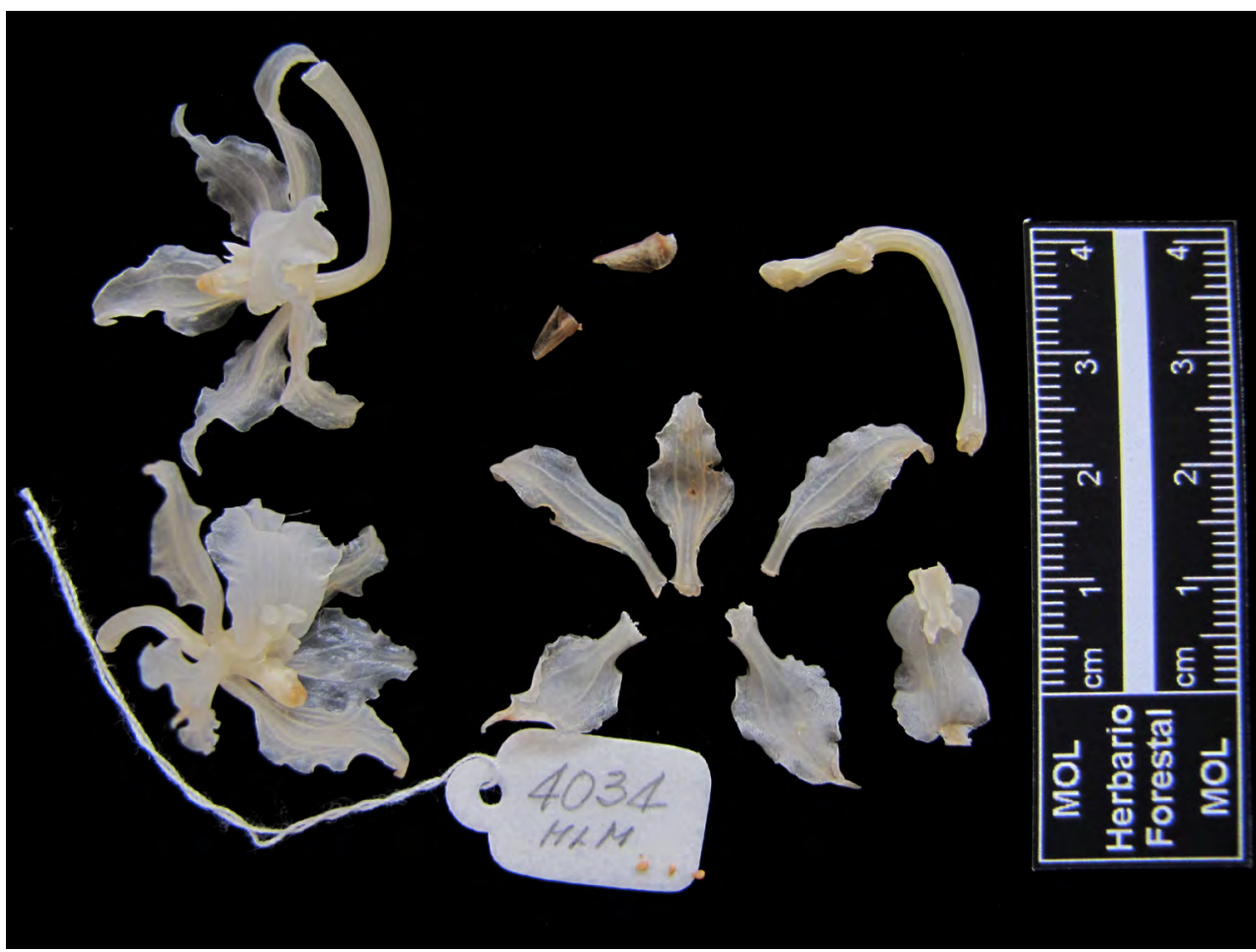

Figure 51. Odontoglossum machupicchuense D.E.Benn. \& Christenson. Holotype at MOL (M. León 4034 in spirit). Photo: D. Trujillo.

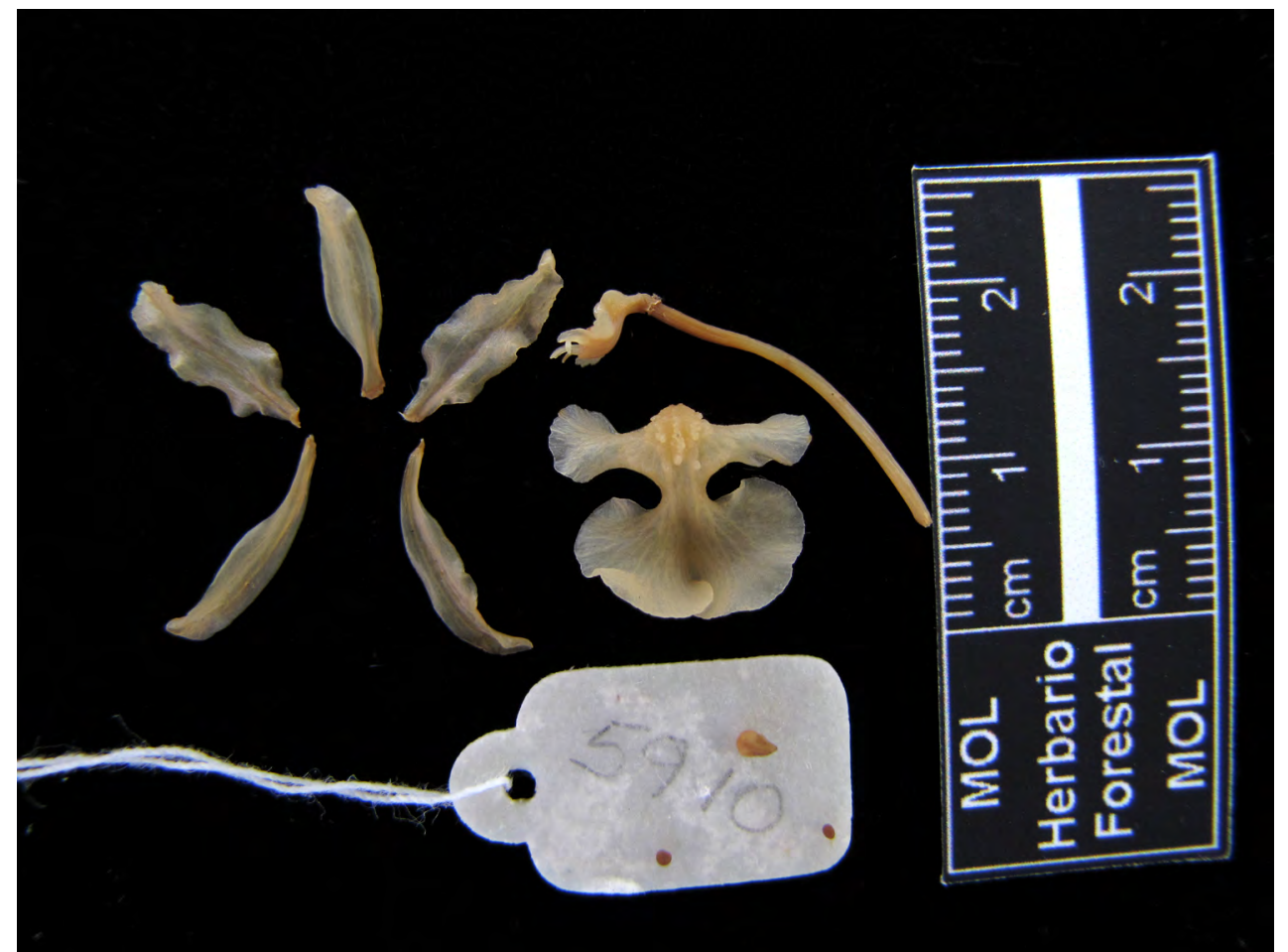

Figure 52. Oncidium ayabacanum D.E. Benn. \& Christenson. Holotype at MOL (Bennett 5910 in spirit). Photo: D. Trujillo. LANKESTERIANA 14(1), April 2014. (C) Universidad de Costa Rica, 2014. 
the protologue is erroneous and is corrected here.

Oncidium exasperatoides D.E.Benn. \& Christenson, Icon. Orchid. Peruv.: t. 735. 2001.

TYPE: Peru, Pasco, above Yaupi along the road to Paucartambo, 2000 m, 26 Feb 1989, D. Bennett, A. Bennett \& G. Bennett 4517. Holotype: originally deposited at Herb. Bennettianum, now at MOL.

Oncidium miradorense D.E.Benn. \& Christenson, Lindleyana 13: 80. 1998.

TYPE: Peru, Huanuco, Leoncio Prado, below Mirador, 1550 m, 6 Jun 1989 [prepared on 19 June 1989], leg. E. Jara P., Bennett 4539. Holotype: according to the protologue at USM, now deposited at MOL.

Basionym of: Cyrtochilum miradorense (D.E.Benn. \& Christenson) Dalström, Lindleyana 17: 91. 2002. nom. inval. [Without basionym reference], [see below: Validation of New Combinations].

The specimen was prepared on June 19, 1989 and agrees with the illustration of the original publication.

Oncidium pastorellii Dodson \& D.E.Benn., Icon. P1. Trop., II, 2: t. 137. 1989.

TYPE: Peru, Huanuco, Huanuco, Carpish Pass along road to Tingo Maria, 2800 m, 6 Nov 1986, Bennett 3522. Holotype: MO, lost. Lectotype here designated: Peru, Huanuco, Huanuco, along road below Carpish, 2800 m, 18 Nov 1985 D. Bennett et al. 3522-2 (MO).

Synonym of: Cyrtochilum cordatum (Lindl.) Kraenzl, proposed by Dalström (2001).

Three pressed specimens of Bennett 3522 with different suffixes and dates of preparation were found at two herbaria (MO and MOL). Two specimens of Bennett 3522-1 prepared on November 18, 1985 and on November 6, 1986 (respectively) are in the Bennett collection at MOL (the latest preparation date agrees with that cited in the protologue). One specimen of Bennett 3522-2 prepared on November 18, 1985 is at MO. The specimen at MO is designated as the holotype; however its date of preparation disagrees with that given in the protologue. The collection number with suffix of none of the specimens (at MO and MOL) was cited in the protologue; although apparently the authors used all these specimens for describing the species.

In absence of the holotype, a lectotype is designated here. The specimen chosen is the most complete specimen conserved at MO (ICN. 9A.3).

Ornithocephalus aurorae D.E.Benn. \& Christenson, Lindleyana 13: 80. 1998.

TYPE: Peru, Cuzco, Quillabamba, District of Quirimbiri, Comunidad San Pantuari, 909 m, leg. O. del Castillo, 28 Sep 1995, Bennett 7245. Holotype: NY, lost; Isotype: USM, lost. Lectotype here designated: Peru, Cusco, Quillabamba, District of Quirimbiri, Comunidad Nativa Pantuari, 909 m, leg. O. del Castillo, 28 Sep 1995, Bennett 7245-2. (MOL; Isolectotype: MOL-spirit).

The type specimens were not found at NY (T. Zanoni, pers. comm.) or at USM. The original material of Ornithocephalus aurorae found in the Bennett collection at MOL consists of two preparation of Bennett 7245-2: one pressed and one in spirit. The Table Records of the illustrated Bennett's specimens indicates that the illustration of the species was prepared based on the specimen Bennett 7245-2.

Both preparations were made on September 28 1995 (date that agrees with the protologue); however, as there is not an annotation that indicates that they are part of a single sample; they represent two different specimens (ICN. Art. 8.3). In absence of the holotype, a lectotype is designated here from among the specimens that comprise the original material (ICN. Art. 9.12). The specimen here chosen is the most completed (pressed) specimen.

Ornithocephalus caveroi D.E.Benn. \& Christenson Icon. Orchid. Peruv.: t. 737. 2001.

TYPE: Peru, Puno, Carabaya, district of Coasa, Candamo valley, 500 m, 15 Sept 1998, M. Cavero B. ex Bennett 7838. Holotype: originally deposited at Herb. Bennettianum, now at MOL[-spirit] (Fig. 54).

The whole plant is preserved in alcohol.

Fernandezia pastorelliae D. Trujillo. sp. nov.

Similar to Fernandezia gracillima (C. Schweinf.) M.W. Chase but differs in having the trilobed lip and the floral tube formed by the connate sepals 
TYPE: Peru, Junin, Satipo, Monobamba, 2200 m, 2 May 1996, O. del Castillo ex Bennett 7501. Holotype: MOL.

Pachyphyllum aurorae D.E.Benn. \& Christenson, Icon. Orchid. Peruv.: t. 546. 1998. nom. inval. [no holotype designated]. Type: Peru, Junin, Chanchamayo, 2700 m, 12 Apr 1996, O. del Castillo ex Bennett 7501. NY, USM.

Pachyphyllum aurorae D.E.Benn. \& Christenson, J. Bot. Res. Inst. Texas 2: 287. 2008. nom. inval. [lectotype was designated erroneously rather than holotype]. Type: Peru, Chanchamayo, 2700 m, 12 Apr 1996, O. del Castillo ex Bennett 7501. Lectotype: MOL; Isolectotype: NY.

Fernandezia aurorae (D.E.Benn. \& Christenson) M.W.Chase, Phytotaxa 20: 29. 2011. nom. inval. [basionym not valid]

Pachyphyllum aurorae was invalidly published by Bennett \& Christenson (1998) (contrary to St. Luis Code Art. 37.6 ICBN, Greuter et al. 2000; Melbourne Code Art. 40.7 ICN, McNeill et al. 2012); although two specimens of Bennett 7501 were indicated, neither was designated as holotype. Christenson (2008) attempted to correct this by designating a lectotype; however the name was not validated. The Vienna Code Art. 37.6 ICBN (McNeill et al. 2006) and Melbourne Code Art. 40.6 ICN, (McNeill et al. 2012) specified that an attempted validation of this type require the use of the term "type" or "holotype (or their equivalents) (see also ICN Art 40.6 Ex. 5). Later this Pachyphyllum was transfered to the genus Fernandezia by Chase (in Chase \& Whitten 2011). But the new combination made by Chase was not valid because the basionym had not yet been validly published (ICN. Art. 41.5). Because the taxon was not validly described before, I validate it here, under the genus Fernandezia as was proposed by Chase (in Chase \& Whitten 2011) and using the epithet "pastorelliae" in honour of Aurora Pastorelli (to whom was originally dedicated the taxon).

Additional to the specimen Bennett 7501; designated here as holotype of Fernandezia pastorelliae, there are other two specimens of Bennett 7501 in the Bennett collection at MOL; one in spirit and one pressed. Those specimens do not have a collection date or an annotation that indicates that they are duplicates of the specimen here designated as holotype; therefore they are not isotypes.
Pachyphyllum ecallosum D.E.Benn. \& Christenson, Icon. Orchid. Peruv.: t. 738. 2001.

TYPE: Peru, Dept. Huancavelica, Tayacaja, Dist. Huachocolpa, Capcasorqo, 3400 m, 15 Jun 1999 [date of preparation $21 \mathrm{Jul}$ 1999], M. León M. 3067. Holotype: MOL, part in spirit (x2).

Basionym of: Fernandezia ecallosa (D.E.Benn. \& Christenson) M.W.Chase, Phytotaxa 20: 30. 2011.

The field work report of M. León et al. indicates that (only) a living specimen of M. León et al. 3067 was collected on 14-16 June 1999.

Three preparations of M. León 3067 were found in the Bennett collection at MOL: two in spirit and one pressed prepared on July 21, 1999. These specimens were prepared from the living plant collected by M. León et al. An annotation in the pressed specimen indicates that there is a plant with flowers in spirit. Therefore those specimens in spirit are not duplicates; if not part of the holotype.

The correct elevation data is cited in the protologue; which is the same that indicated in the field report of M. León et al. On the label of the pressed specimen (MOL), David Bennett wrote a different elevation: "2800-3200 m"; this is erroneous.

Ponthieva collantesii D.E. Benn. \& Christenson, Icon. Orchid. Peruv.: t. 556. 1998.

TYPE: Peru, Cusco, Urubamba, Santuario Historico de Machupicchu, Camino Inca toward Phuyupatamarca, 3000 m, 11 May 1998, B. Collantes M. ex Bennett 7821. Holotype: USM, lost. Lectotype here designated: Peru, Cusco, Cusco, Camino Inca toward Phuyupatamarca, 3000 m, 2 Jul 1998, B. Collantes M. ex Bennett 7821 (MOL).

The holotype was not found at any Peruvian herbarium. However, two specimens of Bennett 7821 found in the Bennett collection at MOL were prepared on different dates and mounted on a single sheet. One specimen consists of a dissected flower prepared on May 21, 1998, the other is a whole plant with flowers prepared on July 2 1998. The dates of preparation of both specimens disagree with that given in the protologue; however they represent original material. In absence of the holotype, a lectotype is designated here (ICN. Art. 9.2). The specimen chosen as lectotype 
is the most complete pressed specimen from the original material (ICN. Art. 9.12).

There is an additional specimen of $B$. Collantes $s n$. (Ponthieva collantesii) at USM; however, this is not part of the original material because it was prepared on April 1999 (after the species publication).

Prosthechea hajekii D.E.Benn. \& Christenson, Icon. Orchid. Peruv.: t. 750. 2001.

TYPE: Peru, Junin, Chanchamayo, up the steep canyon oriented NW of the road $8 \mathrm{kms}$ before San Ramon, 1800 m, 11 Nov 1998 [prepared on 1 Sept 1999], C Hajek \& F. Hajek ex Bennett 7938. Holotype: originally deposited at Herb. Bennettianum, now at MOL, part in spirit.

The specimens were prepared on September 1, 1999. David Bennett wrote on the label of the pressed preparation: "sp.nov" and "LAM-1394".

Rodriguezia delcastilloi D.E. Benn. \& Christenson, Brittonia 46: 42. 1994.

TYPE: Peru, Pasco, Oxapampa, District of Puerto Bermudez, Cuidad de Constitucion, along road between Pt. Bermudez and Pucalpa, $250 \mathrm{~m}, 10 \mathrm{Nov}$ 1991, O. del Castillo ex Bennett 5382. Holotype: NY!; [Isotype: MOL-spirit].

Rodriguezia satipoana Dodson \& D.E.Benn., Icon. P1. Trop., II, 2: t. 165. 1989.

TYPE: Peru, Junin, Satipo, 800 m, 16 Oct 1985, Bennett 3542. Holotype: MO, lost.

Lectotype here designated: Peru, Junin, (Jauja?), several kms above Satipo towards Huancayo 700 to $800 \mathrm{mts}, 17$ Oct 1985, D. Bennett \& A. Bennett 3542 (MOL).

Three pressed specimens of Bennett 3542 with different dates of preparation were found at three herbaria: MO, NY and in the Bennett collection at MOL; and apparently the authors used all these specimens for describing the species. The specimen at $\mathrm{MO}$ is assigned as holotype; but has a different locality data and date of preparation that given in the protologue. The specimen at MOL is also assigned as holotype (Bennett's handwritten annotation) but has a different locality data and date of preparation that given in the protologue The specimen at NY is assigned as isotype; but the locality data disagrees with that given in the protologue. As there is not a clear holotype, a lectotype is designated here (ICN. Art. 9.2). The specimen chosen as lectotype is the specimen conserved at MOL that has the annotation of David Bennett (ICN. 9A.3).

It seems that the specimens were collected from different localities (populations). This idea is supported by the locality data written on the labels of the specimens at MO and NY.

Rusbyella suarezii D.E.Benn. \& Christenson, Icon. Orchid. Peruv.: t. 753. 2001.

TYPE: Peru, Huancavelica, Huachocolpa, 2900 m, 10 June 1999, R. Suarez \& G. Alegria ex Bennett 7910. Holotype: originally deposited at Herb. Bennettianum, now at MOL[-spirit] (Fig. 55).

R. Suarez \& G. Alegria ex Bennett 7910 in spirit was found in the Bennett collection at MOL; however, as pressed preparation was not located in any Peruvian herbarium. The spirit specimen, consisting of two flowers (one dissected) that agree with the illustration of the original publication is the holotype.

Scelochilus campoverdei D.E.Benn. \& Christenson, Brittonia 46: 256. 1994.

TYPE: Peru, Pasco, Oxapampa, District Villarica, Cumbre de Bocaz, 13 Mar 1993, [prepared on 18 May 1993], J. E. Campoverde ex Bennett 6151. Holotype: NY!, [Isotype: MOL-spirit].

Basionym of: Comparettia campoverdei (D.E.Benn. \& Christenson) M.W.Chase \& N.H.Williams, Lindleyana 21: 29. 2008.

The specimen was prepared on May 18, 1993.

Scelochilus crucicornibus Senghas, D.E.Benn. \& Christenson, Brittonia 50: 183. 1998.

TYPE: Peru, Pasco, Oxapampa, Pozuzo, 1200 m, J. del Castillo ex D. Bennett 7718-3. [7718., in error]: Holotype: according to the protologue at USM, now deposited at MOL; Isotype: NY, lost.

Basionym of: Comparettia crucicorniba (Senghas, D.E.Benn. \& Christenson) M.W.Chase \& N.H.Williams, Lindleyana 21: 29. 2008. 
The specimen has no locality data on the label, only the date of preparation (January 19, 1997) and an annotation of David Bennett that indicates that it is the holotype.

Scelochilus delcastilloi D.E.Benn. \& Christenson, Icon. Orchid. Peruv.: t. 567. 1998.

TYPE: Peru, Junin, San Ramon, $9 \mathrm{~km}$ south of town on the west side of Rio Tulumayo, 1800 m, 15 May 1992, O. del Castillo ex Bennett 5639. Holotype: according to the protologue at USM, now deposited at MOL[spirit] (Fig. 56). Paratype: Peru, Pasco, Oxapampa, Villarica, Rio Sal, 1982 m, Aug 1993, J. Campoverde ex Bennett 6415. Paratype: according to the protologue at USM, now deposited at MOL[-spirit].

Basionym of: Comparettia delcastilloi (D.E.Benn. \& Christenson) M.W.Chase \& N.H.Williams, Lindleyana 21:29. 2008.

O. del Castillo ex Bennett 5639 in spirit was found in the Bennett collection at MOL; however, a pressed preparation was not located in any Peruvian herbarium. The specimen in spirit, consisting of three dissected flowers that agree with the illustration of the original publication is the holotype.

An additional pressed specimen of Scelochilus (delcastilloi), prepared on September 21, 1992, was found in the Bennett collection at MOL); but with two collection numbers: Bennett 5639-1 \& Bennett 5639-2.

Sobralia altissima D.E.Benn. \& Christenson, Orchids 68: 1112. 1999.

TYPE: Peru, Huancavelica, Tajacaya, Huachocolpa district, Inquilpata, $13 \mathrm{Feb} 1999$ [18 Feb, in error], 2800-2900 m, M. León M et al. 2960 [2962, in error]. Holotype: originally deposited at Herb. Bennettianum, now at MOL; Isotype: MOL, [USM].

The protologue cites "MLM-2962" as the type specimen of Sobralia altissima. However, the report of M. León indicates "MLM-2962" as Lepanthes sp. (MOL!) and "MLM-2960" as Sobralia sp.. Additionally, the field notes (flowers features) of "MLM-2960" agree with Sobralia altissima; therefore the original type citation in the protologue is erroneous and is corrected here. The report of M. León et al. also indicates that they prepared both pressed and spirit specimens of MLM-2960 (Sobralia altissima).

One pressed specimen of M. León 2960 found unmounted and without a label in the Bennett collection, but with the collection number, is the holotype.

Two duplicate specimens of M. León M et al. 2960 (isotypes) were deposited by the collectors at MOL and USM. The specimen at MOL is mounted without a label. The specimen at USM is mounted with a label; the collection data of this specimen agree with that given in the protologue.

Five additional specimens of Sobrallia altissima were found in the Bennett collection at MOL: one in spirit and four pressed. These specimens are labeled as: "M. León \& B. Collantes sn, ex Bennett 7867". The pressed specimens have different dates of preparation: February 20, 1999, February 26, 1999 and February 27, 1999 (x2). All disagree with that given in the protologue. The specimen in spirit has the label with the handwriting of David Bennett, but lacks a preparation date. These additional specimens are part of the original material.

Sobralia hirta D.E.Benn. \& Christenson, Icon. Orchid. Peruv.: t. 762. 2001.

TYPE: Peru, Pasco, Oxapampa, ca. 14 km NW of Oxapampa city, near the Hacienda San Isidro, $1885 \mathrm{~m}$, 6 Apr 1992, O. del Castillo ex Bennett 5546. Holotype: Herb. Bennettianum [now at MOL], lost [See below]. LEстотуре here designated: Peru, without locality data [probably same as in the protologue], $O$. del Castillo ex Bennett 5546 (MOL-spirit; Fig. 57).

The holotype was not found at MOL. The original material of Sobralia hirta found in the Bennett collection at MOL comprises of two specimens of Bennett 5546; one pressed and one in spirit. The pressed specimen is sterile and was prepared on April 8, 1992; but this date disagrees with that given in the protologue. The specimen in spirit consists of a dissected flower and has no date of preparation. The dissected flower agrees with the illustration of the original publication. The illustration was prepared on April 7, 1992, and probably on this date the specimen in spirit was prepared.

In absence of the holotype, a lectotype is designated here (ICN. Art. 9.2). The specimen chosen as lectotype is the specimen in spirit (ICN. 9A.2). 


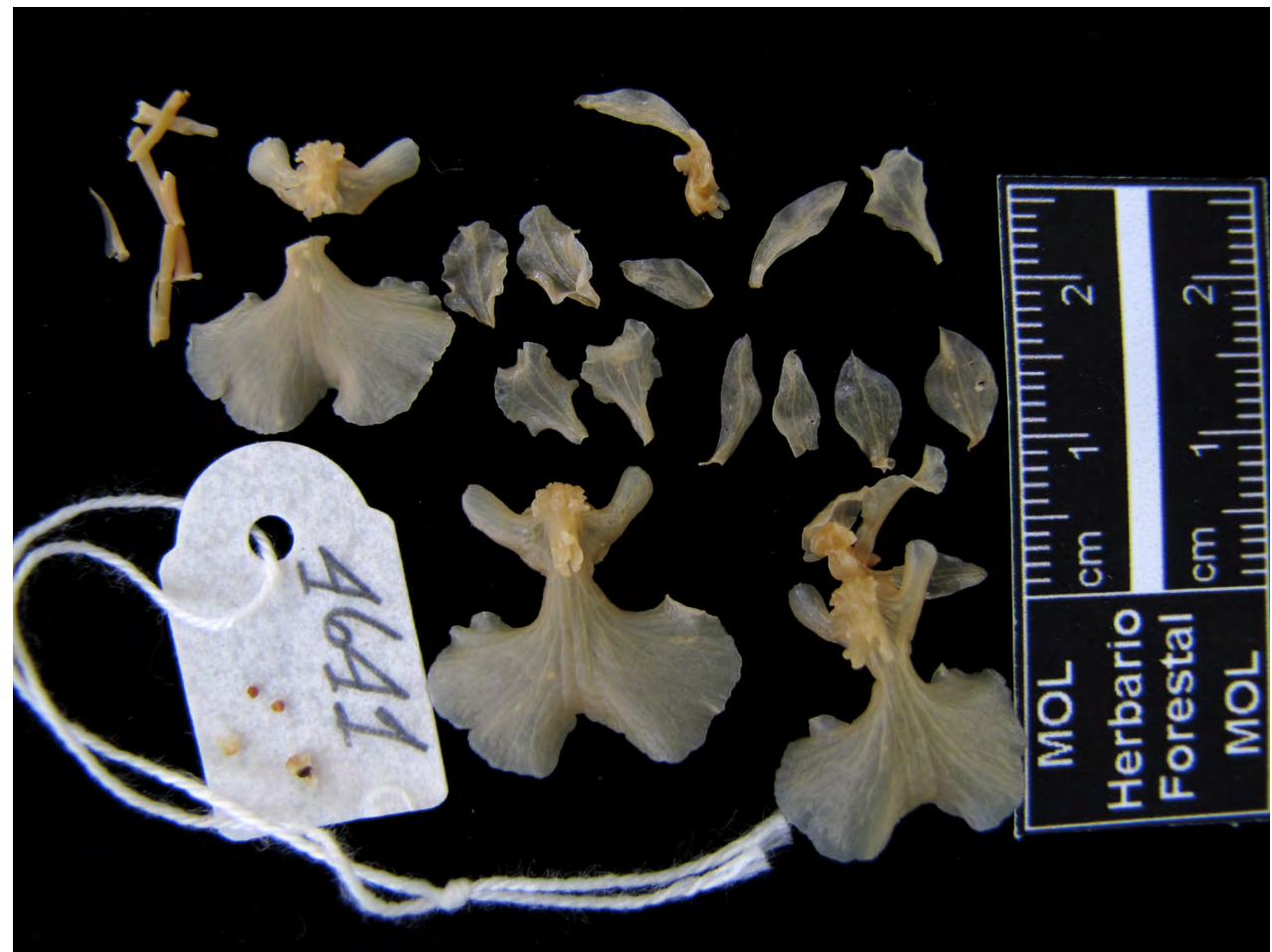

Figure 53. Oncidium bennettii Christenson. Lectotype at MOL (Bennett 4641 in spirit). Photo: D. Trujillo.

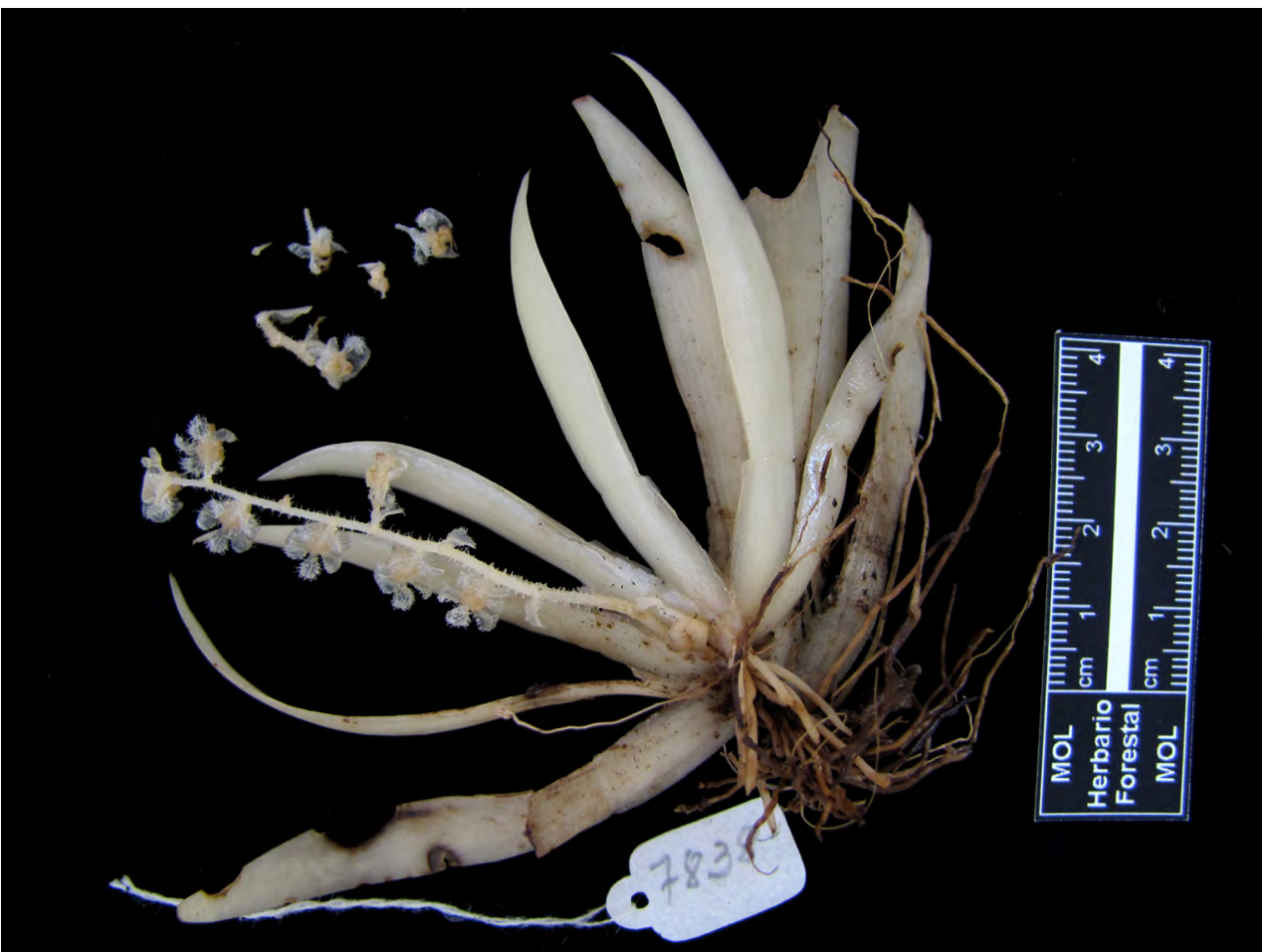

Figure 54. Ornithocephalus caveroi D.E.Benn. \& Christenson. Holotype at MOL (Bennett 7838 in spirit). Photo: D. Trujillo. 


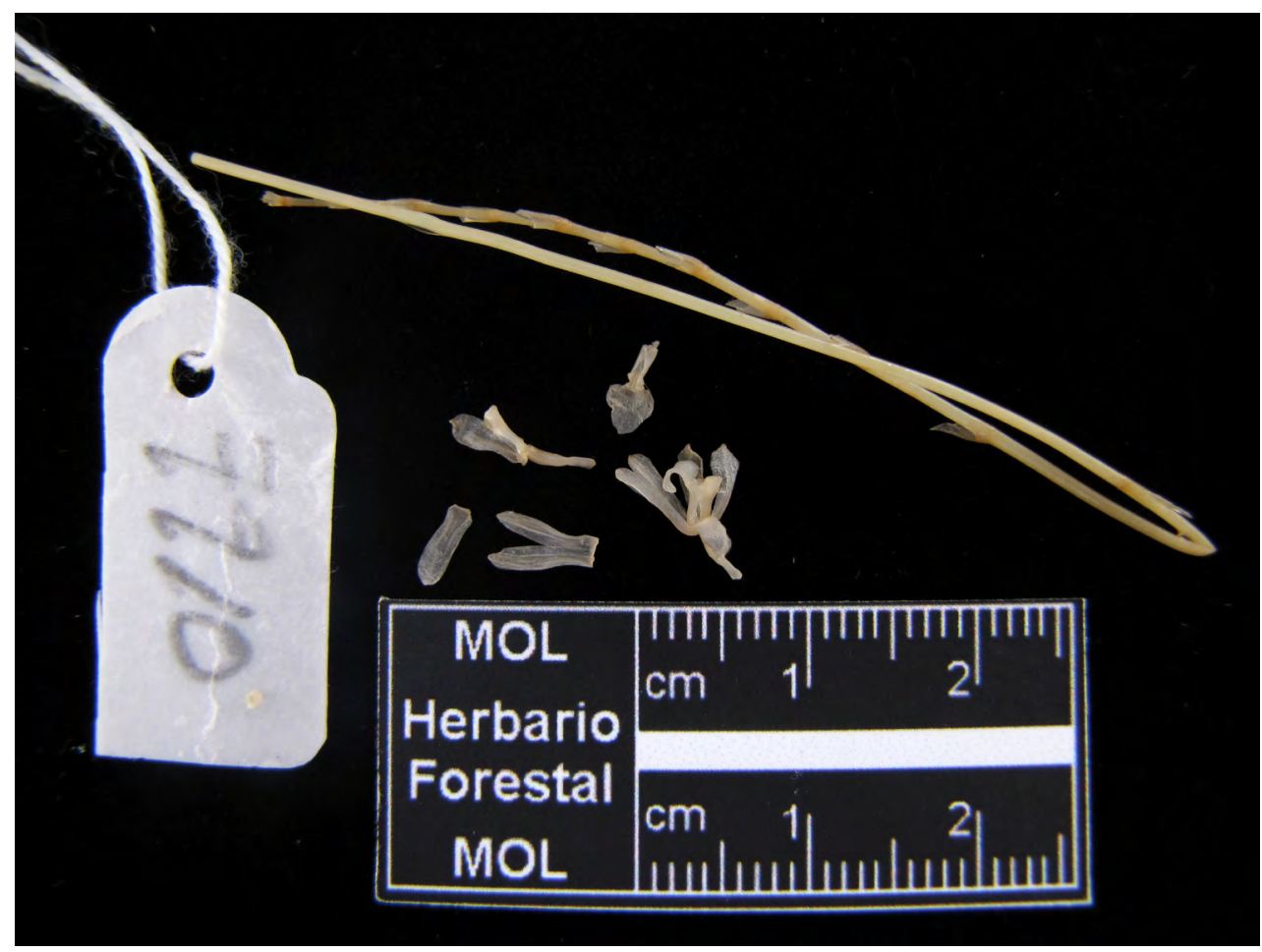

Figure 55. Rusbyella suarezii D.E.Benn. \& Christenson. Holotype at MOL (Bennett 7910 in spirit). Photo: D. Trujillo.

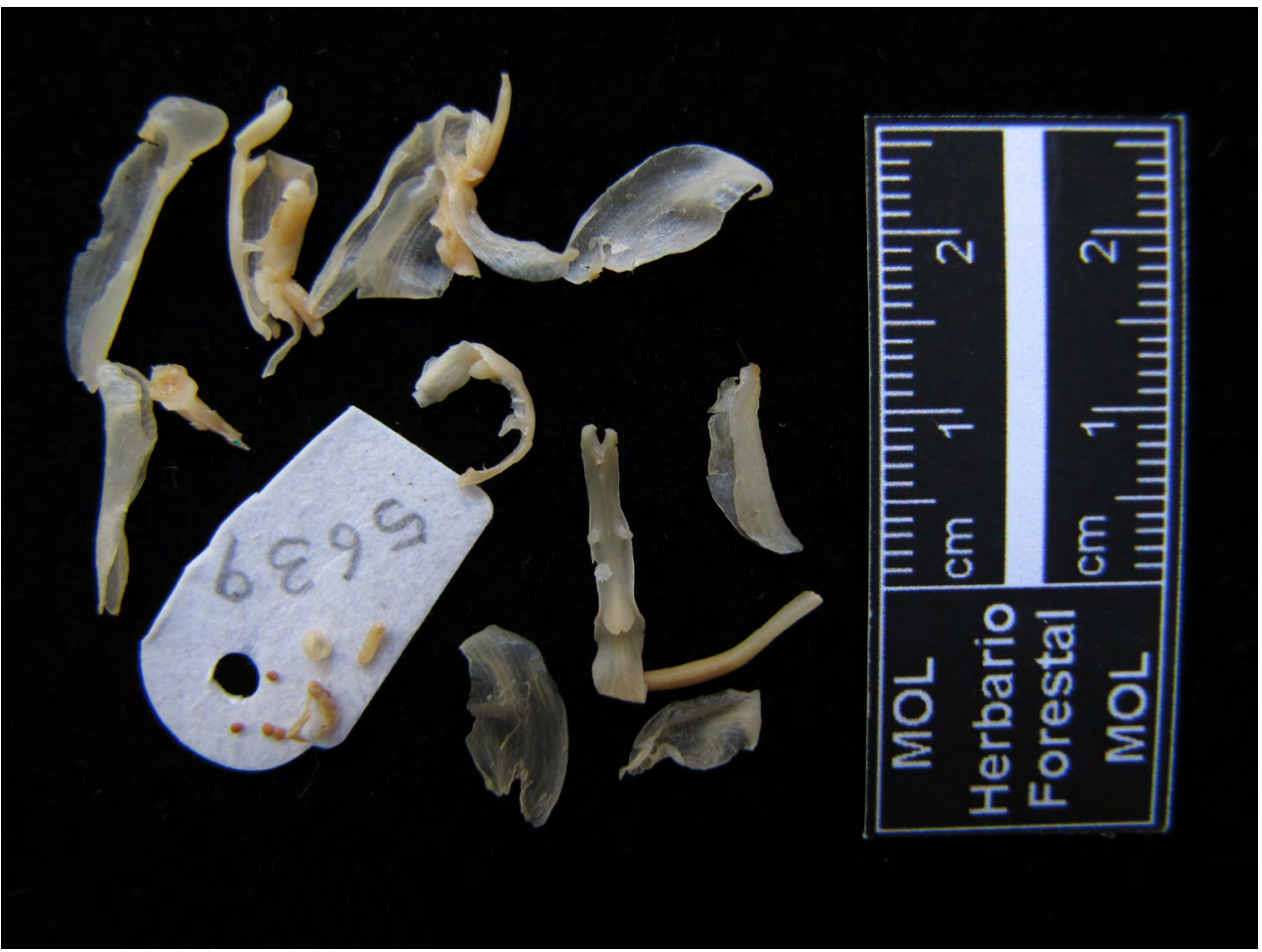

Figure 56. Scelochilus delcastilloi D.E.Benn. \& Christenson. Holotype at MOL (Bennett 5639 in spirit). Photo: D. Trujillo. LANKESTERIANA 14(1), April 2014. (c) Universidad de Costa Rica, 2014. 


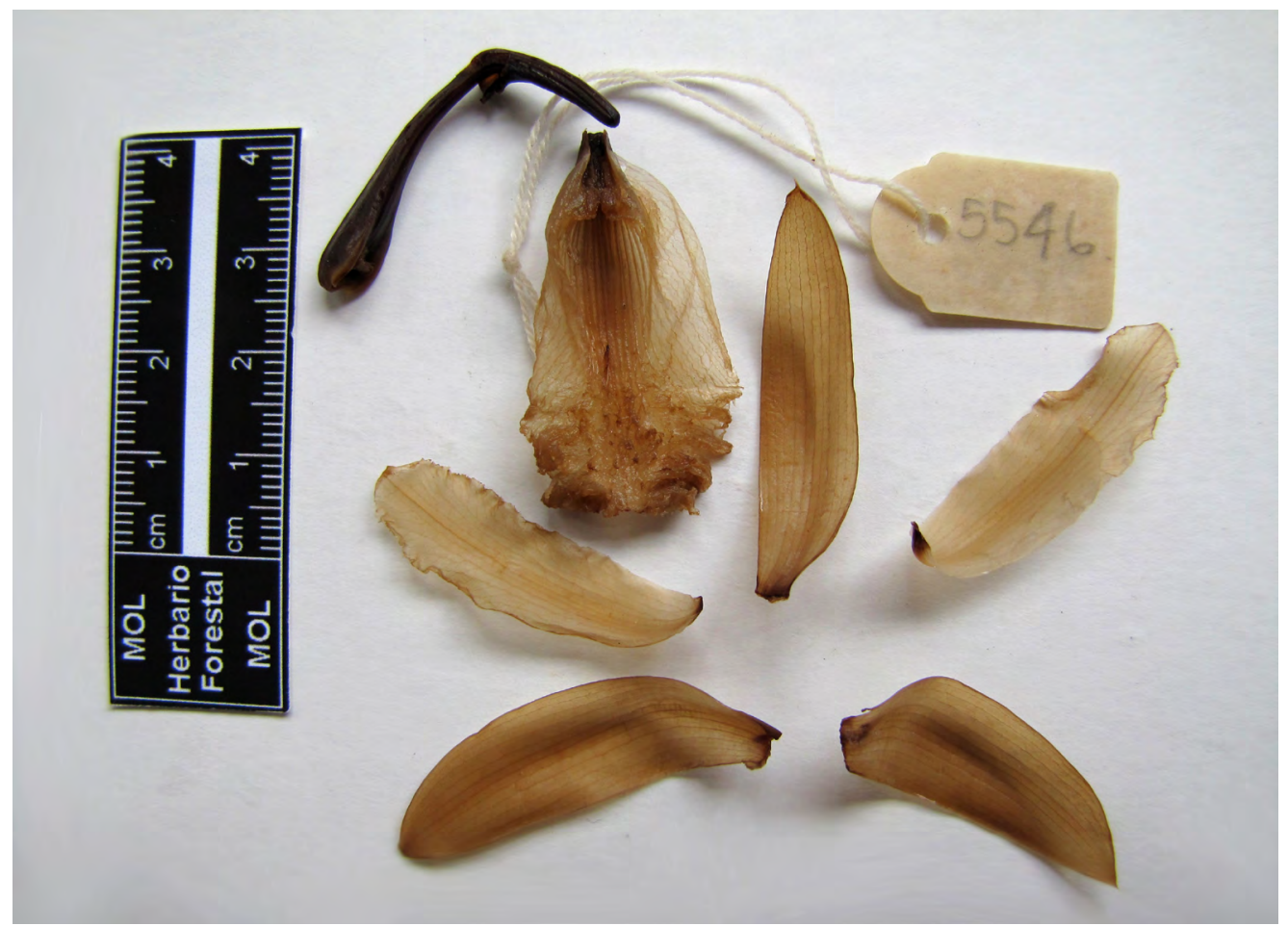

Figure 57. Sobralia hirta D.E.Benn. \& Christenson. Lectotype at MOL (Bennett 5546 in spirit). Photo: D. Trujillo.

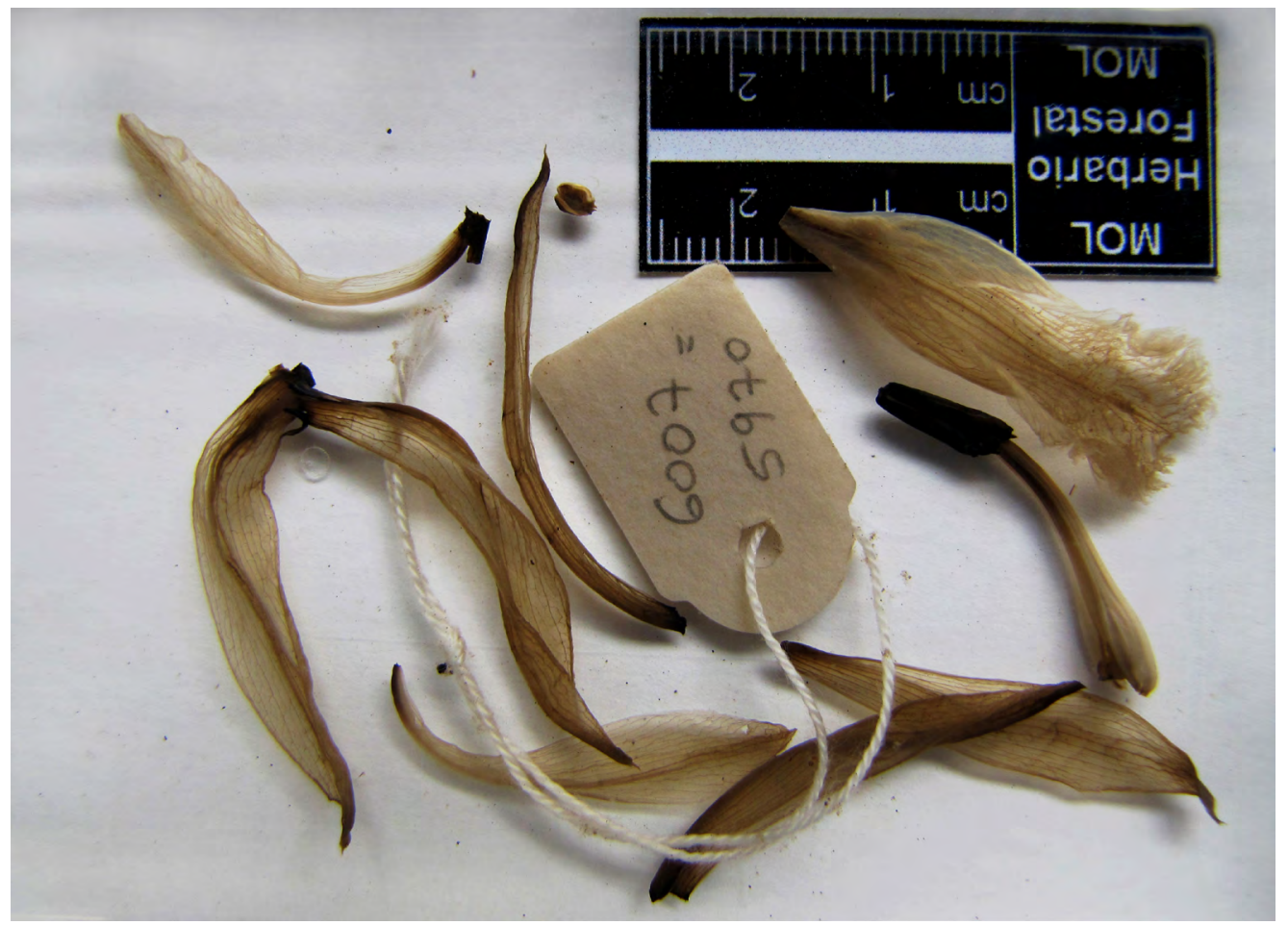

FiguRE 58. Sobralia withneri D.E.Benn. \& Christenson. Holotype at MOL (Bennett 6007 in spirit). Photo: D. Trujillo. LANKESTERIANA 14(1), April 2014. (C) Universidad de Costa Rica, 2014. 


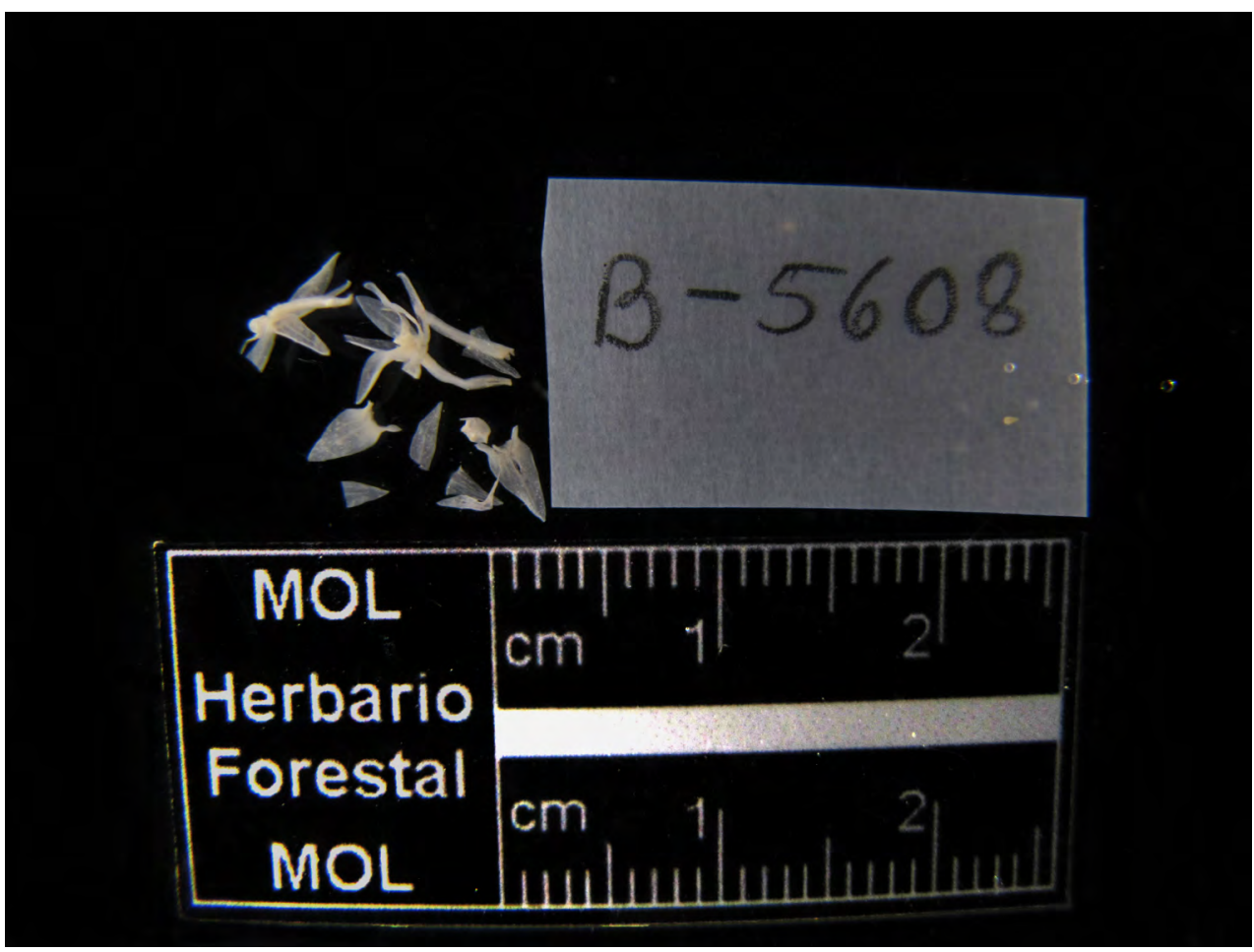

Figure 59. Stellilabium peruvianum D.E.Benn. \& Christenson. Lectotype at MOL (Bennett 5608 in spirit). Photo: D. Trujillo.

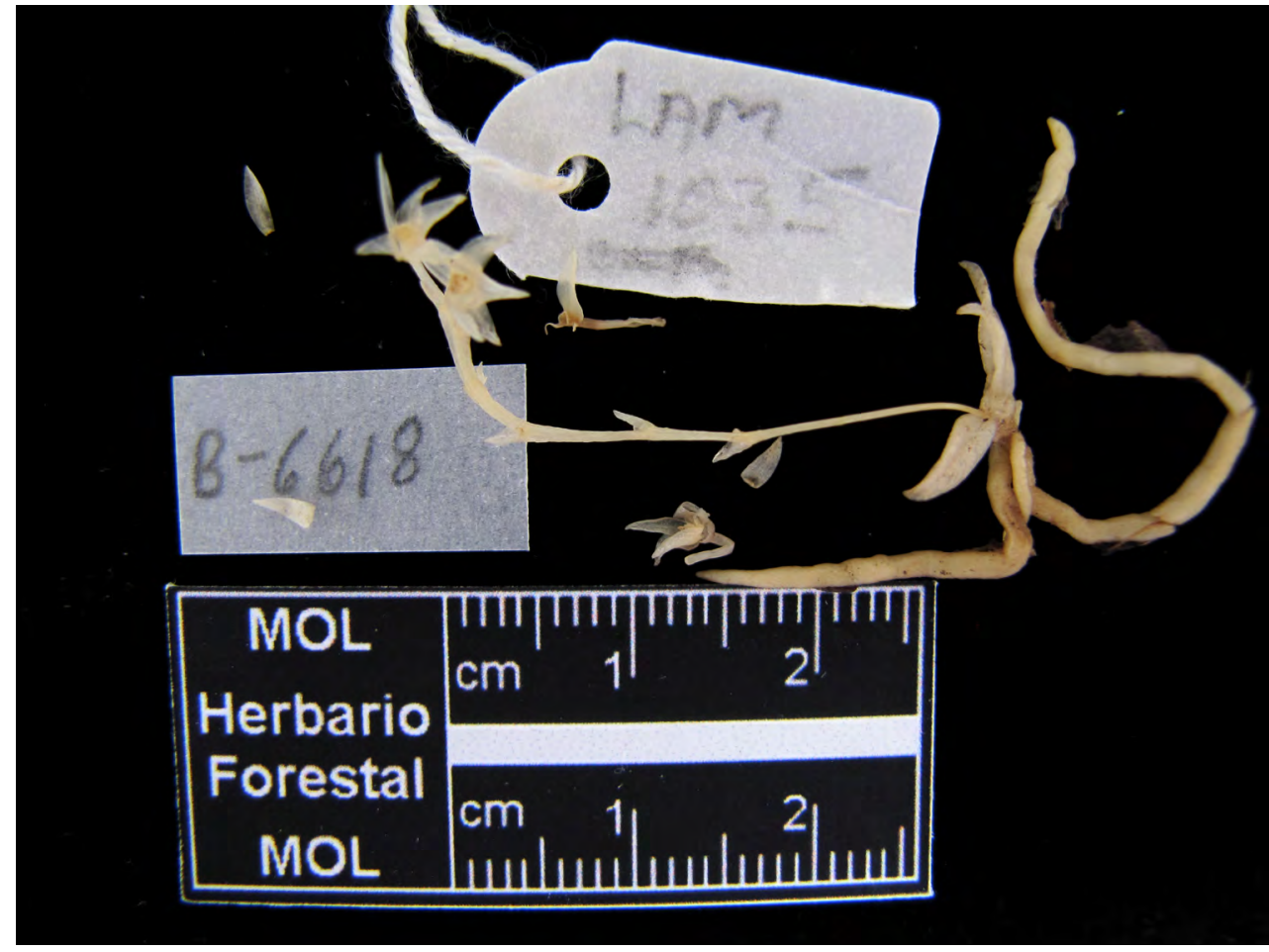

Figure 60. Stellilabium pseudobulbosum D.E.Benn. \& Christenson. Holotype at MOL (Bennett 6618 in spirit). Photo: D. Trujillo. LANKESTERIANA 14(1), April 2014. (c) Universidad de Costa Rica, 2014. 
Sobralia ruparupaensis D.E.Benn. \& Christenson, Icon. Orchid. Peruv.: t. 763. 2001.

TYPE: Peru, Huanuco, Leoncio Prado, District Rupa Rupa, near Jacintillo along road to Monzon, ca. 700$750 \mathrm{~m}$ [750 m, in error], 24 Mar 1987, J. Schunke V. 14237. Holotype: according to the protologue at USM, now deposited at MOL [SynTYPES, see below]. Lectotype here designated: Peru, Huanuco, Leoncio Prado, District Rupa Rupa, near Jacintillo along road to Monzon, ca. 700-750 m, 24 Mar 1987, J. Schunke V. 14237 (MOL; Isolectotype: MOL [x26]).

Type specimens were deposited at MOL by David Bennett on 2001 and were never at USM.

Twenty seven pressed specimens of $J$. Schunke $V$. 14237 were found in the Bennett collection at MOL. None of the specimens is annotated as the holotype. Therefore the 27 specimens found in the Bennett collection represent syntypes (ICN. Art. 40 Note 1 ). In absence of the holotype, a lectotype is designated here (ICN. Art. 9.2). The specimen here chosen as lectotype is the most complete pressed specimen.

Sobralia withneri D.E.Benn. \& Christenson, Icon. Orchid. Peruv.: t. 764. 2001.

TYPE: Peru, Ucayali, Aguaytia, $1 \mathrm{~km}$ south on the Aguaytia river from the road between Pucalpa and Tingo Maria, 300 m, 30 Dec 1992, O. del Castillo ex Bennett 6007. Holotype: originally deposited at Herb. Bennettianum, now at MOL[-spirit] (Fig. 58).

O. del Castillo ex Bennett 6007 in spirit was found in the Bennett collection at MOL; however, a pressed preparation was not located. The spirit specimen is a dissected flower that agrees with the illustration of the original publication and is the holotype.

Bennett wrote on the label of the specimen: "= 5970" (see Fig. S58); this annotation indicates that the specimen Bennett 5970 correspond to the same species of Bennett 6007.

Sphyrastylis garayi D.E.Benn. \& Christenson, Lindleyana 13: 83. 1998.

TYPE: Peru, Pasco, Oxapampa, Dist. Huancabamba, sector San Danieli, 2000 m, leg. O. Del Castillo, flowered by E. Edwards, 5 Aug 1995; Bennett 7218. Holotype: according to the protologue at USM, now deposited at MOL, [Isotype: MOL-spirit].

Basionym of: Ornithocephalus garayi (D.E.Benn. \& Christenson) Toscano \& Dressler, Lindleyana 15: 2552000 .

The preparation in spirit of Bennett 7218 is an isotype (duplicate) because there is not an annotation on the label of the pressed specimen that indicates that the preparation in spirit is part of the same specimen (ICN. Art. 8.3).

Stellilabium peruvianum D.E.Benn. \& Christenson, Lindleyana 13: 86. 1998.

TYPE: Peru, Junin, Chanchamayo, Arcopunco, 2000 m, leg. O. del Castillo, 4 June 1992, Bennett 5608. Holotype: NY, lost; [Isotype: MOL-spirit, designated here as Lectotype] (Fig. 59).

Basionym of: Telipogon selbyanus N.H.Williams \& Dressler, Lankesteriana 5: 171. 2005.

The holotype was not found at NY (T. Zanoni, pers. comm.). The extant isotype (in spirit) found in the Bennett collection at MOL, consisting of two intact and one dissected flowers, is here designated as lectotype (ICN. Art. 9.12).

Stellilabium pseudobulbosum D.E.Benn. \& Christenson, Lindleyana 13: 88. 1998.

TYPE: Peru, Pasco, Oxapampa, Parque Nacional Yanachaga-Chemillen [Chemillin, in error] near Quebrada Tunqui, $1800 \mathrm{~m}$, leg. M. Cavero B., 7 Apr 1994, Bennett 6618. Holotype: according to the protologue at NY, now deposited at MOL[-spirit] (Fig. 60).

Basionym of: Telipogon pseudobulbosus (D.E.Benn. \& Christenson) N.H.Williams \& Dressler, Lankesteriana 5: 171. 2005.

The holotype was deposited at MOL by David Bennett on 2001 and never at NY. The holotype consists of a whole plant preserved in alcohol (the specimen agrees with the illustration of the original publication).

Stenia aurorae D.E.Benn. \& Christenson, Lindleyana 13: 91.1998.

TYPE: Peru, Junin, Tarma, between Carapata and 
Huasahuasi, 2200 m, leg. O. del Castillo, 2 Aug 1994, Bennett 6640. Holotype: USM, Lost; Isotype: NY, lost. LeстотуPE here designated: Peru, without locality data [probably same as in the protologue], Bennett 6640 (MOL-spirit; Fig. 61).

The holotype was not found in any Peruvian herbarium. A pressed specimen of Bennett 6640 -annotated as Isotype- was found at NY; however the date of preparation (September 7, 1994) disagrees with that given in the protologue. A specimen in spirit of Bennett 6640 was found in the Bennett collection at MOL; the specimen has a Bennett's annotation that indicates: "Stenia sp. nov" but has no date of preparation. The specimen in spirit is a dissected flower that agrees with the illustration of the original publication. The illustration was prepared on August 18, 1994; probably on the date the specimen in spirit was prepared. In absence of the holotype, a lectotype is designated here (ICN. Art. 9.2). The specimen chosen as lectotype is the specimen in spirit conserved at MOL (ICN. 9A.2, 9A.3).

Stenia christensonii D.E. Benn., Brittonia 50: 189. 1998.

TYPE: Peru, Pasco, Oxapampa, Puerto Bermudez, Sector Milagros along Pichis River, coll. 10 Nov 1991, 280 m, leg. O. del Castillo, Bennett 5387. Holotype: NY, lost; Isotype: USM, lost. Paratype: Peru, Pasco, Oxapampa, Villarica, Canal de Piedra, $1830 \mathrm{~m}$, leg. O. del Castillo, flowered in cultivation by E. Edwards, 11 Sep 1994, Bennett 6745. Paratype: USM, lost. LестотуPE here designated: Peru, without locality data [probably same as in the protologue], Bennett 5387 (MOL-spirit; Fig. 62).

The cited isotype (Bennett 5387) was not found at USM. At NY, there are two pressed specimens (only pressed flowers) of Stenia christensonii with different numbers: Bennett 5387 prepared on September 24, 1992 (NY-1477197) and Bennett 6387 prepared on October 11, 1994 (NY-39386). The latter was designated as holotype (probably by Bennett); however the collection number and date of preparation disagree with that given in the protologue, and therefore this cannot be the holotype.

A specimen of Bennett 5387 in spirit is in the Bennett collection at MOL; the specimen consists of a dissected flower that agrees with the illustration of the original publication. The illustration was prepared on September 1, 1994; probably on this date the specimen in spirit was prepared. In absence of the holotype, a lectotype is designated here (ICN. Art. 9.2). The specimen chosen as lectotype is the specimen in spirit conserved at MOL (ICN. 9A.2).

Bennett 6745, the paratype of $S$. christensonii was not found at USM. However, Bennett 6745-2 -a clone of the paratype- was found in the Bennett collection at MOL; it was prepared on September 13, 1994. This specimen does not have locality data; only an annotation that indicates that it is a "Plant of Edwards".

\section{Stenia jarae D.E.Benn., Lindleyana 7: 80. 1992.}

TYPE: Peru, Department of Huanuco, Province of Leoncio Prado, Bella, Cueva de Las Lechuzas, 900 m., [29 Dec 1990], E Jara sub Bennett 4711-3. Holotype: according to the protologue at USM, now deposited at MOL. Paratypes: Peru, Huanuco, Leoncio Prado, near Las Palmas, 1000 m, 20 Dec 1989. E. Jara sub Bennett 4711-1 Paratype: according to the protologue at USM, now deposited at MOL[-spirit]. Peru, [same collection data as E. Jara sub Bennett 4711-1], E. Jara sub Bennett 4711-2. Paratype: according to the protologue at USM, now deposited at MOL? [see below].

E Jara sub Bennett 4711-3 found in the Bennett collection at MOL has an annotation of Bennett that indicates that it is the holotype. The specimen was prepared on December 29, 1990.

Bennett 4711-2 (paratype?), in the Bennett collection at MOL, was collected at: 900 m of elevation, in "las alturas de Cayumba" (Leoncio Prado) and was prepared on October 10, 1990. On the label of this specimen David Bennett wrote: "sp. nov".

Stenia lillianae Jenny ex D.E.Benn. \& Christenson, Brittonia 46: 46. 1994.

TYPE: Peru, Dept. San Martin, Moyobamba, Pacaysapa, 1100 m, 4 Oct 1992, B. Collantes ex D. Bennett 5684. Holotype: NY!. PARATYPE: Peru, Dept. San Martin, Moyobamba, exact locality not given, 3 Sept 1992, R. Villena ex D. Bennett 5713 (according to the protologue at USM, now deposited at MOL[spirit]). 
Three specimens of Bennett 5684 with two different suffixes were found in the Bennett collection at MOL: Bennett 5684-1 in spirit and two pressed specimens of Bennett 5684-2 prepared on different dates: April 21, 1993 and April 14, 1994. Bennett 5684-2 was cited as the illustration voucher in the original publication (Fig. 14, page 47). Bennett 5713 in spirit; the paratype of S. lillianae, was found at MOL; however, a pressed preparation it was not found in any Peruvian herbarium

Stenia luerorum D.E.Benn. \& Christenson, Lindleyana 13: 91.1998.

TYPE: Peru, Pasco, Oxapampa, Chontabamba, 1600 m, leg. O. del Castillo, Jan 1994, flowered in cultivation 17 Apr 1994, Bennett 6534. Holotype: NY, lost; Isotypes: USM, lost. LECTOTYPE here designated: Peru, without locality data [probably same as in the protologue], Bennett 6534 (MOL-spirit; Fig. 63).

The holotype was not found at NY (T. Zanoni, pers. comm.) nor the isotype at USM. However, Bennett 6534 in spirit, consisting of a dissected flower that agrees with the illustration of the original publication, was found in the Bennett collection at MOL. The illustration was prepared on October 12, 1994; probably on the date when the specimen in spirit was prepared. As there is no holotype, a lectotype is designated here (ICN. Art. 9.2). The specimen chosen as lectotype is the specimen in spirit conserved at MOL (ICN. 9A.2).

Stenia pastorellii D.E.Benn., Lindleyana 7: 83. 1992.

TYPE: Peru, Department of San Martin, Province of Moyobamba, near Jepelacio, 950 m, 20 Dec 1989 [prepared on $25 \mathrm{Feb}$ 1991], R. Villena sub Bennett 4879. Holotype: according to the protologue at USM, now deposited at MOL.

The specimen has no locality data on the label, only the date of preparation (February 25, 1991) and an annotation that indicates that it is the holotype.

Stenia pustulosa D.E.Benn. \& Christenson, Brittonia 46: 48. 1994.

TYPE: Peru, Tarma, southeast of Contayapaccha, Quebrada Seca 1890 m, 22 April 1992, O. del Castillo ex D. Bennett 5552. Holotype: NY lost; [Isotype:
MOL-spirit, here designated as LECTOTYPE] (Fig. 64). PARATyPes: Peru, Same date and locality as holotype, O. del Castillo ex D. Bennett 5553. Paratype: USM, lost. Peru, Dept. Junin, Prov. Jauja, above Monobamba, Sector Cedrulla, $2300 \mathrm{~m}, O$. del Castillo ex D. Bennett 6311 [Bennett 6311-8 annotated on the label of the specimen]. Paratype: NY!.

The holotype was not found at NY (T. Zanoni, pers. comm.). The extant isotype (in spirit) found in the Bennett collection at MOL is here designated as lectotype (ICN. Art. 9.12). The specimen is a dissected flower that agrees with the illustration of the original publication.

Bennett 5553 (paratype) was not found in any Peruvian herbarium. However, Bennett 5553-3 in spirit was found in the Bennett collection at MOL.

Bennett 6311; which was designated as a paratype in the protologue, was not found at NY. However, Bennett 6311-8 (a clone) was found at NY where it is designated as paratype and was prepared on September 27, 1993. Two specimens of the Bennett 6311-4 (another clone of the paratype) in the Bennett collection at MOL were prepared on October 18, 1994 and November 27, 1995, respectively. However, they are not part of the original material because they were prepared after the species description.

Stenia wendiae D.E. Benn. \& Christenson, Brittonia 46: 51. 1994.

TYPE: Peru, Dept. Junin, Chanchamayo, sector Chipes of the San Vicente mine, 1800 m, 10 Dec 1992, O. del Castillo ex D.Bennett 5968. Holotype: NY, lost. Paratype: Same locality as the holotype, O. del Castillo ex D. Bennett 5967. Paratype: USM, lost, [MOL-spirit, wrong determination; see below]. LECTOTYPE here designated: Peru, without locality data [probably same as in the protologue], Bennett 5968-2 (MOL-spirit; Fig. 65).

The holotype was not found at NY (T. Zanoni, pers. comm.). However, Bennett 5968-2 in spirit (a clone of the holotype), consisting of a dissected flower that agrees with the illustration of the original publication, was found in the Bennett collection at MOL. It was cited as the illustration voucher in the protologue (Fig 17 , page 52); but not designated as the type.

Bennett 5967 in spirit found in the Bennett collection 
at MOL was originally published as Stenia jarae by Bennnett \& Christenson in 1993 (Icon. Orchid. Peruv.: t. 189); and it is clearly this species. However, a year later the same authors erroneously cited Bennett 5967 as a paratype of $S$. wendiae. Therefore, this specimen can not be considered a paratype of $S$. wendiae.

Because holotype is lost and as the specimen designated as "paratype" does not represent $S$. wendiae; the specimen here chosen as lectotype is Bennett 5968-2; that was cited as the illustration voucher in the original publication (ICN. 9A.2).

Stigmatorthos peruviana M.W.Chase \& D.E.Benn., Lindleyana 8: 7. 1993.

TYPE: Peru, Pasco, Oxapampa, Aguachini, 26 km S.SE of Puerto Bermudez, above Rio Azupizu, 700 m, 20 Oct 1990, O. del Castillo sub D. Bennett 4748. Holotype: SEL, lost. [Isotype: MOL-spirit here designated as LectotyPE] (Fig. 66).

The holotype was not found at SEL (B. Holst, pers. comm.).The extant isotype (in spirit) found in the Bennett collection at MOL, consisting of flowers (some dissected) that agree with the illustration of the original publication, is here designated as lectotype (ICN. Art. 9.12).

Telipogon alegriae D.E.Benn. \& Christenson, Icon. Orchid. Peruv.: t. 779. 2001.

TYPE: Peru, Huancavelica, Tayacaja, Huachocolpa district, 3400 m, 25 Jun 1999, M. León M. et al. 3024, as Bennett 7934. Holotype: originally deposited at Herb. Bennettianum, now at MOL, [SyntyPES, see below]. LестотуPE here designated: Peru, without locality [but same as the original publication], $M$. León M. et al. 3024 (MOL-spirit, Fig. 67; Isolectotype: MOL).

Two specimens of M. León $M$ et al. 3024 were found in the Bennett collection at MOL: one pressed and one in spirit. Both specimens consist of a complete plant with flower. The pressed specimen was kept by Bennett unmounted and without label. Neither of the specimens has an annotation that indicates that it is the holotype or that they constitute a single specimen. Therefore both specimens found in the Bennett collection represent syntypes (ICN. Art. 40 Note 1).
As there is no holotype, a lectotype is designated here (ICN. Art. 9.2). The specimen chosen here as lectotype is the specimen in spirit that has a flower dissected.

Telipogon antonietae D.E.Benn. \& Ric.Fernández, Publ. Mus. Hist. Nat. Univ. Nacion. Mayor San Marcos, Bot. 36: 2. 1992.

TYPE: Peru, Junin, Satipo, along the road to Huancayo above Satipo, 2500 m, 31 June 1987, D. Bennett, Jr., A. de Bennett, G.G. Bennett B. \& A. Vargas P. 3905. Holotype: according to the protologue at USM, now deposited at MOL-spirit (Fig. 68).

Bennett et al. 3905 in spirit was found in the Bennett collection at MOL; however, a pressed preparation was not located in any Peruvian herbarium. The spirit specimen, consisting of four flowers (two dissected) that agree with the description and illustration of the original publication is the holotype.

Telipogon ariasii Dodson \& D.E.Benn., Icon. Pl. Trop., II, 2: t. 184. 1989.

TYPE: Peru, Junin, Tarma, Huasahuasi, 2800 m, 7 Jun 1986, Bennett 3613. Holotype: MO, not found. Leстотуре here designated: Peru, Junin, Tarma, Huasahuasi, 2850 m, 29 Aug 1987, Bennett 3613 (MOL).

The holotype was not found at MO. Two pressed specimens of Bennett 3613 were found at NY and MOL, but their dates of preparation disagree with that given in the protologue. The specimen at NY was prepared on June 9, 1986 and the specimen at MOL on August 29, 1987. As there is no holotype, a lectotype is designated here (ICN. Art. 9.2). The specimen here chosen as lectotype is the most complete specimen conserved at MOL.

Telipogon atropurpurea D.E.Benn. \& Ric.Fernández, Publ. Mus. Hist. Nat. Univ. Nacion. Mayor San Marcos, Bot. 36: 9. 1992.

TYPE: Peru, Piura, Huancabamba, near Laguna Huaringas, $3000 \mathrm{~m}$, collector J. Campoverde, plant loaned by I. Rolando, 2 Sept 1989, [7 Sept 1989, in error], Bennett 4562. Holotype: according to the protologue at USM, now deposited at MOL. 


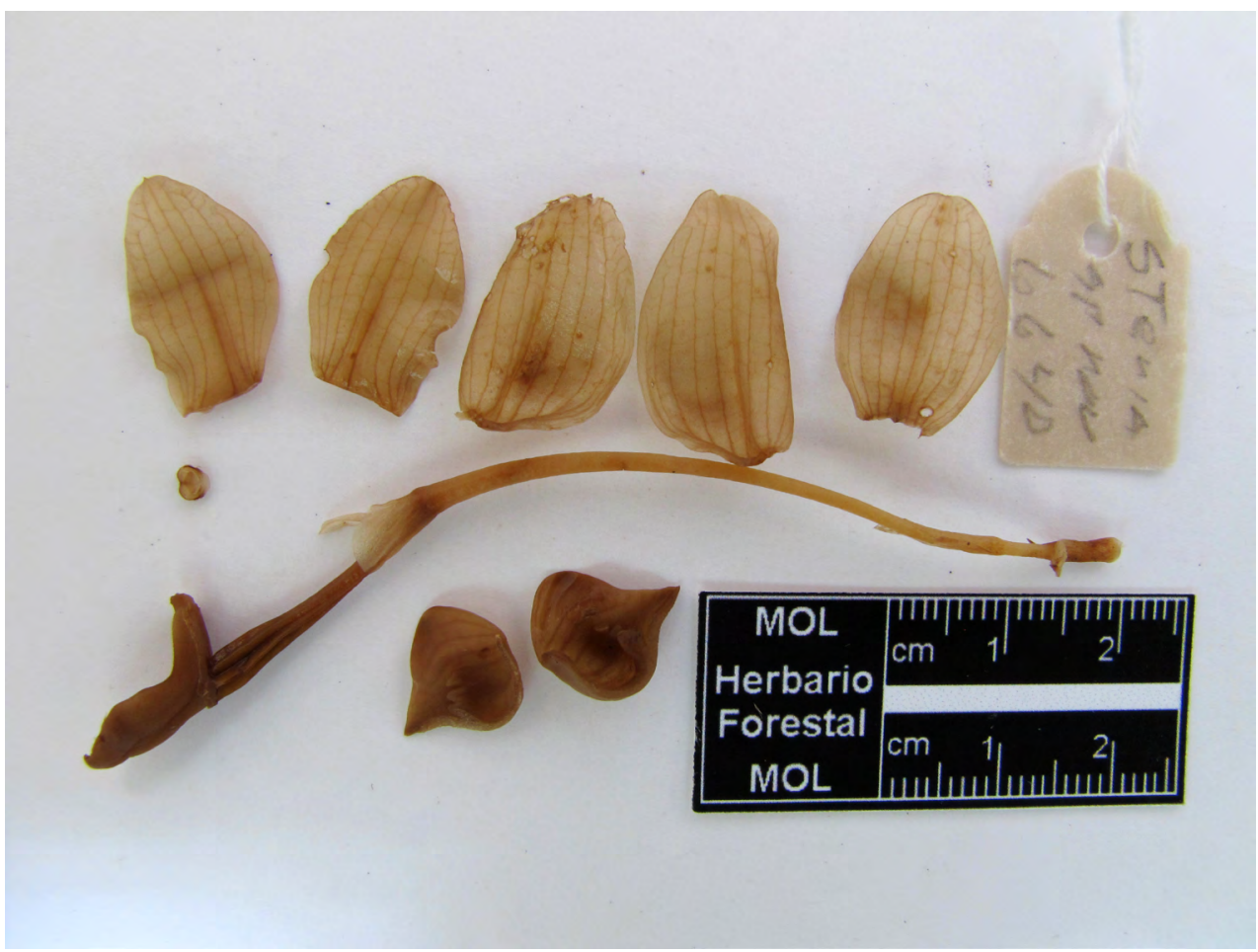

FiguRE 61. Stenia aurorae D.E.Benn. \& Christenson. Lectotype at MOL (Bennett 6640 in spirit). Photo: D. Trujillo.

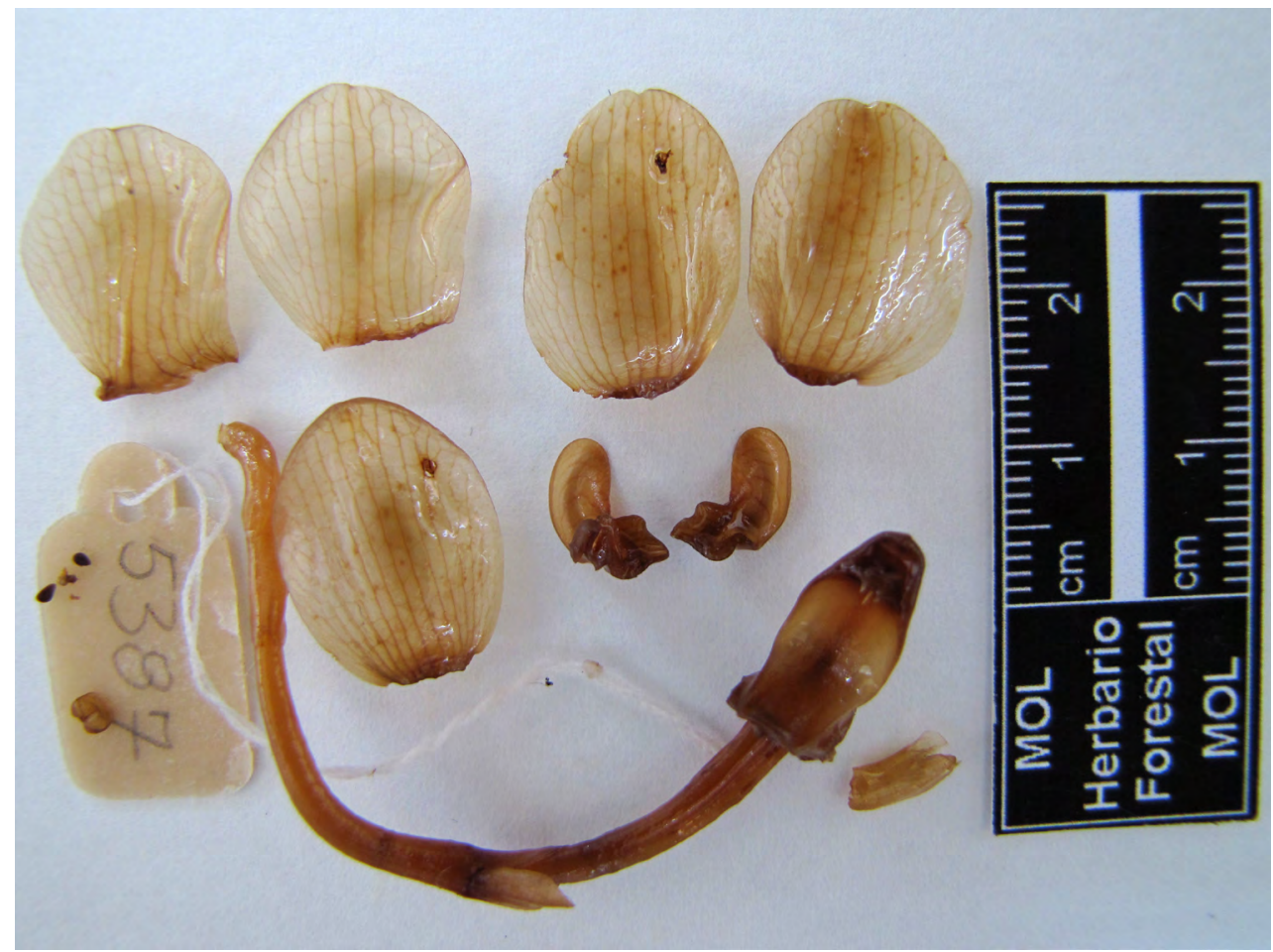

FIgURE 62. Stenia christensonii D.E. Benn. Lectotype at MOL (Bennett 5387 in spirit). Photo: D. Trujillo. 


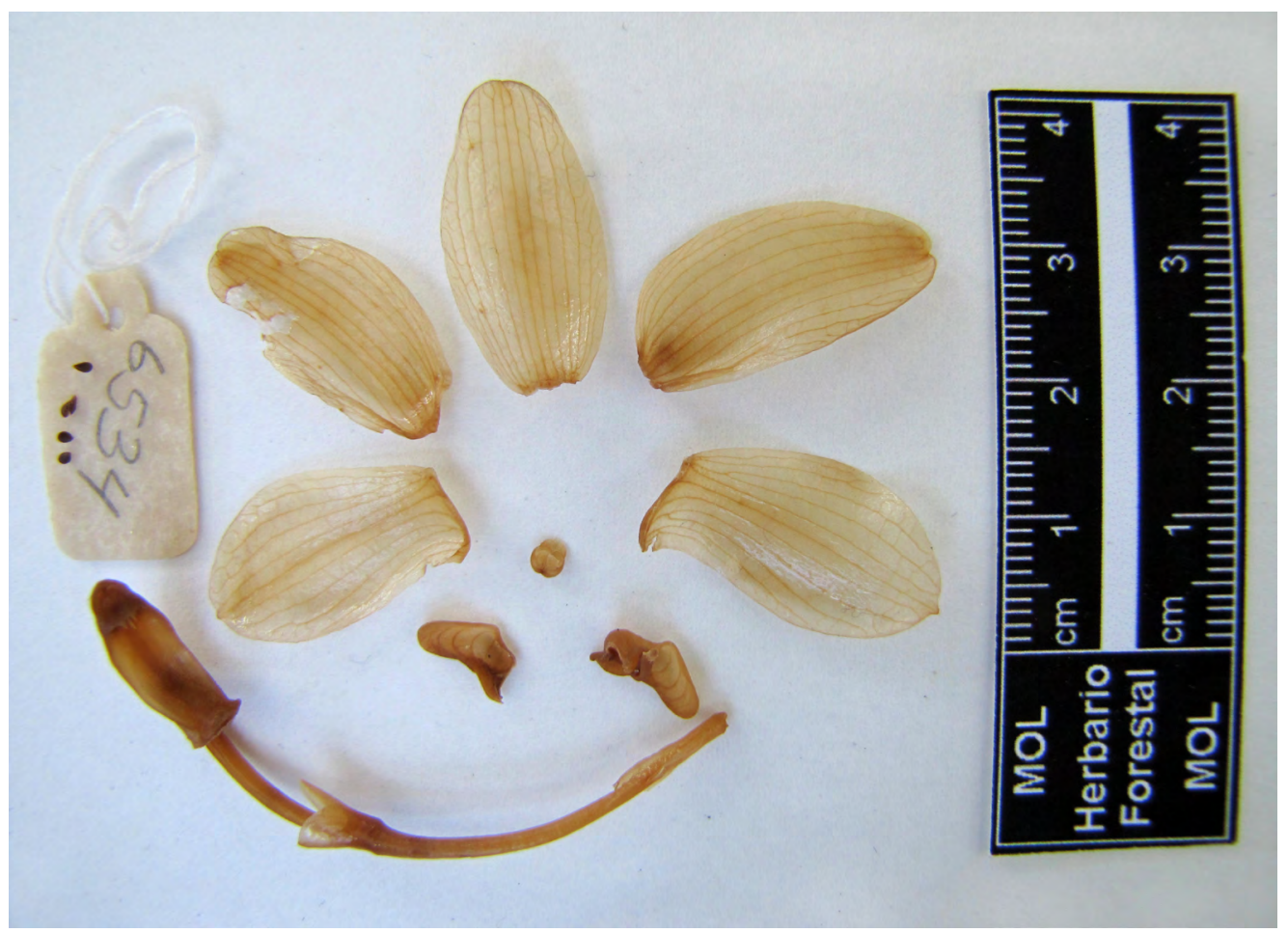

Figure 63. Stenia luerorum D.E.Benn. \& Christenson. Lectotype at MOL (Bennett 6534 in spirit). Photo: D. Trujillo.

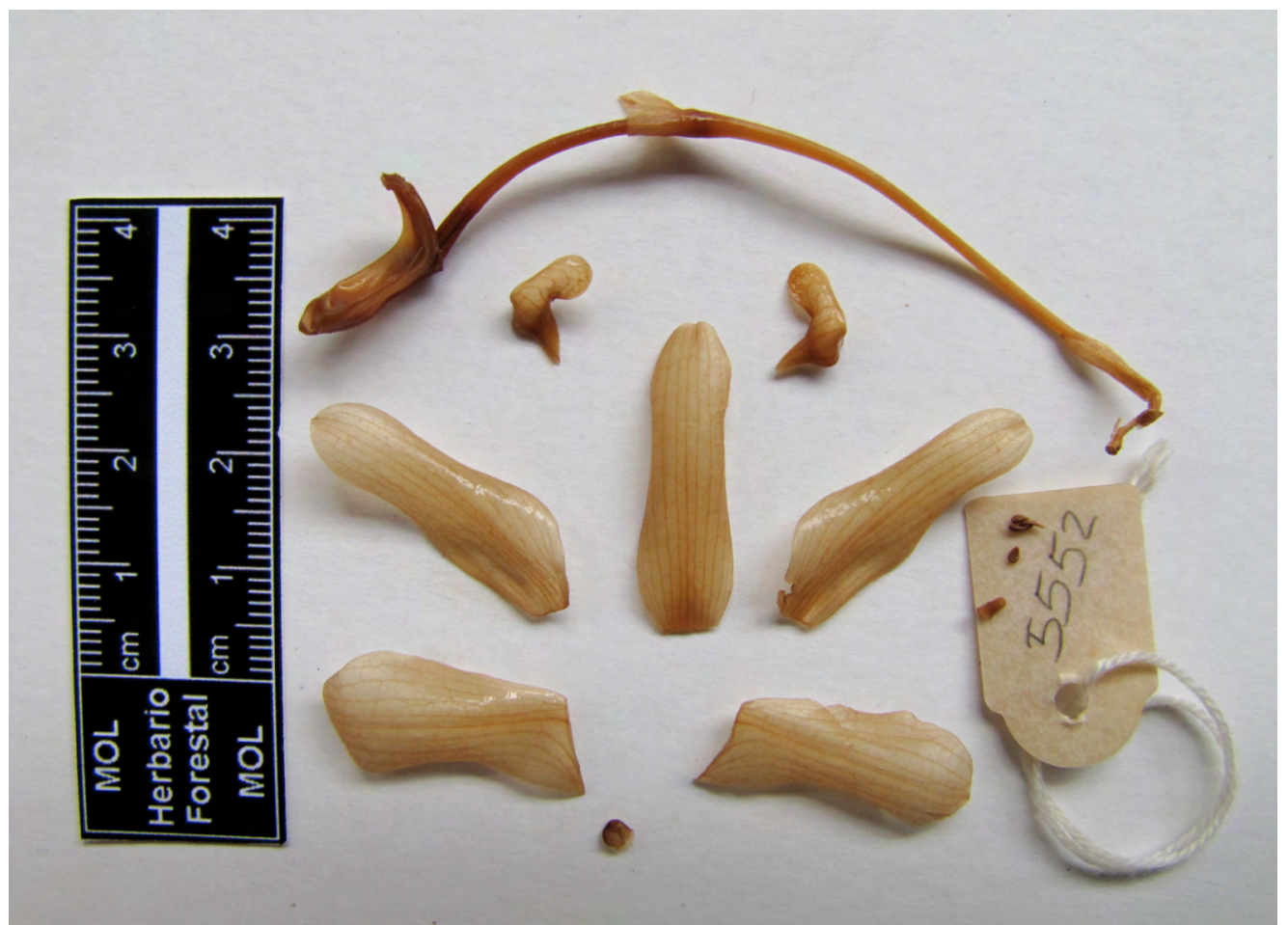

Figure 64. Stenia pustulosa D.E.Benn. \& Christenson. Lectotype at MOL (D. Bennett 5552 in spirit). Photo: D. Trujillo. LANKESTERIANA 14(1), April 2014. (C) Universidad de Costa Rica, 2014. 




Figure 65. Stenia wendiae D.E. Benn. \& Christenson. Lectotype at MOL (Bennett 5968-2 in spirit). Photo: D. Trujillo.

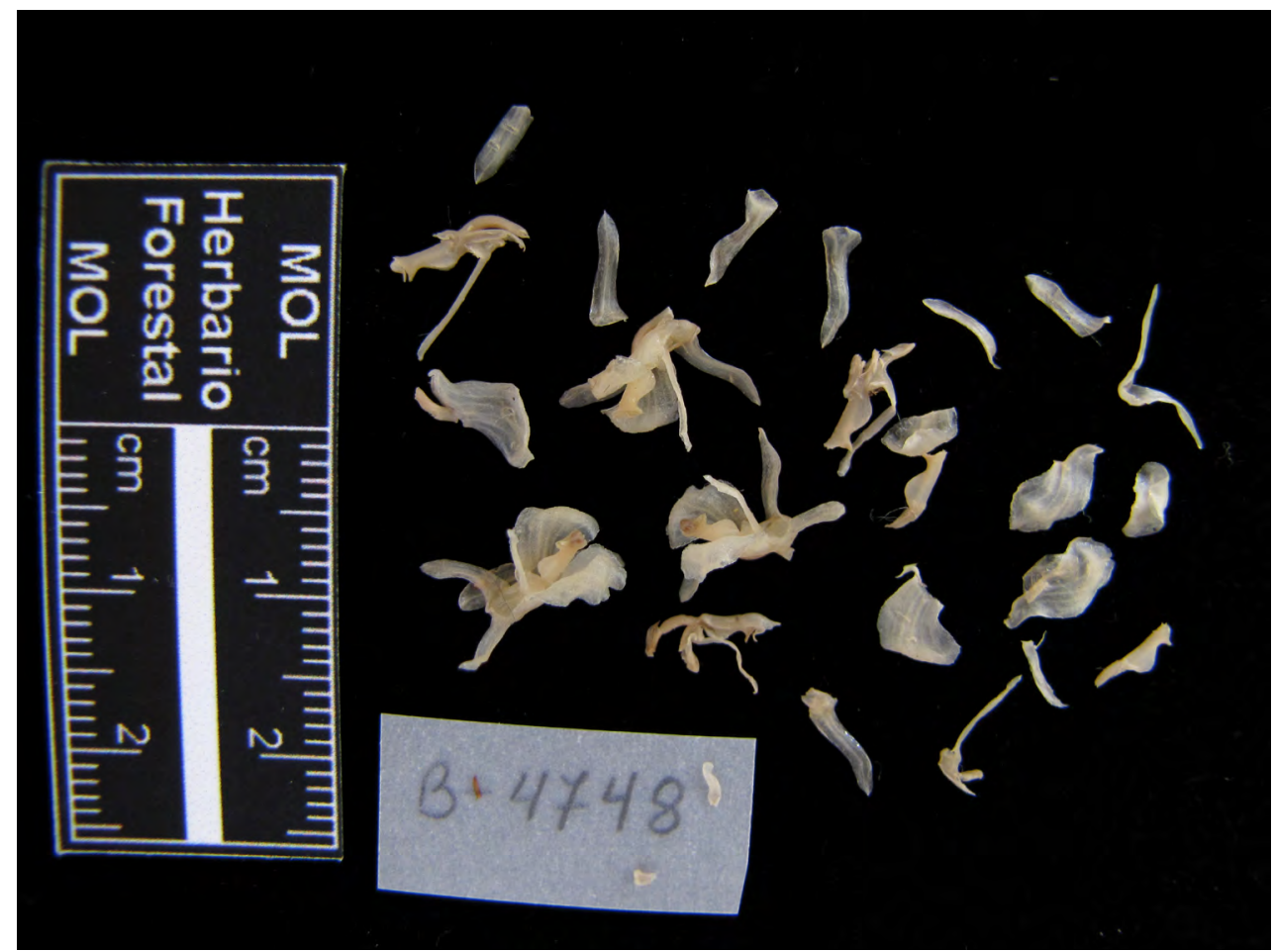

Figure 66. Stigmatorthos peruviana M.W.Chase \& D.E.Benn. Lectotype at MOL (Bennett 4748 in spirit). Photo: D. Trujillo. 


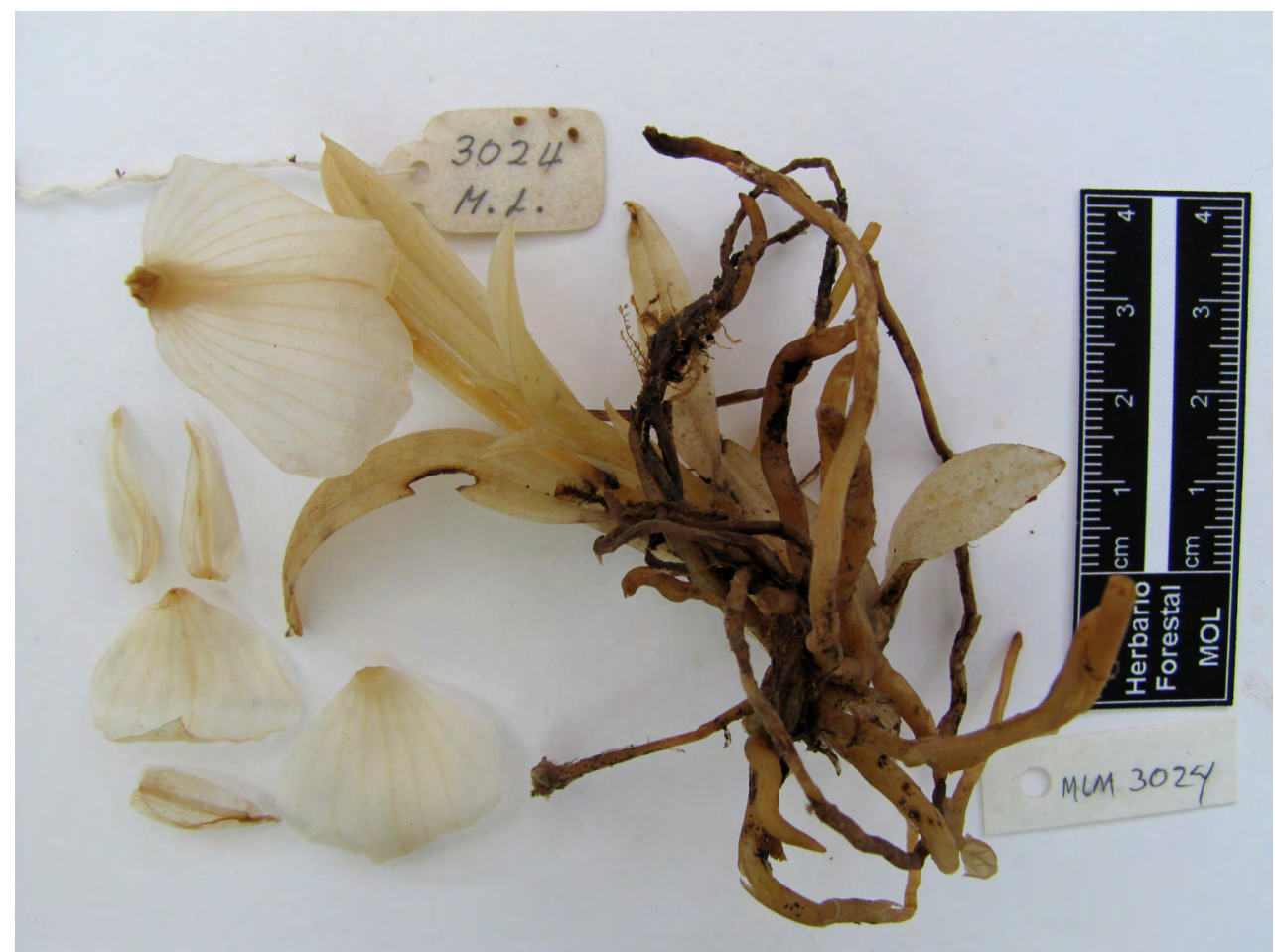

FiguRE 67. Telipogon alegriae D.E.Benn. \& Christenson. Lectotype at MOL (M. León M. 3024 in spirit). Photo: D. Trujillo.

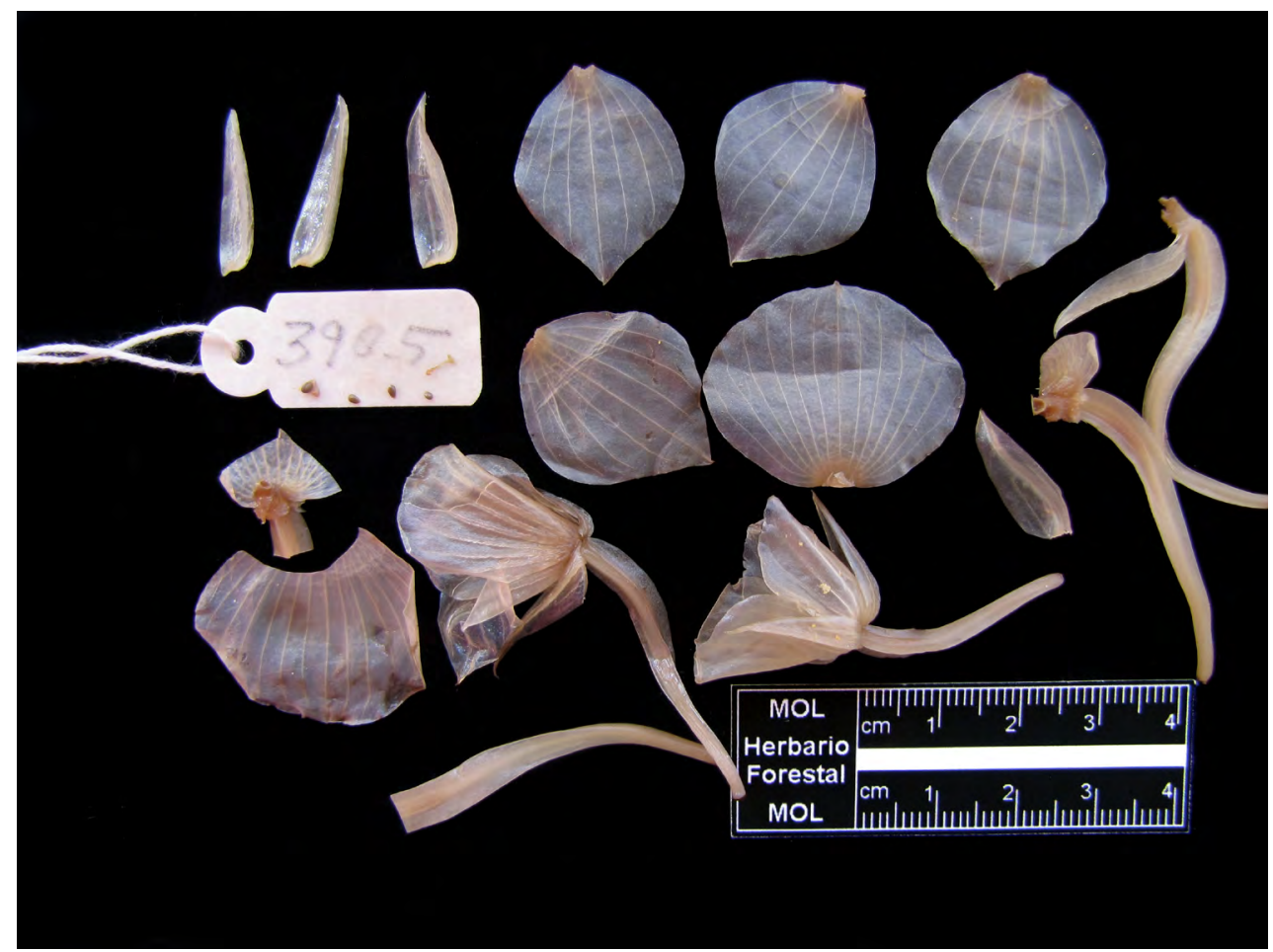

FiguRe 68. Telipogon antonietae D.E.Benn. \& Ric.Fernández. Holotype at MOL (Bennett 3905 in spirit). Photo: D. Trujillo. LANKESTERIANA 14(1), April 2014. (C) Universidad de Costa Rica, 2014 
The specimen was prepared and illustrated on September 2, 1989.

Telipogon auriculatus D.E.Benn. \& Christenson, Icon. Orchid. Peruv.: t. 780. 2001.

TYPE: Peru, Junin, Chanchamayo, San Ramon district, La Promisora, ca. 1600 m, 19 Apr 1996 [prepared on 6 May 1996], O. del Castillo [Isabel Espinoza G, in error] ex Bennett 7496 . Holotype: originally deposited at Herb. Bennettianum, now at MOL; [Isotype: MOLspirit.]

Two preparations of Bennett 7496 were found in the Bennett collection at MOL: one pressed and the other in spirit. Bennett wrote on the label of the pressed specimen: "sp. nov" but did not indicate that the flower in spirit was part of the same specimen. Therefore the specimen in spirit is an isotype (ICN. Art. 8.3).

The data written on the label indicates that the specimen was collected by $\mathrm{O}$. del Castillo and not by Isabel Espinoza F. and was prepared on May 6, 1996. Therefore the original type citation in the protologue is erroneous and here is corrected.

Telipogon campoverdei D.E.Benn. \& Ric.Fernández, Publ. Mus. Hist. Nat. Univ. Nacion. Mayor San Marcos, Bot. 36: 6. 1992.

TYPE: Peru, Piura, Huancabamba, near Laguna Huaringas, 3000 m, 6 September 1989, cultivated by I. Rolando, collector J. Campoverde sn. in Bennett 4561. Holotype: according to the protologue at USM, now deposited at MOL.

Telipogon collantesii D.E. Benn. \& Christenson, Icon. Orchid. Peruv.: t. 782. 2001.

TYPE: Peru, Huancavelica, Tayacaja, Huachocolpa district, Pureqyaco, 3000 m, 15 Jun 1999, M. León et al. 3068. Holotype: originally deposited at Herb. Bennettianum, now at MOL [SyNTYPES, see below]; Isotype: NY [not here], LестотуPE here designated: Peru, Huancavelica, Tayacaja, Huachocolpa district, Pureqyacu, 3000 m, coll. on 15 Jun 1999, prepared on 28 Jun 1999, M. León et al. 3068 (MOL-spirit, Fig. S69; Isolectotype: MOL).

The report of M. León et al. indicates that only living specimens of M. León et al. 3068 were collected (on June 14-16, 1999). But the specimens (as well the illustration) were prepared on June 28, 1999. Therefore Bennett neglected to cite in the protologue when the specimens were prepared.

Two preparations of M. León 3068 are in the Bennett collection at MOL: one pressed and the other in spirit. However, neither has an annotation that indicates that it is the holotype, or that they constitute a single specimen (as required by ICN. Art. 8.3). Therefore both specimens found in the Bennett collection represent syntypes (ICN. Art. 40 Note 1). As there is no holotype, a lectotype is designated here (ICN. Art. 9.2). The specimen here chosen as lectotype is the most complete specimen (in spirit).

The correct locality and elevation data are cited in the protologue; which are the same that indicates the field report of M. León et al.. On the label of the pressed specimen (MOL) Bennett wrote different locality and elevation data: "Huachocolpa. Inquilpata and $2800 \mathrm{~m}$ ", these are erroneous.

Bennett wrote on the label of the spirit specimen:"= 3072" (see Fig. 69); this annotation indicates that the specimen M. León 3072 is the same species as M. León 3068 .

Telipogon davidsonii D.E. Benn. \& Christenson, Icon. Orchid. Peruv.: t. 783. 2001.

TYPE: Peru, Piura, Huancabamba, 2-3 km from the road at Cruz Blanca, 3150 m, 22 Sept 1993, J. Campoverde ex Bennett 6443. Holotype: NY, lost. Lectotype here designated: Peru, Piura, Huancabamba, $15 \mathrm{~km} \mathrm{NE}$ of Huancabamba, 3100 m, 23 Sept 1993, J. Campoverde, D.E. Bennett 6438 [not 6433] (NY; Isolectotype: MOL-spirit).

Bennett 6443 designated as holotype in the protologue was not found at NY. However, another NY specimen, Bennett 6438, has been designated as holotype of Telipogon davidsonii (by Bennett?) but its collection data disagree with that given in the protologue. Two flowers (one dissected) of Bennett 6438 (in a single jar) were also found in the Bennett collection at MOL. The dissected flower agrees with the illustration of the original publication. Although Bennett 6438 was not cited in the protologue (neither in the Table Records of the illustrated Bennett's specimens), this specimen is part of the original 
material (ICN. Art. 9.3). As there is no extant holotype, a lectotype is designated here (ICN. Art. 9.2). The specimen here chosen as lectotype is the pressed specimen deposited at NY.

Telipogon genegeorgei D.E. Benn. \& Ric.Fernández, Publ. Mus. Hist. Nat. Univ. Nacion. Mayor San Marcos, Bot. 36: 4. 1992.

TYPE: Peru, Junin, Satipo, above Calabaza near Rio Pamapa Hermosa, 2550 m, 31 July 1987, D. Bennett, A. de Bennett, G.G. Bennett B. \& A. Vargas P. 3966. Holotype: according to the protologue at USM, now deposited at MOL. Paratype: Peru, Junin: Satipo, along the Satipo-Huancayo road, $2580 \mathrm{~m}, 2$ Aug 1987 [1 Aug 1987, in error], D. Bennett et al. 4014 (according to the protologue at USM, now deposited at MOL, MOL-spirit [x2]).

Telipogon sayakoae D.E.Benn. \& Christenson, Arnaldoa 6: 61.1999 (publ. 2000).

TYPE: Peru, Dpto. Pasco, Prov. Oxapampa; 2500 m, 27 mayo 1999, Hort, INRENA 008, L. Cristobal E. ex Bennett 7917. Holotype: originally deposited at Herb. Bennettianum, now at MOL[-spirit] (Fig. 70).

Bennett 7917 in spirit was found in the Bennett collection at MOL; however, as pressed preparation was not located. The spirit specimen, consisting of two flowers (one dissected) that agree with the illustration of the original publication is the holotype.

Telipogon suarezii D.E.Benn. \& Christenson, Icon. Orchid. Peruv.: t. 787. 2001.

TYPE: Peru, Huancavelica, Tayacaja, district of Huachcolpa, 3200 m, 29 July 1999, R. Suarez G., G. Alegria T. \& B. Collantes M. ex Bennett 7937. Holotype: originally deposited at Herb. Bennettianum, now at MOL; Isotype: NY, lost [MOL-spirit].

Two preparations of Bennett 7937 were found in the Bennett collection at MOL: one in spirit and one pressed specimen prepared on August 12, 1999. Bennett wrote on the label of the pressed specimen: "sp. nov" but did not indicate that the flower in spirit was part of the same specimen. Therefore the specimen in spirit is an isotype (ICN. Art. 8.3).
Telipogon tayacajaensis D.E.Benn. \& Christenson, Icon. Orchid. Peruv.: t. 788. 2001.

TYPE: Peru, Huancavelica, Tayacaja, 3200 m, 25 Aug 1999, León et al. 3053. Holotype: Herb. Bennettianum [now at MOL], lost, [Isotypes: USM (2153336) designated here as LectotyPE; Isolectotype: USM (215337)].

The field work report of M. León et al. indicates that specimens in spirit, pressed and living plant(s) of M. León et al. 3053 were collected on June 14-16, 1999. Five specimens of M. León et al. 3053 were found in the Bennett collection at MOL: one in spirit (two intact flowers) and four pressed. One pressed specimen was prepared by Bennett on June 22, 1999 [1994, in error] and was labeled Bennett 7922. The other three were un-mounted and lacked labels; they were probably prepared on June 14-16, 1999 by M. León. None of the specimens at the Bennett collection was prepared on the date cited in the protologue or has an annotation that indicated that it is the holotype.

Two additional specimens of M. León M et al. 3053 were found at USM. The collection data and dates of preparation of these specimens agree with that given in the protologue; therefore they are isotypes. As there is no holotype, a lectotype is designated here (ICN. Art. 9.2). The specimen at USM with the Accession Number "2153336" is here chosen as lectotype (ICN. Art. 9.12).

Trichoceros dombeyi D.E.Benn. \& Christenson, Icon. Orchid. Peruv.: t. 789. 2001.

TYPE: Peru, Piura, Huancabamba, $12 \mathrm{kms}$ above Huancabamba along road to Piura, 2600 m, 1964, P.C. Hutchison 6628 (as 64-688). Holotype: UC?. Paratype: Peru, Ancash, Huari, $15 \mathrm{~km} \mathrm{~N}$ of Huari, 7 Aug 1987, 3200 m, D. Bennett \& A. Bennett 3778 (originally deposited at Herb. Bennettianum, now at MOL?).

The specimen (paratype?) found in the Bennett collection at MOL has a different collector and date of preparation: Manuel Arias ex Bennett 3778 and December 14, 1986.

Trichoceros hajekiorum D.E.Benn. \& Christenson, Icon. Orchid. Peruv.: t. 790. 2001.

TYPE: Peru, Lima, Cajatambo, Huancahuasi, 3200 m, 


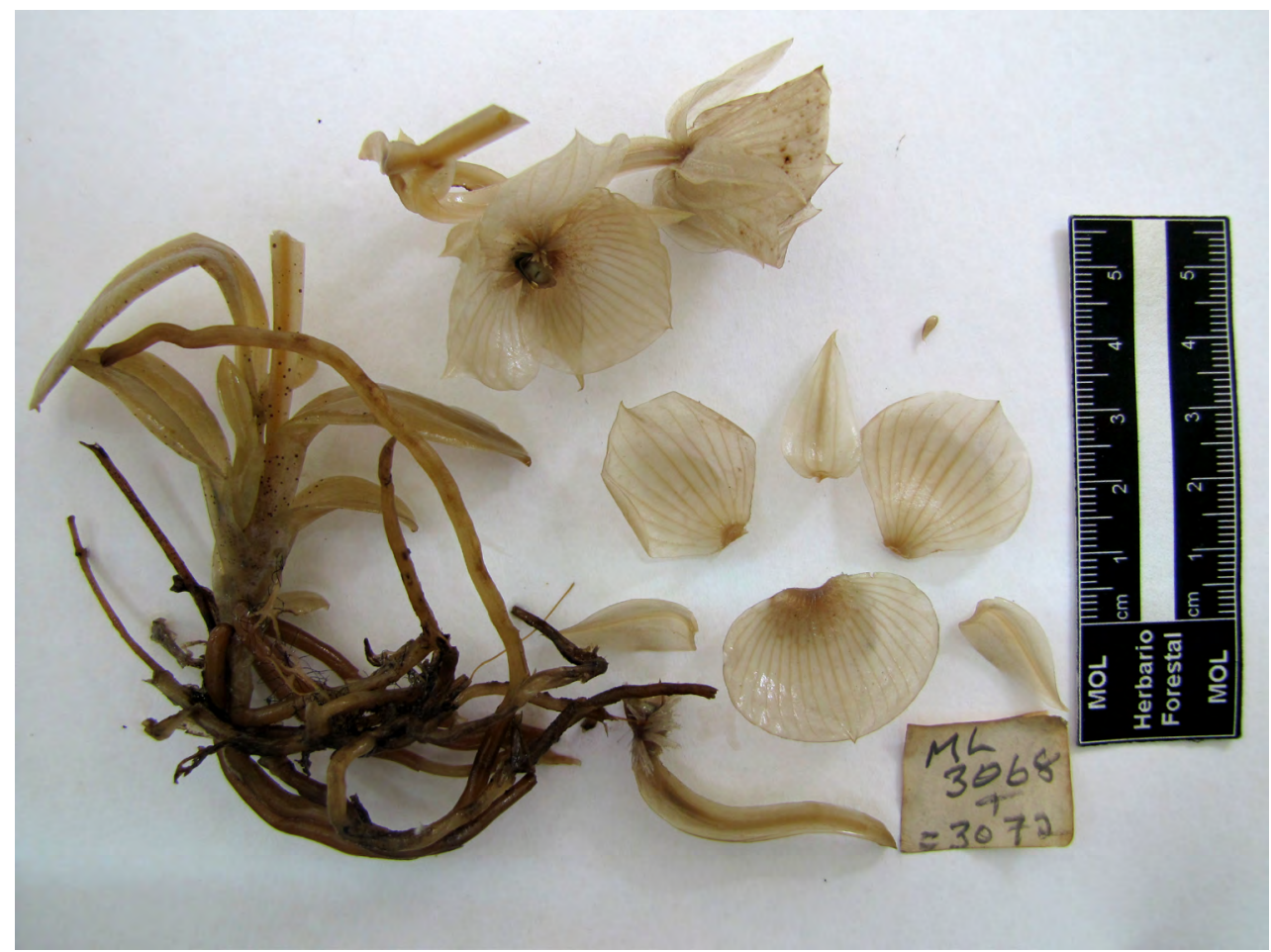

FIgURE 69. Telipogon collantesii D.E. Benn. \& Christenson. Lectotype at MOL (M. León 3068 in spirit). Photo: D. Trujillo.

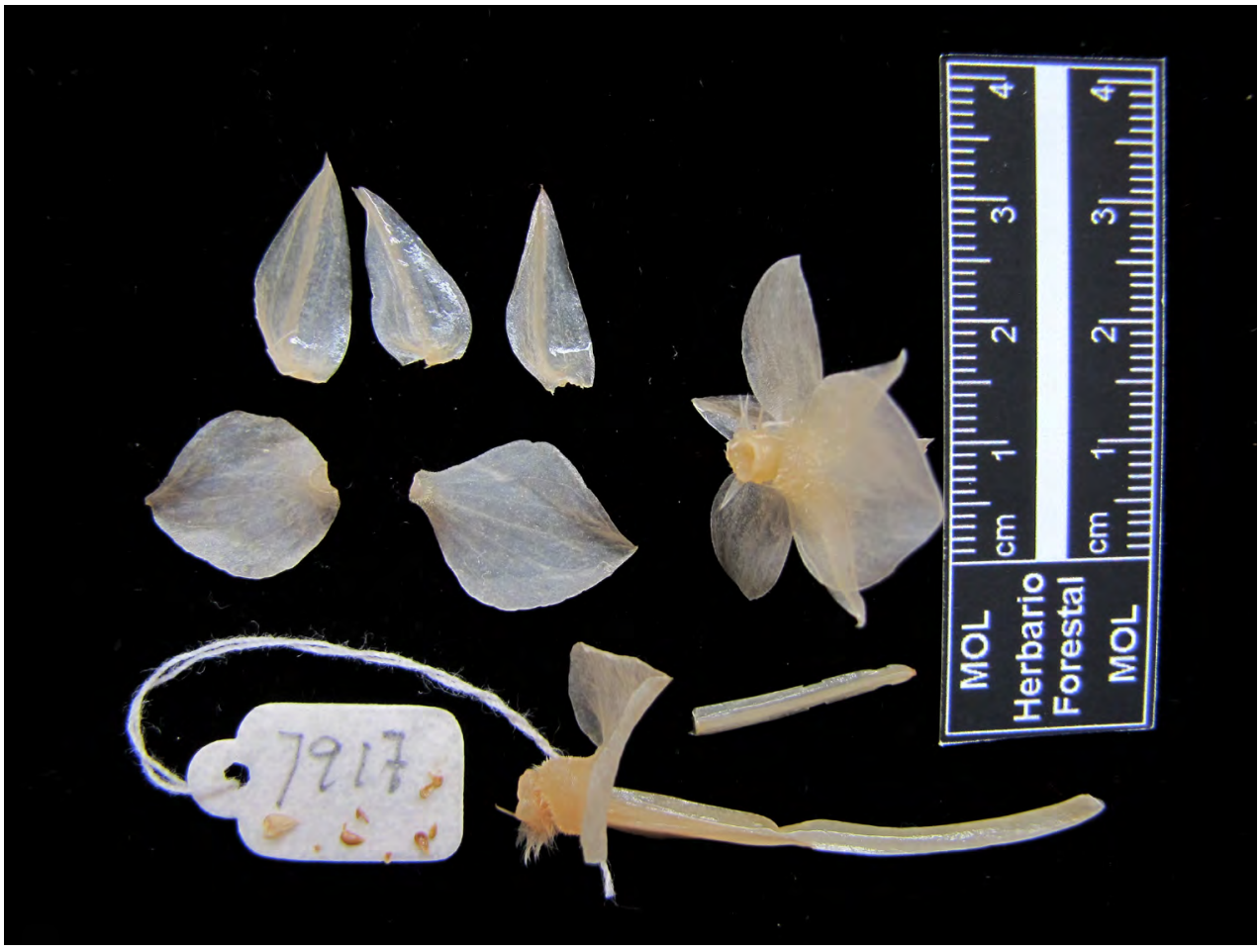

Figure 70. Telipogon sayakoae D.E.Benn. \& Christenson. Holotype at MOL (Bennett 7917 in spirit). Photo: D. Trujillo. 


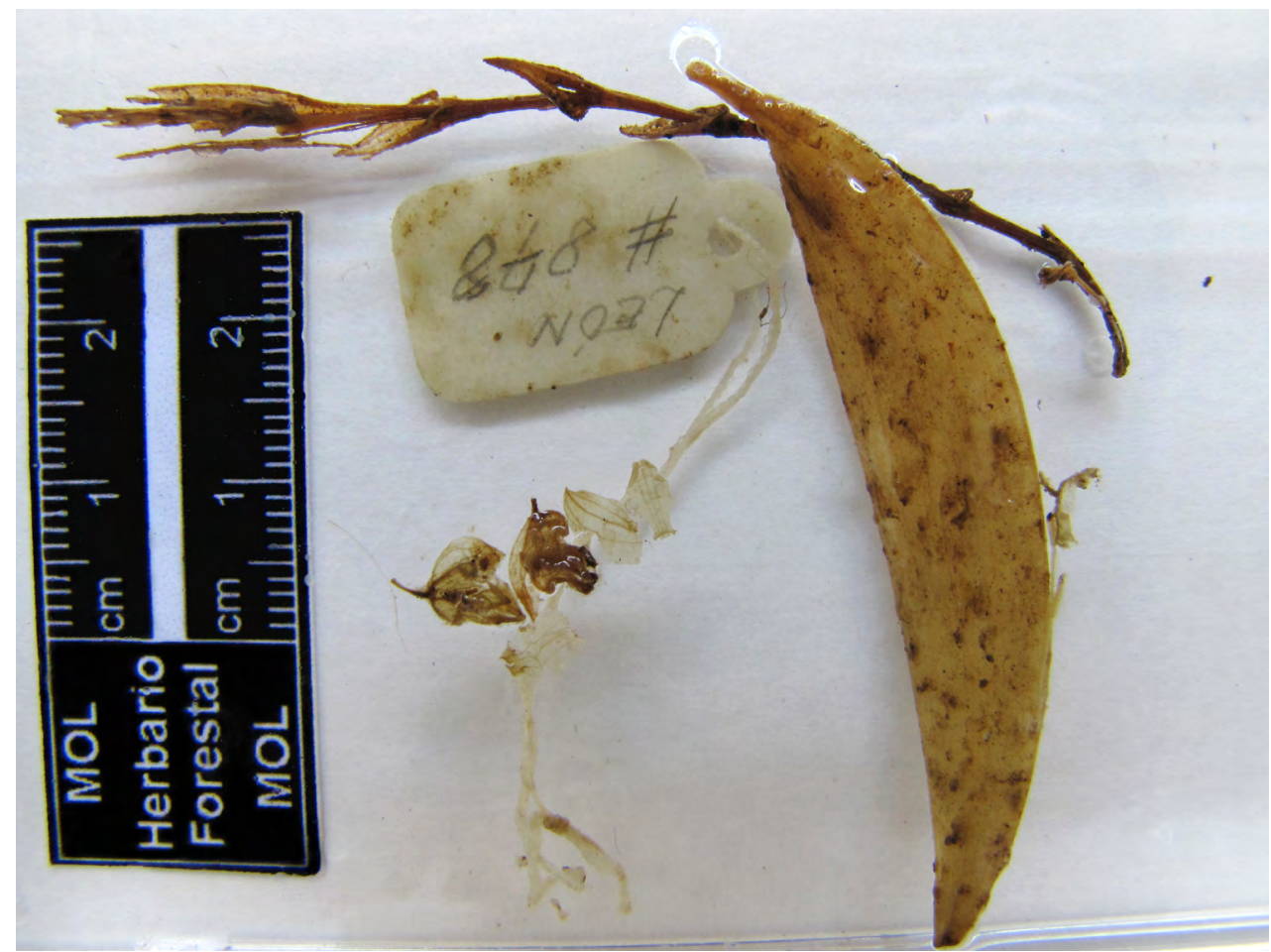

FiguRE 71. Trichosalpinx pandurata D.E. Benn. \& Christenson. Lectotype at MOL (M. León M. 878 in spirit). Photo: D. Trujillo.

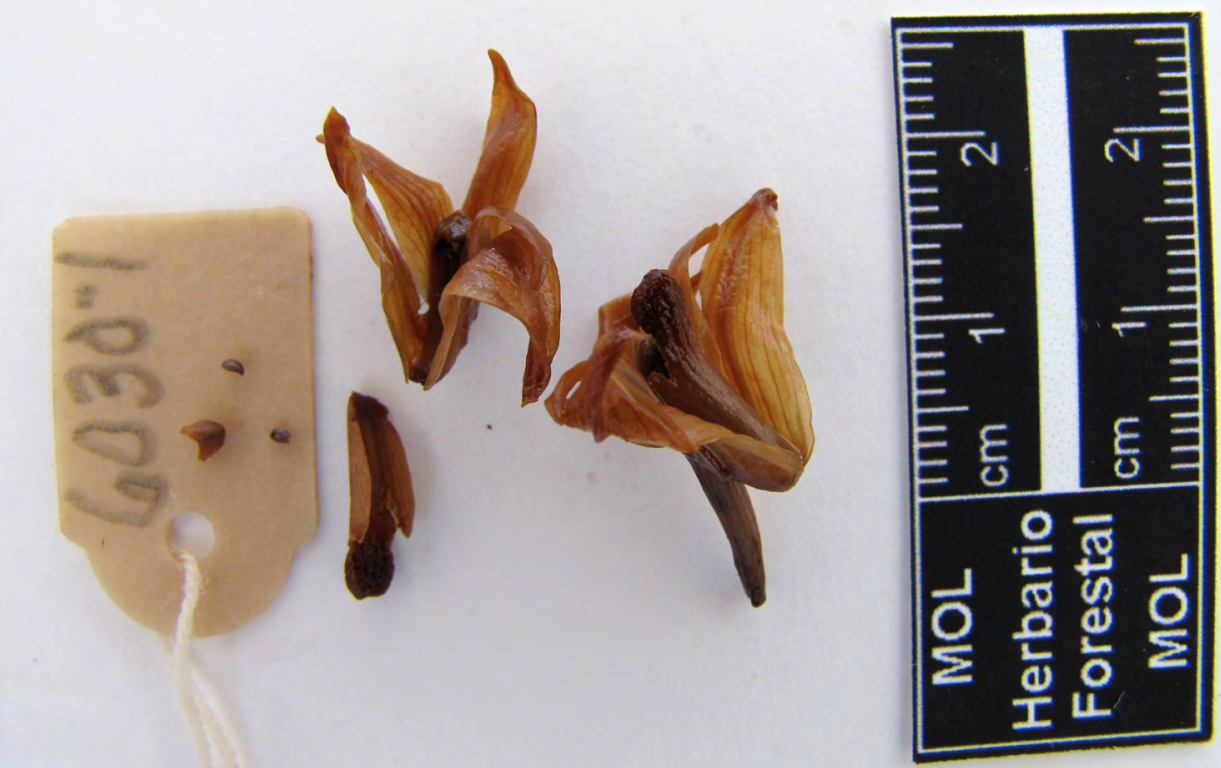

Figure 72. Xylobium serratum D.E.Benn. \& Christenson. Lectotype at MOL (Bennett 6030-1 in spirit). Photo: D. Trujillo. LANKESTERIANA 14(1), April 2014. (C) Universidad de Costa Rica, 2014. 
12 May 2000 [prepared on 15 May 2000], C. Hajek \& F. Hajek ex Bennett 7958. Holotype: originally deposited at Herb. Bennettianum, now at MOL, part in spirit.

The specimen found in the Bennett collection at MOL was prepared on May 15, 2000 and it has an annotation of Bennett that indicates that it is the holotype

Trichopilia undulatissima D.E.Benn. \& Christenson, Lindleyana 13: 95. 1998.

TYPE: Peru, Pasco, Oxapampa, near the town of Progreso towards San Isidro, $1770 \mathrm{~m}$, leg. O. del Castillo, Apr 1992, flowered in cultivation 23 Sept 1994, Bennett 5527. Holotype: NY!; Isotype: USM, lost; [MOL-spirit].

Trichosalpinx dentialae D.E.Benn. \& Christenson, Icon. Orchid. Peruv.: t. 792. 2001.

TYPE: Peru, Cajamarca, San Ignacio, Tabaconas District, Linderos sector along Rio Tabaconas, $1450 \mathrm{~m}$, 20 Jun 1996 [prepared on 7 Nov 1996], O. del Castillo ex Bennett 7630. Holotype: originally deposited at Herb. Bennettianum, now at MOL.

The specimen was prepared on November 7, 1996.

Trichosalpinx pandurata D.E. Benn. \& Christenson, Icon. Orchid. Peruv.: t. 793. 2001.

TYPE: Peru, Junin, Chanchamayo, La Promisoria, 1250 m, M. León M. \& B. Collantes M. 878 ex Bennett 7657. Holotype: MOL; Isotype: originally deposited at Herb. Bennettianum, now at MOL-spirit. [SYNTYPeS, see below]. Lectotype here designated: Peru, without locality data [probably same as in the protologue], M. León M. \& B. Collantes M. 878 [ex Bennett 7657] (MOL-spirit; Fig. 71).

Two preparations of M. León 878 are in the Bennett collection at MOL: one pressed and the other in spirit. However, neither is annotated to indicate which is the holotype or that they represent a single specimen (as required by ICN. Art. 8.3). Therefore they represent syntypes (ICN. Art. 40 Note 1). In absence of holotype, the specimen in spirit is chosen and designated here as lectotype (ICN. Art. 9.2).

Xylobium serratum D.E.Benn. \& Christensona, Icon. Orchid. Peruv.: t. 799. 2001.

TYPE: Peru, Pasco, Oxapampa, $8 \mathrm{kms}$ north of Villarica, 1525 m, Aug 1993, J. Campoverde ex Bennett 6030. Holotype: originally deposited at Herb. Bennettianum, [now at MOL], lost. Lectotype here designated: Peru, without locality data [probably same as in the protologue], Bennett 6030-1 (MOLspirit; Fig. 72).

The holotype was not found. However, Bennett 6030-1 in spirit (a clone of the holotype), consisting of two intact flowers was found in the Bennett collection at MOL. The Table Records of the illustrated Bennett's specimens indicates that the illustration of Xylobium serratum was prepared based on Bennett 6030-1. As not cited specimen exists, the uncited specimen (Bennett 6030-1) is here chosen as the lectotype (ICN. Art. 9.12).

Zootrophion leonii D.E.Benn. \& Christenson, Icon. Orchid. Peruv.: t. 800. 2001.

TYPE: Peru, Huancavelica, Tajacaya, District of Huachocolpa, above Lucuma, 2300 m, 19 Feb 1999 [prepared on 17 April 1999], M. León M. et al. 3019 ex Bennett 7878. Holotype: originally deposited at Herb. Bennettianum, now at MOL.

A pressed specimen Zootrophion; label as $M$. León M. et al. 3018 ex Bennett 7878, was found in the Bennett collection at MOL This specimen was wrongly labeled as "MLM 3018". The correct collection number is " 3019 "; which is the number that indicates the field work report of M. León and the protologue. The report of M. León et al. also indicates that they only collected living plant(s).

The specimen (holotype) was prepared on April 17, 1999.

\section{VALIDATION OF NEW COMBINATIONS}

Cyrtochilum miradorense (D.E.Benn. \& Christenson) Dalström ex D. Trujillo., comb. nov.

Basionym: Oncidium miradorense D.E. Benn. \& Christenson, Lindleyana 13: 80. 1998.
The combination Cyrtochilum miradorense was invalidly proposed by Dalström (2002) because he did not provide the complete basionym reference (contrary to ICBN, Art 33.3). The combination is validated here. 
TABLE 1. List of lectotypes and isolectotypes designated in the manuscript indicating the repository herbarium and the type of specimen preparation.

\begin{tabular}{|c|c|c|c|c|}
\hline \multirow[b]{2}{*}{ Species } & \multicolumn{2}{|c|}{ Lectotype } & \multicolumn{2}{|c|}{ Isolectotype } \\
\hline & $\begin{array}{l}\text { Repository } \\
\text { Herbaria }\end{array}$ & $\begin{array}{c}\text { Type of } \\
\text { Specimen } \\
\text { Preparation }\end{array}$ & $\begin{array}{l}\text { Repository } \\
\text { Herbaria }\end{array}$ & $\begin{array}{c}\text { Type of } \\
\text { Specimen } \\
\text { Preparation }\end{array}$ \\
\hline Ada rolandoi D.E. Benn. \& Christenson & MOL & Pressed & & \\
\hline Brassia aurorae D.E.Benn. & USM & Pressed & & \\
\hline Brassia pascoensis D.E.Benn. \& Christenson & MOL & Pressed & & \\
\hline Brassia transamazonica D.E.Benn. \& Christenson & MOL & Spirit & & \\
\hline Buesiella suarezii D.E.Benn. \& Christenson & MOL & Spirit & & \\
\hline Campylocentrum huebnerioides D.E.Benn. \& Christenson & MOL & Pressed & & \\
\hline Catasetum adremedium D.E.Benn. \& Christenson & $\mathrm{MOL}$ & $\begin{array}{l}\text { Pressed, part } \\
\text { in spirit }\end{array}$ & & \\
\hline Catasetum cotylicheilum D.E.Benn. \& Christenson & MOL & Spirit & & \\
\hline Catasetum purusense D.E.Benn. \& Christenson & MOL & Pressed & & \\
\hline $\begin{array}{l}\text { Cycnoches cooperi subsp ayacuchoensis D.E. Benn. \& } \\
\text { Christenson }\end{array}$ & MOL & Pressed & & \\
\hline Cycnoches quatuorcristis D.E.Benn. & USM & Pressed & & \\
\hline Cyrtochilum stegasaurum D.E.Benn. \& Christenson & MOL & Spirit & & \\
\hline Dichaea caveroi D.E.Benn. \& Christenson & $\mathrm{MOL}$ & Pressed & & \\
\hline Dichaea delcastilloi D.E.Benn. \& Christenson & MOL & Spirit & & \\
\hline Dichaea longipedunculata D.E.Benn. \& Christenson & MOL & Pressed & & \\
\hline Elleanthus caveroi D.E.Benn. \& Christenson & $\mathrm{MOL}$ & Pressed & MOL & $\begin{array}{l}\text { Pressed }(x 1) \\
\text { Spirit }(x 1)\end{array}$ \\
\hline Epidendrum amplum D.E.Benn. \& Christenson & MOL & Pressed & & \\
\hline Epidendrum bicirrhatum D.E.Benn. \& Christenson & MOL & Pressed & & \\
\hline Epidendrum compressibulbum D.E. Benn. \& Christenson & MOL & $\begin{array}{l}\text { Pressed, part } \\
\text { in spirit }\end{array}$ & & \\
\hline Epidendrum delcastilloi D.E.Benn. \& Christenson & NY & Pressed & & \\
\hline Epidendrum frechetteanum D.E.Benn. \& Christenson & MOL & Spirit & MOL & Spirit (x1) \\
\hline Epidendrum leonii D.E.Benn. \& Christenson & MOL & Spirit & & \\
\hline Epidendrum pseudapaganum D.E.Benn. \& Christenson & MOL & Spirit & & \\
\hline Epidendrum pseudoanceps D.E. Benn. \& Christenson & MOL & Pressed & & \\
\hline Kefersteinia benvenathar D.E.Benn. \& Christenson & MOL & Spirit & & \\
\hline Kefersteinia licethyae D.E.Benn. \& Christenson & $\mathrm{MOL}$ & Spirit & & \\
\hline Kefersteinia villosa D.E.Benn. \& Christenson & NY & Pressed & MOL & Spirit (x1) \\
\hline Lockhartia genegeorgei D.E.Benn. \& Christenson & MOL & Spirit & & \\
\hline Lockhartia lepticaula D.E.Benn. \& Christenson & MOL & Spirit & & \\
\hline Lockhartia schunkei D.E.Benn. \& Christenson & MOL & Spirit & & \\
\hline Lockhartia tuberculata D.E.Benn. \& Christenson & NY & Pressed & $\mathrm{MOL}$ & Spirit (x1) \\
\hline Lycaste diastasia D.E.Benn. \& Oakeley & $\mathrm{MOL}$ & Pressed & & \\
\hline Lycaste jarae D.E.Benn. \& Christenson & NY & Pressed & & \\
\hline Macroclinium aurorae Dodson & MOL & Spirit & & \\
\hline
\end{tabular}


TABle 1. Continues.

\begin{tabular}{|c|c|c|c|c|}
\hline Masdevallia mijahuangae D.E. Benn. & MOL & Pressed & & \\
\hline Maxillaria aurorae D.E.Benn. \& Christenson & MOL & Spirit & & \\
\hline Maxillaria bocazensis D.E.Benn. \& Christenson & MOL & Pressed & & \\
\hline Maxillaria christensonii D.E.Benn. & MOL & Pressed & & \\
\hline Maxillaria frechettei D.E.Benn. \& Christenson & MOL & Spirit & & \\
\hline Maxillaria geckophora D.E.Benn. \& Christenson & MOL & Spirit & & \\
\hline $\begin{array}{l}\text { Maxillaria gigantea subsp. condorensis D.E.Benn. \& } \\
\text { Christenson }\end{array}$ & MOL & Pressed & MOL & $\begin{array}{l}\text { Pressed (x2), } \\
\text { Spirit (x1) }\end{array}$ \\
\hline Maxillaria granditenuis D.E.Benn. \& Christenson & MOL & $\begin{array}{l}\text { Pressed, part } \\
\text { in spirit }\end{array}$ & & \\
\hline Maxillaria hirsutilabia D.E.Benn. \& Christenson & MOL & Pressed & MOL & Spirit (x1) \\
\hline Maxillaria leucopurpurea D.E.Benn. \& Christenson & MOL & Pressed & $\mathrm{MOL}$ & Spirit (x1) \\
\hline Maxillaria liliputana D.E.Benn. \& Christenson & MOL & Spirit & & \\
\hline Maxillaria valleculata D.E.Benn. \& Christenson & MOL & Spirit & & \\
\hline Neodryas acuminata D.E.Benn. \& Christenson & MOL & Spirit & MOL & $\begin{array}{l}\text { Pressed }(x 1), \\
\text { Spirit }(x 1)\end{array}$ \\
\hline Neokoehleria papillosa D.E.Benn. \& Christenson & MOL & Pressed & & \\
\hline Notylia punoensis D.E. Benn. \& Christenson & MOL & Spirit & & \\
\hline Odontoglossum contaypacchaense D.E.Benn. \& Christenson & MOL & Pressed & & \\
\hline Odontoglossum pseudomelanthes D.E. Benn. \& Christenson & MOL & Pressed & MOL & $\begin{array}{l}\text { Pressed }(x 3), \\
\text { Spirit }(x 1)\end{array}$ \\
\hline Oncidium bennettii Christenson & MOL & Spirit & & \\
\hline Oncidium pastorellii Dodson \& D.E.Benn. & MO & Pressed & & \\
\hline Ornithocephalus aurorae D.E.Benn. \& Christenson & MOL & Pressed & MOL & Spirit (x1) \\
\hline Ponthieva collantesii D.E. Benn. \& Christenson & MOL & Pressed & & \\
\hline Rodriguezia satipoana Dodson \& D.E.Benn. & MOL & Pressed & & \\
\hline Sobralia hirta D.E.Benn. \& Christenson & MOL & Spirit & & \\
\hline Sobralia ruparupaensis D.E.Benn. \& Christenson & MOL & Pressed & MOL & Pressed $(x 26)$ \\
\hline Stellilabium peruvianum D.E.Benn. \& Christenson & MOL & Spirit & & \\
\hline Stenia aurorae D.E.Benn. \& Christenson & MOL & Spirit & & \\
\hline Stenia christensonii D.E. Benn. & MOL & Spirit & & \\
\hline Stenia Iuerorum D.E.Benn \& Christenson & MOL & Spirit & & \\
\hline Stenia pustulosa D.E.Benn. \& Christenson & MOL & Spirit & & \\
\hline Stenia wendiae D.E. Benn. \& Christenson & MOL & Spirit & & \\
\hline Stigmatorthos peruviana M.W.Chase \& D.E.Benn. & MOL & Spirit & & \\
\hline Telipogon alegriae D.E.Benn. \& Christenson & MOL & Spirit & MOL & Pressed (x1) \\
\hline Telipogon ariasii Dodson \& D.E.Benn. & MOL & Pressed & & \\
\hline Telipogon collantesii D.E. Benn. \& Christenson & MOL & Spirit & MOL & Pressed $(x 1)$ \\
\hline Telipogon davidsonii D.E. Benn. \& Christenson & NY & Pressed & MOL & Spirit (x1) \\
\hline Telipogon tayacajaensis D.E.Benn. \& Christenson & USM & Pressed & USM & Pressed $(x 1)$ \\
\hline Trichosalpinx pandurata D.E. Benn. \& Christenson & $\mathrm{MOL}$ & Spirit & & \\
\hline Xylobium serratum D.E.Benn. \& Christenson & MOL & Spirit & & \\
\hline
\end{tabular}


TABLE 2. List of type specimens of the Bennett Collection at MOL indicating the type of specimen preparation.

\begin{tabular}{|c|c|c|c|c|c|c|}
\hline \multirow{2}{*}{ Species } & \multicolumn{6}{|c|}{ Type specimen at MOL } \\
\hline & Holotype & Isotype & Paratype & Lectotype & Isolectotype & Neotype \\
\hline Ackermania hajekii D.E. Benn. \& Christenson & Pressed & & & & & \\
\hline Ackermania jarae D.E.Benn. \& Christenson & & Spirit (x1) & & & & \\
\hline Ada peruviana D.E.Benn. \& Christenson & Pressed & & & & & \\
\hline Ada rolandoi D.E. Benn. \& Christenson & & & & Pressed & & \\
\hline Brassia pascoensis D.E.Benn. \& Christenson & & & & Pressed & & \\
\hline Brassia transamazonica D.E.Benn. \& Christenson & & & & Spirit & & \\
\hline Buesiella suarezii D.E.Benn. \& Christenson & & & & Spirit & & \\
\hline $\begin{array}{l}\text { Bulbophyllum machupicchuense D.E.Benn. \& } \\
\text { Christenson }\end{array}$ & Spirit & & & & & \\
\hline $\begin{array}{l}\text { Campylocentrum huebnerioides D.E.Benn. \& } \\
\text { Christenson }\end{array}$ & & & & Pressed & & \\
\hline Catasetum adremedium D.E.Benn. \& Christenson & & & & $\begin{array}{l}\text { Pressed, } \\
\text { part in Spirit }\end{array}$ & & \\
\hline Catasetum cotylicheilum D.E.Benn. \& Christenson & & & & Spirit & & \\
\hline Catasetum purusense D.E.Benn. \& Christenson & & & & Pressed & & \\
\hline Chaubardiella delcastilloi D.E.Benn. \& Christenson & Spirit & & & & & \\
\hline Chaubardiella serrulata D.E.Benn. \& Christenson. & Spirit & & & & & \\
\hline Chondrorhyncha plicata D.E.Benn. \& Christenson & Spirit & & & & & \\
\hline Cycnoches christensonii D.E. Benn. & $\begin{array}{l}\text { Pressed, } \\
\text { part in spirit }\end{array}$ & $\begin{array}{l}\text { Pressed } \\
\quad(\times 3)\end{array}$ & & & & \\
\hline $\begin{array}{l}\text { Cycnoches cooperi subsp ayacuchoensis D.E. Benn. } \\
\& \text { Christenson }\end{array}$ & & & & Pressed & & \\
\hline $\begin{array}{l}\text { Cycnoches farnsworthianum D.E.Benn. \& } \\
\text { Christenson }\end{array}$ & Pressed & & & & & \\
\hline Cyrtochilum mezae D.E.Benn. \& Christenson & Pressed & Spirit (x1) & & & & \\
\hline $\begin{array}{l}\text { Cyrtochilum plurituberculatum D.E.Benn. \& } \\
\text { Christenson }\end{array}$ & $\begin{array}{l}\text { Pressed, } \\
\text { part in spirit }\end{array}$ & & & & & \\
\hline Cyrtochilum stegasaurum D.E.Benn. \& Christenson & & & & Spirit & & \\
\hline Dichaea alcantarae D.E.Benn. \& Christenson & Spirit & & & & & \\
\hline Dichaea caveroi D.E.Benn. \& Christenson & & & & Pressed & & \\
\hline Dichaea delcastilloi D.E.Benn. \& Christenson & & & & Spirit & & \\
\hline Dichaea longipedunculata D.E.Benn. \& Christenson & & & & Pressed & & \\
\hline Dichaea peruviensis D.E.Benn. \& Christenson & Pressed & & & & & \\
\hline Elleanthus caveroi D.E.Benn. \& Christenson & & & & Pressed & $\begin{array}{l}\text { Pressed (x1), } \\
\text { Spirit (x1) }\end{array}$ & \\
\hline Encyclia bennettii Christenson & Spirit & & & & & \\
\hline Epidendrum albifloroides D.E.Benn. \& Christenson & Spirit & & & & & \\
\hline Epidendrum amplum D.E.Benn. \& Christenson & & & & Pressed & & \\
\hline Epidendrum apaganoides D.E.Benn. \& Christenson & Spirit & & & & & \\
\hline
\end{tabular}


TABle 2. Continues.

\begin{tabular}{|c|c|c|c|c|c|c|}
\hline Epidendrum azulense D.E.Benn. \& Christenson & $\begin{array}{l}\text { Pressed, } \\
\text { part in spirit }\end{array}$ & & & & & \\
\hline Epidendrum bicirrhatum D.E.Benn. \& Christenson & & & & Pressed & & \\
\hline Epidendrum bidens D.E.Benn. \& Christenson & Pressed & & & & & \\
\hline Epidendrum burtonii D.E.Benn. \& Christenson & Pressed & & & & & \\
\hline Epidendrum caveroi D.E.Benn. \& Christenson & $\begin{array}{l}\text { Pressed, } \\
\text { part in spirit }\end{array}$ & & & & & \\
\hline $\begin{array}{l}\text { Epidendrum compressibulbum D.E. Benn. \& } \\
\text { Christenson }\end{array}$ & & & & $\begin{array}{l}\text { Pressed, } \\
\text { part in Spirit }\end{array}$ & & \\
\hline $\begin{array}{l}\text { Epidendrum cryptotropis Hágsater, Collantes \& } \\
\text { E.Santiago }\end{array}$ & Pressed & & & & & \\
\hline $\begin{array}{l}\text { Epidendrum dialychilum subsp. peruvianum } \\
\text { D.E.Benn. \& Christenson }\end{array}$ & & Spirit $(x 1)$ & & & & \\
\hline Epidendrum frechetteanum D.E.Benn. \& Christenson & & & & Spirit & Spirit (x1) & \\
\hline Epidendrum fujimorianum D.E.Benn. \& Christenson & $\begin{array}{l}\text { Pressed, } \\
\text { part in spirit }\end{array}$ & & & & & \\
\hline Epidendrum fuscum Schltr. & & & & & & Spirit \\
\hline Epidendrum jarae D.E.Benn. \& Christenson & Pressed & Spirit (x2) & & & & \\
\hline Epidendrum laxicaule D.E.Benn. \& Christenson & & Spirit (x2) & & & & \\
\hline Epidendrum leonii D.E.Benn. \& Christenson & & & & Spirit & & \\
\hline Epidendrum Ilactapataense D.E.Benn. \& Christenson & Pressed & & & & & \\
\hline $\begin{array}{l}\text { Epidendrum microcattleyioides D.E.Benn. \& } \\
\text { Christenson }\end{array}$ & Spirit & & & & & \\
\hline $\begin{array}{l}\text { Epidendrum pseudapaganum D.E.Benn. \& } \\
\text { Christenson }\end{array}$ & & & & Spirit & & \\
\hline $\begin{array}{l}\text { Epidendrum pseudoalbiflorum D.E.Benn. \& } \\
\text { Christenson }\end{array}$ & $\begin{array}{l}\text { Pressed, } \\
\text { part in spirit }\end{array}$ & & & & & \\
\hline $\begin{array}{l}\text { Epidendrum pseudoanceps D.E. Benn. \& } \\
\text { Christenson }\end{array}$ & & & & Pressed & & \\
\hline $\begin{array}{l}\text { Epidendrum pseudopolystachyum D.E.Benn. \& } \\
\text { Christenson }\end{array}$ & Spirit & & & & & \\
\hline Epidendrum ruizlarreanum D.E.Benn. \& Christenson & Spirit & & & & & \\
\hline $\begin{array}{l}\text { Epidendrum schizoclinandrium D.E.Benn. \& } \\
\text { Christenson }\end{array}$ & Spirit & & & & & \\
\hline $\begin{array}{l}\text { Epidendrum semiteretifolium D.E.Benn. \& } \\
\text { Christenson }\end{array}$ & Pressed & Spirit (x1) & & & & \\
\hline Epidendrum septumspinae D.E.Benn. \& Christenson & $\begin{array}{l}\text { Pressed, } \\
\text { part in spirit }\end{array}$ & & & & & \\
\hline Epidendrum uncinatum D.E.Benn. \& Christenson & Spirit & & $\begin{array}{l}\text { Pressed, } \\
\text { part in } \\
\text { spirit (x1) }\end{array}$ & & & \\
\hline Galeottia peruviana D.E.Benn. \& Christenson & Pressed & & & & & \\
\hline Gongora erecta Whitten \& D.E.Benn. & & $\begin{array}{l}\text { Pressed } \\
\quad(\mathrm{x} 1)\end{array}$ & & & & \\
\hline Ida hajekii D.E.Benn. \& Oakeley & Pressed & $\begin{array}{l}\text { Pressed } \\
\text { (x1), Spirit } \\
\text { (x1) }\end{array}$ & & & & \\
\hline Kefersteinia aurorae D.E.Benn. \& Christenson & & Spirit (x1) & Spirit (x1) & & & \\
\hline Kefersteinia benvenathar D.E.Benn. \& Christenson & & & & Spirit & & \\
\hline Kefersteinia candida D.E.Benn. \& Christenson & & & Spirit (x1) & & & \\
\hline
\end{tabular}


TABLE 2. Continues.

\begin{tabular}{|c|c|c|c|c|}
\hline Kefersteinia licethyae D.E.Benn. \& Christenson & & & Spirit & \\
\hline Kefersteinia villenae D.E.Benn. \& Christenson & & Spirit (x2) & & \\
\hline Kefersteinia villosa D.E.Benn. \& Christenson & & & & Spirit (x1) \\
\hline Lepanthes caveroi D.E.Benn. \& Christenson & Pressed & & & \\
\hline $\begin{array}{l}\text { Lepanthes leonii D.E.Benn. \& Christenson. (no } \\
\text { Lepanthes leonii C.Schweinf.) }\end{array}$ & Pressed & & & \\
\hline $\begin{array}{l}\text { Lepanthes oxapampaensis D.E. Benn. \& } \\
\text { Christenson }\end{array}$ & Pressed & & & \\
\hline Lockhartia genegeorgei D.E.Benn. \& Christenson & & & Spirit & \\
\hline Lockhartia lepticaula D.E.Benn. \& Christenson & & & Spirit & \\
\hline Lockhartia schunkei D.E.Benn. \& Christenson & & & Spirit & \\
\hline Lockhartia tuberculata D.E.Benn. \& Christenson & & & & Spirit $(x 1)$ \\
\hline Lycaste diastasia D.E.Benn. \& Oakeley & & & Pressed & \\
\hline Macroclinium aurorae Dodson & & & Spirit & \\
\hline Macroclinium christensonii D.E. Benn. & & Spirit (x1) & & \\
\hline Macroclinium villenarum D.E.Benn. & Spirit & & & \\
\hline Masdevallia mijahuangae D.E. Benn. & & & Pressed & \\
\hline $\begin{array}{l}\text { Masdevallia oxapampaensis D.E. Benn. \& } \\
\text { Christenson }\end{array}$ & Spirit & & & \\
\hline Maxillaria aurorae D.E.Benn. \& Christenson & & & Spirit & \\
\hline Maxillaria azulensis D.E.Benn. \& Christenson & Pressed & & & \\
\hline Maxillaria bennettii Christenson & $\begin{array}{l}\text { Pressed, } \\
\text { part in spirit }\end{array}$ & & & \\
\hline Maxillaria bocazensis D.E.Benn. \& Christenson & & & Pressed & \\
\hline Maxillaria burtonii D.E.Benn. \& Christenson & Spirit & & & \\
\hline Maxillaria caveroi D.E.Benn. \& Christenson & & $\begin{array}{l}\text { Pressed } \\
(\mathrm{x} 2), \\
\text { Spirit (x1) }\end{array}$ & & \\
\hline Maxillaria christensonii D.E.Benn. & & & Pressed & \\
\hline Maxillaria edwardsii D.E.Benn. \& Christenson & Spirit & & & \\
\hline Maxillaria foetida D.E.Benn. \& Christenson & Spirit & & & \\
\hline Maxillaria frechettei D.E.Benn. \& Christenson & & & Spirit & \\
\hline Maxillaria garayi D.E.Benn \& Christenson & Spirit & & & \\
\hline Maxillaria geckophora D.E.Benn. \& Christenson & & & Spirit & \\
\hline $\begin{array}{l}\text { Maxillaria gigantea subsp. condorensis D.E.Benn. \& } \\
\text { Christenson }\end{array}$ & & & Pressed & $\begin{array}{l}\text { Pressed (x2), } \\
\text { Spirit (x1) }\end{array}$ \\
\hline Maxillaria granditenuis D.E.Benn. \& Christenson & & & $\begin{array}{l}\text { Pressed, } \\
\text { part in } \\
\text { Spirit }\end{array}$ & \\
\hline Maxillaria hirsutilabia D.E.Benn. \& Christenson & & & Pressed & Spirit (x1) \\
\hline Maxillaria huanucoensis D.E.Benn. \& Christenson & Spirit & & & \\
\hline Maxillaria leucopurpurea D.E.Benn. \& Christenson & & & Pressed & Spirit (x1) \\
\hline
\end{tabular}

LANKESTERIANA 14(1), April 2014. (C) Universidad de Costa Rica, 2014. 
TABLE 2. Continues.

\begin{tabular}{|c|c|c|c|c|}
\hline Maxillaria liliputana D.E.Benn. \& Christenson & & & Spirit & \\
\hline Maxillaria machinazensis D.E.Benn. \& Christenson & & $\begin{array}{l}\text { Pressed } \\
\text { (x3), Spirit } \\
\text { (x1) }\end{array}$ & & \\
\hline Maxillaria microiridifolia D.E.Benn. \& Christenson & Pressed & & & \\
\hline Maxillaria minutiflora D.E.Benn. \& Christenson & $\begin{array}{l}\text { Pressed, } \\
\text { part in spirit }\end{array}$ & & & \\
\hline Maxillaria purpureolabia D.E.Benn. \& Christenson & Spirit & & & \\
\hline Maxillaria pyhalae D.E.Benn. \& Christenson & Spirit & $\begin{array}{l}\text { Pressed } \\
(\times 1)\end{array}$ & & \\
\hline Maxillaria scandens D.E.Benn. \& Christenson & & $\begin{array}{l}\text { Pressed } \\
\quad(\mathrm{x} 1)\end{array}$ & & \\
\hline $\begin{array}{l}\text { Maxillaria trigona subsp. amaroensis D.E.Benn. \& } \\
\text { Christenson }\end{array}$ & Spirit & & & \\
\hline Maxillaria trilobulata D.E.Benn. \& Christenson & Spirit & & & \\
\hline Maxillaria tuerosii D.E.Benn. \& Christenson & $\begin{array}{l}\text { Pressed, } \\
\text { part in spirit }\end{array}$ & & & \\
\hline Maxillaria valleculata D.E.Benn. \& Christenson & & & Spirit & \\
\hline Mesadenella variegata D.E. Benn. \& Christenson & Spirit & & & \\
\hline Mormolyca aurorae D.E.Benn. \& Christenson & Spirit & & & \\
\hline Neodryas acuminata D.E.Benn. \& Christenson & & & Spirit & $\begin{array}{l}\text { Pressed (x1) } \\
\text { Spirit (x1) }\end{array}$ \\
\hline Neodryas Ilanachagaensis D.E. Benn. \& Christenson & Spirit & & & \\
\hline Neokoehleria delcastilloi D.E.Benn \& Christenson & Pressed & & & \\
\hline Neokoehleria papillosa D.E.Benn. \& Christenson & & & Pressed & \\
\hline Notylia punoensis D.E. Benn. \& Christenson & & & Spirit & \\
\hline $\begin{array}{l}\text { Odontoglossum contaypacchaense D.E.Benn. \& } \\
\text { Christenson }\end{array}$ & & & Pressed & \\
\hline $\begin{array}{l}\text { Odontoglossum llanachagaense D.E. Benn. \& } \\
\text { Christenson }\end{array}$ & Spirit & & & \\
\hline $\begin{array}{l}\text { Odontoglossum machupicchuense D.E.Benn. \& } \\
\text { Christenson }\end{array}$ & Spirit & & & \\
\hline $\begin{array}{l}\text { Odontoglossum pseudomelanthes D.E. Benn. \& } \\
\text { Christenson }\end{array}$ & & & Pressed & $\begin{array}{l}\text { Pressed (x3) } \\
\text { Spirit (x1) }\end{array}$ \\
\hline $\begin{array}{l}\text { Odontoglossum rubrocallosum D.E.Benn. \& } \\
\text { Christenson }\end{array}$ & Pressed & & & \\
\hline Oncidium aurorae D.E. Benn. \& Christenson & & $\begin{array}{l}\text { Pressed } \\
(\mathrm{x} 1)\end{array}$ & & \\
\hline Oncidium ayabacanum D.E. Benn. \& Christenson & Spirit & & & \\
\hline Oncidium bennettii Christenson & & & Spirit & \\
\hline Oncidium exasperatoides D.E.Benn. \& Christenson & Pressed & & & \\
\hline Oncidium miradorense D.E. Benn. \& Christenson & Pressed & & & \\
\hline Ornithocephalus aurorae D.E.Benn. \& Christenson & & & Pressed & Spirit (x1) \\
\hline Ornithocephalus caveroi D.E.Benn. \& Christenson & Spirit & & & \\
\hline Fernandezia pastorelliae D. Trujillo. sp. nov. & Pressed & & & \\
\hline
\end{tabular}


TABLE 2. Continues.

\begin{tabular}{|c|c|c|c|c|c|c|}
\hline Pachyphyllum ecallosum D.E.Benn. \& Christenson & $\begin{array}{l}\text { Pressed, } \\
\text { part in spirit }\end{array}$ & & & & & \\
\hline Ponthieva collantesii D.E. Benn. \& Christenson & & & & Pressed & & \\
\hline Prosthechea hajekii D.E.Benn. \& Christenson & $\begin{array}{l}\text { Pressed, } \\
\text { part in spirit }\end{array}$ & & & & & \\
\hline Rodriguezia delcastilloi D.E. Benn. \& Christenson & & Spirit (x1) & & & & \\
\hline Rodriguezia satipoana Dodson \& D.E.Benn. & & & & Pressed & & \\
\hline Rusbyella suarezii D.E.Benn. \& Christenson & Spirit & & & & & \\
\hline Scelochilus campoverdei D.E.Benn. \& Christenson & & Spirit (x1) & & & & \\
\hline $\begin{array}{l}\text { Scelochilus crucicornibus Senghas, D.E.Benn. \& } \\
\text { Christenson }\end{array}$ & Pressed & & & & & \\
\hline Scelochilus delcastilloi D.E.Benn. \& Christenson & Spirit & & Spirit $(x 1)$ & & & \\
\hline Sobralia altissima D.E.Benn. \& Christenson & Pressed & $\begin{array}{l}\text { Pressed } \\
(\times 1)\end{array}$ & & & & \\
\hline Sobralia hirta D.E.Benn. \& Christenson & & & & Spirit & & \\
\hline Sobralia ruparupaensis D.E.Benn. \& Christenson & & & & Pressed & $\begin{array}{l}\text { Pressed } \\
(\mathrm{x} 26)\end{array}$ & \\
\hline Sobralia withneri D.E.Benn. \& Christenson & Spirit & & & & & \\
\hline Sphyrastylis garayi D.E.Benn. \& Christenson & Pressed & Spirit (x1) & & & & \\
\hline Stellilabium peruvianum D.E.Benn. \& Christenson & & & & Spirit & & \\
\hline $\begin{array}{l}\text { Stellilabium pseudobulbosum D.E.Benn. \& } \\
\text { Christenson }\end{array}$ & Spirit & & & & & \\
\hline Stenia aurorae D.E.Benn. \& Christenson & & & & Spirit & & \\
\hline Stenia christensonii D.E. Benn. & & & & Spirit & & \\
\hline Stenia jarae D.E.Benn. & Pressed & & Spirit (x1) & & & \\
\hline Stenia lillianae Jenny ex D.E.Benn. \& Christenson & & & Spirit (x1) & & & \\
\hline Stenia Iuerorum D.E.Benn. \& Christenson & & & & Spirit & & \\
\hline Stenia pastorellii D.E.Benn. & Pressed & & & & & \\
\hline Stenia pustulosa D.E.Benn. \& Christenson & & & & Spirit & & \\
\hline Stenia wendiae D.E. Benn. \& Christenson & & & & Spirit & & \\
\hline Stigmatorthos peruviana M.W.Chase \& D.E.Benn. & & & & Spirit & & \\
\hline Telipogon alegriae D.E.Benn. \& Christenson & & & & Spirit & Pressed $(x 1)$ & \\
\hline Telipogon antonietae D.E.Benn. \& Ric.Fernández & Spirit & & & & & \\
\hline Telipogon ariasii Dodson \& D.E.Benn. & & & & Pressed & & \\
\hline Telipogon atropurpurea D.E.Benn. \& Ric.Fernández & Pressed & & & & & \\
\hline Telipogon auriculatus D.E.Benn. \& Christenson & Pressed & Spirit $(x 1)$ & & & & \\
\hline Telipogon campoverdei D.E.Benn. \& Ric.Fernández & Pressed & & & & & \\
\hline Telipogon collantesii D.E. Benn. \& Christenson & & & & Spirit & Pressed $(\mathrm{x} 1)$ & \\
\hline Telipogon davidsonii D.E. Benn. \& Christenson & & & & & Spirit (x1) & \\
\hline Telipogon genegeorgei D.E. Benn. \& Ric.Fernández & Pressed & & $\begin{array}{l}\text { Pressed } \\
\text { (x1), Spirit } \\
\text { (x2) }\end{array}$ & & & \\
\hline
\end{tabular}


TABle 2. Continues.

\begin{tabular}{l|c|c|c|c|c|c}
\hline Telipogon sayakoae D.E.Benn. \& Christenson & Spirit & & & & \\
\hline Telipogon suarezii D.E.Benn. \& Christenson & Pressed & Spirit (x1) & & & & \\
\hline Trichoceros dombeyi D.E.Benn. \& Christenson & & & $?$ & & & \\
\hline Trichoceros hajekiorum D.E.Benn. \& Christenson & $\begin{array}{c}\text { Pressed. } \\
\text { part in spirit }\end{array}$ & & & & & \\
\hline Trichopilia undulatissima D.E.Benn. \& Christenson & & Spirit (x1) & & & & \\
\hline Trichosalpinx dentialae D.E.Benn. \& Christenson & Pressed & & & & \\
\hline Trichosalpinx pandurata D.E. Benn. \& Christenson & & & & Spirit & & \\
\hline Xylobium serratum D.E.Benn. \& Christensona & & & & Spirit & & \\
\hline Zootrophion leonii D.E.Benn. \& Christenson & Pressed & & & & \\
\hline Total & 85 & 35 & 9 & 63 & 46 & 1 \\
\hline
\end{tabular}

Acknowledgements. To Carlos Reynel and Jose Luis Marcelo for the facilities provided to work with the Bennett Collection at MOL. To the curators of USM for the facilities provided to check the orchid collection. To the curator of AMES, FLAS, K, NY, and SEL for their help looking for the type material in their institutions. To Diana Bennett and Richard Bennett for their help in looking for David Bennett's notes and records. To John H Wiersema and Blanca León for their valuable nomenclature guidance. To Phillip Cribb, Günter Gerlach, and Eric Hágsater for their comments on the paper. To Gino Mondragon and Miriam Rivera for their collaboration in mounting the Bennett's pressed specimens.

\section{LITERATURE CITED}

Archila, F. 2002. Addenda et corrigenda para Sudamerlycaste Archila. Revista Guatemal. 5: 77-82.

Archila, F. 2003. Addenda et corrigenda para Sudamerlycaste Archila (Orchidaceae) parte 2.. Revista Guatemal. 6: 1-6 Bennett, D.E. 1992. New orchid species from Peru. Lindleyana 7: 80-97.

Bennett, D.E. \& E.A. Christenson. 1993 Icones Orchidacearum Peruviarum, pl. 1-200.

Bennett, D.E. \& E.A. Christenson. 1994a. New species and new combinations in Peruvian Orchidaceae. Brittonia: 46, 24-53.

Bennett, D.E. \& E.A. Christenson. 1994b. New species of Peruvian Orchidaceae II. Brittonia 46: 228-259.

Bennett, D.E. \& E.A. Christenson. 1995a New species of Peruvian Orchidaceae III. Brittonia 47: 182-209.

Bennett, D.E. \& E.A. Christenson. 1995b Icones Orchidacearum Peruviarum. pl. 201-400.

Bennett, D.E. \& E.A. Christenson. 1998a. New species of Peruvian Orchidaceae, IV. Brittonia 50: 186-191.

Bennett, D.E. \& E.A. Christenson. 1998b. New species of
Peruvian Orchidaceae, V. Lindleyana 13: 31-56.

Bennett, D.E. \& E.A. Christenson. 1998c New species of Peruvian Orchidaceae, VI. Lindleyana 13: 64-96.

Bennett, D.E. \& E.A. Christenson. 1998d. Icones Orchidacearum Peruviarum, pl. 401-600.

Bennett, D.E. \& E.A. Christenson. 1999. Sobralia altissima. Orchids 68: 1112-1113.

Bennett, D.E. \& E.A. Christenson. 2001. Icones Orchidacearum Peruviarum, pl. 601-800.

Bennett, D.E. \& E.A. Christenson. 2009. Nine new species and one new name in Maxillaria (Orchidaceae). Phytotaxa 1: 21-36.

Blanco, M.A., 2013. New combinations and synonyms in the Maxillarinae (Orchidaceae). Selbyana 31: 52-59.

Chase, M.W. \& D.E. Bennett. 1993. Stigmatorthos peruviana-A new genus and species in the Scelochilus alliance (Orchidaceae: Oncidiinae). 8: 3-8.

Chase, M. W., N. H. Williams, K. M. Neubig \& W. M. Whitten. 2008. Taxonomic transfers in oncidiinae to accord with Genera orchidacearum, vol. 5. Lindleyana in Orchids (West Palm Beach) 77.(12): 20-31.

Chase, M.W \& W.M. Whitten. 2011. Further taxonomic transfers in Oncidiinae (Orchidaceae). Phytotaxa 20: 26-32.

Collantes, B. \& E. Hágsater. 2013. Epidendrum frechetteanum. pl.1429. in: E. Hágsater \& L. Sánchez S. (eds.) Icones Orchidacearum. Fasc. 14. The Genus Epidendrum. Part 10. Herbario AMO. Mexico D.F.

Christenson, E.A., 2008. A synopsis of Pachyphyllum (Orchidaceae). J. Bot. Res. Inst. Texas 2: 285-289.

Christenson, E.A. 2009. Four new species of Maxillaria from Colombia and Peru and two less from Ecuador. Richardiana: 9: 49-62.

Dalström, S. 2001. A synopsis of the genus Cyrtochilum (Oncidiinae): Taxonomic reevaluation and new 
combinations. Lindleyana 16: 56-80.

Dalström, S. 2002. A synopsis of the genus Cyrtochilum (Orchidaceae; Oncidiinae): Errata and New combinations. Lindleyana 17: 91-92.

Dalström, S. 2012. New combinations in Odontoglossum (Orchidaceae: Oncidiinae) and a solution to a taxonomic conundrum. Lankesteriana 12: 53-60.

Dalström, S. \& S. Ruíz-Pérez. 2012. Three new smallflowered Cyrtochilum species (Orchidaceae: Oncidiinae) from Colombia and Peru, and one new combination. Lankesteriana 12: 147-153.

Greuter, W., et al. (eds). 2000. International Code of Botanical Nomenclature (St Louis Code) adopted by the Sixteenth International Botanical Congress, St Louis, Missouri, July-August 1999. Regnum Vegetabile 138.

Hágsater, E \& C.H. Dodson. 2001. Epidendrum rhopalostele. pl. 481 in: E. Hágsater \& L. Sánchez S. (eds.) Icones Orchidacearum. Fasc. 4. The Genus Epidendrum. Part 3. Herbario AMO. Mexico D.F.

Hágsater, E. 2006. Epidendrum fujimorianum. pl. 834 in: E. Hágsater \& L. Sánchez S. (eds.) Icones Orchidacearum. Fasc. 8. The Genus Epidendrum. Part 5. Herbario AMO. Mexico D.F.

Hágsater, E. 2009. Epidendrum forcipatum. pl.1243 in: E. Hágsater \& L. Sánchez S. (eds.), Icones Orchidacearum. Fasc. 12. The Genus Epidendrum. Part 8. Herbario AMO. Mexico D.F.
Hágsater, E., B. Collantes \& E. Santiago. 2013. Epidendrum cryptotropis. pl 1420 in: E. Hágsater \& L. Sánchez S. (eds.) Icones Orchidacearum. Fasc. 14. The Genus Epidendrum. Part 10. Herbario AMO. Mexico D.F

Hills, H.G. 2012. Taxonomic revision of Dressleria (Orchidaceae, Catasetinae). Phytoneuron 48:1-28.

Luer, C. A. 2002. Icones Pleurothallidinarum. XXIII. Systematics of Masdevallia, part four. M. subgen. Masdevallia, section Masdevallia. subsection Caudatae subsection Oscilantes, subsection Saltatrices. Monogr. Syst. Bot. Missouri Bot. Gard. 87: 781-1047.

McNeill, J. et al. (eds.). 2006. International Code of Botanical Nomenclature (Vienna code), adopted by 17th IBC, Vienna, 2005. Regnum Vegetabile 146.

McNeill, J. et al. (eds.). 2012. International Code of Botanical Nomenclature (Melbourne code), adopted by 18th IBC, Melbourne, 2011. Regnum Vegetabile 154.

Oakeley, H.F. 2003. Infrageneric classification of Ida and the description of a new hybrid genus Lycida Oakeley. Orchid Digest 67: 11-29.

Oakeley, H.F. 2008. Lycaste, Ida and Anguloa. The essential guide: $1-445$.

Roque, J \& B..León. 2007. Orchidaceae endémicas del Perú. Rev. peru. biol. 13: 759-878.

Senghas, K., D.E. Bennett \& E.A. Christenson. 1998. Validating a Peruvian Scelochilus (Orchidaceae: Oncidiinae). Brittonia 50: 183-185. 


\section{ERRATA CORRIGE}

\section{Vanilla rivasii (Orchidaceae), a new species from the Colombian Pacific region}

Francisco Molineros-Hurtado, Robert Tulio González Mina, Nicola S. Flanagan and J. TUPAC OTERO

A previous, working version of the illustration of of LANKESTERIANA 13(3). The correct illustration is Vanilla rivasii was inadvertently printed on page 355 given here.

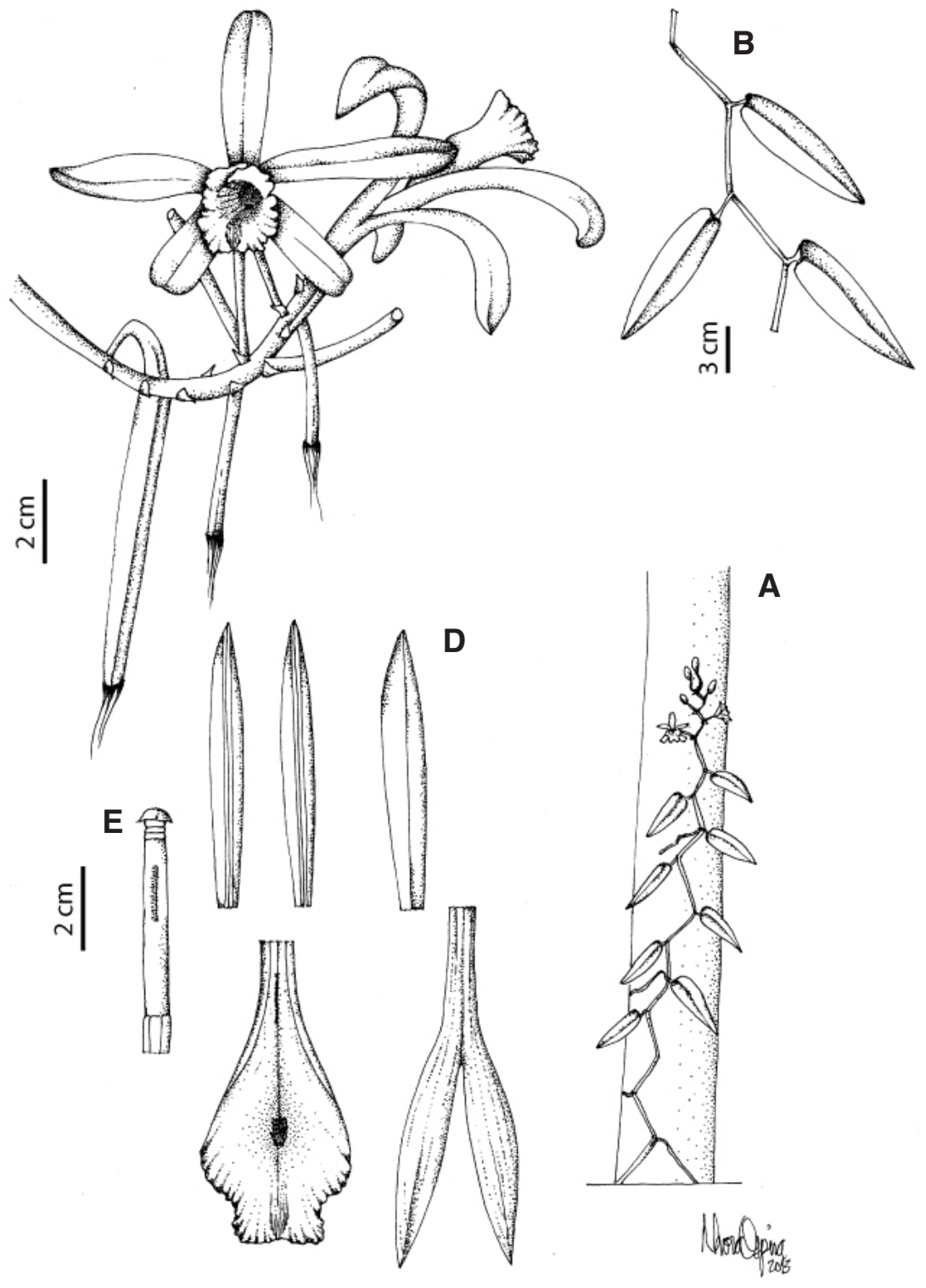

FIgURE 1. Vanilla rivasii Molineros, Rob.González, Flanagan \& J.T.Otero. A - Habit. B - Portion of the stem with leaves. C-Inflorescence with flowers and fruits. D-Dissected perianth. E-Column, ventral view. Drawing from the holotype by Nhora Helena Ospina Calderón. 